\title{
SIG GALILEO FINAL CONVERTER \\ TECHNICAL SUMMARY REPORT
}

MMM-2864-0055

MAY 1979

by

\section{J. D. HINDERMAN}

PROGRAM MANAGER

3M COMPANY

\author{
PREPARED FOR POWER SYSTEMS BRANCH \\ ADVANCED SYSTEMS AND MATERIALS \\ PRODUCTION DIVISION, DEPARTMENT OF ENERGY \\ UNDER DoE CONTRACT DE-AC01-78ET-33008
}

\footnotetext{
MINNESOTA MINING AND MANUFACTURING COMPANY ELECTRICAL PRODUCTS GROUP INDUSTRIAL ELECTRICAL PRODUCTS DIVISION ST. PAUL, MINNESOTA 55101
} 


\section{DISCLAIMER}

This report was prepared as an account of work sponsored by an agency of the United States Government. Neither the United States Government nor any agency Thereof, nor any of their employees, makes any warranty, express or implied, or assumes any legal liability or responsibility for the accuracy, completeness, or usefulness of any information, apparatus, product, or process disclosed, or represents that its use would not infringe privately owned rights. Reference herein to any specific commercial product, process, or service by trade name, trademark, manufacturer, or otherwise does not necessarily constitute or imply its endorsement, recommendation, or favoring by the United States Government or any agency thereof. The views and opinions of authors expressed herein do not necessarily state or reflect those of the United States Government or any agency thereof. 


\section{DISCLAIMER}

Portions of this document may be illegible in electronic image products. Images are produced from the best available original document. 


\section{LEGAL NOTICE}

This report was prepared as an account of Government sponsored work. Neither the United States, nor DoE, nor any person acting on behalf of DoE:

a. Makes any warranty or representation, expressed or implied, with respect to the accuracy, completeness, or usefulness of the information contained in this report, or that the use of any information, apparatus, method, or process disclosed in this report may not infringe privately owned rights; or

b. Assumes any liabilities with respect to the use of, or for damages resulting from the use of, any information, apparatus, method, or process disclosed in this report.

As used in the above, "person acting on behalf of DoE" includes any employee or contractor of DoE, or employee of such contractor, to the extent that such employee or contractor of DoE, or employee of such contractor prepares, disseminates, or provides access to, any information pursuant to his employment or contract with DoE, or his employment with such contractor. 


\section{TABLE OF CONTENTS}

PAGE

INTRODUCTION

I. ENGINEERING DESIGN

A. Converter Configuration

I-1

I-2

B. Converter Design Activity

I-20

C. Design Documentation

$1-26$

D. Attachments to Section I

II. DESIGN ANALYSIS

II-1

A. Couple Performance Program $\quad 11-1$

B. Effects of Point Contacts on the Electrical Behavior of TPM-217 II-17

C. Heat Flow Through a Converter

D. Characterization of Dynamic Response

II-17

$11-21$

E. Thermal Expansion Calculations

$11-21$

F. Applied Stress Variations

$11-21$

G. N-Leg Thermal Stress Analysis

$11-32$

$\mathrm{H}$. Calculation of the Maximum Stress Level in the POCO Hot Ring II-32

III. SYSTEM TESTING

III-1

A. Spring Load Relaxation III-1

B. Converter to Housing Interfacial $\Delta T \quad$ III-2

C. Cold End Hardware Thermal Resistance III-2

D. Chemical Compatibility of Nickel Hot Junction Electrodes with GdSe III-2

E. POCO Graphite Adsorption/Desorption Tests $\quad$ III-10

F. Storage Conditions: Sputtered GdSe $\quad$ III-12

G. Testing to Obtain Reliability Data Base III-14

H. Attachment to Section III III-16

IV. MANUFACTURING IV-1

A. Hot Frame and Heater Blocks IV-1.

B. Ceramic Pins IV-1

C. Platinum Strips IV-1

D. Hot Current Straps - Gimbals IV-2

E. Platinum and Nickel Foil Discs IV-2

F. Support of Leg Manufacture IV-2

G. Cold End Hardware IV-3

H. Twist Locks IV-4

I. Cold Frame Segment IV-4

J. Copper Foil Flexible Followers/Current Straps IV-4 
TABLE OF CONTENTS (Continued)

K. Spring Retainer Buttons IV -5

L. BeO Discs IV-5

M. Cold Current Strap Assembly IV-5

N. Cold Frame Segment and Flexible Follower Solder Sub-Assembly IV-5

O. Investigation of Ultrasonic Welding of Cold End Hardware IV-6

P. Final Assembly IV-6

Q. Equipment IV-6

R. Special Processing and Shipping Containers IV-6

V. QUALITY ENGINEERING AND CONTROL $\quad$ V-1

A. Quality Assurance $\quad$ V-1

B. Configuration Management $\quad \mathrm{V}-1$

C. DoE Acceptance V-1

D. Non-Destructive Testing V-1

VI. RELIABILITY VI-1

A. Reliability VI-1

$\begin{array}{ll}\text { B. Attachment to Section VI } & \text { VI-6 }\end{array}$ 


\section{INTRODUCTION}

This report summarizes significant events, activities and achievements on the SIG/Galileo Converter Program at 3M Company during the period June 1, 1978 through May 15, 1979 under Department of Energy Contract DE-AC01-78EG-33008. A stop work order was received from DoE on January 29, 1979 and all subsequent work and close out activities targeted for completion by May 15, 1979.

The report is primarily concerned with the work performed for DoE on converter development and fabrication for the NASA Galileo Jupiter mission as a DoE prime contractor with interface primarily with Teledyne Energy Systems. The activities reported on were directed toward design, analysis and testing of modules and converters SN-1 thru SN-7 and attendant Quality Control and Reliability effort. Although assembly and testing of SN-1 was not accomplished due to the stop work order, the design was virtually completed and a significant amount of subcontracting and manufacturing of both module and converter components was underway. These subcontracting and manufacturing activities were selectively closed down depending upon degree of completion and material or hardware potential usage in the Technology Program (Contract EY-76-C-02-2331).

The primary interface during the program was with Teledyne Energy Systems (TES) for design and assembly of the thermoelectric converter into the generator housing provided by the government as GFE (from TES). Other efforts dealt with test module design and fabrication, quality control and reliability.

The stop work order was received before a detailed program plan was completed. After the receipt of the stop work order a proposal was prepared to reflect the modified statement-of-work associated with the close-out-effort (Ref. "Proposal to Close-Out the Contract DE-AC01-78-ET-33008 (Formerly No. ET-78-C-01-7864)", No. 2864-0049, March 8, 1979). This report therefore serves as both the Final Technical Report and the Program Plan for the SIG/Galileo Converter Program (Contract No. DE-AC01-78ET-33008). 


\section{ENGINEERING DESIGN}

As described in the SIG/Galileo Statement of Work (Section 3.1), the Design Group is responsible for module, converter, and test equipment design. The majority of the work is centered around the design of the modules and converter, and the interface developments with Teledyne Energy Systems (TES).

Section A describes, in detail, the component configurations developed and proposed for the SN-1 converter. ${ }^{1}$ This converter was the "Flight Design" with the possible exception of N-leg improvements and a 'cold frame - housing interface' processing change. Included at the end of the converter description is the status of the design at the time of the 'stop work order'.

In Section B, the activities performed to accomplish the design goals are described as they occurred.

Section $C$ lists all pertinent documentation which was developed and issued relating to the design of the converter. This includes drawings, specifications, procedures and analysis.

Operating requirements for the $\mathrm{SN}-1$ converter are given in Table I-1.

TABLE I-1

\section{OBJECTIVES AND REQUIREMENTS FOR SN-1 CONVERTER}

- $\quad T_{H} / T_{C}=860 / 160^{\circ} \mathrm{C}$

- $\quad$ Voltage $=30$ volts

- N-Leg Material Resistance - $22.9 \mathrm{~m} \Omega$

- $22 \mathrm{~m} \Omega$ Contact Resistance on $\mathrm{N}$ - and P-Legs

- $\quad$ Nominal Power Output $(B O L)=193 \mathrm{~W}(\mathrm{e})$

- Designed to Withstand and Launch Loads Although Vibration Test Not Planned

- $\quad$ Converter Weight $=16.0 \mathrm{lbs}$.

- Extraneous Resistance $=12-1 / 2 \%$

- Cold End Thermal Resistance $=7^{\circ} \mathrm{C} /$ watt

1) The design requirements are listed in Table $\mathrm{I}-1$. 


\section{A. CONVERTER CONFIGURATION}

\section{M/TES Interface}

Figures I-1 and I-2 show the proposed SIG/Galileo RTG package that was to be supplied by Teledyne Energy Systems (TES). 3M's interface with TES lies in the power section of the generator, shown in Figure 1-3. $3 \mathrm{M}$ was responsible for supplying the two converter ring assemblies. In addition, $3 \mathrm{M}$ would handle the installation of the two converter ring assemblies, the center multi-foil sleeve assembly (TES), center section insulation, and the initial instrumentation wiring into the housing supplied by TES.

A brief version of $3 \mathrm{M}^{\prime} \mathrm{s}$ installation procedure follows (see Figure $1-3$ ):

1. $3 M$ receives aluminum housing from TES

2. Position converter ring No. 2 into housing. Remove assembly tooling.

3. Slide center multi-foil sleeve assembly (see Figure 1-4) (Supplied by TES) into position next to converter ring No. 2.

4. Insert converter ring No. 1 into position. Remove assembly tooling.

Assure that locating pins between multi-foil sleeve and converter rings are in position (see Figure 1-5)

5. Make all required power and instrumentation connections and route wires.

6. Stuff fiberfrax insulation between converter ring No. 1 and center multi-foil sleeve assembly as shown in Figure 1-5. Slide retainer tab into position.

7. Transfer secured unit back to TES following $3 \mathrm{M}$ testing.

Activities involving interface between $3 \mathrm{M}$ and TES are covered in Section B.

The $3 \mathrm{M}$ thermoelectric converter ring assembly is shown in Figure 1-6. It consists of a POCO support ring with 28 segment assemblies located around its periphery. Two converter rings are wired in series within the TES housing (see Figure 1-7.) The internal circuit connection of the converter ring is a series parallel with two parallel strings.

\section{Detailed Description of Segment}

The segment assembly is shown in Figure 1-8. As previously mentioned, each converter ring contains twenty-eight (28) of these segments. Following is a brief description of the individual components within the segment.

Hot Frame: $\quad$ A cylindrical ring containing 28 flats around its circumference serves as the hot end frame for the segment assemblies. The material is POCO AXF-Q1 graphite, selected because of its high temperature strength and purity. The cylinder is 3.0 inches long, 7.66 inches inside diameter, and .23 inches minimum thickness.

PT Foil: $\quad$ Between the hot current strap and the hot frame is placed a .0005 inch thick foil of Platinum to reduce the thermal resistance between the two. Two foils are used in each segment, one for each row of six legs. 


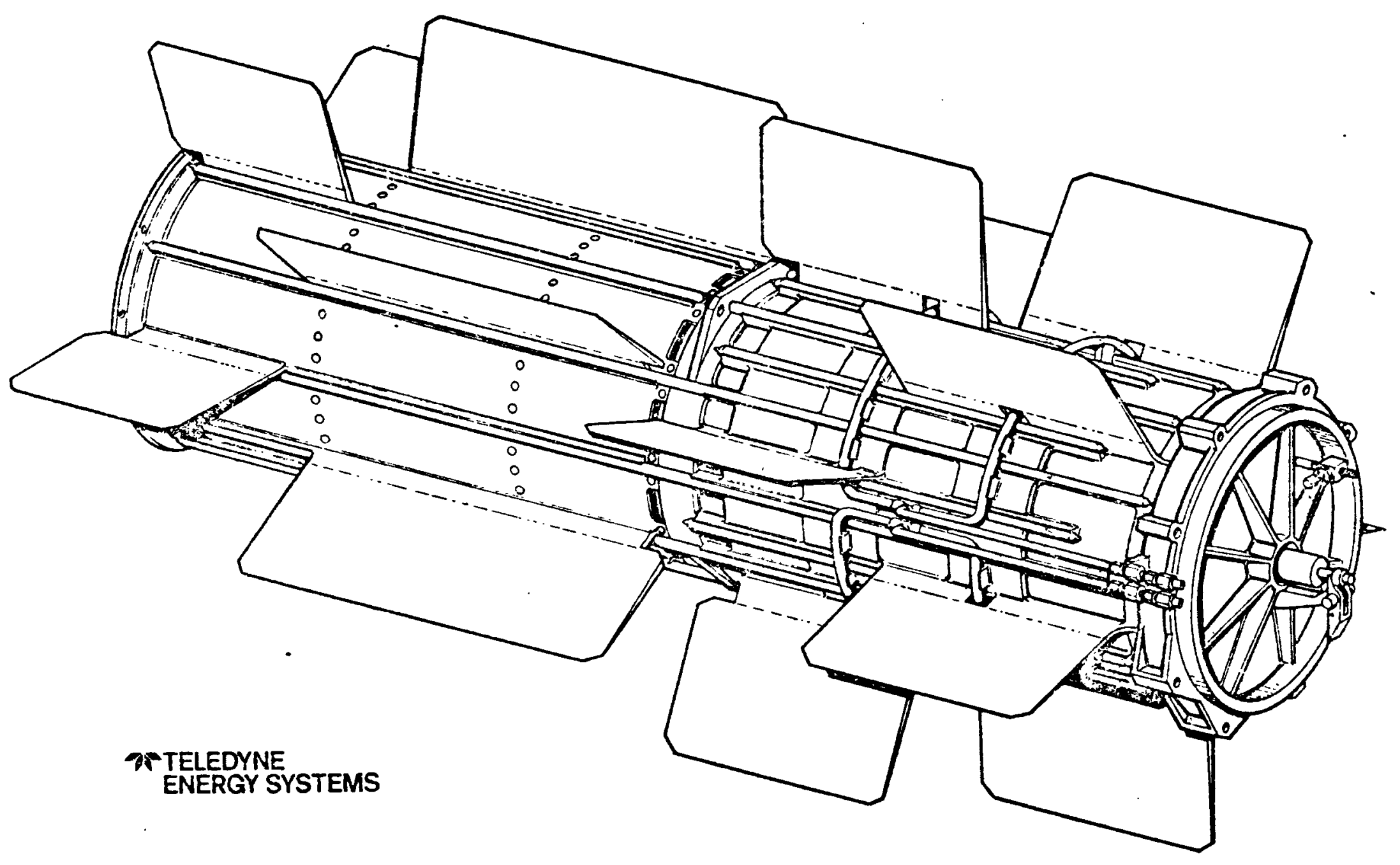




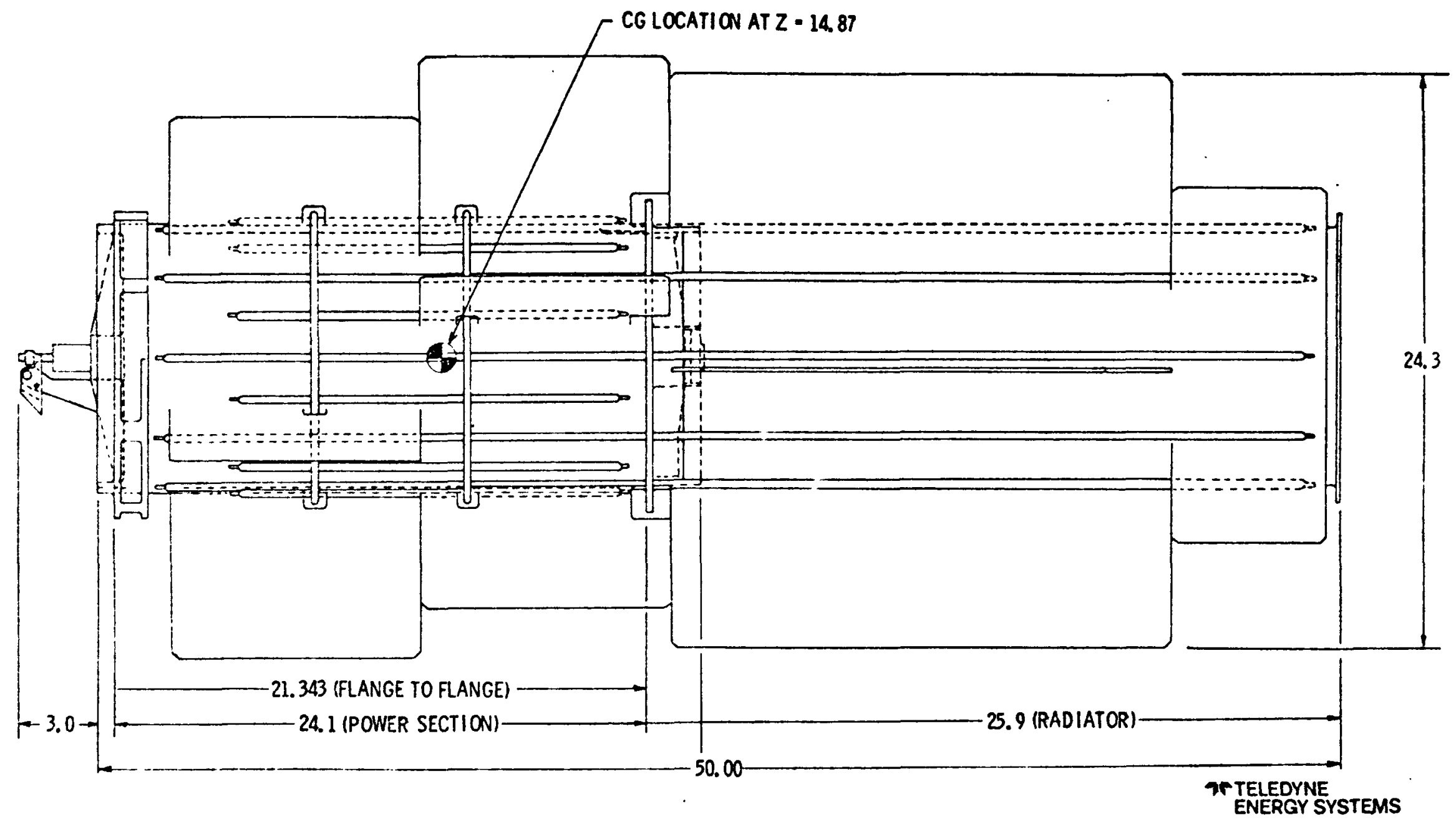

FIGURE I-2: SIG/GALILEO RTG ENVELOPE DIMENSIONS 


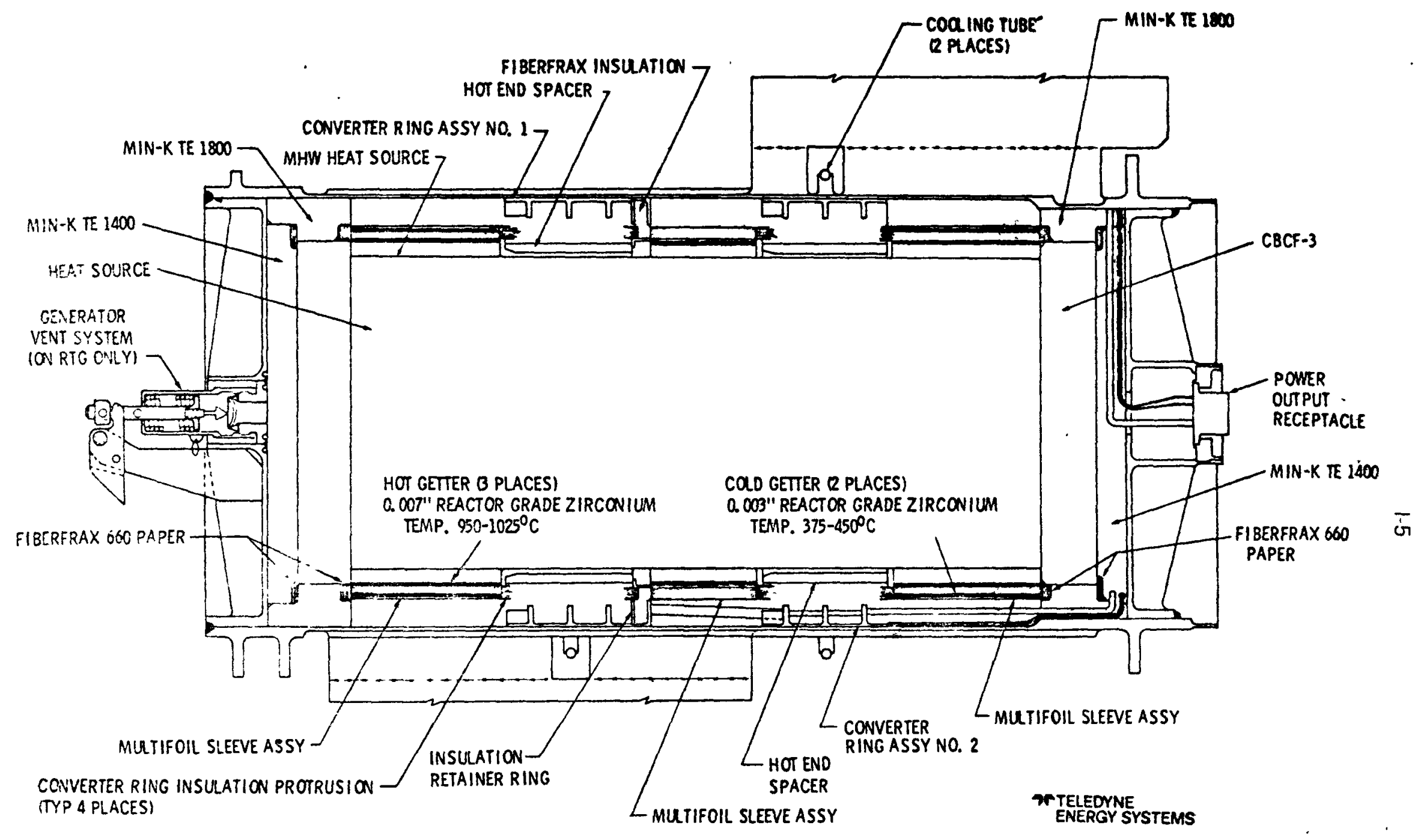

FIGURE 1-3: SIG/GALILEO RTG CROSS SECTION 

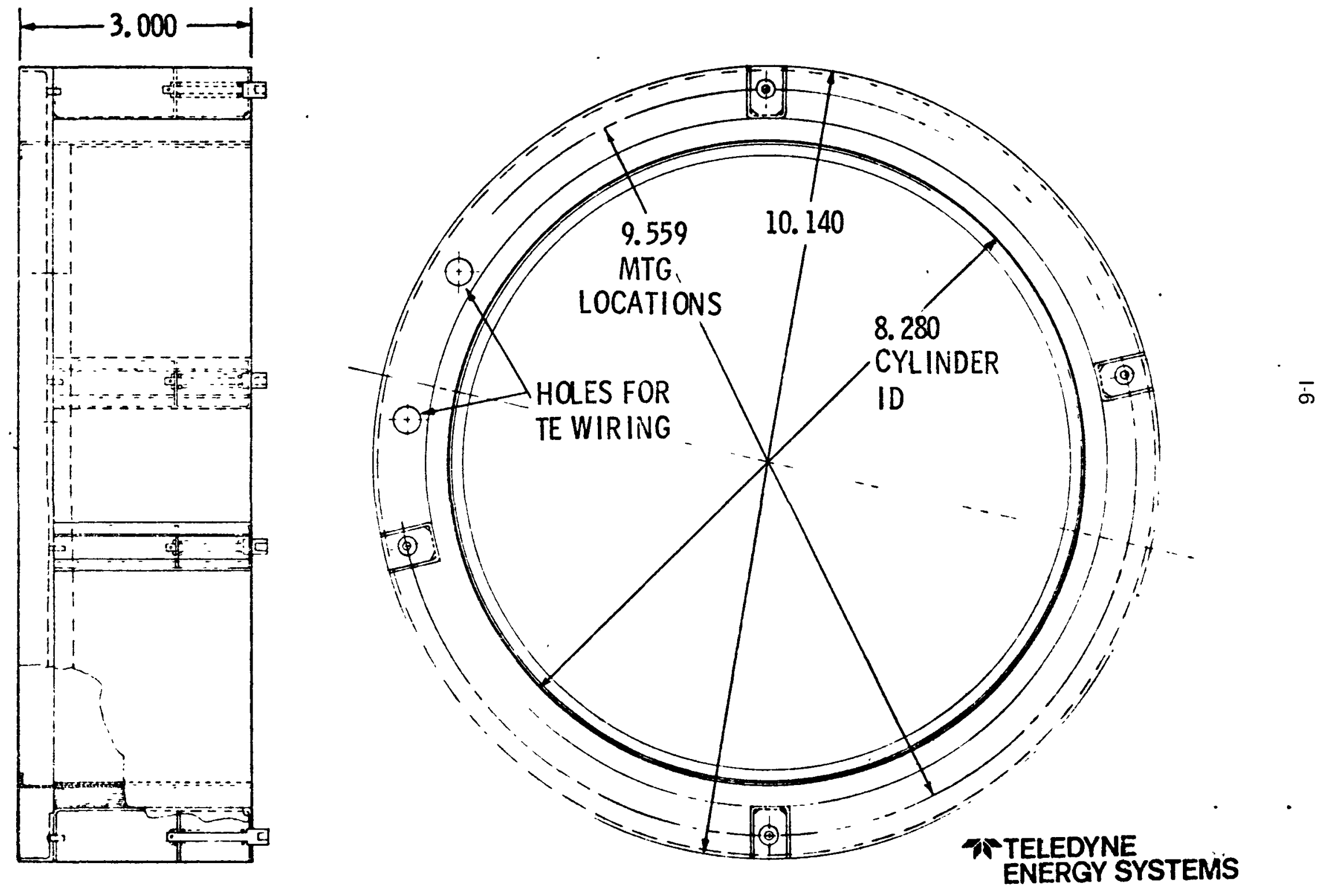

FIGURE I-4: MULTIFOIL INSULATION ASSEMBLY (CENTER SECTION-END SECTIONS SIMILAR) 


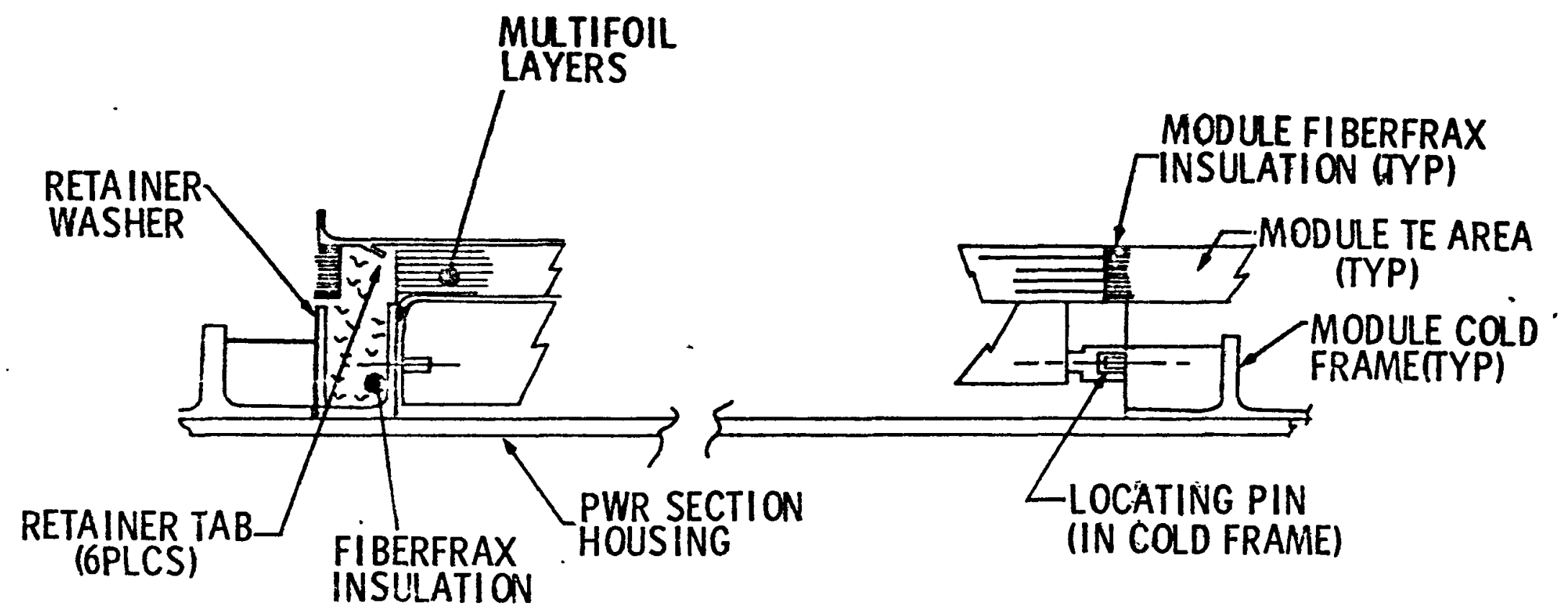




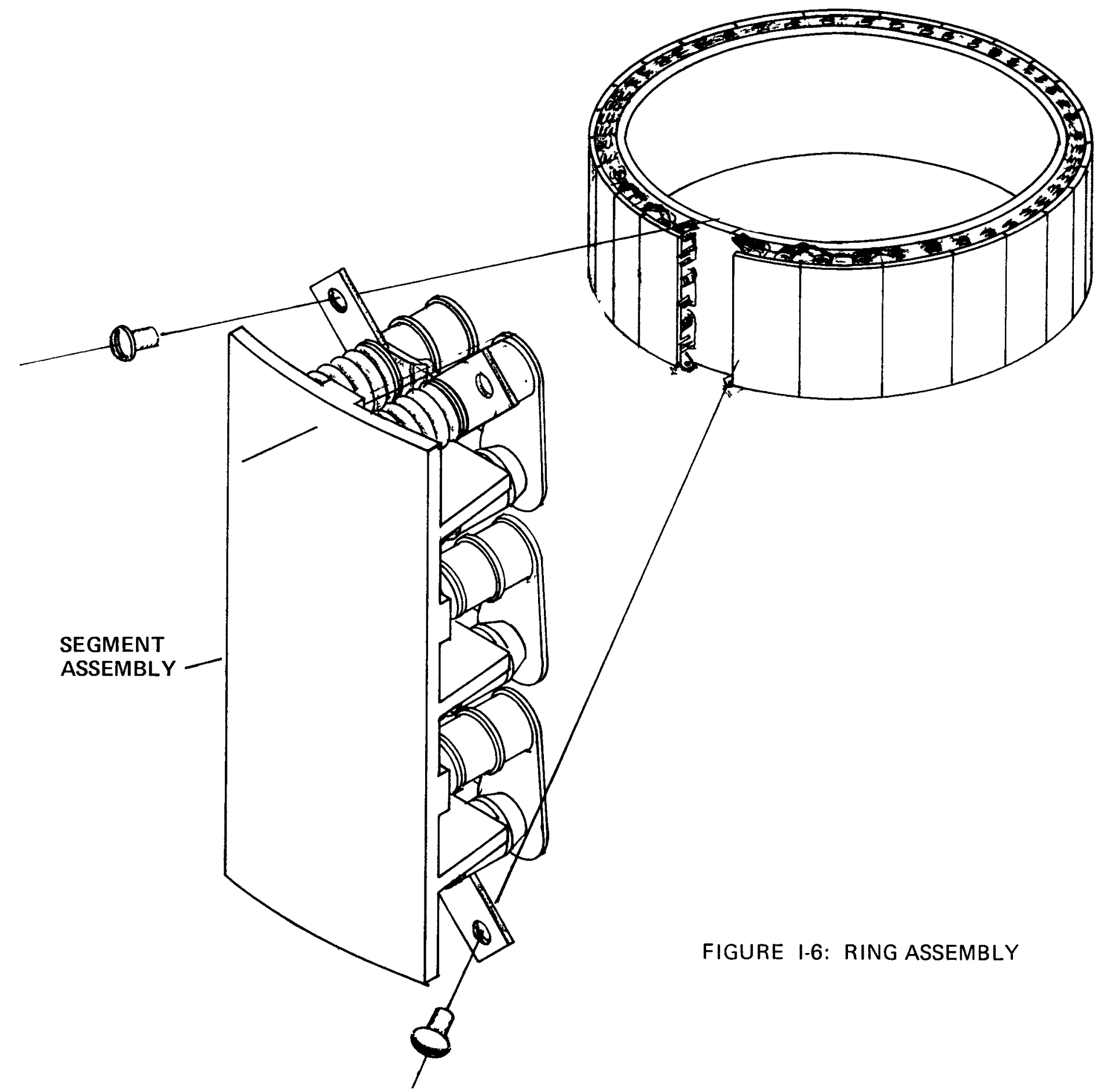




\section{Detailed Description of Segment (Continued)}

Hot Current Strap: The hot current strap is a sculptered " $\mathrm{H}^{\prime}$ configuration made of Molybdenum, .068 inches thick. The hot side of the strap is sprayed with an .015 inch thick coating of $\mathrm{Al}_{2} \mathrm{O}_{3}$ to act as the hot side dielectric. $\mathrm{A}_{2} \mathrm{O}_{3}$ is known for its long term high electrical resistance.

$\mathrm{A}_{2} \mathrm{O}_{3}$ Pin: $\quad$ An alumina pin $\left(\mathrm{A}_{2} \mathrm{O}_{3}\right)$ is used to position the hot strap on the hot frame. The pin is .062 inches in diameter and .206 inches long. It extends from a blind hole in the hot frame, through the Platinum foil and hot current strap, and into a blind hole in the cap of the P-leg.

Gimbal: $\quad$ A conical shaped Molybdenum gimbal is seated into a mating socket of the hot current strap. The purpose of the gimbal is to provide mobility to the $\mathrm{N}$-leg, thereby minimizing high local stresses while maintaining good thermal and electrical contact.

Conducting Disc: A.005 inch thick nickel foil is positioned between the gimbal and the $\mathrm{N}$-leg to minimize thermal and electrical contact resistances while maintaining compatibility with the $\mathrm{GdSe}_{\mathrm{X}} \mathrm{N}$-leg material.

N-Leg Assembly: The N-leg itself is made of conventional GdSe $x$ (.315 inch diameter $x .300$ inches long). The hot end of the leg is sputtered with a thin nickel coating for contact to the nickel foil. The cold end of the leg is sputtered with silver. A layer of LeadSilver-solder (95-5) is then pretinned over the silver sputter. This leg assembly along with the $\mathrm{Ni}$ conducting disk is seated into a recess in the gimbal.

P-Leg Assembly: The P-leg material is Copper Silver Selenide. The outside dimensions of the P-leg are .260 inch diameter $\times .300$ inches long. A .020 thick WRe cap is bonded to the hot end of the leg, while the cold end of the leg has a copper foil bonded to it. The leg is contained within an Astroquartz/Min- $\mathrm{K} \mathrm{H}_{2} \mathrm{O}$ slurry wrap to minimize sublimation.

Cold Frame

Sub-Assembly: The cold frame sub-assembly consists of two smaller sub-assemblies, solder bonded together with a Lead-Tin-Silver (88-10-2) solder preform. (see Figure 1-9)

\section{Current Strap Sub-Assembly (Figure I-10)}

A soldered assembly using the same $\mathrm{Pb}-\mathrm{Sn}-\mathrm{Ag}$ solder as mentioned above. The components are listed and described below:

Cold End Current Strap - These cold current straps are made of .0015 inch thick copper. There are seven layers diffusion bonded at the ends and corners. This maintains the flexibility requirements while offering an excellent conduction path for both electrical and thermal flow. 


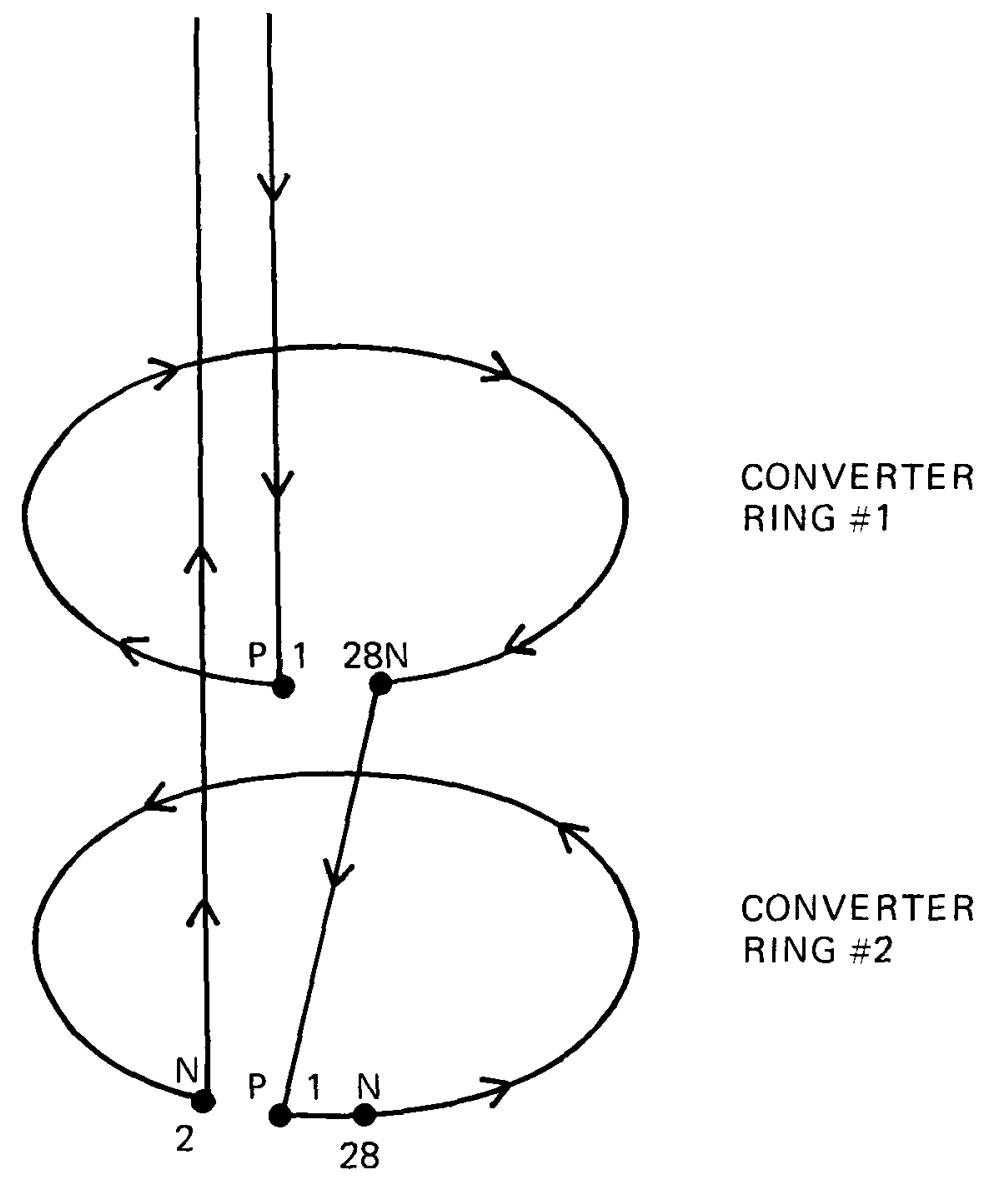

T/C RINGS ALIGNED

\section{NOTES:}

1. ARROWS SHOW DIRECTION OF CURRENT FLOW.

2. DIPOLE FIELDS OF TWO RINGS IN EACH RTE ARE OPPOSED.

FIGURE I-7 POWER CIRCUIT 


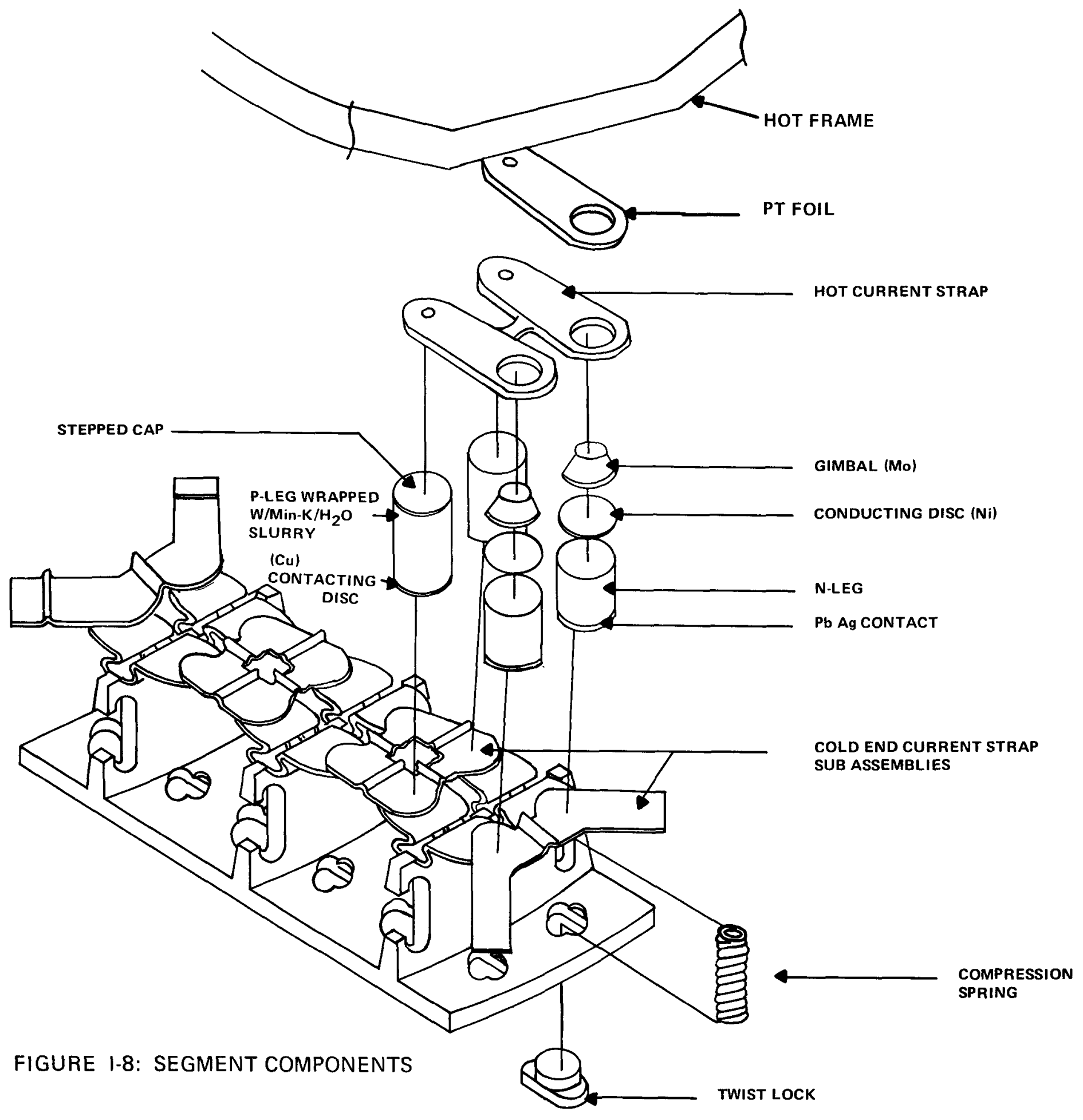




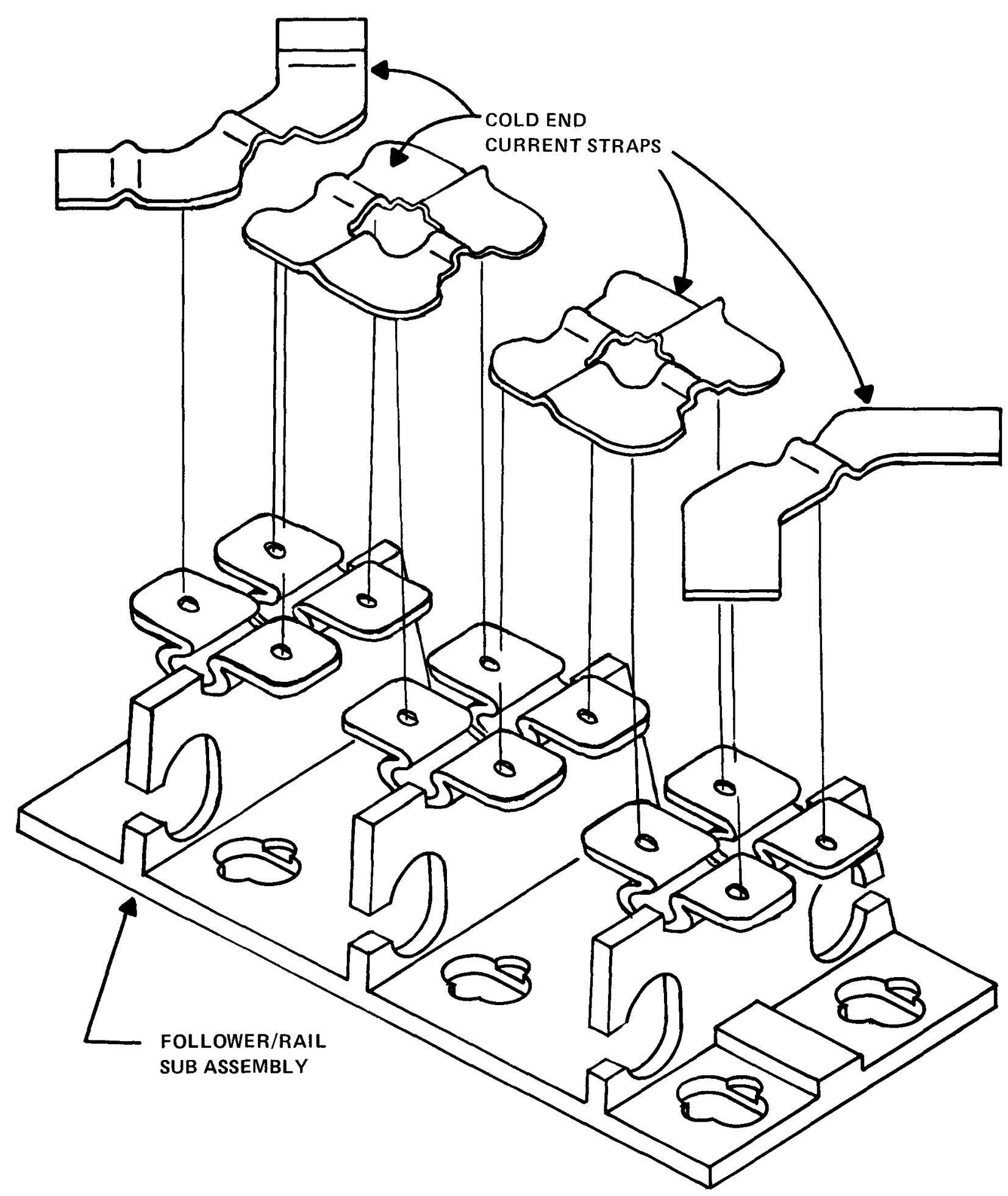

FIGURE I-9: COLD SEGMENT SUB-ASSEMBLY 


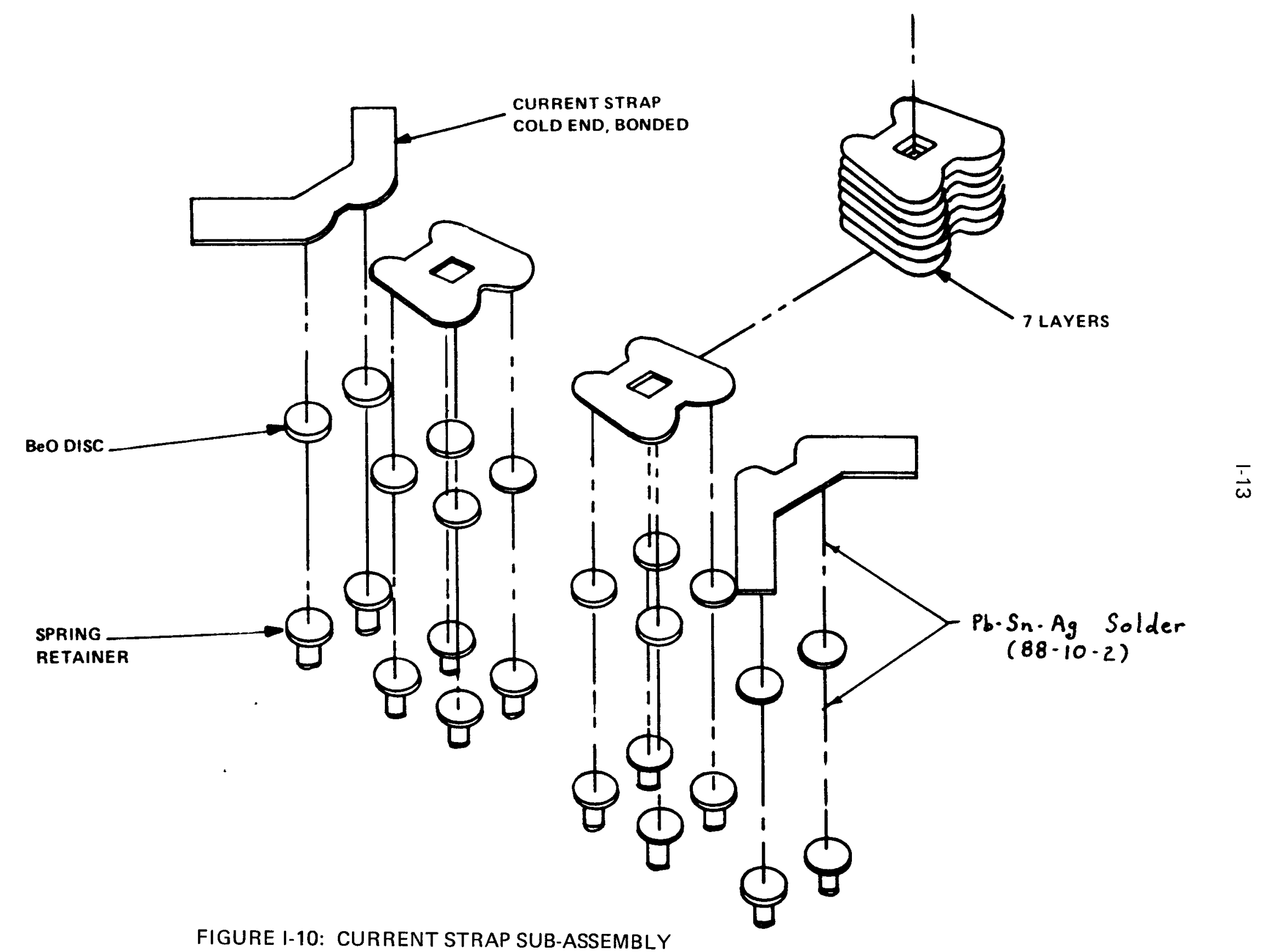


BeO Disk - This disk of Beryllium Oxide serves as the cold end dielectric. The faces of the disk are metallized with MoMn and $\mathrm{Ni}$ plated. This provides for a soldering surface to decrease thermal resistance while maintaining the electrical insulation characteristics of the $\mathrm{BeO}$.

Spring Retainer - A circular copper button which is soldered to the bottom of the $\mathrm{BeO}$ disk. This piece serves to locate and retain the top of the compression spring shown in Figure 1-8.

\section{Follower Rail Sub-Assembly (Figure 1-11)}

Consists of a soldered and riveted assembly with the following components:

Follower - 14 layers of .0015 inch thick copper, diffussion bonded in three places as shown in Figure $1-11$. This configuration is bent as shown to allow for flexibility while maintaining a low resistance heat path to the cold frame segment. The follower is soldered to the cold frame segment with $\mathrm{Pb}-\mathrm{Sn}-\mathrm{Ag}$ (88-10-2) solder.

Cold Frame Segment - This segment serves as the thermal path from the followers to the housing, as well as a locator and mount for the compression spring. It is fabricated of 6061 Aluminum. The top of the three ribs are nickel plated to provide a surface to solder the followers.

Copper Rivet - A copper rivet is installed through each follower and rail as a mechanical backup to the solder bond.

Compression Spring - This spring (17-7 PH Stainless Steel) is inserted between the cold frame housing and the spring retainer, under the legs. It supplies the radial force between the inner hot frame and the outer housing which holds the leg stacks in place. When the converter ring is assembled into the TES housing, these springs are over-compressed to allow for easy insertion. After the ring is in position, the springs are released. They force the cold frame segments radially outward until contact is made with the I.D. of the housing. At this time the pressure on the Nleg stack is 300 psi and the pressure on the P-leg stack is 150 psi.

Twist Lock - The twist lock is secured through holes in the cold frame segment. A button protrudes through the cold frame segment and into the bottom of the compression springs, locating and retaining their position. They are made of 6061 Aluminum and are nickel plated to prevent chip particle formation during installation.

Tin Foil - A .001 inch thick foil of tin is placed between the cold frame segments and the I.D. of the housing to minimize thermal contact resistance. 

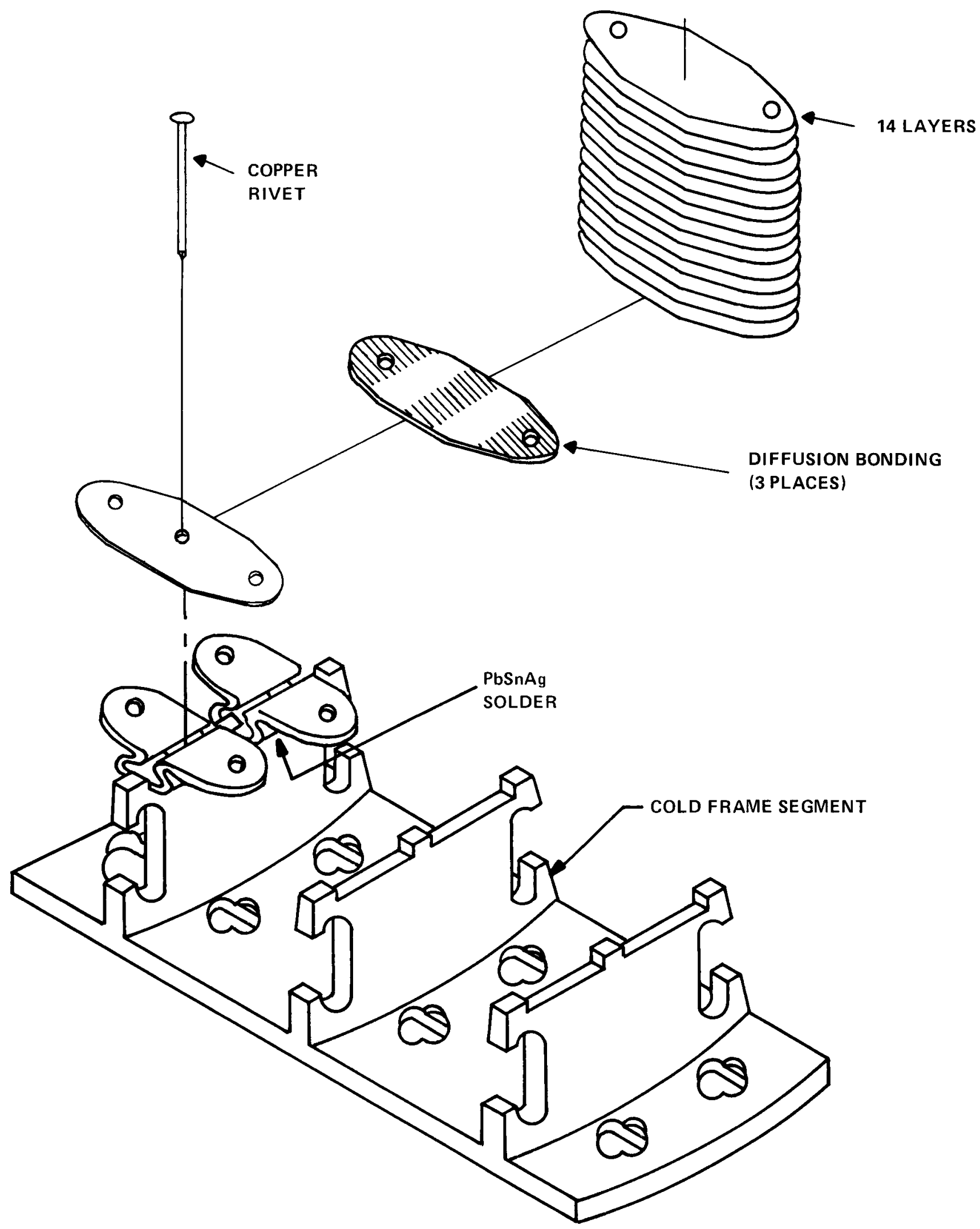

FIGURE 1-11: FOLLOWER RAIL SUB-ASSEMBLY 


\section{ASSEMBLY TOOLING}

The converter ring segments are assembled to the hot frame and secured by means of axial beam tooling. Figure $1-12$ depicts the means by which each segment is held in place on the POCO hot frame.

1. Components of a segment assembly are built up from the hot frame to the cold frame segments.

2. Pile compression bars are slid through the segments.

3. A cylindrical, aluminum, hot frame support is positioned inside the POCO hot frame.

4. Single rod bar clamps are positioned between the ends of the pile compression bars and the hot frame support.

5. By turning the nut on the ends of the bar clamps, each segment can be compressed in turn until the proper O.D. is obtained to allow for a slip fit into the TES housing.

After the entire converter ring is assembled (28 segments) in this manner, and positioned in the housing, the bar clamps are released and removed, along with the pile compression bars and hot frame support.

\section{STATUS OF DESIGN AT TIME OF STOP WORK ORDER}

As of February, 1979, all components of the thermoelectric converter were complete and signed-off. Table 2 lists the drawings that were completed, but not yet reviewed and signed-off.

The interface drawing prepared by TES has been reviewed and signed by $3 \mathrm{M}$ and TES.

Design of in-house equipment for manufacturing cold end hardware was completed and installed at ARO Industries. Fabrication had commenced in January.

Processing equipment was on order. Simulated housing, multi-foil insulation, and converter ring components had been fabricated. Assembly techniques were under investigation with a major practice assembly scheduled for early 1979. 


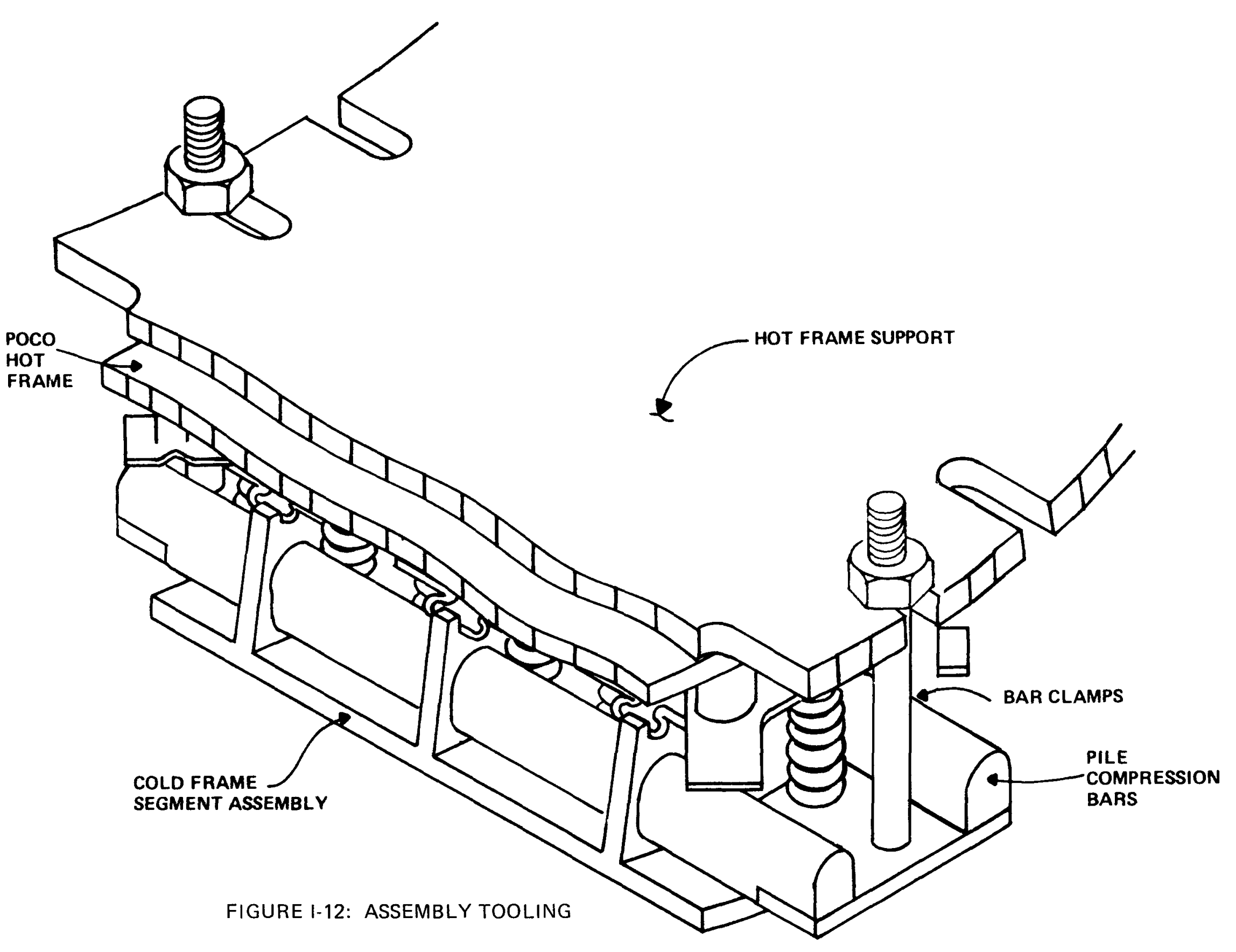


TABLE 1-2

SN-1 DRAWING LIST

\section{Complete and Signed Off}

\author{
Hot Frame \\ Hot End Current Strap \\ and Pt Foil \\ N-Leg Mobility Gimbal \\ P-Leg Mobility \\ $\mathrm{N}$-Leg Assembly \\ P-Leg Assembly \\ Converter Ring Assembly \\ Cold End Hardware \\ Cold Frame Assembly \\ BeO Disk \\ Springs \\ Twist Locks
}

Converter Thermal Insulation

Cold Frame - Housing Tin Interface

Ready for Review
Module and Processing Container Details

Circuit Diagram SG 17-11153

Power Lead and Instrumentation Drawings

Module Assembly

Shipping Container and Shock Instrumentation
SG17-10161

SG17-10195

SG17-10218

SG17-10179-P2

SG17-10171

SG17-10317

SG17-10316

SG17-11152

SG 17-11178-P1

SG17-10015-P1

SG17-11158

SG17-10131

C-1032

C-1055
Completion Date 12/4/78

Completion Date 12/14/78

Completion Date 12/8/78

Completion Date 1/12/79 
TABLE 1-3

SN-1 Completed Drawings

\begin{tabular}{|c|c|c|}
\hline Drawing Number & Title & Materials \\
\hline SG17-11152 & Converter Ring Assembly & $x$ \\
\hline SG17-10161 & Spacer, Hot End & \\
\hline SG17-10218 & Foil, Hot Shoe & \\
\hline SG17-10171 & Pin & \\
\hline SG17-10195 & Strap, Current Hot End & \\
\hline SG17-10316 & P-Leg Assembly Wrapped & $x$ \\
\hline SG17-10314 & Capped P-Leg & \\
\hline SG17-10089-P1 & Contacting Disc & \\
\hline C-1033 & Quartz Yarn & \\
\hline SG17-10317 & N-Leg Assembly & $x$ \\
\hline SG17-10312 & N-Leg & \\
\hline C-1060 & Solder & \\
\hline SG17-11178-P1 & Cold Frame Assembly P1 & $\mathrm{x}$ \\
\hline SG17-11172 & Follower-Rail, Sub-Assembly & $x$ \\
\hline SG17-11155 & Cold Frame Segment & \\
\hline SG17-11173 & Rivet & \\
\hline SG17-10156 & Follower, Multi-Layer Bonded & \\
\hline SG17-11177-P1 & Foil, Cold Strap, Sub-Assembly P1 & $x$ \\
\hline SG17-11177-P2 & Foil, Cold Strap, Sub-Assembly P2 & $x$ \\
\hline SG17-11177-P4 & Foil, Cold Strap, Sub-Assembly P4 & $x$ \\
\hline SG17-11175-P1, P2 & Strap Current Foil End & \\
\hline SG17-11176-P1 & Strap Current Foil End & \\
\hline SG17-10015-P1, P2 & Disc, Insulating & \\
\hline SG17-10157-P1, P2 & Retainer, Spring & \\
\hline SG17-11158 & Spring Element & \\
\hline SG17-10131 & Twist Lock & \\
\hline C-1032 & Insulation, Sheet & \\
\hline SG17-10179 & Gimbal & \\
\hline
\end{tabular}




\section{B. CONVERTER DESIGN ACTIVITY}

By September, 1978, a majority of the piece part designs for SN-1 had been completed.

Extensive efforts were being directed to finalize the design of the flexible follower. It was felt that the new flexible follower design would provide the solution to the follower hang-ups encountered with the older sliding-follower version. The new design would incorporate 14 layers of .0015 inch thick copper into one flexible strap, bonded at the ends. The process to be used for bonding was not yet resolved. Although efforts to ultrasonically bond the copper looked promising, the developement was slow. Diffusion bonding was an alternative which appeared to not only give a good metallurgical bond, but would be relatively easy for initial manufacturing start-up. A glove box and diffusion bonding fixture were installed in September.

Methods of bonding the various cold end hardware components to each other were also being considered. After testing alternate solders, fluxes, and other bonding techniques, it was felt that the job could best be accomplished with a (88-10-2) Pb-Sn-Ag solder and special high temperature flux developed by Kester. The soldering was performed in special holding fixtures under a helium atmosphere. This soldering operation would follow the following sequence:

1. Solder six followers to cold frame segment

2. Solder BeO disk, cold end current strap, and spring retainer together.

3. Solder the sub-assemblies obtained in items No. 1 and No. 2 above, together.

In addition to the solder joint, it was requested that an additional back-up means of securing the followers to the cold rail segments be incorporated. This was accomplished by means of a copper nail which is pressed through the copper and rail, then formed over into a head in the far side. This then, acts as a rivet, providing the positive mechanical securement requested.

Efforts were also being made at this time to investigate alternative methods of producing a .001 inch layer of tin between the cold frame segment and housing. Tin foil (reference design) would be difficult to assemble without producing tears or wrinkles. While TES was requested to look at the feasibility of applying a $1 \mathrm{mil}$ tin plating to the inside surface of the housing, 3M looked at methods of applying a 1 mil tin plating to the outside surface of the cold frame segments. Tinning the cold frame segments, however, had to be done after all soldering was completed because of the low melting temperature of tin. This procedure proved difficult due to the extensive masking required. Efforts to provide an efficient means of masking by several plating firms were dropped. The decision was made to continue to use the $1 \mathrm{mil}$ tin foil.

On October 16, 1978, a preliminary design review was held. Changes to drawings, resulting from the review, were then performed. By late November, these drawings were complete and signed-off. A data package containing these prints was sent to DoE. Table $1-3$ provides a list of these drawings.

During October and November of 1978, the plans for a complete, full scale practice assembly were developed. Prototype converter components were designed and a simulated plexiglass housing was 
ordered. The practice assembly, scheduled for early 1979, would be a valuable aid in investigating the following areas:
a) Development of manufacturing procedures
b) Particle generation
c) Insulation stuffing techniques
d) Instrumentation and power lead routing
e) Installation tooling
f) Circuit connection (riveting) techniques
g) Tin foil installation
h) Leg misalignment

By February, all components and equipment, required to proceed with the practice assembly, were on hand. However, the practice assembly was not initiated before the stop work order was issued.

On November 27-30, a design review was held at DoE, Washington, DC. Shortly following this meeting, most of the remaining designs concerning the converter assemblies and the processing and handling equipment were completed.

Short run production was set up to manufacture cold end hardware components (diffusion bonding, soldering) at ARO Industries. A number of tooling modifications were introduced to the bonding process at this time. These changes were primarily directed at insuring the reproducibility of quality bonds.

During the early part of 1979 , short run production at ARO Industries had begun the initial phases of cold end hardware bonding. As the Galileo Contract close-out became apparent, however, activity at ARO Ind. was reduced. During March, 1979, the equipment at ARO was withdrawn back to Building 260 and reinstalled. The amount of hardware bonding has since been limited to technology efforts only. 
3M/TES Interface Activity

Throughout the course of the Galileo Contract, frequent meetings between TES and 3M were held. These meetings served to maintain the necessary coordination between $3 \mathrm{M}$ and TES on the interfacing issues. In addition to the interface meetings, frequent telephone consultation took place on topics of mutual concern.

The initial meetings in June and July of 1978 were aimed at confirming dimensional parameters and resolving any interface problems between the converter rings and the multi-foil insulation can to be placed between them.

The following list relates the problem areas that surfaced and were resolved during the program:

1. Hot Frame:

- Dimension information on hot frame was supplied to TES

2. Cold Frame:

- Dimensional information supplied

- TES requires 16 RMS finish on cold frame segment

- TES supplied coordinate axis system to be used for the generator. $3 \mathrm{M}$ will position the converter ring assemblies with the No. 1 segment centered on the $x+$ axis (see Figure 1-13)

- Locating pins between the cold frame segments and the housing will be left out initially. They will be added if required for additional stabilization during vibration.

- Design for two locating pins between the converter ring and multi-foil gussets was completed. The two pins (.032" dia.) would be located in raised bosses of the cold frame segments, $180^{\circ}$ apart on a ring. They would lock into special spring plungers located in the TES multi-foil gussets.

3. Foil interface:

- TES requires .001 inch thick foil of $100 \% \mathrm{Sn}$ between the cold frame segments and the housing. Tin plating was investigated but did not prove to be a viable alternative.

4. Instrumentation and Power Leads:

- Gauge and length of wire supplied to TES

- Orientation of instrumentation wires within the generator were determined.

- Insulation over wires determined

- T/C locations determined

- Power lead runs were defined as running along the $x+$ axis. TES initially recommends a spiral winding to prevent a dipole formation. This was later determined to be unnecessary. The current path of converter ring No. 1, however, must run opposed to the current path of ring No. 2 for the reason mentioned above. 

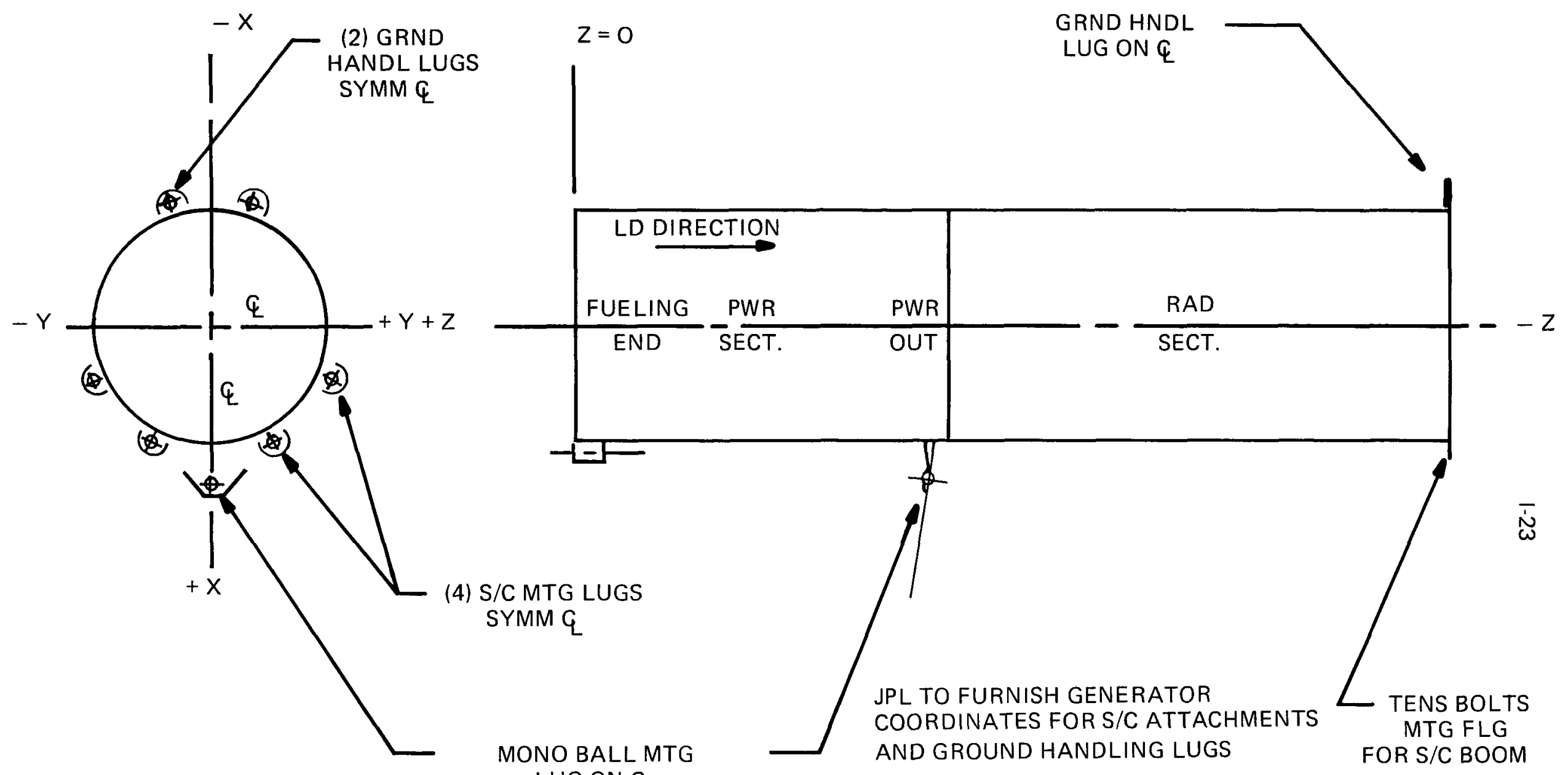

FIGURE I-13: GENERATOR GEOMETRIC DATA SHEET 
5. Generator Housing:

- A step in the I.D. of the housing would prevent the use of the presently designed installation tooling. TES agreed to move the step closer to the power end to allow room for $3 \mathrm{M}$ tooling.

6. Auxiliary Cooling Tubes:

- $3 \mathrm{M}$ recommended the location of the auxiliary cooling tube connections.

7. Insulation:

- The type of insulation between the multi-foil ring and the converter rings, and the assembly procedure related to the insulation were of extreme concern. Table 1-4 was presented by TES to relate the various combinations of insulation and tooling gaps to the power output. It is evident from the table that the tooling gaps that must be filled with insulation should be kept to a minimum. $3 \mathrm{M}$ redesigned the assembly tooling to provide for $1 / 8$ inch gap in three places, and a $3 / 8^{\prime \prime}$ maximum gap in one place. This was accomplished by going from a double rod clamp (No. 4-40) to a single rod clamp (No. 10-32).

8. Shipping and Processing Container:

- Dimensional information by TES verified on housing fin O.D.

- $3 \mathrm{M}$ agreed to mount the housing to the processing container from the fuel end rather than the power end. 
TABLE I-4

Tooling Gap Effect on Performance

\begin{tabular}{|c|c|c|c|c|c|c|}
\hline Insulation & \multicolumn{4}{|c|}{ Fiberfax (4 Places) } & $\begin{array}{l}\text { M.F. on Outer } \\
\text { Region. CBCF-6/ } \\
\text { Min-K Middle } \\
\text { 1/8" Fiberfax }\end{array}$ & $\begin{array}{l}\text { CBCF-6/Min-K } \\
\text { Throughout } \\
\text { (ideal case) }\end{array}$ \\
\hline Gap & 0 & $1 / 16^{\prime \prime}$ & $1 / 8^{\prime \prime}$ & $1 / 4^{\prime \prime}$ & & \\
\hline Power (Watt) & 230.5 & 229.5 & 228.4 & 226.3 & 217.7 & 216 \\
\hline$\Delta \mathrm{Q}$ & 0 & 10.5 & 21 & 42 & & \\
\hline
\end{tabular}

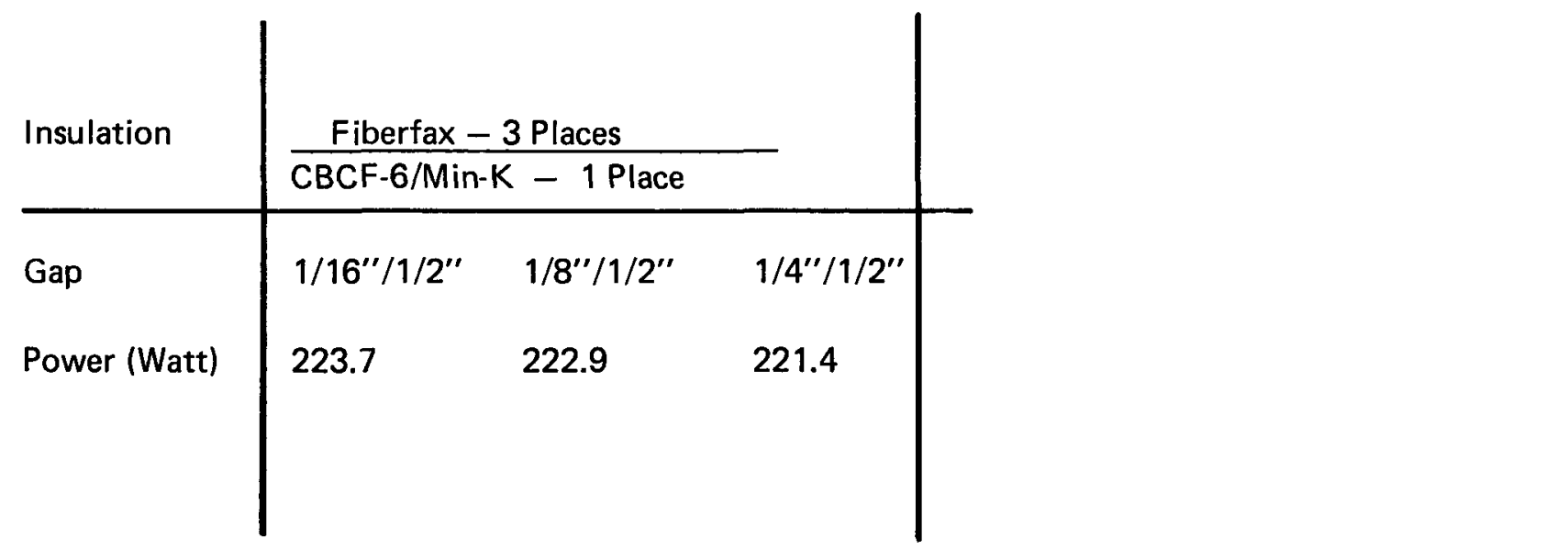




\section{DESIGN DOCUMENTATION}

This section lists the various design related documentation that was completed during the contract.

\section{Design Drawing}

Table 1-5 lists the design drawings which were completed and signed-off for the $\mathrm{SN}-1$ converter, along with the additional designs which were completed but did not reach the final sign-off stage before the stop work order.

\section{Specifications and Procedures}

Those engineering specifications and procedures that were completed and issued are shown in Tables I-6 and I-7 as follows:

Table I-6 - Engineering Specifications - Raw Materials

Table 1.7 - Manufacturing Standards (those without dates were not completed)

\section{Design Analysis}

This section lists some of the significant analysis reports that were used in support of the converter design. These attachments will be found in the back of this section.

\begin{tabular}{|c|c|}
\hline Attachment 1 & Assembly Tooling Options \\
\hline Attachment & $\begin{array}{l}\text { Spring Characteristics of Follower with Increased } \\
\text { Thickness }\end{array}$ \\
\hline Attachment 3 & Assembly of Cold End Hardware \\
\hline Attachment & Compliant Follower Spring Force \\
\hline Attachment & Cold End Hardware Spring Force \\
\hline Attachment 6 & Determination of Stress on $N$ and $P$ Legs \\
\hline Attachment 7 & Load Relaxation in Springs \\
\hline Attachment & $\begin{array}{l}\text { Weight and Exposed Surface Area of Cold End } \\
\text { Copper Hardware }\end{array}$ \\
\hline Attachment & SN-1 Weight Analysis \\
\hline Attachment 10 & Initial Phases of Axial Stress on N and P Legs \\
\hline Attachment 11 & Copper Stiffening During Diffusion Bonding \\
\hline Attachment 12 & Reproducibility of Cold End Hardware $\Delta T$ \\
\hline
\end{tabular}




\section{TABLE 1.5}

SN-1 Completed and Approved

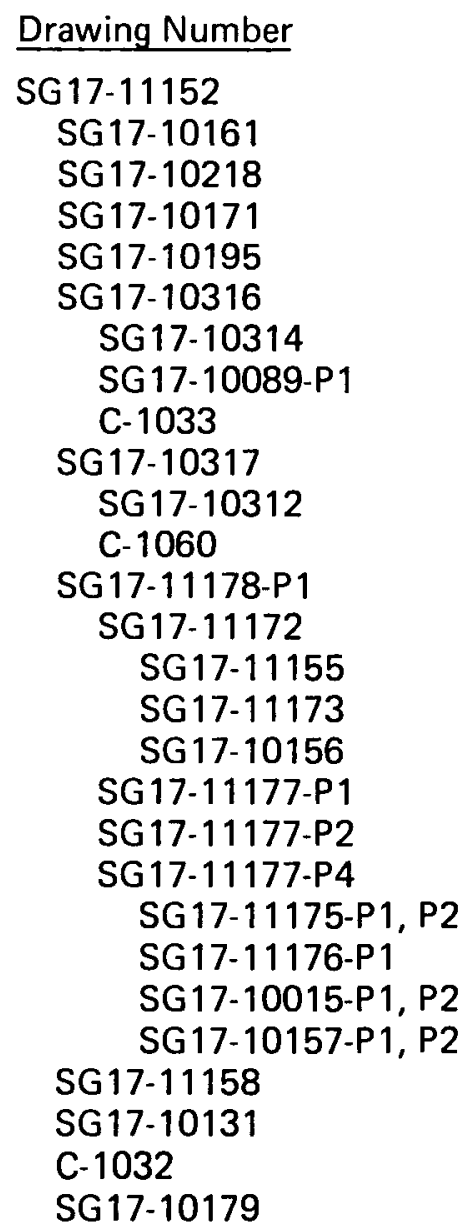

Title

Converter Ring Assembly

Spacer, Hot End

Foil, Hot Shoe

Pin

Strap, Current Hot End

P-Leg Assembly Wrapped

Capped P-Leg

Contacting Disc

Quartz Yarn

N-Leg Assembly

$\mathrm{N}$-Leg

Solder

Cold Frame Assembly P1

Follower-Rail, Sub-Assembly

Cold Frame Segment

Rivet

Follower, Multi-Layer Bonded

Foil, Cold Strap, Sub-Assembly P1

Foil, Cold Strap, Sub-Assembly P2

Foil, Cold Strap, Sub-Assembly P4

Strap Current Foil End

Strap Current Foil End

Disc, Insulating

Retainer, Spring

Spring Element

Twist Lock

Insulation, Sheet

Gimbal

\section{Complete But Not Signed Off}

Module Assembly, SN-1

Module and Shipping Container Assembly

Heater Assembly

Flange, Mounting

Cover, Shipping Container

Protector, Mounting Surface

Heater Block Assembly

Plate, Clamping

Heater Support

Insulator, Support

Pad, Insulation

Bracket, Mounting Heater Block

Heater Block

Stand-Off, Module

Eyebolt, Lifting
Bill of

Material

$x$

$x$

$x$

$x$
$x$

$x$

$x$ 
TABLE I-6

ES's

1000 Series - Raw Materials

\begin{tabular}{|c|c|}
\hline 1001 & POCO Graphite (AXF-Q1) - 12/21/78 \\
\hline 1002 & Platinum Foil - 99.95\% Pure - 12/21/78 \\
\hline 1003 & Aluminum Oxide $-12 / 21 / 78$ \\
\hline 1004 & Molybdenum \\
\hline 1005 & Stainless Steel (17-7 PH) - 12/21/78 \\
\hline 1006 & Aluminum (2024 T351) - 12/21/78 \\
\hline 1007 & Aluminum (6061 T6) \\
\hline 1008 & Beryllium Oxide $-12 / 21 / 78$ \\
\hline 1009 & Tungsten - 25 Rhenium - Cold Worked - 12/21/78 \\
\hline 1010 & Nickel - UNS No. 2201 - Annealed - 12/21/78 \\
\hline 1011 & $\mathrm{~Pb}-\mathrm{Sn}$-Ag Solder - 12/21/78 \\
\hline 1012 & $\mathrm{~Pb}-\mathrm{Ag}$ Solder - 12/21/78 \\
\hline 1013 & ETP Copper - Alloy No. 110 - Hard - 12/21/78 \\
\hline 1015 & Astroquartz Fiber - 12/21/78 \\
\hline 1016 & Min-K 1800 Insulation - 12/21/78 \\
\hline 1017 & Thermocouple Wire (Pt and $\mathrm{Pt} / 10 \% \mathrm{Rh})-12 / 21 / 78$ \\
\hline 1018 & Fiberglass Sleeving $-12 / 21 / 78$ \\
\hline 1019 & Gadolinium - 12/21/78 \\
\hline 1020 & Selenium - 12/21/78 \\
\hline 1021 & Copper - 12/21/78 \\
\hline 1022 & Silver - 12/21/78 \\
\hline 1014 & OFE Copper - 12/21/78 \\
\hline 1023 & Tantalom \\
\hline 1024 & Fiberfrax Hi-Fi 660 Paper - 12/21/78 \\
\hline 1025 & Fiberfrax H-Blanket - 12/21/78 \\
\hline 1026 & Nickel Foil - 5/9/79 \\
\hline 1027 & Iron Foil - 5/9/79 \\
\hline
\end{tabular}


TABLE I-7 - Manufacturing Standard Instructions

\section{Assembly Method}

MSI 3001 Thermoelectric Assembly 9/27/77

3002 Cold Strap Assembly 9/27/77

3003 Feedthrough Assembly

3005 Brazing Procedure - 9/27/77

3006 Determining Length of Follower Spring $11028-9 / 27 / 77$

3007 Riveting End Current Straps $4 / 18 / 78$

3008 Diffusion Bonding Followers $10 / 20 / 78$

3009 Folding of Current Straps and Bonding Procedures

3010 Procedure for Soldering Complete Current Straps and Cold End Straps to Follower and Rail Assembly

3011 Soldering of Spring Retainers to Current Straps

3012 Procedure for Soldering Follower to Rail

3013 Procedure for Solder Spring Retainers, BeO Discs to Cold End Straps

3020 Folding of Follower Foils

3021 Folding of Current Strap Foils (4-Plex)

\section{Processing}

MSI 2001 Thermoelectric Module Outgassing and Heat-Up Procedure $-8 / 17 / 77$

2003 Outgassing Procedure for Thermal Insulation used in Thermoelectric Modules - 9/27/77

2004 Outgassing Procedure for POCO Graphite Hot Frame and Heater Block Pieces - 9/27/77

2005 Processing Fiberglass Sleeving Insulation

2006 Thermoelectric Module Outgassing Heat-Up and Backfill - 4/13/78

2012 Outgassing Procedure for POCO Graphite Hot Frame and Heater Block Reworked Pieces - 4/5/78

2008 P-Leg Processing Procedure 10/17/75

2009 N-Leg Processing Procedure $4 / 28 / 76$

2013 Outgassing Procedure for Thermal Insulation

2014 Thermoelectric Converter Outgassing and Heat-Up Procedure

2015 Thermoelectric Module Outgassing and Heat-Up Procedure - 12/12/78

\section{Cleaning Method}

MSI 1001 Thermoelectric Module Cleaning Procedure 9/27/77

1002 Cleaning Procedure for $\mathrm{T} / \mathrm{C}$ Wires and Heater Leads - 9/27/77

1003 Thermoelectric Module Cold Frame Cleaning Procedure - 9/27/77

1004 Cleaning Method for Metal Parts 


\section{TABLE 1-7 - Manufacturing Standard Instructions (Continued)}

Assembly Method

Processing

Cleaning Method

3022 Folding of Current Strap

Foils (P-End)

3023 Folding of Current Strap Foils (N-End)

3024 Rivet Forming

3025 Procedure for Diffusion Bonding of Follower Foils

3026 Diffusion Bonding of Current Strap Foils (4-Plex)

3027 Diffusion Bonding of Current Strap Foils (P-End)

3028 Diffusion Bonding of Current Strap Foils (N-End)

3030 Instrumentation of " $P$ " Legs $4 / 30 / 79$ 
D. ATTACHMENTS TO SECTION I 


\section{ATTACHMENT 1}

Assembly Tooling Options

A number of alternatives for assembly tooling have been investigated. The method which appears to be the optimum design for reducing the tooling gap is the single rod clamp. This method is very similar to the original design. However, instead of two (2) No. 10-32 rods for clamping, only one (1) No. 10-32 rod is used. This allows positioning of the clamps directly adjacent to each other. There is now no need to allow additional clearance for the nuts. The tooling gap which can now be expected has been reduced from .5 inches to .28 inches. The remaining tooling options produce a tooling gap from .38 inches to .45 inches.

In addition to the decrease in tooling gap, the following other advantages have been noted:

1. Reduced labor in assembly:

The single rod clamps reduce the number of nuts that have to be assembled and disassembled from 112 to 56 .

2. Ease in handling:

Other tooling options that were investigated required the use of No. 4-40 size nuts and rods. This is a very difficult size to work with during assembly with gloves. The No. 10-32 size of the single rod clamp eliminates this problem.

3. Reduced stress on legs:

When assembling and disassembling the double rod clamp tooling, the four rods and nuts for each segment must be alternately turned. This causes stresses on the legs in four directions. The use of single rod clamps reduce the number of directional stresses to two.

Tooling, which makes use of the single rod clamp, was ordered for SN-1. An additional set of tooling was ordered for practice assembly.

Designs have also been drawn and parts are on order to use the single rod clamp on M21 through M29. These will give sufficient data to determine if there are any problems associated with the use of this tooling method. 


\title{
ATTACHMENT 2
}

\author{
Spring Characteristics of Follower \\ with Increased Thickness
}

\begin{abstract}
A test was conducted on the six-couple station with the compliant hardware and it was detected that the heat transfer through the follower was not as good as anticipated. One possible solution to this problem is to increase the layers of foil in the follower from fourteen (14) to sixteen (16) or eighteen (18), but with this increased thickness, the follower will get stiffer. If this stiffness would get too large, the follower would take up too much of the spring force and the stress on the legs would fall below the required value. Therefore, this attachment describes the results from tests to determine the spring characteristics of sixteen (16) and eighteen (18) layer followers.
\end{abstract}

$\underline{\text { Results }}$

The results are in the form of two (2) graphs (Figures 2-1 and 2-2) which are a sixteen (16) and eighteen (18) layer follower displaced and returned to original position.

Note: Tension is positive, compression negative, and the directional sign follows Figure 2-3. 


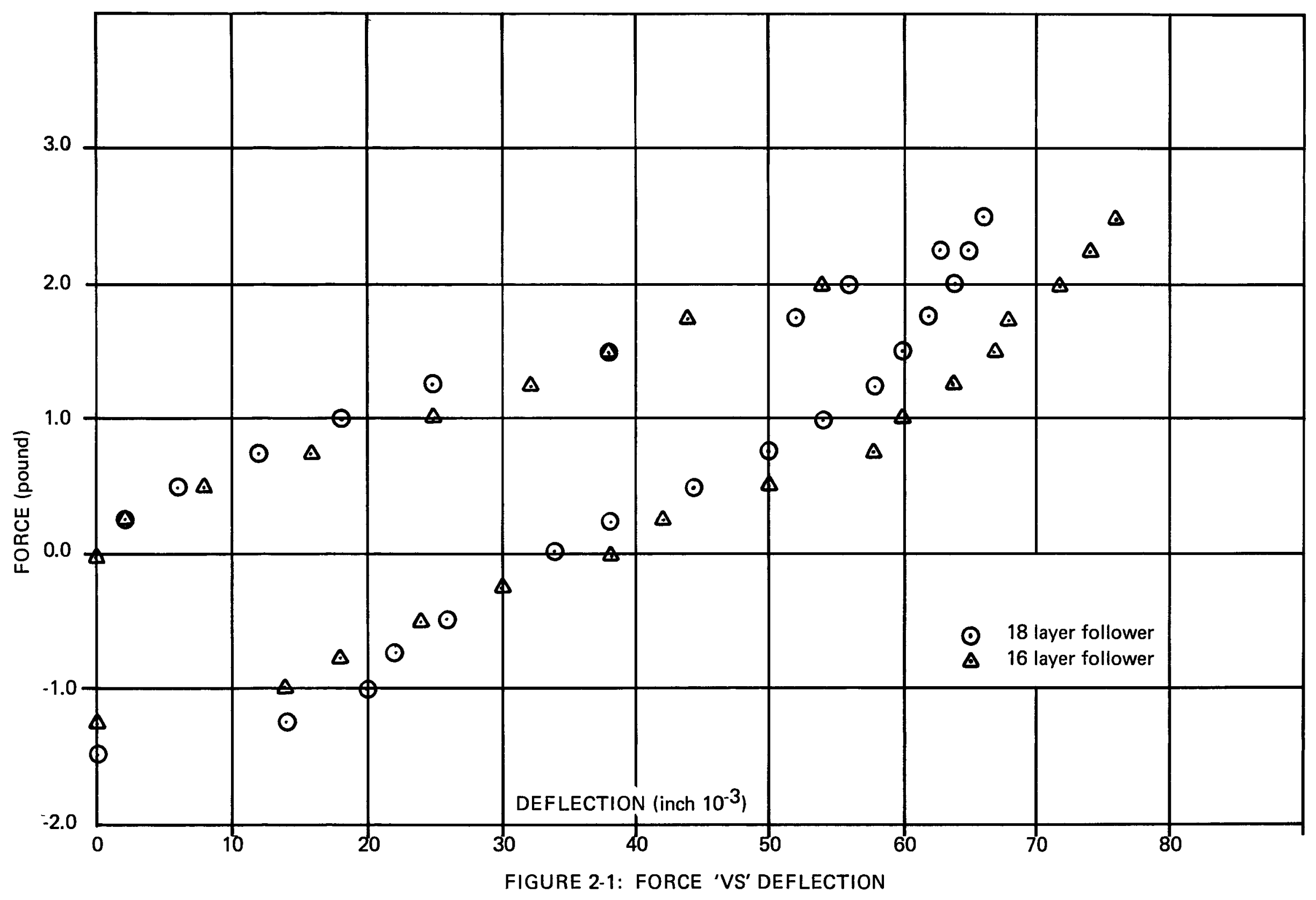




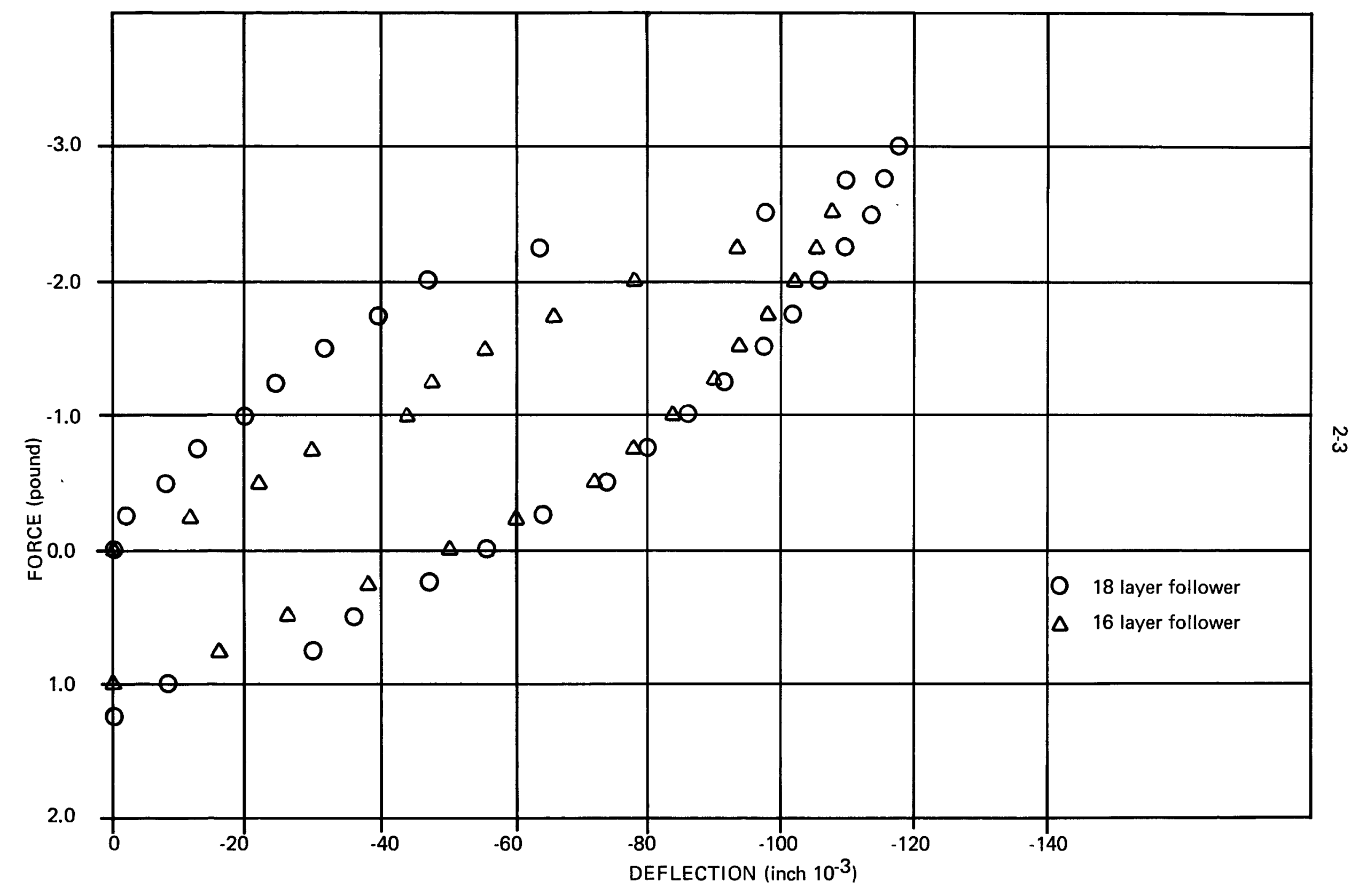

FIGURE 2-2: FORCE 'VS' DEFLECTION 


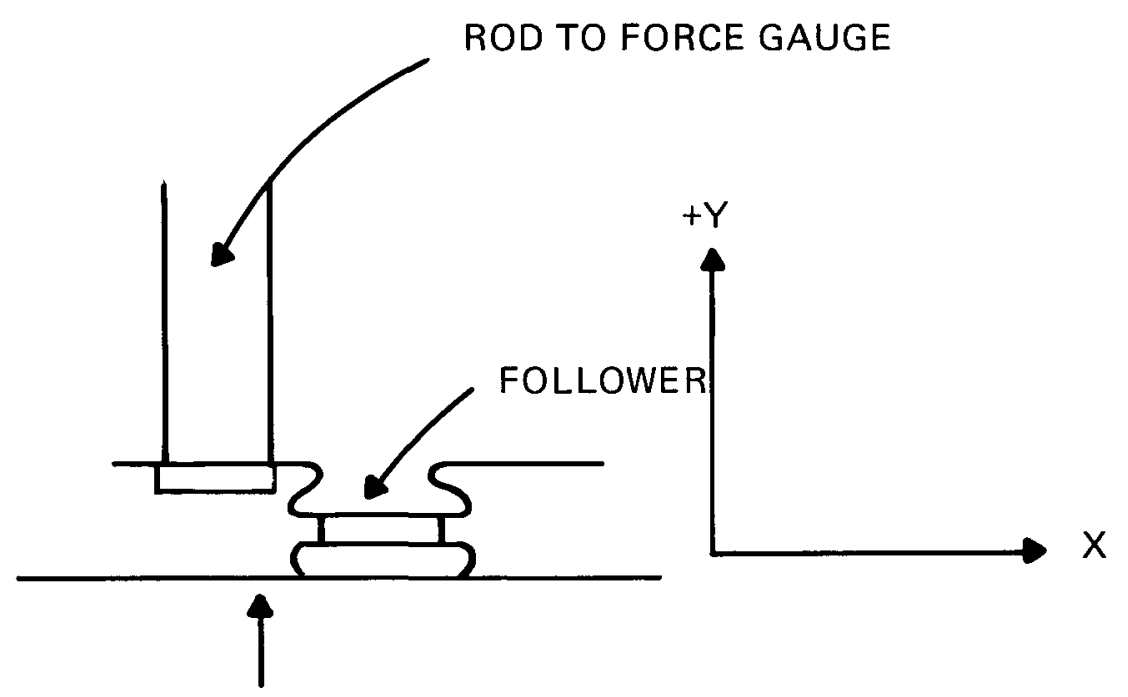

BASE OF SPRING TESTER

FIGURE 2-3 


\section{ATTACHMENT 3}

Assembly of Cold End Hardware

The following is a procedure for the assembly of cold end hardware. Due to the complexity of the procedure, it was felt that an outline would tend to clarify any misunderstandings or uncertainties.

The procedure can be treated as a reference towards the final assembly specification. An alternative procedure has been included to delineate some options. Figure 3-1 should supplement the text.

\section{Cold End Fabrication}

\section{A. Fabrication Procedure for Sub-Assembly No. 1}

1. Reference

- Diffusion bond cold end current straps consisting of seven (7) 1.5 mil copper foils that have been annealed and pre-stamped.

- Bond sub-assemblies (each consisting of 2 end straps, 2 flexible straps, 12 metallized $\mathrm{BeO}$ discs and 12 copper spring retainers) with a $\mathrm{Cu}-\mathrm{Ag}$ braze.

- $\quad$ Sputter a thin coat of $\mathrm{Ag}$ onto the exposed surface of the spring retainers, masking off all other surfaces.

2. Alternative

- Diffusion bond current straps as in reference procedure.

- Electroplate the spring retainers with Ag.

- Bond sub-assemblies as in reference procedure.

B. Fabrication Procedure for Sub-Assembly No. 2

1. Reference

- Diffusion bond flexible followers, consisting of fourteen (14) 1.5 mil copper foils that have been annealed and pre-cut.

- Drill holes for spring retainers into the followers.

- Sputter a thin coat of Ag onto predesignated portions of each side of the followers.

- Drill tapered pin holes into the tips of the rails.

- Coat the cold frame segments with .5 mils of electroless $\mathrm{Ni}$.

- Electroplate the segments with 1.0 mil of $\mathrm{Sn}$, then etch it away everywhere except on the undersides and on the tips of the rails.

- Apply a thin film of $\mathrm{Pb}-\mathrm{Ag}$ solder to the tips of the rails and to the sputtered portion of the undersides of the followers. 
- Bond the followers to the rails, two followers at a time, with a special bonding fixture.

- Drive Cu ring-shank nails through the center of the followers and into the pin holes in the rails, using a special template for alignment.

- Bend the followers into their design configuration.

2. Alternative

- Ultrasonically bond flexible followers.

- Ultrasonically bond the followers to the tips of the rails.

- Drill holes for spring retainers through the followers.

- Drill tapered pinholes through the center of the followers and into the rails.

- Drive Cu ring-shank nails into the pinholes.

- Sputter a thin coat of $\mathrm{Ag}$ around the spring retainer holes on the topsides of the followers.

- Bend the followers into their design configuration.

Comment: There are two options on the cold end interface configuration for this procedure. A $1.0 \mathrm{mil}$ tin foil at the interface is consistent with the above procedure. Also, by adding a preliminary step, the reference design could be implemented.

C. Joining the Two Sub-Assemblies

1. Reference

- Using the spring retainers as the alignment tooling, set sub-assembly 1 onto subassembly 2, incorporating annular preforms of $\mathrm{Pb}-\mathrm{Sn}$ - $\mathrm{Ag}$ solder between the spring retainers and the followers.

- Clamp and bond the two sub-assemblies with a special fixture.

2. Alternative

- Same as reference procedure except pre-apply the $\mathrm{Pb}-\mathrm{Sn}-\mathrm{Ag}$ solder directly to the individual sub-assemblies rather than use preforms. 


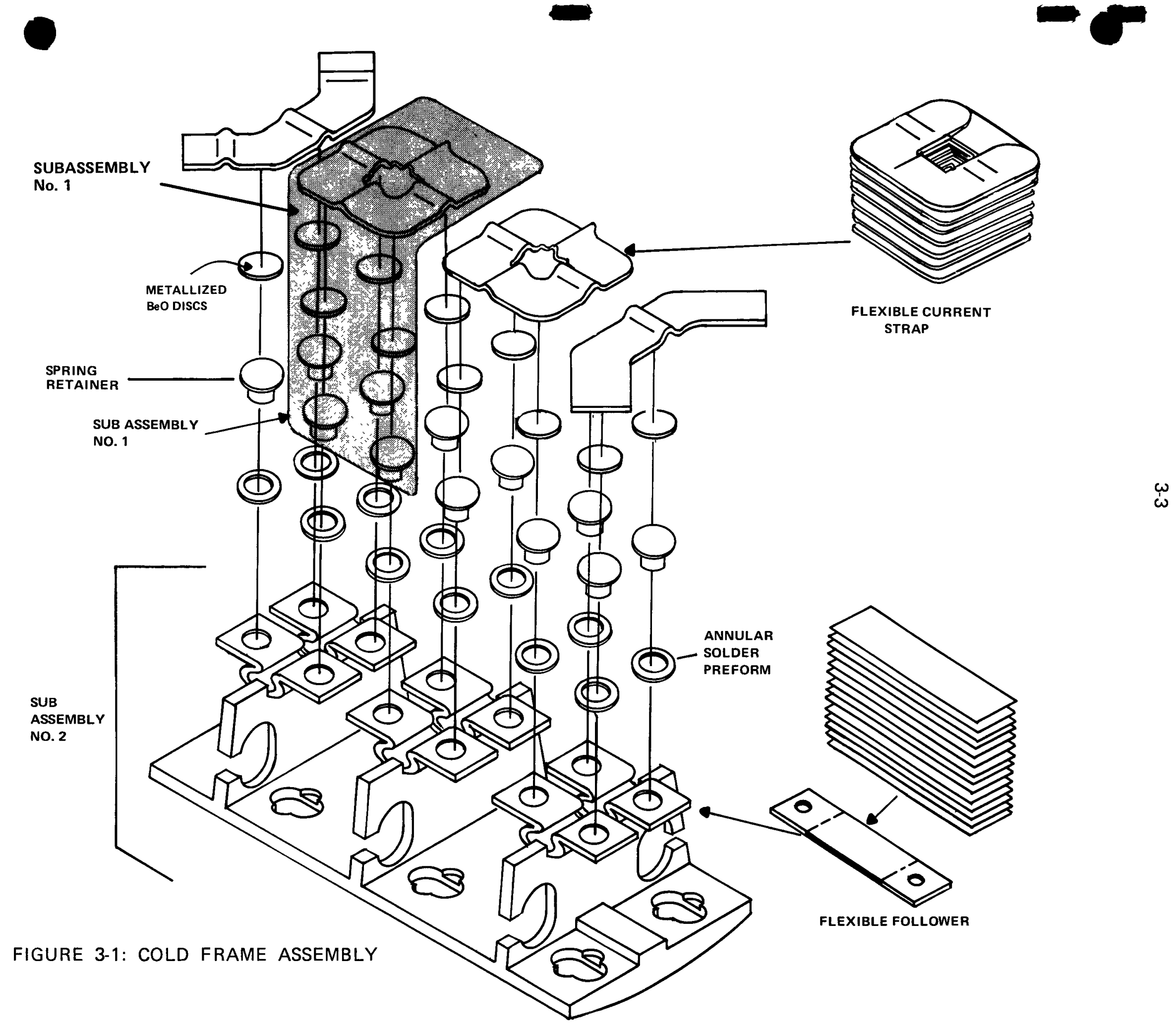




\section{$4-1$ \\ ATTACHMENT 4 \\ Compliant Follower Spring Force}

Tests were undertaken on the compliant followers to determine the spring force for deflection. The tests were done on a Chatillon Spring Tester and the deflection was measured by an optical comparator.

The results are presented in the form of the following which graphs can be summarized as:

Figure 41, 4-2, 4-4 - typical followers displaced and returned to original position to show hysteresis.

Figure 4-3 - typical follower put through a cycle of displacement in the position $y$ (Figure 4-6), negative $y$, and returned to original position.

Figure 4-5 - oxidized follower displaced and returned to original position.

Figure 47, 4-8 - typical followers bonded to rail displaced and returned to originat position.

Note: Tension is positive, compression is negative, and the directional sign follows Figure 46. 
Follower \#1

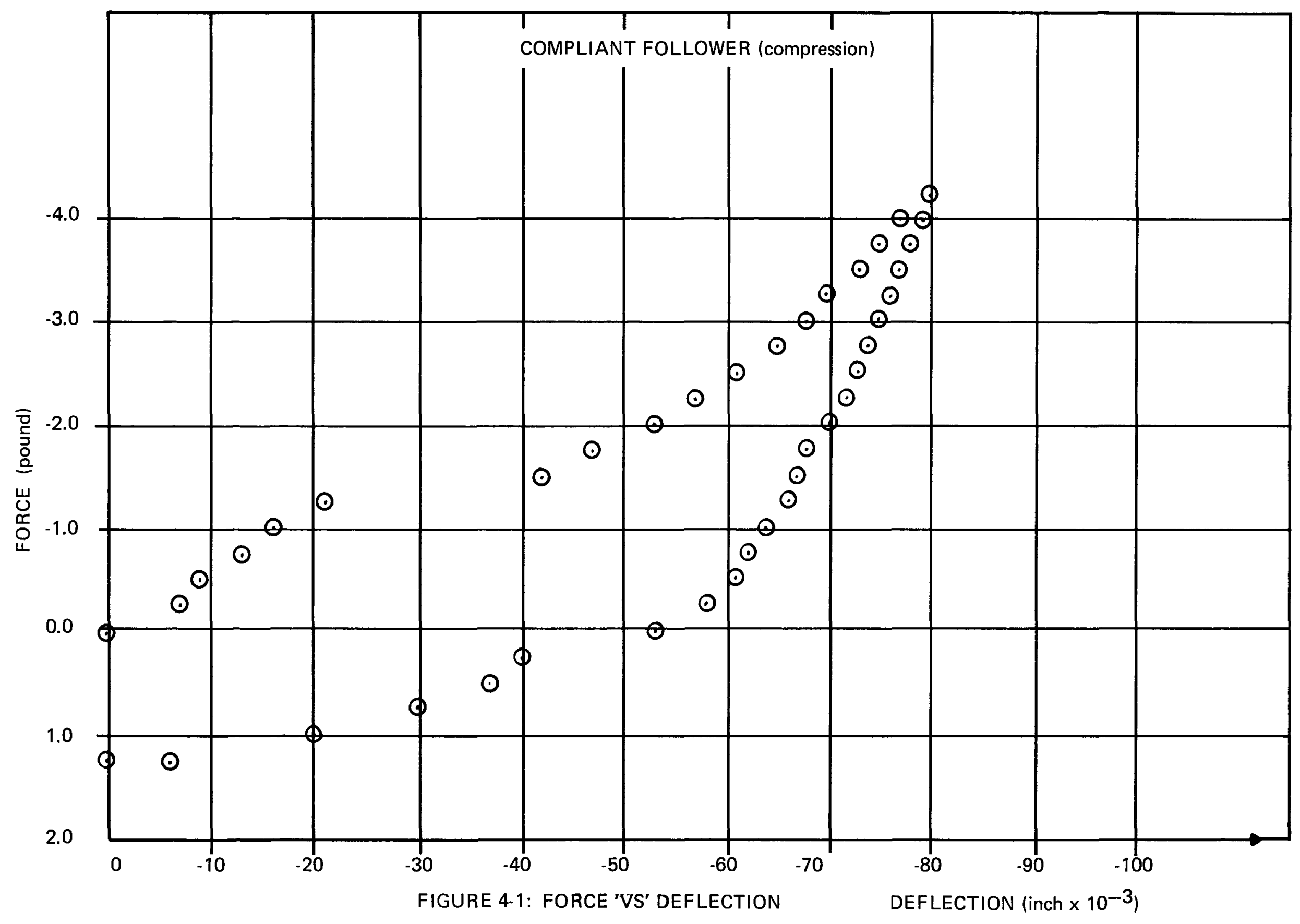


follower \#1

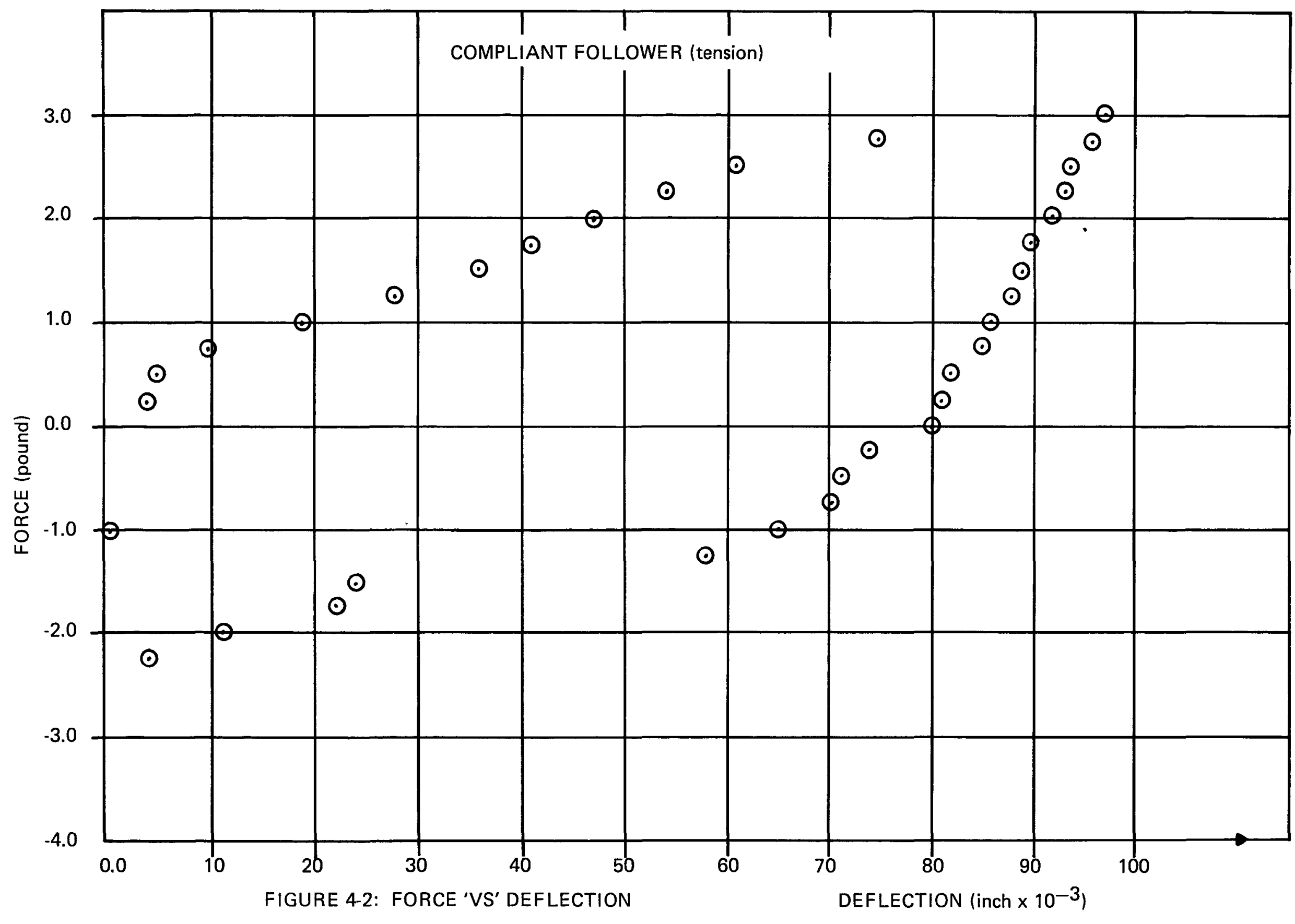




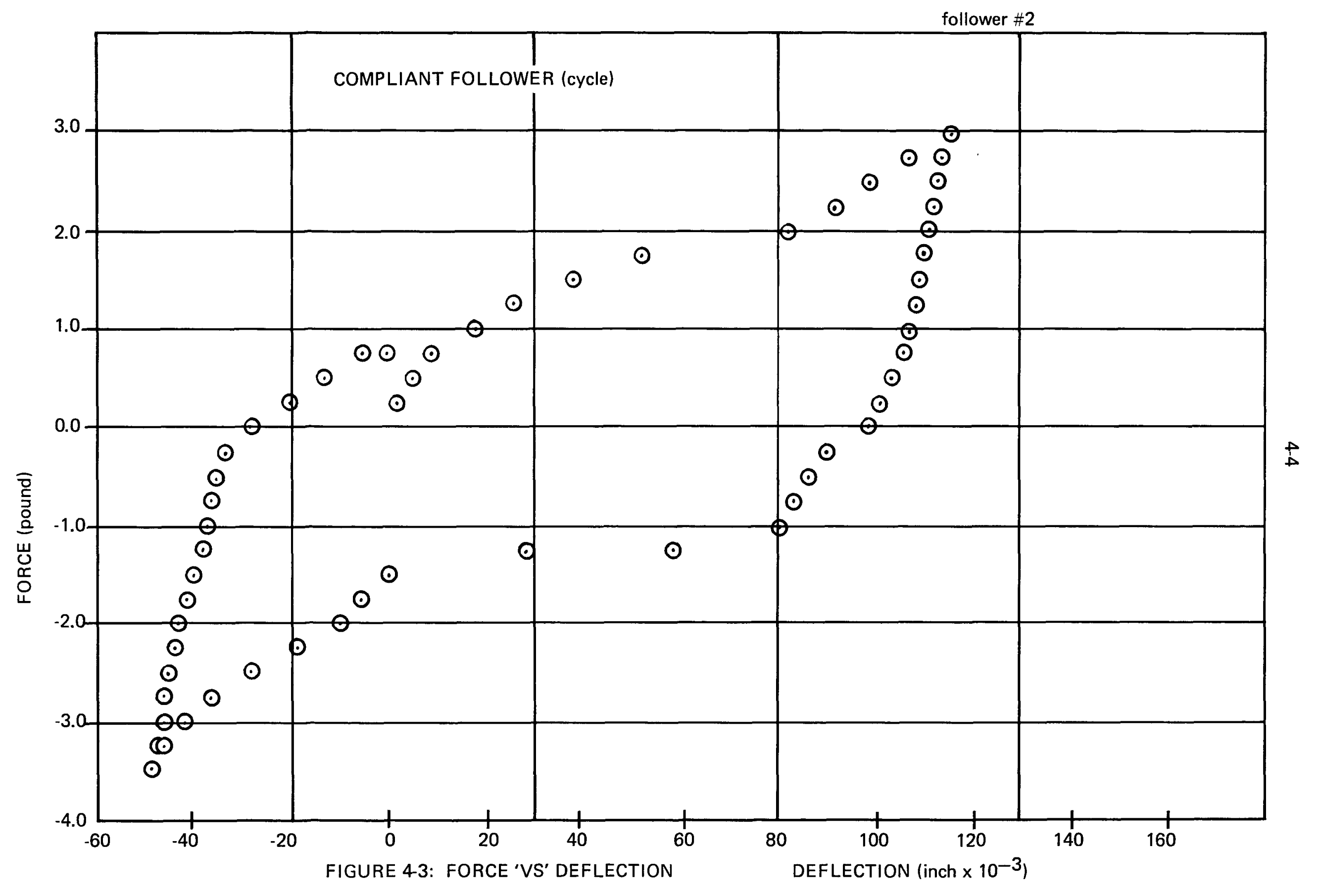




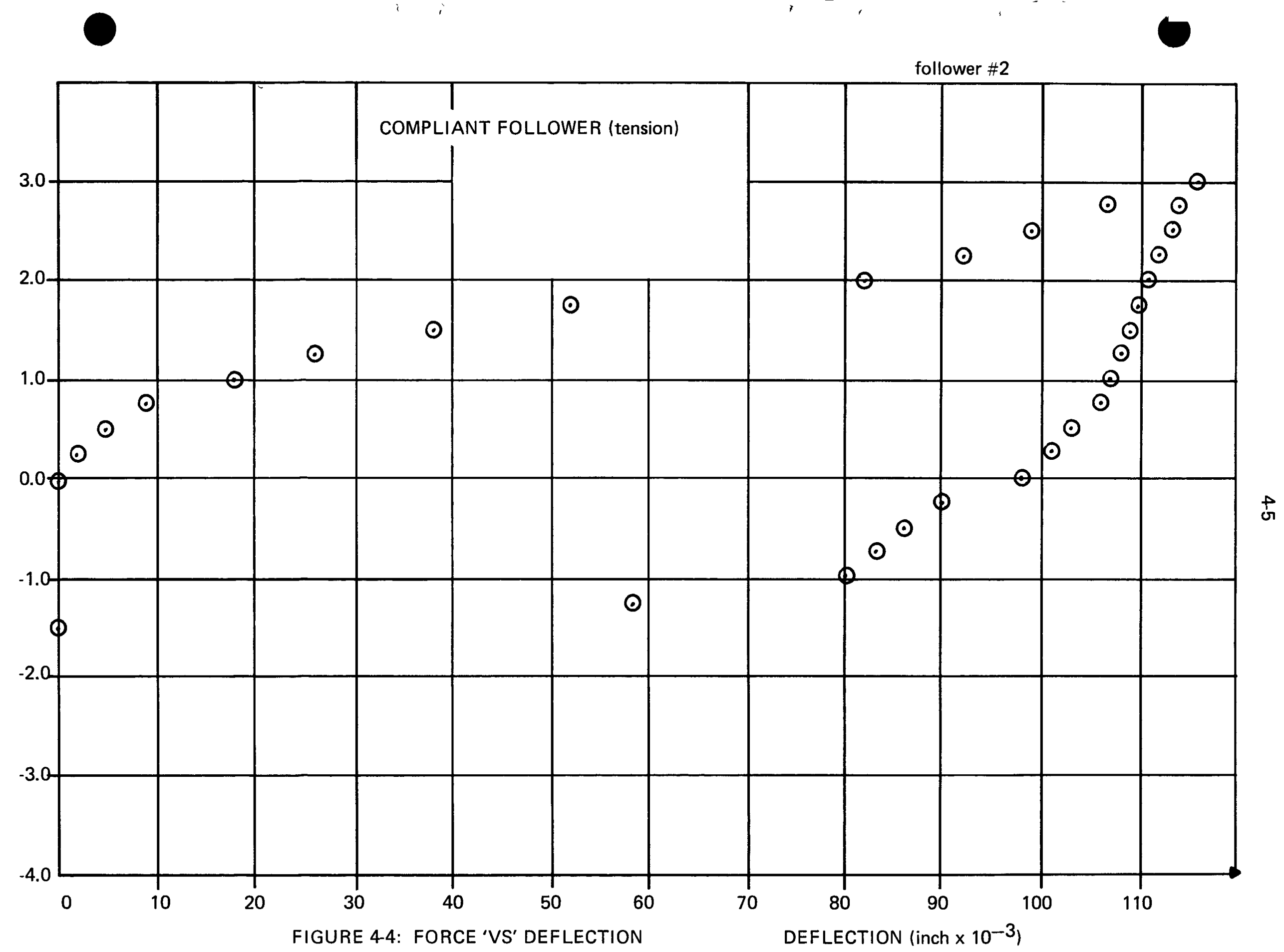




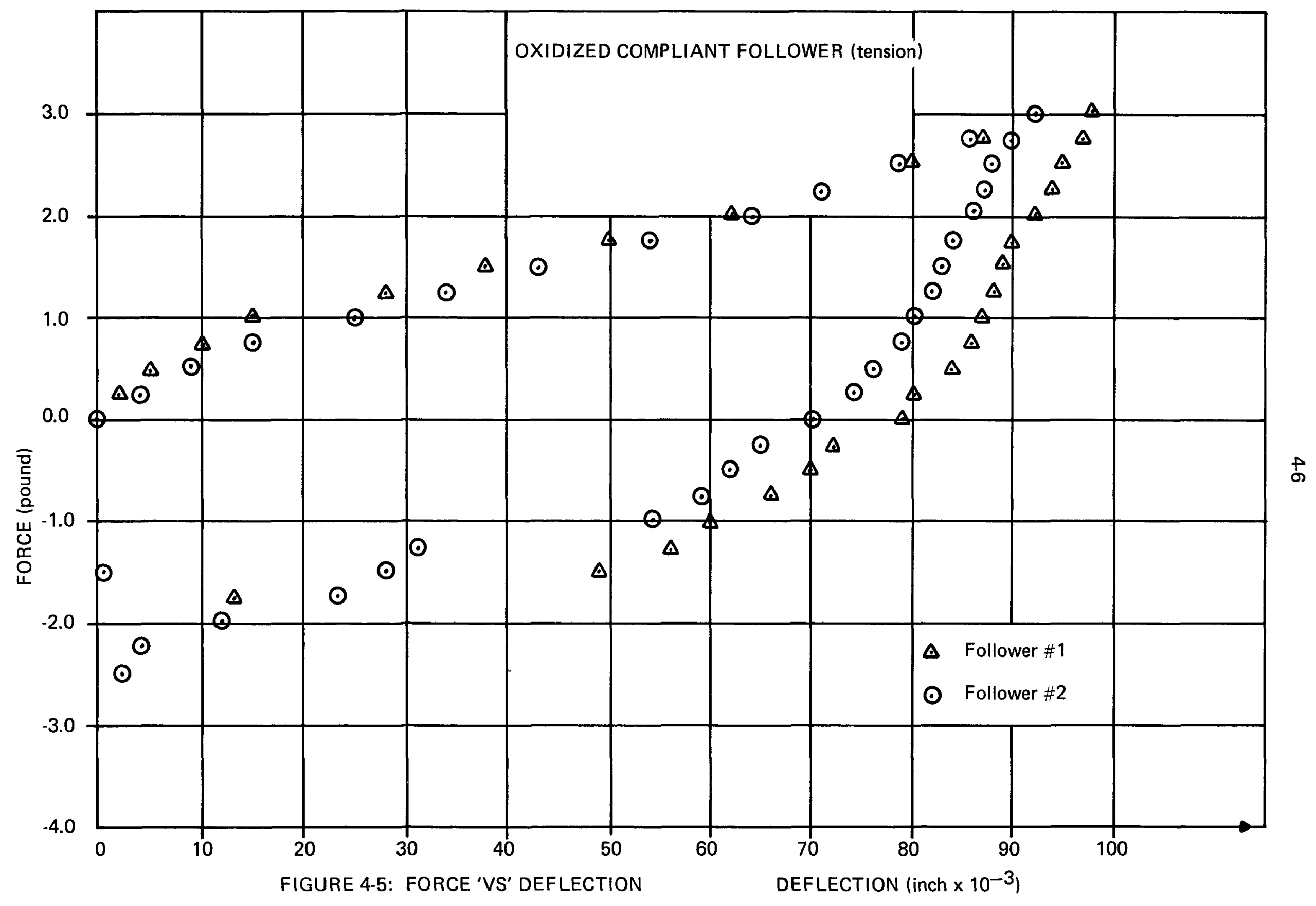




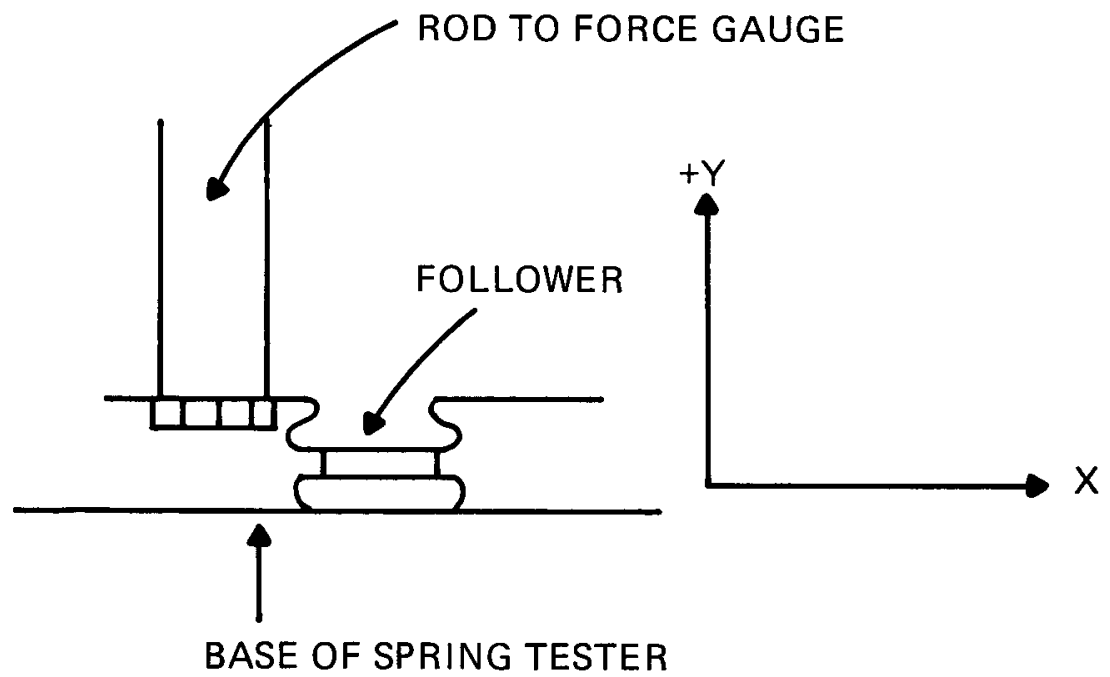

FIGURE 4-6 


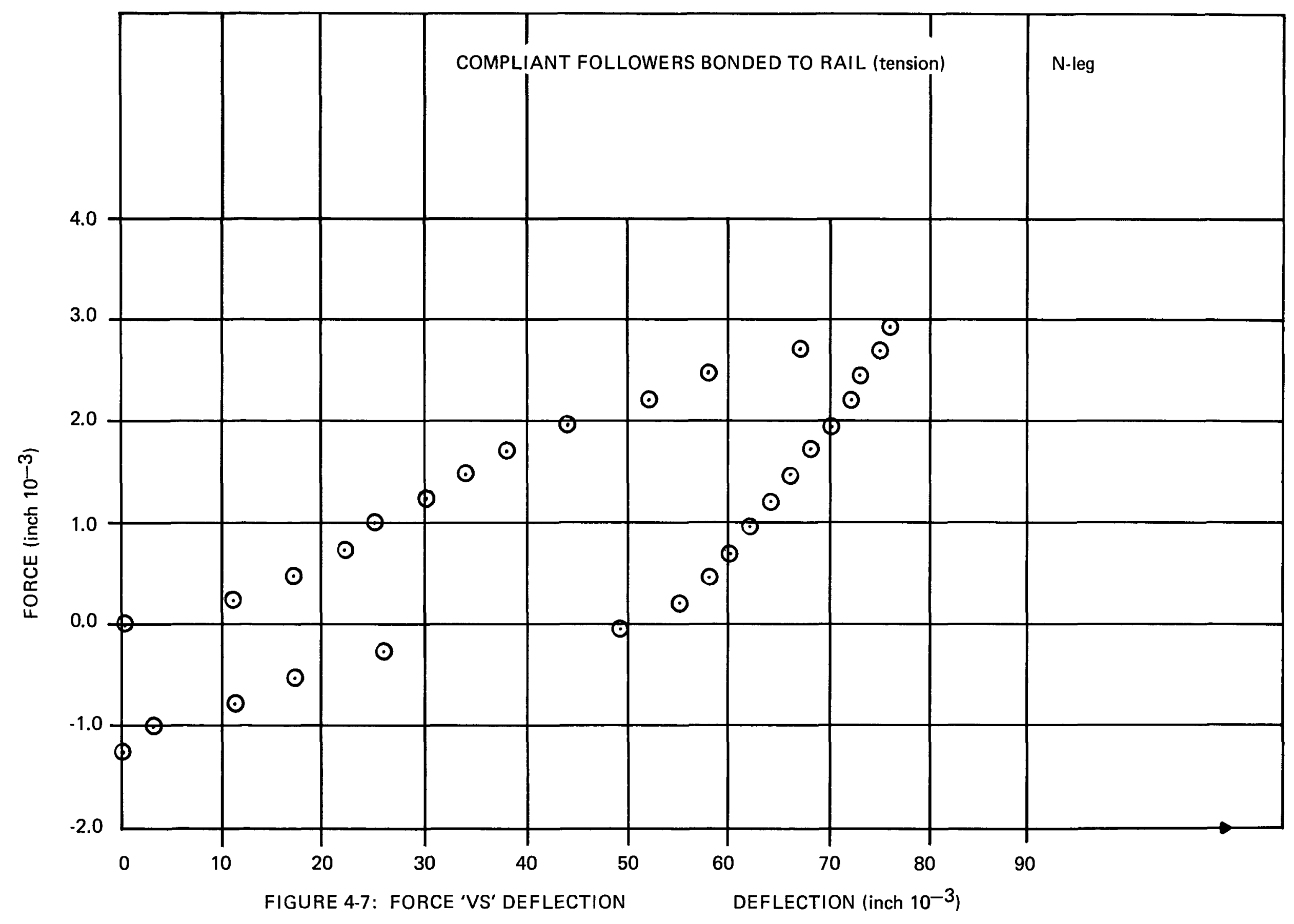




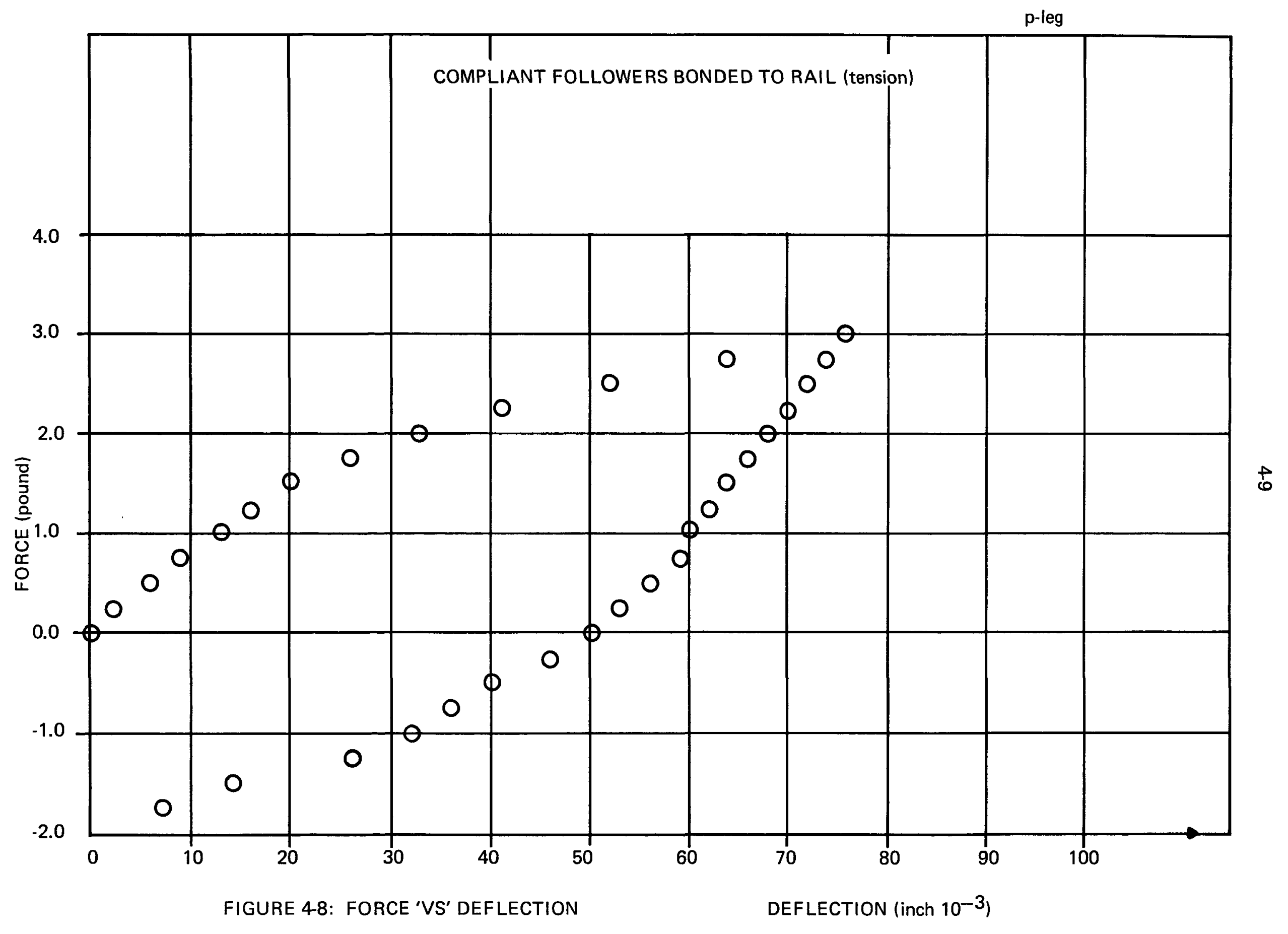




\section{ATTACHMENT 5}

\section{Cold End Hardware Spring Force}

A 6-couple cold end hardware assembly with bonded compliant followers was fabricated and a spring force test performed. The results are attached in the form of graphs and can be summarized as:

Figure 5-1, 5-2 - Cold straps displaced and returned to original position.

Figure 5-3, 5-4 - Current strap displaced and returned to original position.

Note: Tension is positive and compression is negative. 


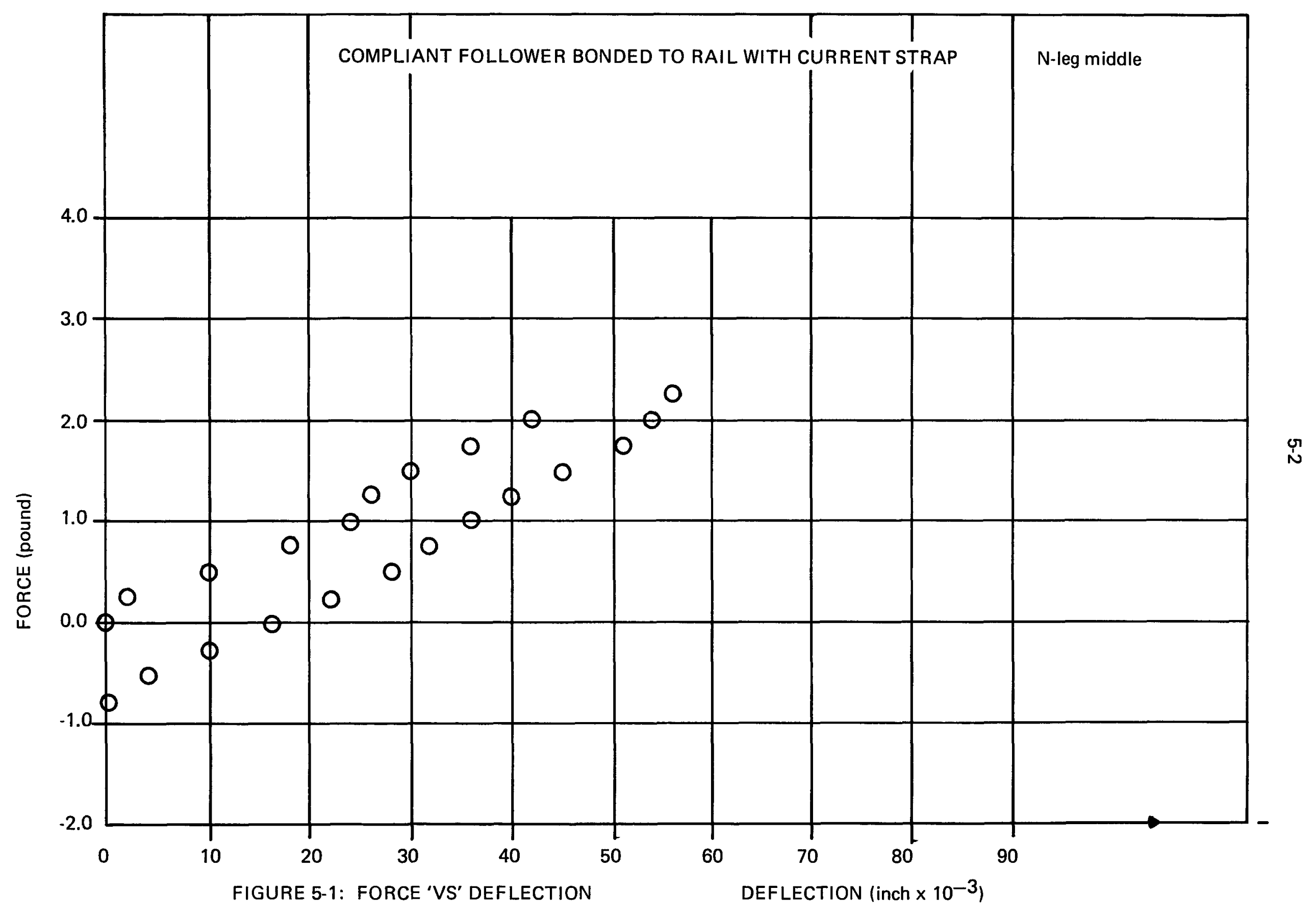




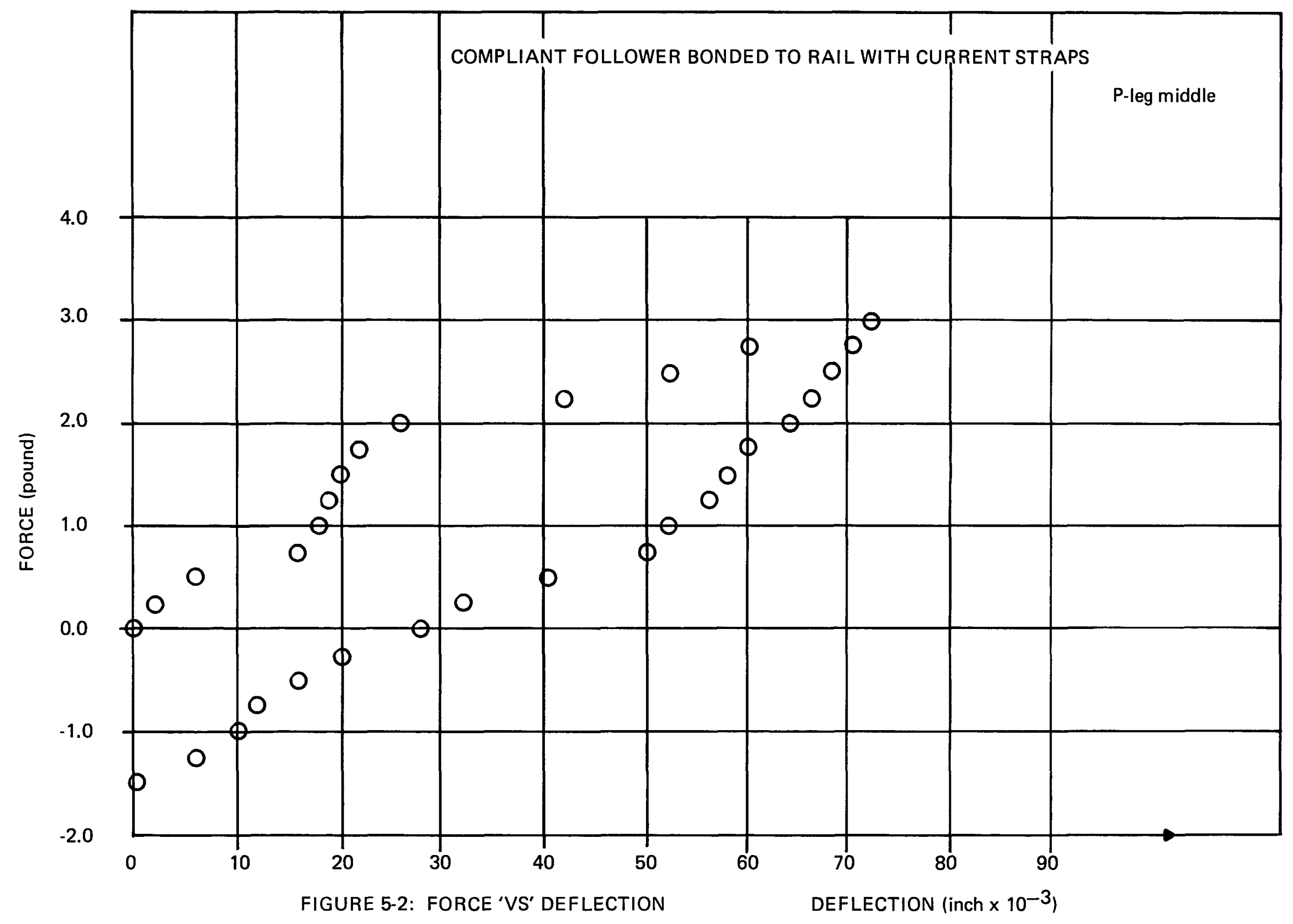




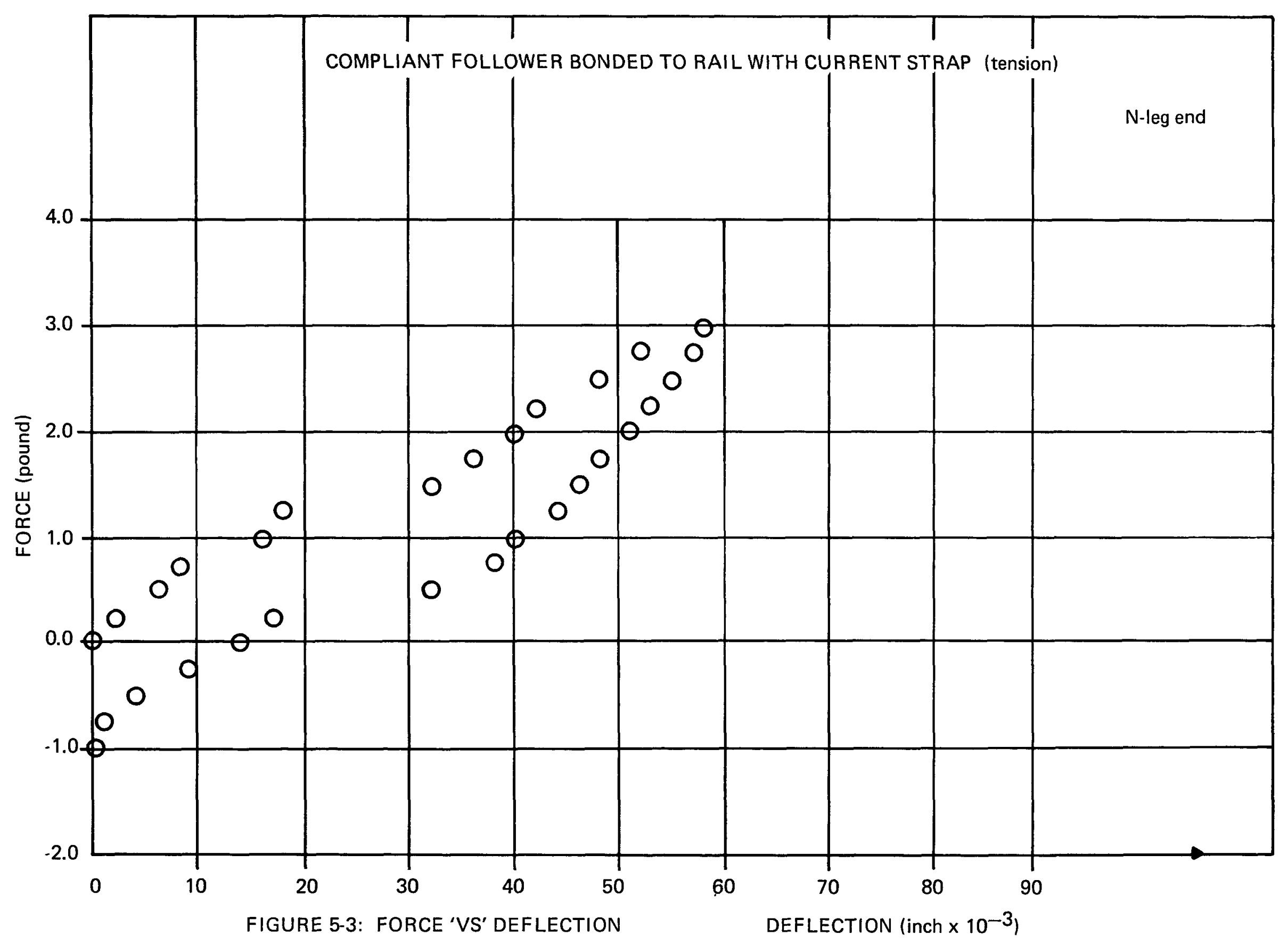




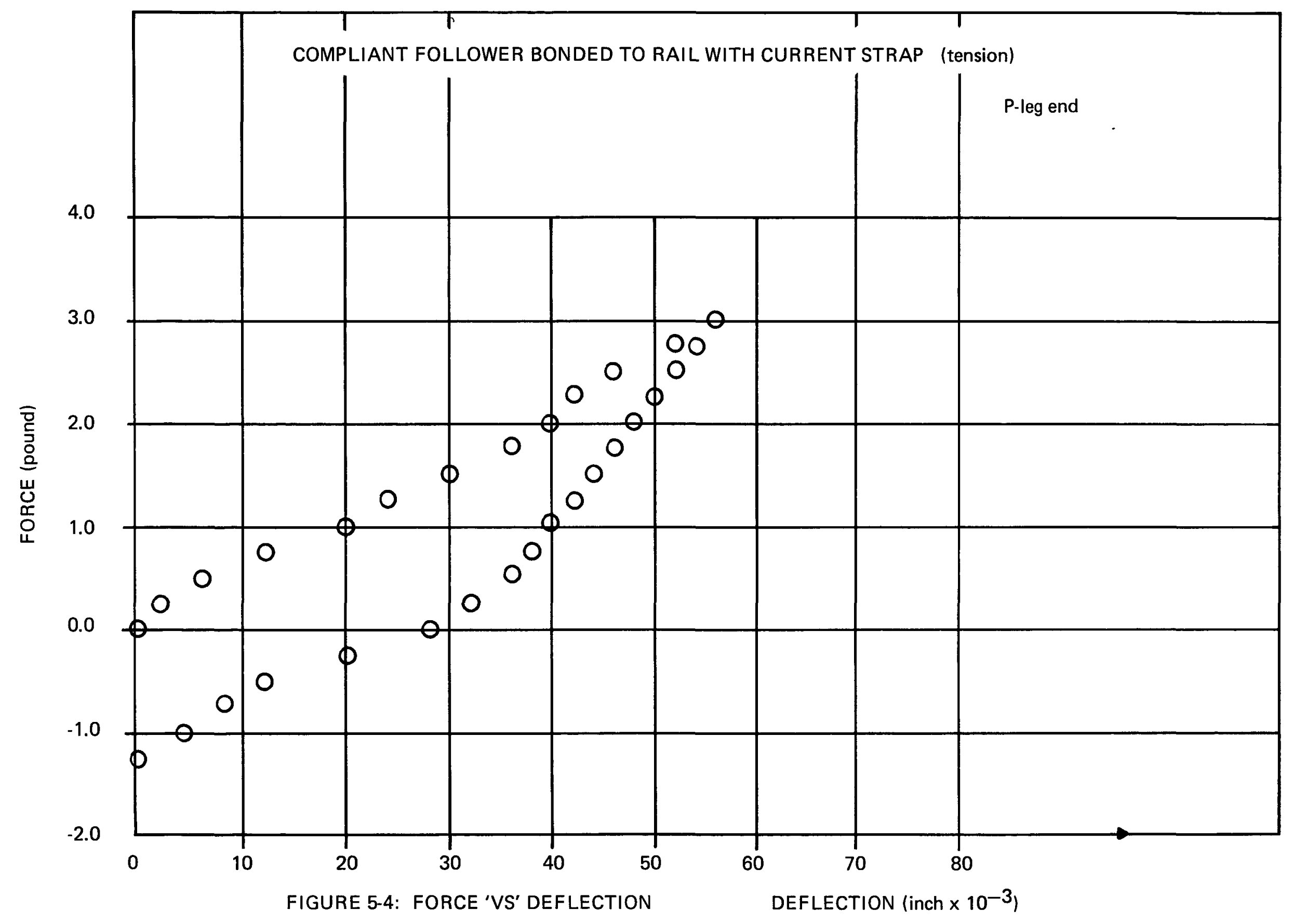




\section{ATTACHMENT 6 \\ Determination of Stress on $\mathrm{N}$ and P-legs}

\section{Introduction:}

With the increased number of modifications being done on the cold frame assembly, there is becoming a need for analysis of the mechanical behavior of these assemblies. The main area that needs to be examined is the change in stress on the legs as sublimation, creep, thermal expansion, etc., take place. This stress should be known because a low stress could cause high resistance or damage to the leg during dynamic loading, and a high stress could cause the leg to crack.

This attachment describes how the stress changes as the follower changes position. The method by which the deflection occurred will not be examined, so these results can be applied to any condition.

\section{Procedure:}

The stress on the legs is a combination of spring force, insulation compliance, and restoring force of the hardware. The spring force is the easiest to determine because all that is needed is the spring constant, Figure 6-1, and deflection, while the insulation compliance and hardware force have to be determined experimentally.

The insulation compliance was determined by compressing HiFi paper on the Instron and producing a stress 'vs' strain graph. This was curve fit on a Wang calculator to a 4th order polynominal, Figure 6-2.

Hardware force information was obtained by putting the hardware through a loading cycle on a spring tester, and measuring the force for deflections. This data is presented in the form of a graph on Figure 6-3.

The tolerances for stack height can greatly effect the initial spring force, so each condition was calculated for the maximum, nominal, and minimum initial spring force. In this way, it can safely be said that the stress would lie within the maximum and minimum curves. The equations used for the calculation of stress are shown in Figure 6-4.

\section{Results:}

The results are in the form of graphs which can be summarized as:

Figures 6-5, 6-6, 6-7, 6-8 Compression stress on the leg as creep or sublimation would take place.

Figures 6-9, 6-10, 6-11, 6-12, 6-13 - Compression stress as thermal expansion takes place.

Figure 6-14 and 6-15-

Illustrates how each component (spring, insulation and hardware) contribute to the stress for a nominal initial spring force. 
6-2

SPRING P1, “P” LEG

TYPE: COMPRESSION

O.D. $=0.211 \pm 0.005$

WIRE DIA. $=0.041$

ENDS: CLOSED, GROUND \& SQUARE WITH O.D. WITHIN 0.004 GROUND AREA AT LEAS̃T 3/4 OF CIRCUMFERENCE

FREE LENGTH (AFTER GRINDING):

$$
0.555 \pm .010
$$

SOLID LENGTH: $0.345 \pm .005$

FORCE AT 0.465 LENGTH = 8.5 LB.

$$
\pm 0.5 \text { LB. }
$$

DIRECTION OF COILS: R.H.
SPRING P2, "N" LEG

TYPE: COMPRESSION

O.D. $=0.282 \pm 0.005$

WIRE DIA. $=0.056$

ENDS: CLOSED, GROUND \& SQUARE WITH O.D. WITHIN 0.004 GROUND AREA AT LEAST 3/4 OF CIRCUMFERENCE

FREE LENGTH (AFTER GRINDING):

$$
0.555 \pm .010
$$

SOLID LENGTH: $0.376 \pm .005$

FORCE AT 0.465 LENGTH $=23.4$ LB. \pm 1.5 LB.

DIRECTION OF COILS: R.H. 


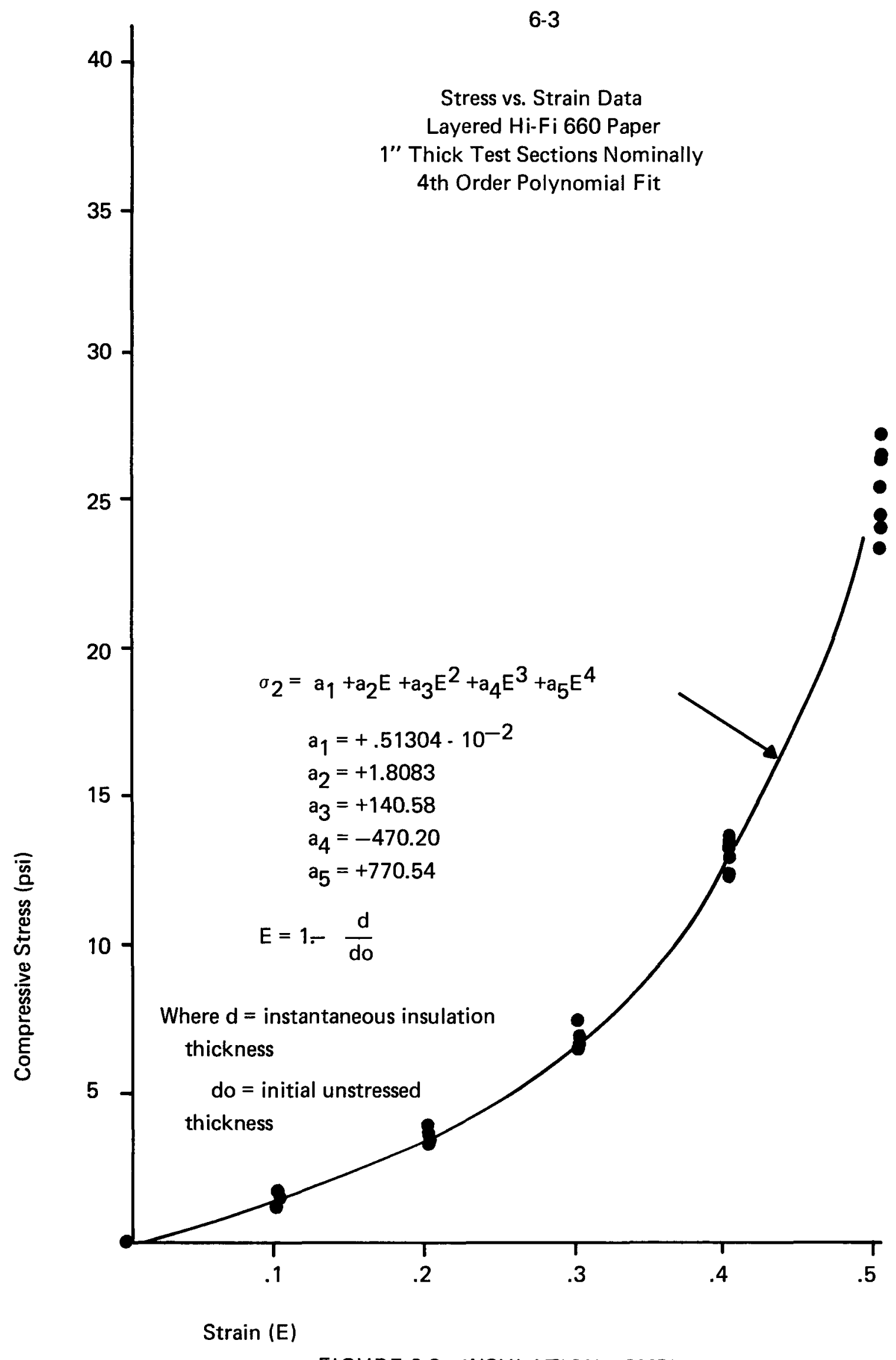

FIGURE 6-2: INSULATION COMPLIANCE 


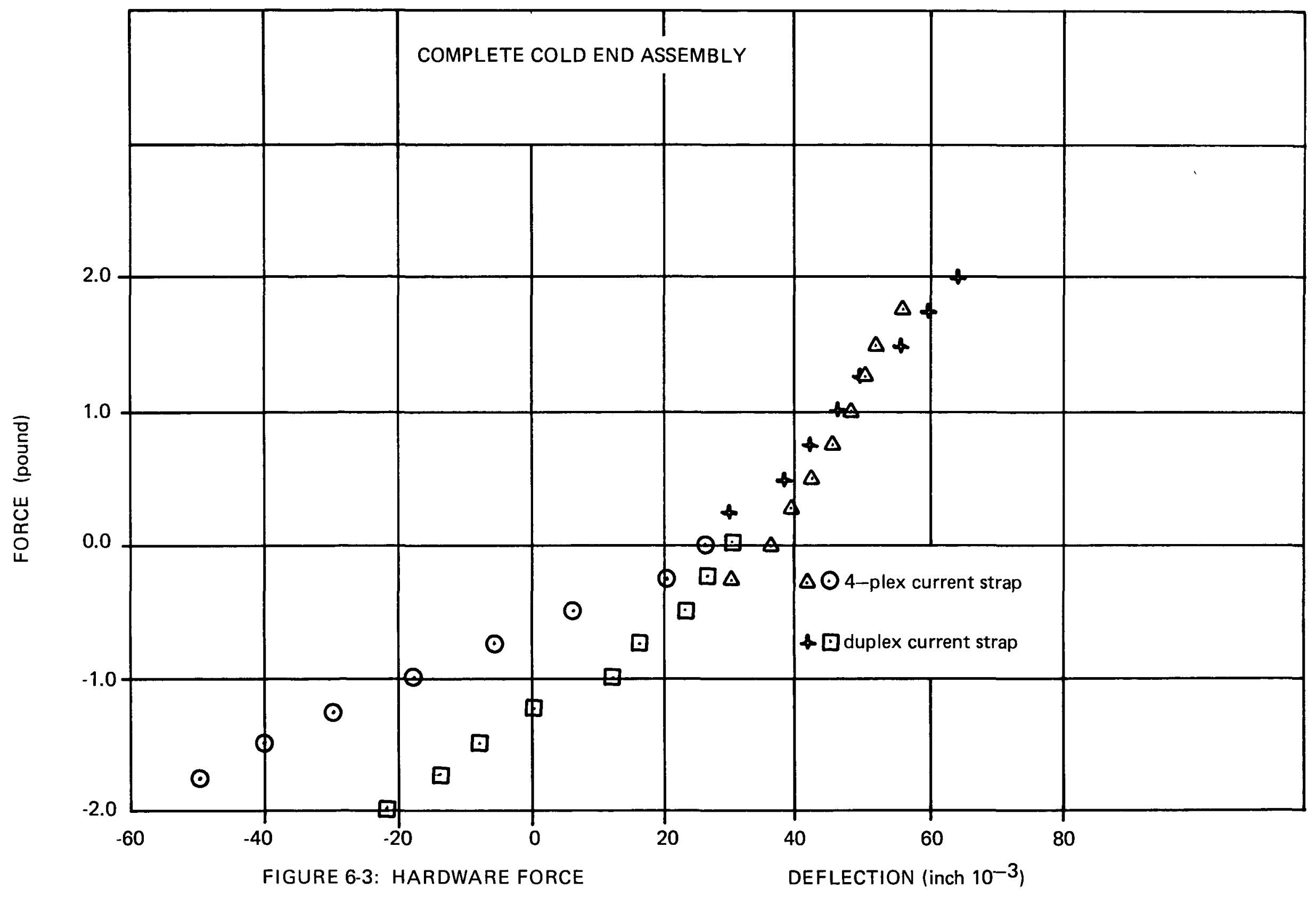


$\mathrm{F}_{\mathrm{TOT}}=\mathrm{Fs}-\mathrm{Fr}=\mathrm{P}_{1}+\mathrm{P}_{2}=\sigma_{1} \mathrm{~A}+\sigma_{2} \mathrm{~A}_{2}$

$\therefore \sigma_{1}=\frac{1}{A_{1}}\left[\mathrm{Fs}-\mathrm{Fr}-\sigma_{2} \mathrm{~A}_{2}\right]$

where Fs $=F s i-K(L-L i)$

$\sigma_{2}=a_{1}+a_{2} E_{1}+a_{3} E^{2}+A_{4} E_{1}^{3}+a_{5} E_{1}^{4}$

where $E=1-\frac{L}{L o}$

$$
\begin{aligned}
& a_{1}=+.51304 \times 10^{-2} \\
& a_{2}=+1.8083 \\
& a_{3}=+140.58 \\
& a_{4}=470.20 \\
& a_{5}=+770.54
\end{aligned}
$$

Fr is obtained from Figure 3

\section{LIST OF VARIABLES}

$\begin{array}{ll}\mathrm{Fs} & \text { Spring Force } \\ \mathrm{Fr} & \text { Strap-Followers restoring Force } \\ \sigma_{1}, \mathrm{P}_{1} & \text { Stress, Force on Leg } \\ \sigma_{2}, \mathrm{P}_{2} & \text { Stress, Force on Insulation } \\ \mathrm{A}_{1}, \mathrm{~A}_{2} & \text { Cross-sectional Area of Leg, Insulation } \\ \mathrm{Li} & \text { Initial Leg Length } \\ \mathrm{Lo} & \text { Unstressed Insulation Layer Thickness } \\ \mathrm{K} & \text { Spring Constant } \\ \mathrm{Fsi} & \text { Initial Spring Force } \\ \mathrm{L} & \text { Instantaneous Leg Length }\end{array}$




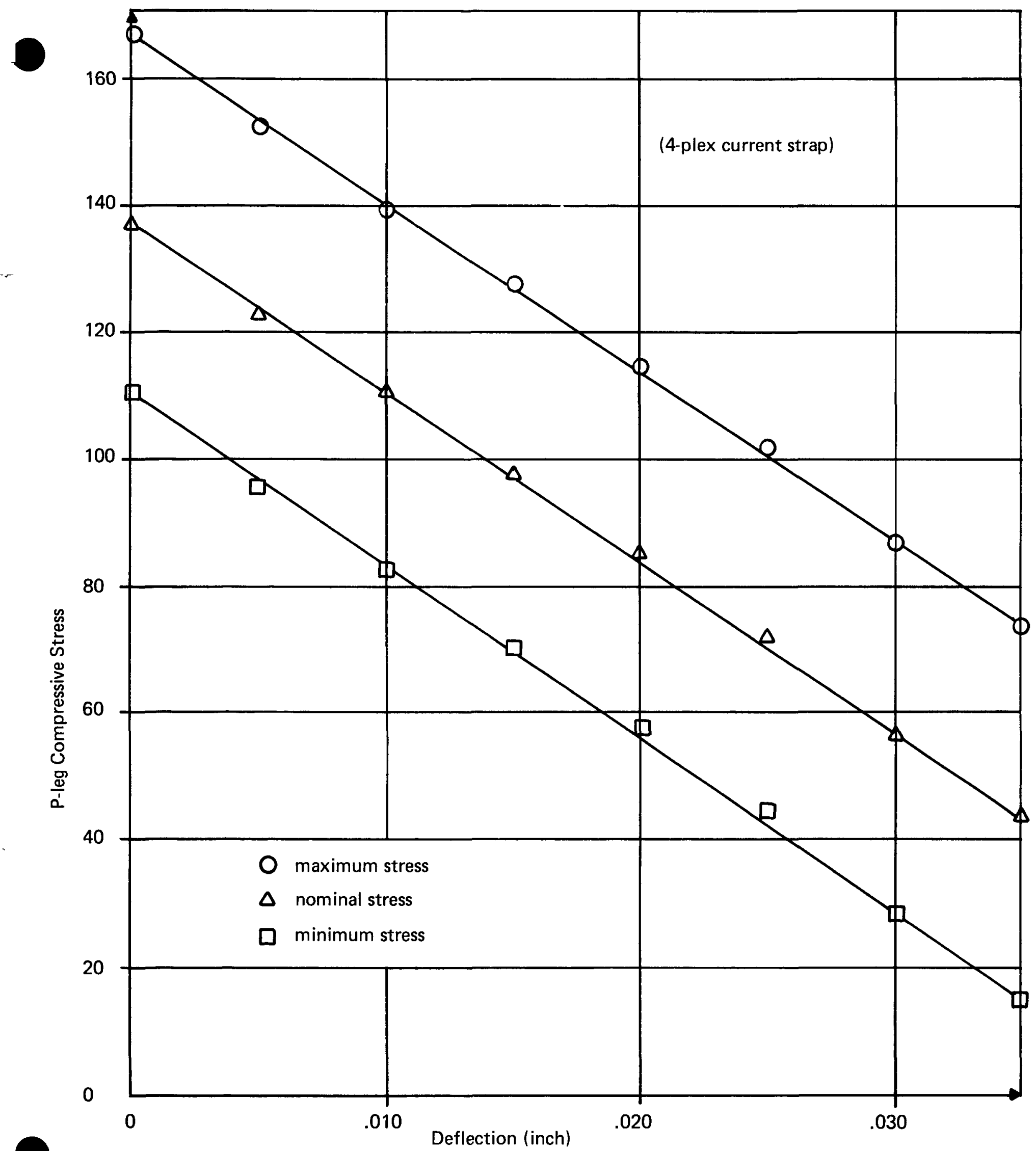

FIGURE 6-5: P-LEG COMPRESSIVE STRESS 'VS' DEFLECTION 
6-7

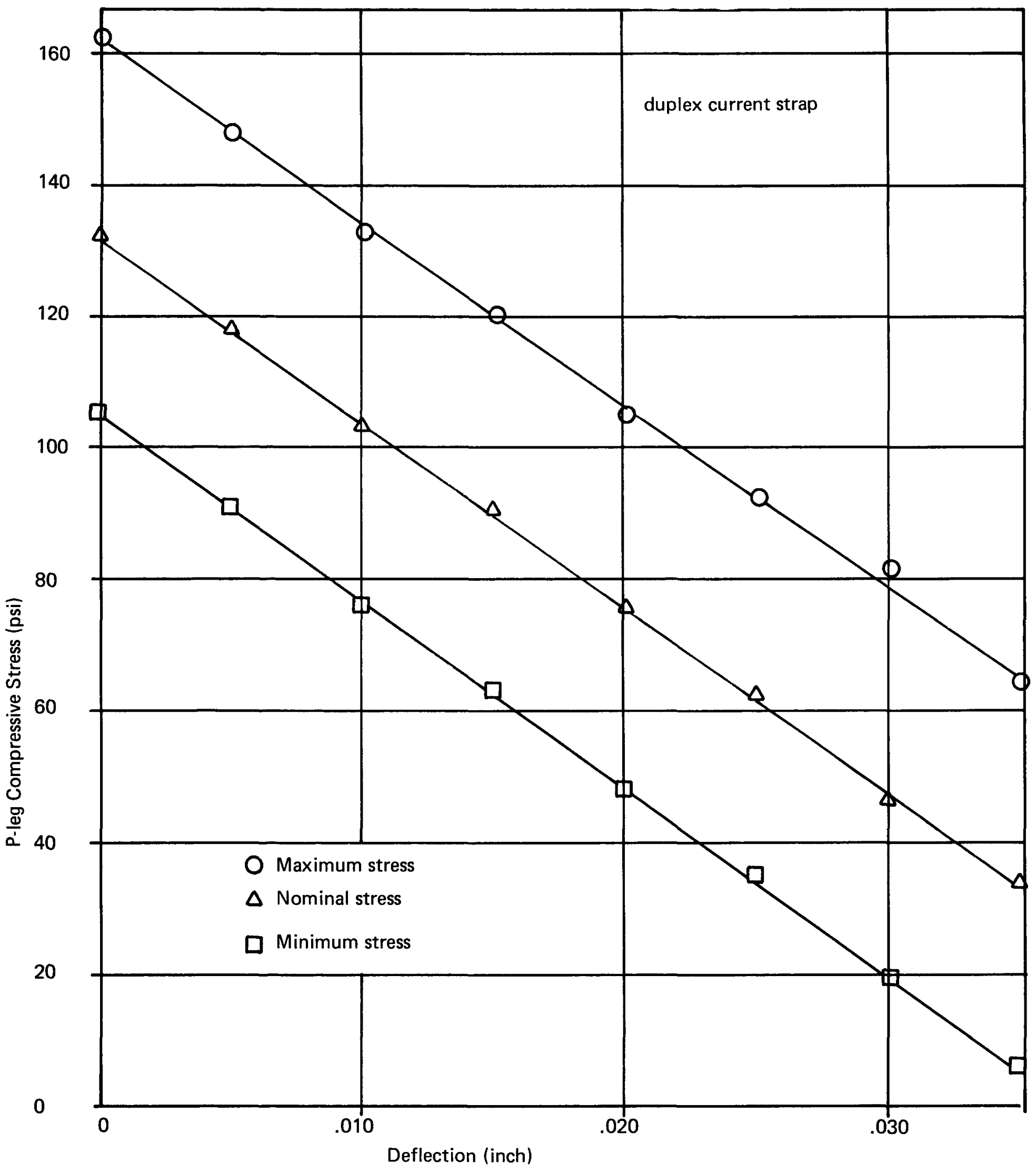

FIGURE 6-6: P-LEG COMPRESSIVE STRESS 'VS' DEFLECTION 
$6-8$

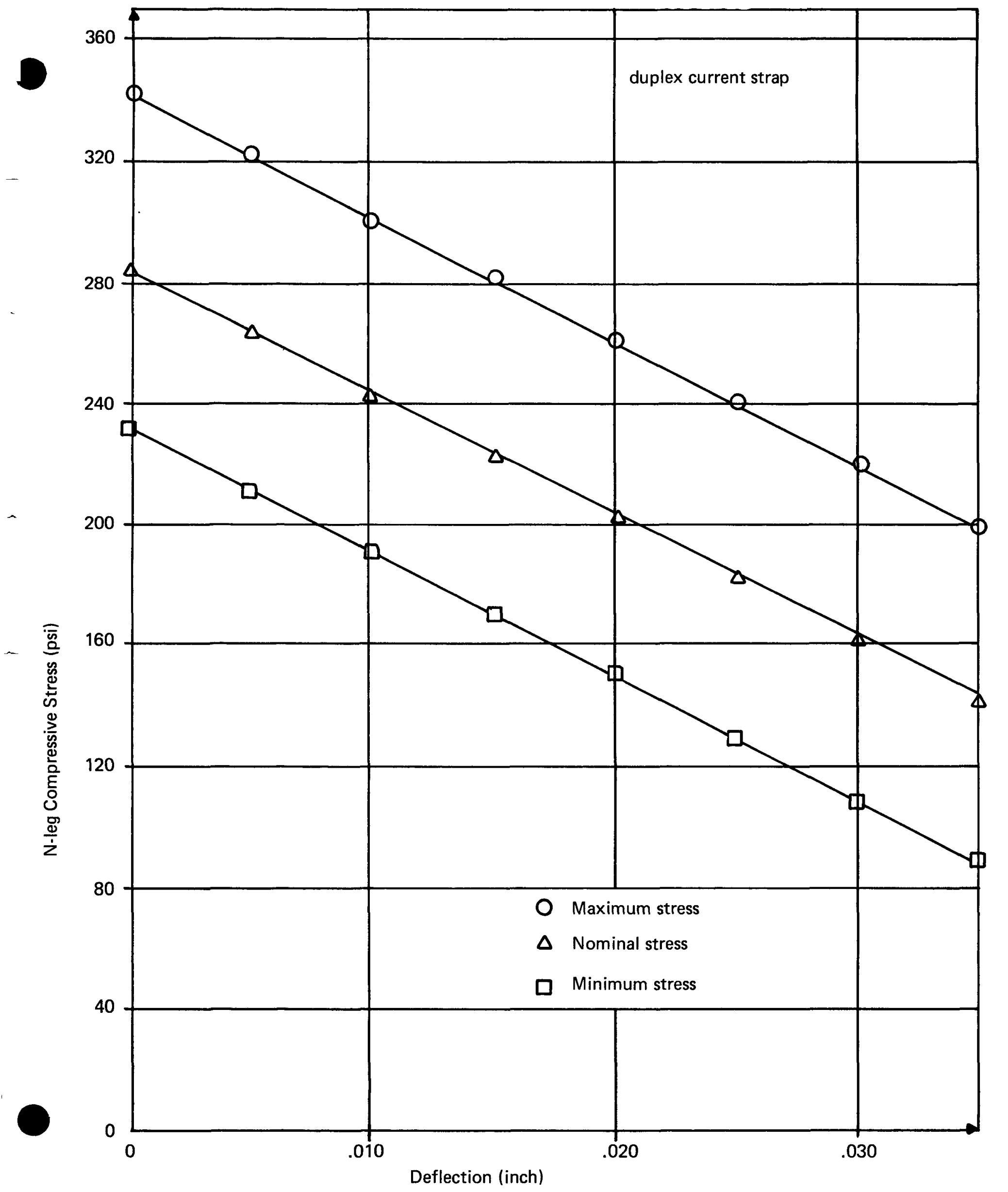

FIGURE 6-7: N-LEG COMPRESSIVE STRESS 'VS' DEFLECTION 


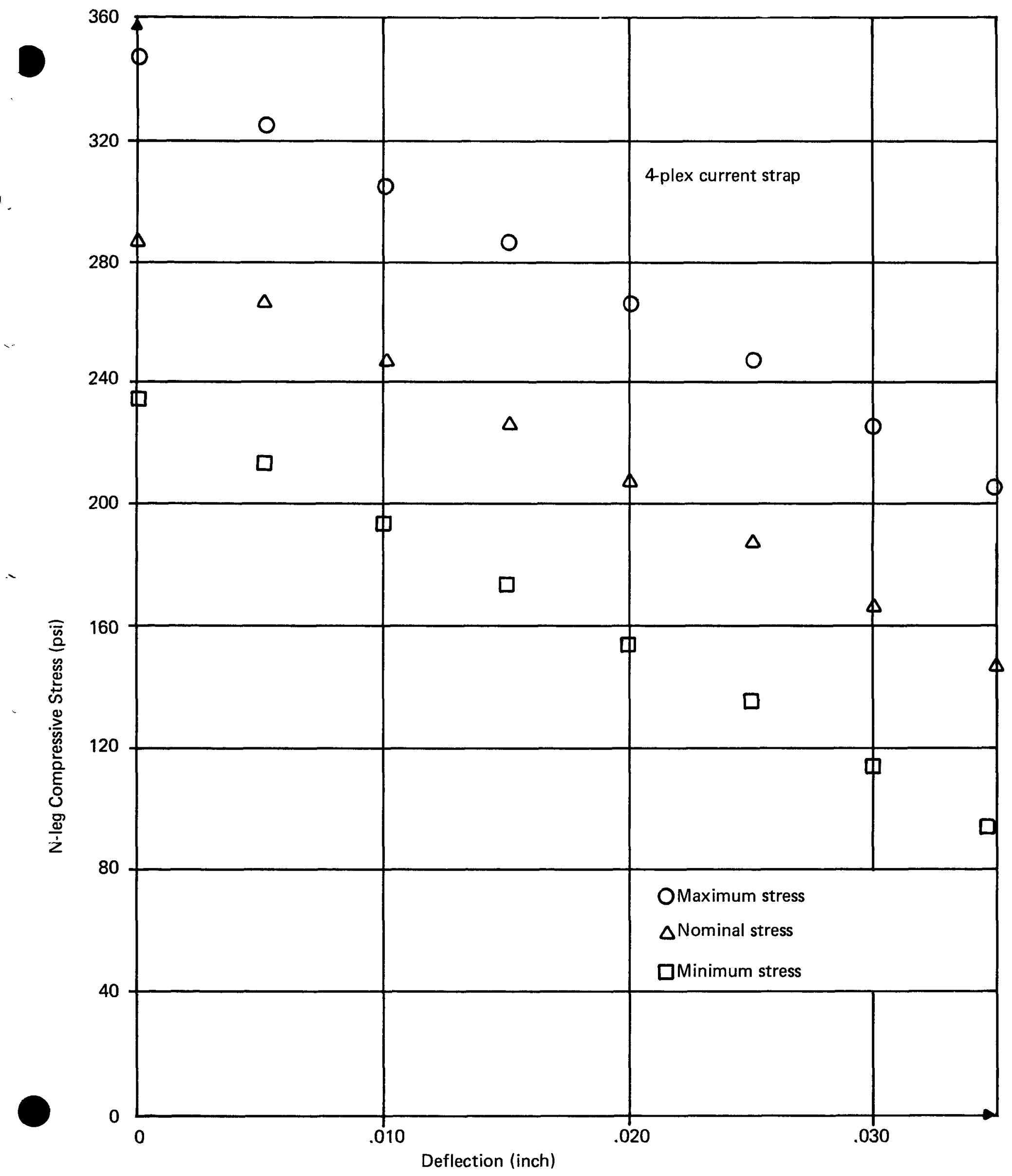

FIGURE 6-8: N-LEG COMPRESSIVE STRESS 'VS' DEFLECTION 
6-10

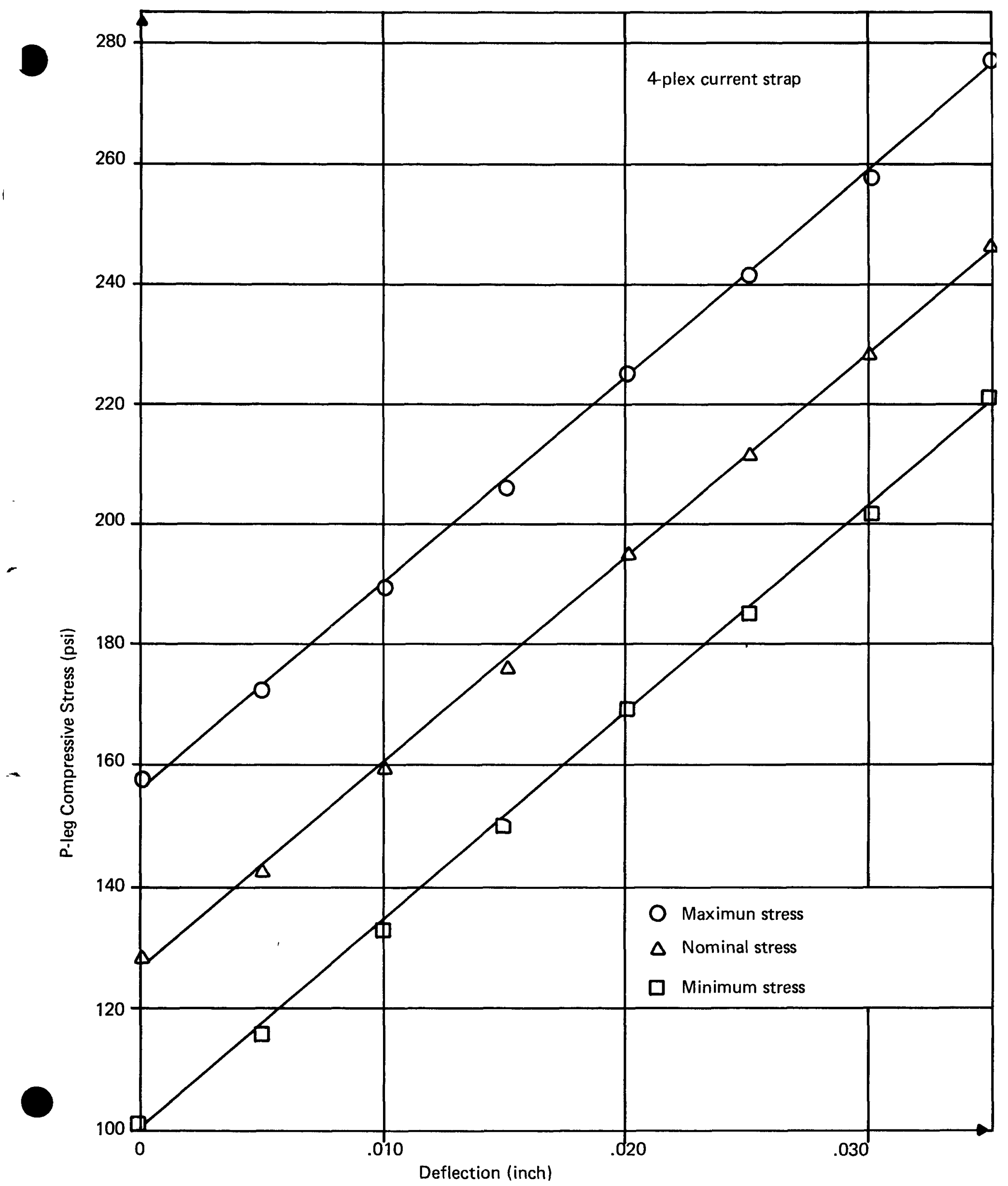

FIGURE 6-9: P-LEG COMPRESSIVE STRESS 'VS' DEFLECTION 


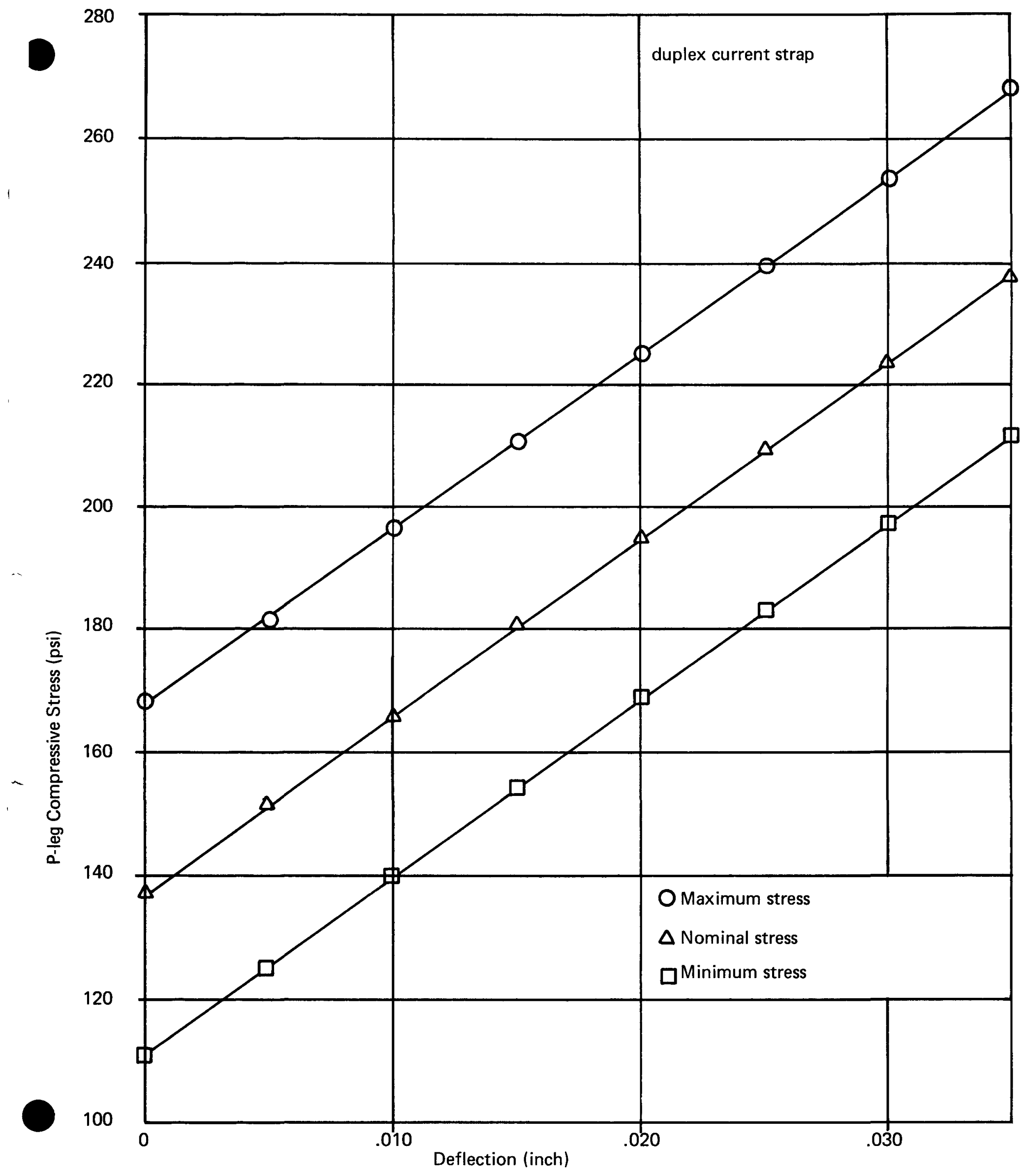

FIGURE 6-10: P-LEG COMPRESSIVE STRESS 'VS' DEFLECTION 


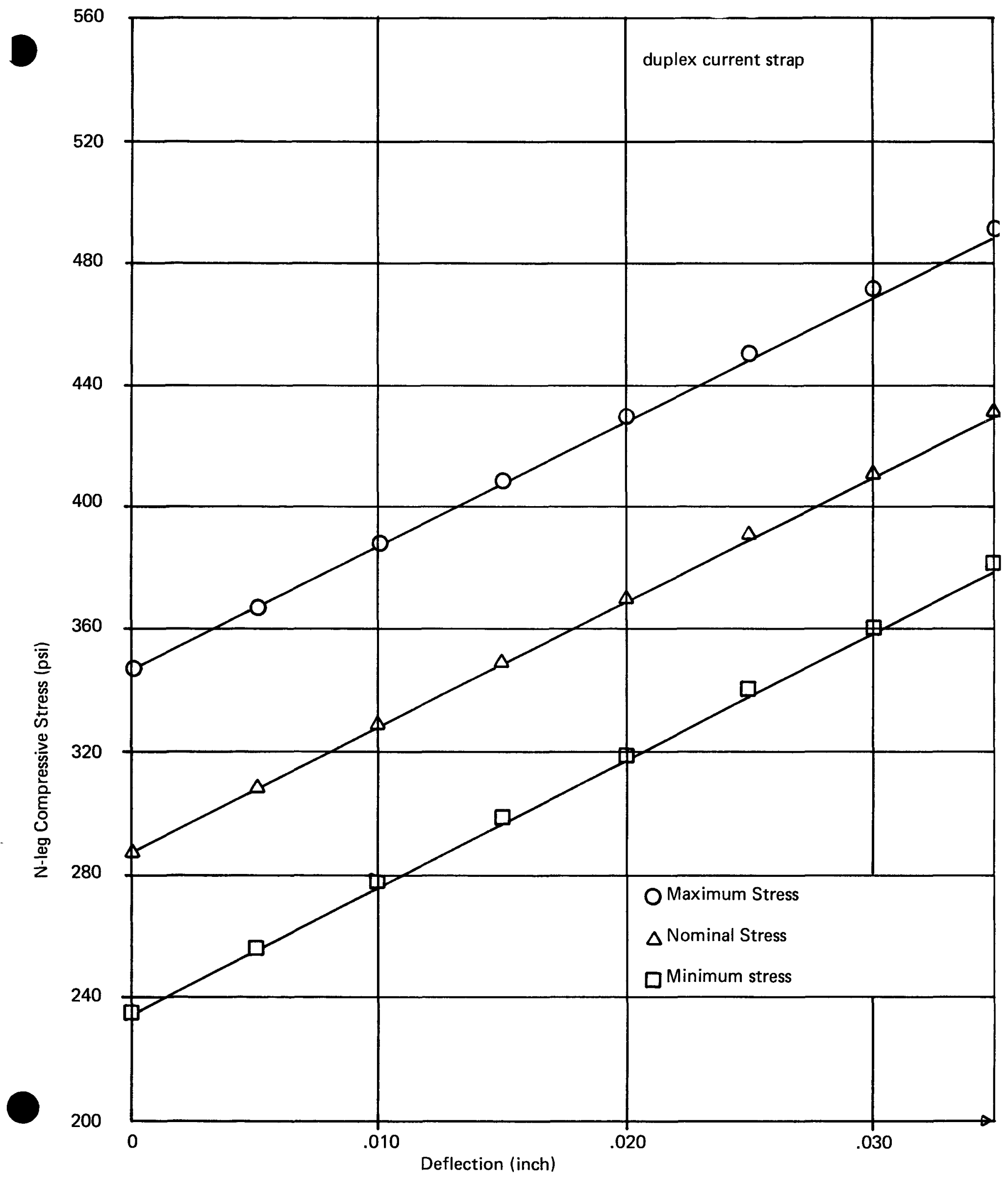

FIGURE 6-11: N-LEG COMPRESSIVE STRESS 'VS' DEFLECTION 
6-13

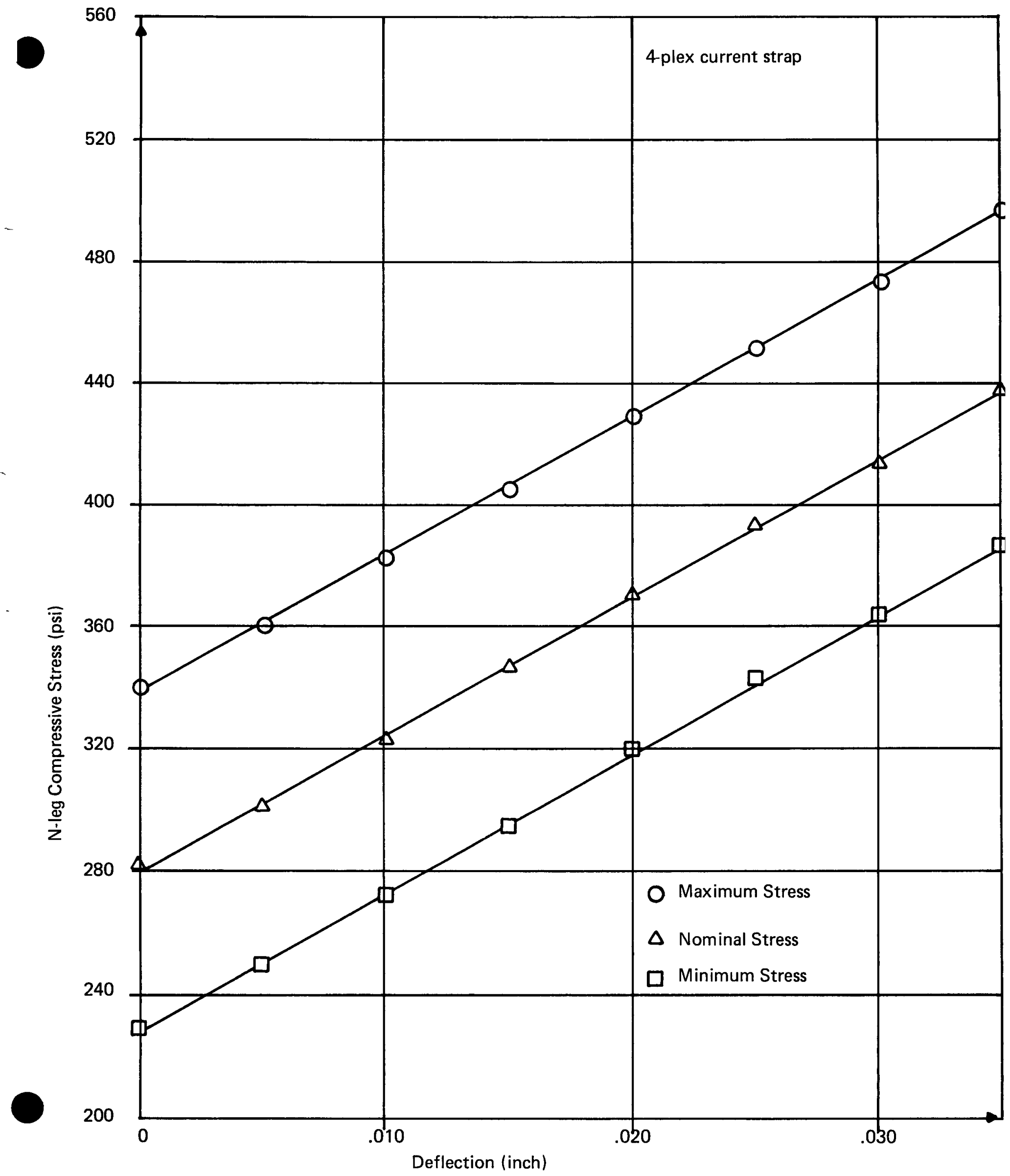

FIGURE 6-12: N-LEG COMPRESSIVE STRESS 'VS' DEFLECTION 


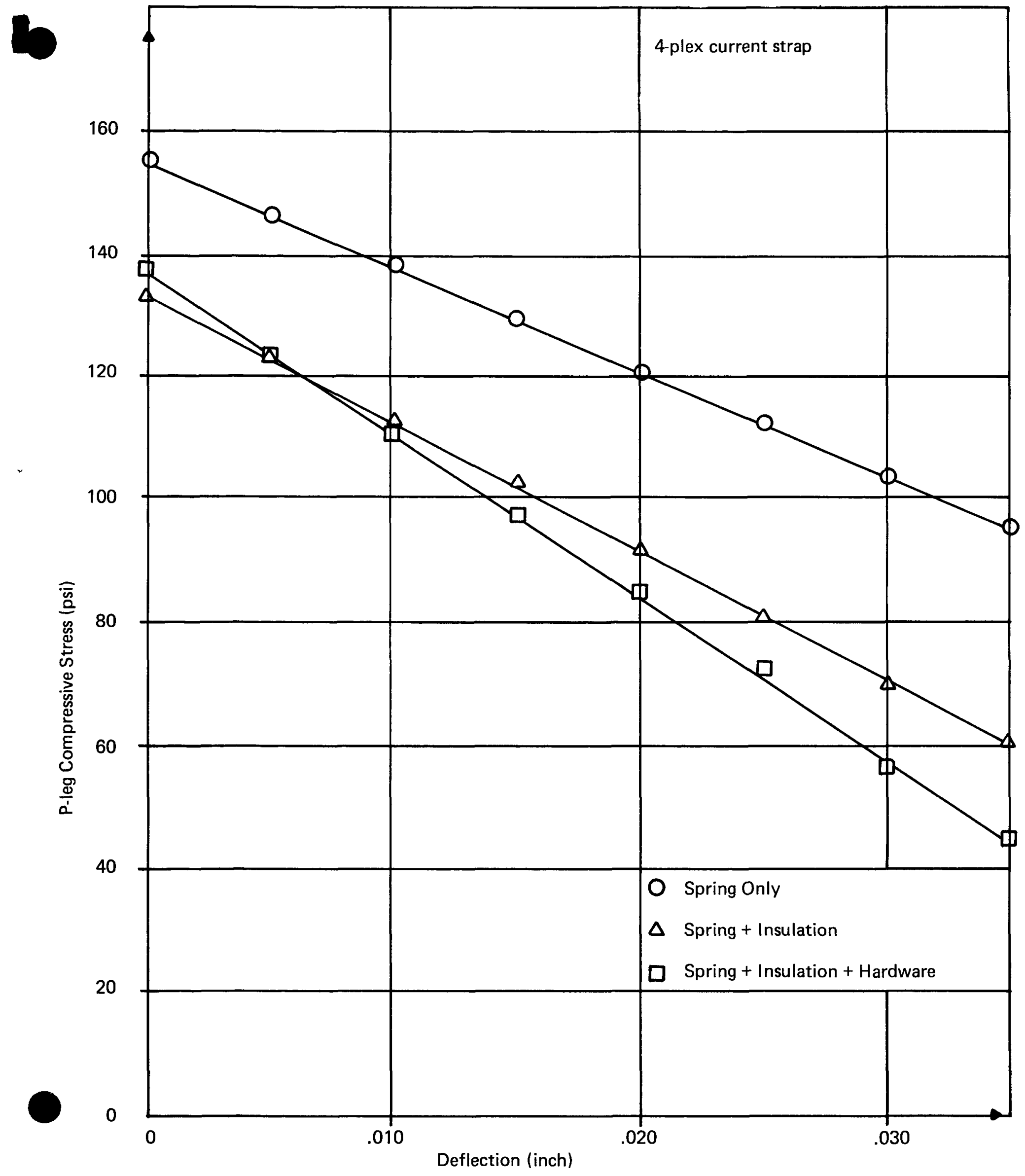

FIGURE 6-13 


\section{6-15}

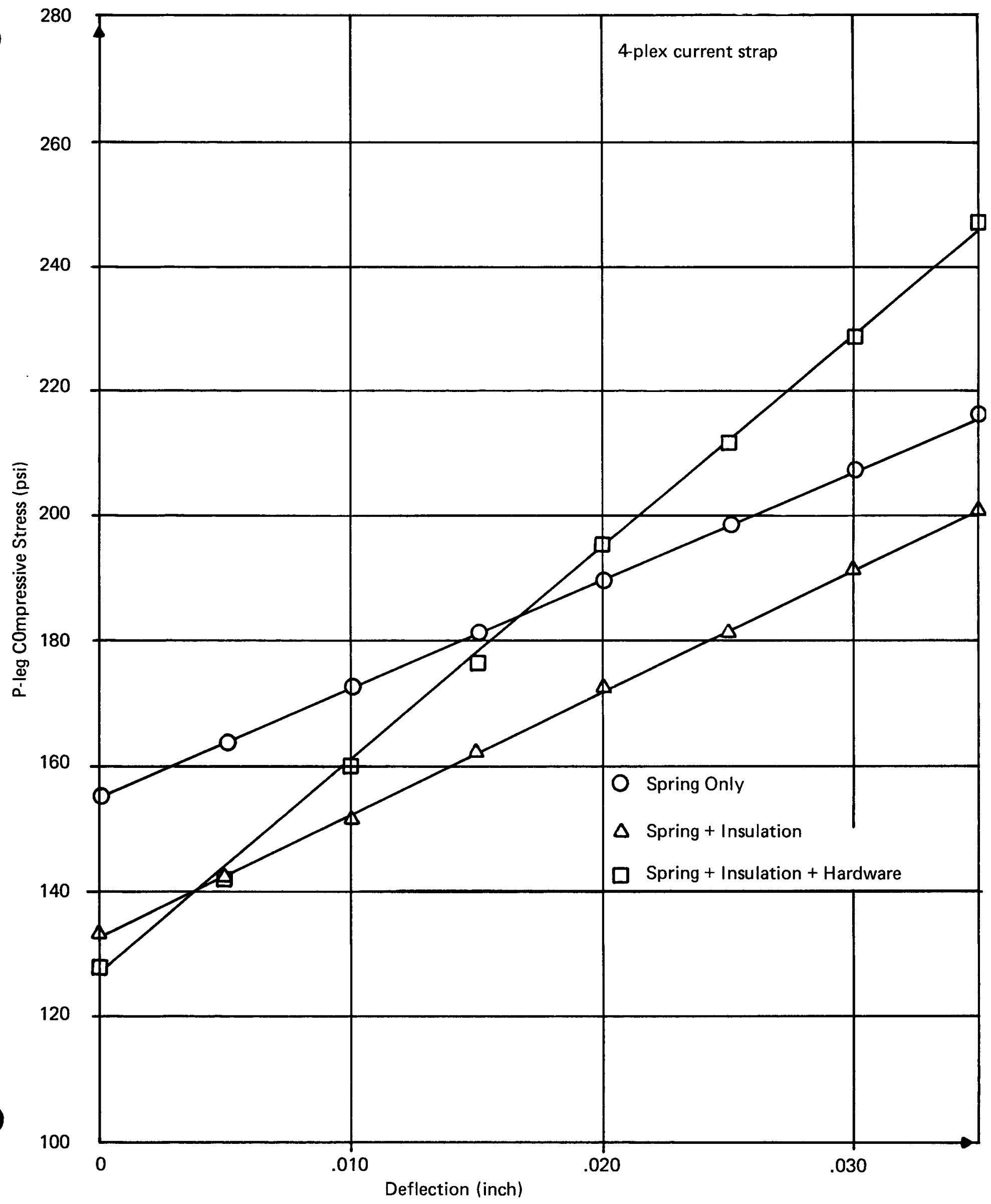

FIGURE 6-14: P-LEG COMPRESSIVE STRESS 'VS' DEFLECTION 


\section{ATTACHMENT 7 \\ Load Relaxation in Springs}

\section{Description}

$\mathrm{N}$ and P-leg springs in $\mathrm{M7}$ experienced severe load relaxation problems. Post test analyses showed that at operating spring height, $P$-leg compressive loads ran between 1 and 4 pounds, less than $50 \%$ of specification. Spring designs have been changed since then, and the latest design should do much to eliminate this problem.

The old springs were made from AISI A401 tempered Chrome-Silicon spring wire. The wire was coiled, ground and then stress relieved at $650-700^{\circ} \mathrm{F}$ for 45 minutes.

The new springs are being made from 17-7 PH 900C stainless steel, a material specially developed for high temperature use and having load relaxation characteristics superior to AISI A401. The fabricating procedure is also different. The wire is coiled for a free length longer than the design specification. The springs are then set (compressed to solid height) at room temperature in order to induce some inelastic deformation in the spring. This process will decrease the rate at which the load relaxes. Following the set, the springs are heat treated at $900^{\circ} \mathrm{F}$ to increase the hardness of the material, and afterwards are ground to the specified free length.

There are two (2) questions that need to be answered in order to evaluate the security of the current design:

1) Is the relaxation problem directly related to design?

2) Is it related to the operating environment?

The design stress levels in the springs are moderately high, ranging between $70 \mathrm{ksi}$ for the P-leg spring, and $100 \mathrm{ksi}$ for the $\mathrm{N}$-leg spring (although the stress levels may have been as high as 130 $\mathrm{ksi}$ in the M-7 springs for some conditions). These nominal stress levels are reasonable. Also, for an operating temperature of $150^{\circ} \mathrm{C}, \mathrm{A} 401 \mathrm{Chrome}-S i l i c o n$ steel should be adequate. However, literature that has been found indicates that 17-7 $\mathrm{PH}$ should be a superior material. Additional spring material will be evulated as this effort continues under the ongoing Technology Program.

It is quite likely that the excessive load relaxation encountered in module $M 7$ is attributable to the absence of a set procedure. It is generally accepted by the spring industry that a set spring will relax at a much lower rate than an unset spring. Some springs are set at elevated temperature. It is not clear whether a high temperature set provides additional protection against relaxation, but some quick tests performed for us by Lee Spring indicate that it might. Other than this slight modification, there are no others that we know of that might provide us with a better spring.

It is possible that the springs could be reacting with vapors present in the environment. Possible contaminants include Se and $O$. 
2. Efforts which will continue under the Technology Program

1) M7 springs are being analyzed to confirm that the material is indeed A401. They will also be analyzed for Se and $\mathrm{O}$ content, and in the event that either is found in significant concentrations, cross-sectional concentration profiles will be measured.

2) A test fixture for aging springs at operating temperature was fabricated. Tests are isothermal rather than ingradient. Free length and spring constant are monitored vs log time. Tests will be terminated after 200 hours. Figure 7-1 describes briefly the first six tests. These tests were run at $150^{\circ} \mathrm{C}$. A more complete description of this test effort is contained in the System Testing Section (Section III-A). 


\begin{tabular}{|c|c|c|c|c|c|c|c|c|c|}
\hline Run No. & Material & $\begin{array}{l}\text { Type of } \\
\text { Spring }\end{array}$ & $\begin{array}{l}\text { No. of } \\
\text { Springs }\end{array}$ & No Set & $\begin{array}{l}\text { Room Temp- } \\
\text { erature Set }\end{array}$ & $\begin{array}{l}\text { High Temp- } \\
\text { erature Set }\end{array}$ & $\begin{array}{l}\text { Air } \\
\text { Envi- } \\
\text { ron- } \\
\text { ment }\end{array}$ & $\begin{array}{l}\text { Vacuum* } \\
\text { Envi- } \\
\text { ron- } \\
\text { ment }\end{array}$ & $\begin{array}{l}\text { Se Vapor } \\
\text { Present }\end{array}$ \\
\hline 1 & A-401 & N-Leg & 6 & $\sqrt{ }$ & & & $\sqrt{ }$ & & \\
\hline 2 & $\begin{array}{l}302 \\
\text { Stainless }\end{array}$ & N-Leg & 6 & $\sqrt{ }$ & & & $\sqrt{ }$ & & \\
\hline 3 & $17.7 \mathrm{PH}$ & N-Leg & 6 & & $\checkmark$ & & $\checkmark$ & & \\
\hline 4 & $17-7 \mathrm{PH}$ & N-Leg & 6 & & & $\sqrt{ }$ & $\checkmark$ & & \\
\hline 5 & 17-7 PH & N-Leg & 6 & & $\checkmark$ & & & $\checkmark$ & $\checkmark$ \\
\hline 6 & A-401 & P-Leg & 6 & $\sqrt{ }$ & & & & $\sqrt{ }$ & $\sqrt{ }$ \\
\hline
\end{tabular}

* Any test performed in vacuum will be monitored only before and after the run. 


\section{ATTACHMENT 8}

Weight and Exposed Surface Area of Cold End Copper Hardware

The following is the weight and surface area of the copper cold end hardware in the $\mathrm{SN}-1$ generator.

\begin{tabular}{|c|c|c|c|}
\hline \multicolumn{4}{|c|}{ Weight of Copper in Generator } \\
\hline Component & Unit Wt. & $\begin{array}{l}\text { No./ } \\
\text { Segment } \\
\end{array}$ & $\begin{array}{c}\text { Segment } \\
\text { Wt. } \\
\end{array}$ \\
\hline N Spring retainer & $.566 \mathrm{gm}$ & 6 & 3.396 \\
\hline P Spring retainer & $.264 \mathrm{gm}$ & 6 & 1.584 \\
\hline N Current Strap & $1.129 \mathrm{gm}$ & 1 & 1.129 \\
\hline P Current strap & $.871 \mathrm{gm}$ & 1 & .871 \\
\hline 4-Plex strap & $.652 \mathrm{gm}$ & 2 & 1.304 \\
\hline Follower & $1.192 \mathrm{gm}$ & 6 & 7.152 \\
\hline \multirow{2}{*}{\multicolumn{4}{|c|}{$(15.436 \mathrm{gm}) \times(56$ segments $/$ generator $)=864.4 \mathrm{gms}$ of copper/generator }} \\
\hline & & & \\
\hline \multicolumn{4}{|c|}{ Exposed Surface Area $\left(\mathrm{in}^{2}\right)$} \\
\hline Component & Unit Area & $\begin{array}{l}\text { No./ } \\
\text { Segment }\end{array}$ & $\begin{array}{l}\text { Segment } \\
\text { Area } \\
\end{array}$ \\
\hline P Spring retainer & .00048 & 6 & .00288 \\
\hline N Spring retainer & .00155 & 6 & .0093 \\
\hline P 2-Plex Current Strap & 1.0898 & 1 & 1.4814 \\
\hline N 2-Plex Current Strap & 1.4814 & 1 & 1.0898 \\
\hline 4-Plex strap & .6420 & 2 & 1.284 \\
\hline \multirow[t]{2}{*}{ Follower } & .6998 & 6 & 4.1988 \\
\hline & & Total $=$ & $8.066 \mathrm{in}^{2} /$ segment \\
\hline
\end{tabular}

$\left(8.066 \mathrm{in}^{2}\right) \times(56$ segments/generator $)=451.7 \mathrm{in}^{2}$ exposed surface area of copper in generator 


\section{ATTACHMENT 9}

SN-1 Weight Analysis

\section{Objective:}

- To analyze the component weights of the $\mathrm{SN}-1$ thermoelectric rings.

- Use these weights to obtain a composite weight picture of the thermoelectric ring assembly.

Conclusions:

Based on the information shown in Table 9-1, it can be seen that the actual weight of the thermoelectric ring assemblies for $\mathrm{SN}-1$ will be $13.8 / 14.5$ lbs. The design target was $16.0 \mathrm{lbs}$.

\section{Weight Analysis:}

Two (2) methods were used to derive the weights of the components listed in Table 9-1. In all cases where SN-1 component parts were available, samples from bonded stock were randomly selected and weighed. Whenever bonded stock components were not available, weight calculations were performed based on the material and dimensional properties shown in the appropriate $\mathrm{SN}-1$ drawing. The method used for each component is noted in the table. 
TABLE 9-1

\section{SN-1 WEIGHT SUMMARY (LBS.)}

Part

Hot Frame

Foil, Hot Shoe

Ceramic Pin

Strap, Current, H.E.

Gimbal

Ni Foil Disk

P-Leg Assembly

$\mathrm{N}$-Leg Assembly

Cold Frame Assembly

P-Spring

N-Spring

P-Twist Lock

$\mathrm{N}$-Twist Lock

Tin Foil

HiFi Insulation

Multifoil Pins
Nom. Unit Wt.

$.8883^{*}$

$.0000357^{*}$

.000089

.0100

.00192

.000132

.00583

.0062

.06805

.0015

.0029

.00036

.00068

$.025^{*}$

$.006^{*}$

$.000045^{*}$

\begin{tabular}{cc} 
Quantity/Gen. & Nom. Total Wt/Gen. \\
\cline { 2 - 2 } 2 & 1.780 \\
112 & .004 \\
336 & .030 \\
168 & 1.680 \\
336 & .644 \\
336 & .044 \\
336 & 1.960 \\
336 & 2.090 \\
56 & 3.811 \\
336 & .504 \\
336 & .974 \\
336 & .122 \\
336 & .228 \\
2 & .050 \\
56 & .316 \\
13 & .0006 \\
& \\
Generator Total: & 14.238
\end{tabular}

Weight Tolerance

$1.560 / 1.850$

$.004 / .007$

$.028 / 1.031$

$1.613 / 1.747$

$.632 / .659$

$.044 / .045$

$1.940 / 1.990$

2.070/2.120

$3.783 / 3.822$

$.484 / .518$

$.967 / .988$

$.121 / .123$

$.227 / .229$

$.040 / .060$

$.302 / .330$

$.0005 / .0006$

$13.816 / 14.520$

*Based on calculations. 


\section{ATTACHMENT 10 \\ Initial Phases of Axial Stress on N and P Legs}

\section{Objectives:}

The purpose of this attachment is to analyze the various modes of axial stress on the thermoelectric legs in the $\mathrm{SN}-1$ generator. Analysis will cover:

1. Range of stress at initial room temperature:

a) in the overcompressed assembly stage

b) in the fully assembled stage

2. Range of stress at initial heat-up

\section{Conclusion:}

Table 10-3 summarizes the range of stress on the legs for the various modes mentioned. The values given for stresses after heat-up may now be used as initial starting conditions.

\section{Analysis of Static Stresses:}

The initial stress on the legs is a factor of spring force and insulation compliance.

\section{Spring Force:}

To determine the force applied to each leg by the spring, the following calculations were performed for each mode, using nominal, maximum, and minimum values.
a) Determine stack heights using the known values of the housing and POCO hot frame, the approximate conditions. (Shown in Table 10-1)
b) Add the individual components in the stack (shown in Table 10-2).
c) Subtract this value from the appropriate stack height value in Table 10-1 to obtain the compressed spring length.
d) Subtract this compressed length from the free length of the spring to obtain the amount of spring compression.
e) Multiply this compression by the appropriate spring rate to obtain the spring force.

\section{Insulation Compliance:}

The initial spring force is reduced by the insulation compaction. With the use of an Instron Machine, this reduction of force has been determined to be $1.25 \mathrm{lbs}$.

The net stress applied to the legs is then determined by:

Stress $=($ Spring Force - Insulation Compliance $) /$ Area of Leg

The following pages describe these calculations in detail. A summary of the room temperature and heat-up stresses are summarized in Table 10-3. 
SN-1 Stack Height Calculations

Three (3) stages of stack height will be encountered by the thermoelectric ring:

1. Overcompressed Stack Height:

This describes the condition of the ring immediately prior to insertion into the housing. The amount of overcompression is .030" radially.

2. Fully Assembled Stack Height:

This condition occurs after rings have been completely assembled and released in the housing. The stress applied by the ring will cause the housing to deflect .0025 inches radially. This deflection is taken into account in the stack height calculations.

3. Heat-Up Stack Height:

This condition occurs after SN-1 has been brought up to temperature and accounts for .020 radial expansion (thermal) of the POCO hot frame.

Table 10-1 lists the various stages of stack height along with the tolerance range associated with each respective stage. The tolerance ranges are based on component tolerances taken from the design drawings.

Below is a sample calculation of the nominal overcompressed stack height:

Housing I.D. $=10.159 \pm .008$ inches

POCO across flats $=8.117 \pm .08$ inches

Stack Height $=($ Housing I.D. - POCO O.D. (Across flat) $) / 2-$ radial overcompression

$=(10.159-8.117) / 2-.030$

$=.991$ inches 


\section{Initial Stress Calculations}

Nominal: $\quad \sigma_{i}=\frac{1}{A_{\text {nom }}} \quad\left[F_{\text {si nom }}-F_{i \text { nom }}\right]$

where $F_{\text {si nom }}=K_{\text {nom }}\left[L F L\right.$ nom $-L_{C}$ nom]

Maximum: $\quad \sigma_{i}=\frac{1}{A_{\min }}\left[F_{\text {si } \max }-F_{i}\right]$

where $F_{\text {si max }}=K_{\max }\left[L_{F L \min }-L_{C \text { min }}\right]$

Minimum: $\quad \sigma_{\mathrm{i}}=\frac{1}{\mathrm{~A}_{\max }}\left[\mathrm{F}_{\mathrm{si} \min }-\mathrm{F}_{\mathrm{i}}\right]$

where $F_{\text {si min }}=K_{\min }\left[L_{F L \text { max }}-L_{C \text { max }}\right]$

Variables

$\sigma_{\mathbf{i}}=$ Stress on leg

$A=$ Cross-sectional area of leg (from leg spec.'s)

$F_{\text {si }}=$ Initial spring force

$F_{i}=$ Insulation compliance force (initial $=1.25$ lbs)

$\mathrm{K}=$ Spring constant (calculated from spring specifications)

$L_{F L}=\quad$ Spring free length (from spring spec.'s)

$L_{C}=$ Spring compressed length (calculated from Tables 1 and 2) 
Examples of Stress Calculations for P-leg in Overcompressed Stage:

\section{Nominal}

from Tables 10-1 and 10-2

$$
\begin{aligned}
\mathrm{L}_{\mathrm{C}} & =\text { Stack Height }- \text { Component Height Total } \\
\mathrm{L}_{\mathrm{C}} & =.9910-.5775 \\
\mathrm{~L}_{\mathrm{C}} & =.4135 \text { inches } \\
\mathrm{F}_{\mathrm{si}} & =\mathrm{K}\left[\mathrm{L}_{\mathrm{FL}}-\mathrm{L}_{\mathrm{C}}\right] \\
\mathrm{F}_{\mathrm{si}} & =94.4[.545-.4135] \\
\mathrm{F}_{\mathrm{si}} & =12.41 \mathrm{lbs} . \\
\sigma_{\mathrm{i}} & =\frac{1}{\mathrm{~A}}\left[\mathrm{~F}_{\mathrm{si}}-\mathrm{F}_{\mathrm{i}}\right] \\
\sigma_{\mathrm{i}} & =\frac{1}{.0547}[12.41-1.25] \\
\sigma_{i} & =204 \mathrm{lbs} / \mathrm{in}^{2}
\end{aligned}
$$

$\underline{\text { Maximum }}$

$\mathrm{L}_{\mathrm{C} \min }=\quad$ Minimum stack height - maximum component height total

$L_{C \text { min }}=.9865-.5915$

$L_{C} \min =.3950$ inches

$F_{\text {si max }}=K_{\max }\left[L_{F L \text { min }}-L_{C \text { min }}\right]$

$=112.5[.535-.395]$

$=\quad 15.75 \mathrm{lbs}$.

$\sigma_{i \max }=\frac{1}{A_{\min }}\left[F_{\text {si max }}-F_{i}\right]$

$\sigma_{\mathrm{i} \max }=267 \mathrm{lbs} / \mathrm{in}^{2}$ 
Minimum

$$
\begin{aligned}
\mathrm{L}_{\mathrm{m} \max } & =\text { Maximum stack height }- \text { Minimum component height total } \\
& =.9955-.5645 \\
& =\mathrm{K}_{\min }\left[\mathrm{L}_{\mathrm{F} L \max }-\mathrm{L}_{\mathrm{C} \text { max }}\right] \\
\mathrm{F}_{\text {si min }} & =80[.555-.431] \\
& =9.92 \mathrm{lbs} . \\
& =\frac{1}{A_{\max }}\left[F_{\mathrm{si} \min }-F_{\mathrm{i}}\right] \\
\sigma_{\mathrm{i} \min } & =\frac{1}{.0551}[9.92-1.25] \\
\sigma_{\mathrm{i} \min } & =157.4 \mathrm{lbs} / \mathrm{in}^{2}
\end{aligned}
$$

The remainder of the initial stress calculations will not be shown. The results are summarized in Table $10-3$. 
TABLE 10-1

STACK HEIGHTS (INCHES)

Overcompressed Stack Heights

(.030 overcompression)

Fully Assembled Stack Heights (with .0025 housing deflection)

Heat-Up Stack Height

(with .020 POCO expansion)
Nominal

.9910

Maximum Minimum

.9955

.9865

1.0235

1.0280

1.0190

1.0035

1.0080

.9990 
TABLE 10-2

Summation of Components in Stack

$\underline{N \text {-Leg Stack Dimensions (inches) }}$

Component

Pt. Hot End Foil

Hot Strap and Gimbal

$\mathrm{Ni}$ Foil

$\mathrm{N}$-Leg Assembly

Cold End Strap Assembly

Twist Lock

Cold Frame Assembly

Tin Foil
Nominal

.0005

.100

.005

.305

.075

.039

.040

.001

Total:
Maximum

.0005

.101

.006

.308

.081

.041

.042

.001

.5805
Minimum

.0005

.099

.004

.302

.069

.037

.038

.001

.5505

P-Leg Stack Dimensions (inches)

\section{Component}

Pt. Hot End Foil

Hot Strap

P-Leg Assembly

Cold End Strap Assembly

Twist Lock

Cold Frame Segment

Tin Foil

\begin{tabular}{l} 
Nominal \\
\hline .0005 \\
.068 \\
.354 \\
.075 \\
.039 \\
.040 \\
.001 \\
\hline .5775
\end{tabular}

Maximum

.0005

.069

.357

.081

.041

.042

.001

.5915
Minimum

.0005

.068

.351

.069

.037

.038

.001

.5645 
TABLE $10-3$

Initial Leg Stress Summary (PSI)

\begin{tabular}{|c|c|c|c|c|c|}
\hline \multicolumn{3}{|c|}{ P-LEG } & \multicolumn{3}{|c|}{ N-LEG } \\
\hline Nominal & Minimum & Maximum & Nominal & Minimum & Maximum \\
\hline 204 & 157 & 267 & 384 & 284 & 515 \\
\hline 148 & 110 & 200 & 276 & 196 & 381 \\
\hline 182 & 139 & 241 & 341 & 250 & 464 \\
\hline
\end{tabular}


HOT END

(POCO)
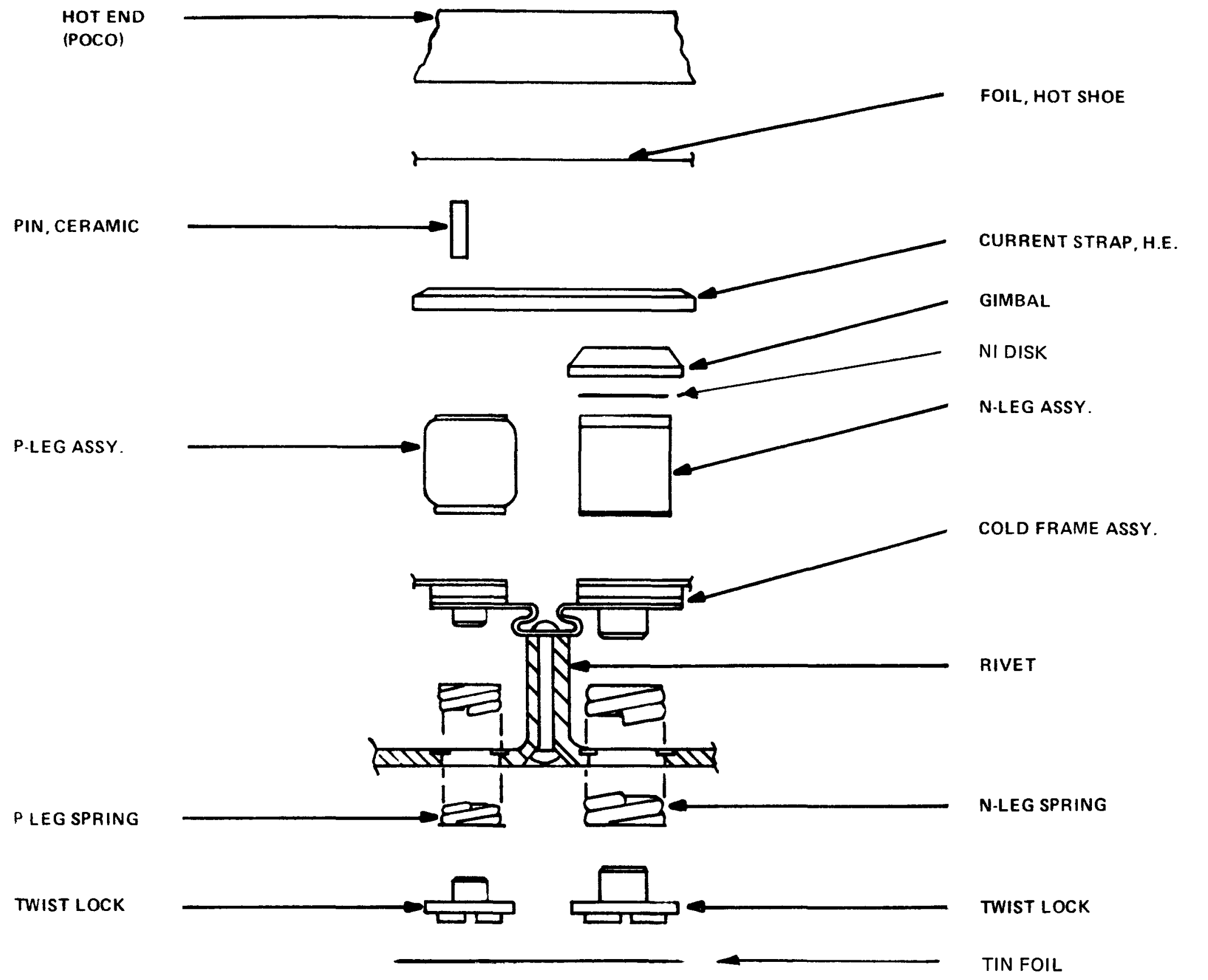

FIGURE 10-1: TYPICAL COUPLE HARDWARE 


\section{ATTACHMENT 11}

\section{Copper Stiffening During Diffusion Bonding}

During the early part of January, the T/E cold end diffusion bonding process was transferred to ARO Industries. During the initial installation of the glove box, a few alterations were introduced as follows:

1. A new pressure scale was altered to allow for operation in a high temperature environment.

2. The press was secured to the scale to prevent slipping during bonding.

3. The Pyrometer used to sense the heater temperature was calibrated.

4. A new heater block and firebrick retainer were installed.

5. New POCO pressure pads and retainers were fabricated to comply with the revised shape of the straps and followers.

After the installation was complete and the first followers were diffusion bonded, a drastic decrease in flexibility in the unbonded region was noted. A strong effort was immediately initiated to find the reason for this problem.

The new scale, secured press, and calibrated pyrometer seemed the least likely candidates for the problem.

The new POCO was analyzed by Central Research. Although some surface impurities were found (small amounts of sulpher and chlorine), the operating temperature of the POCO $\left(1020^{\circ} \mathrm{C}\right)$ will act as a natural processing step to eliminate them during bonding. No vanadium or other metallic contamination was detected.

Varying the operating temperature, pressure, and bonding time was attempted with little change in the excessive stiffness of the products.

The new design of the pressure pads and retainers was then investigated. It was found that by bonding the followers with no retainer produced a good flexible follower comparable to the old style that was bonded at $3 \mathrm{M}$. The new retainers were found to have a tighter fit to the followers. While bonding, the retainer is at or near the temperature of the heater block. With the tight fit between the edges of the follower, pressure pad, and retainer, a bond at the edges of the follower was being produced.

By recessing the inside surface of the retainer in the flexible region of the followers, the problem was eliminated. 
In an effort to further increase the flexibility and assure that bonding does not occur in the flex area, a new procedure as shown below was initiated.

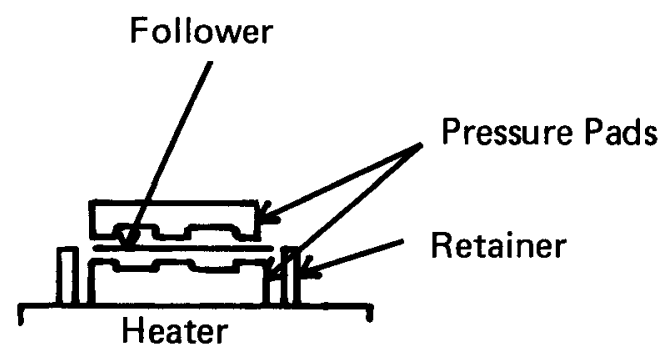

NEW

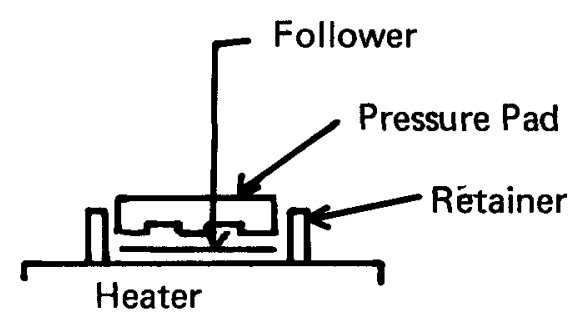

OLD

By inverting a thin pressure pad on top of the heater, the extreme, direct heat being applied to the bottom of the follower in the flexible regions is eliminated. This procedure will also be used for bonding the cold straps. 


\section{ATTACHMENT 12 \\ Reproduceability of Cold-End Hardware $\Delta T$}

\section{Introduction}

The sliding hardware has a high thermal resistance at the interface of the follower and rail. This resistance inhibited the flow of heat out of the element, and the proper temperature gradient was not obtainable. One of the reasons the compliant hardware was designed was to alleviate this problem. The heat pathway for the compliant hardware is illustrated on Figure 12-1. An important link in the pathway is the solder bond, and it can vary with each cold end assembly. The effect the quality of this bond has on the thermal resistance should be determined in order to insure the elements can obtain design operating conditions. This document will describe an effort that was made to determine the thermal resistance of six cold end assemblies, and the correlation to the bond qualities.

\section{Procedure}

The thermal resistance of the hardware was determined by exposing the follower assembly to a known heat flux, measuring the temperature difference between the base of the rail and follower, and then calculating the thermal resistance:

$$
\bar{R}=\frac{\left(\overline{T_{f}-\bar{T}_{r}}\right)}{\bar{Q}}
$$

when: $\bar{Q}=$ average heat flux through one leg

$$
\begin{aligned}
& T_{f}=\text { temperature of follower } \\
& T_{r}=\text { temperature at the base of rail } \\
& \bar{R}=\text { average thermal resistance of the thru rail pathway }
\end{aligned}
$$

X-rays were taken of the hardware, and inspected to differentiate between the quality of the bonds. The criteria used to decide on the grade of a bond was the melt of the solder. 


\section{$\underline{\text { Results }}$}

$\underline{\text { TABLE \#1 }}$

\begin{tabular}{|c|c|c|}
\hline Assembly \# & Thermal Resistance $\left({ }^{\circ} \mathrm{C} / \mathrm{W}\right)$ & Bond Quality \\
\hline 1 & 5.04 & Good \\
\hline 2 & 7.08 & Poor \\
\hline 3 & 7.92 & Fair \\
\hline 4 & 6.40 & Poor \\
\hline 5 & 6.42 & Good \\
\hline 6 & 6.22 & Poor \\
\hline
\end{tabular}

Note: Quality control specifications $7 \pm 3{ }^{\circ} \mathrm{C} / \mathrm{W}$

\section{Conclusion}

The thermal resistance of each specimen was compared to the $X$-ray, and it is concluded that there is no correlation between the thermal.resistance and the quality of the bond as indicated by the $X$-ray. The variation that did occur in the values can be explained by the different contact resistances experienced by the cold end assemblies in the test fixture. 


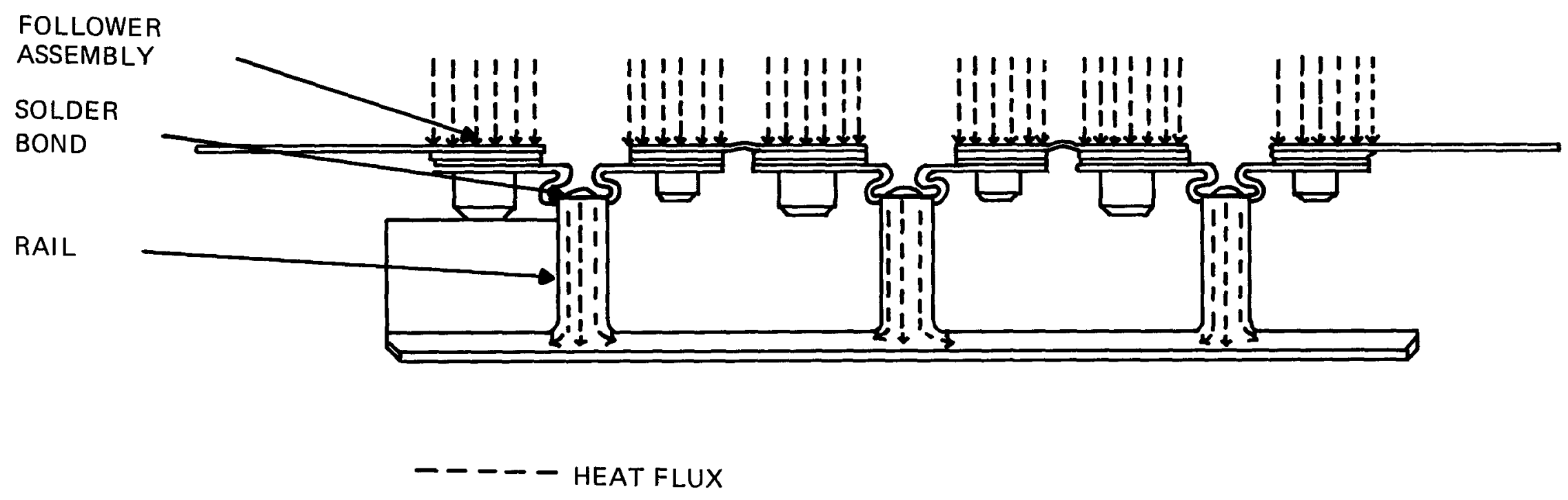

FIGURE 12-1: COLD END ASSEMBLY 


\section{DESIGN ANALYSIS}

\section{A. COUPLE PERFORMANCE PROGRAM}

\section{Description of the Program}

Through a cooperative effort between the Pioneering Lab and an independent support group within $3 \mathrm{M}$, a program for evaluating couple performance was developed. The approach used was to write an algorithm that solves the conservation of energy equation for the case of temperature dependent thermophysical properties. With the temperature profile and property profiles in hand it is a simple matter to compute the relevant performance indicators, e.g. heat flux input, power output and load voltage. The program was written to handle only onedimensional configurations (perfectly insulated), and currently accepts only specified temperature boundary conditions. Also both $\mathrm{N}$ - and P-leg models may be segmented. The program is sufficiently general as to allow it to be used not only for evaluation of existing designs, but also as a design tool. Property data for several state-of-the-art materials was incorporated in order to permit meaningful studies of relative potentials. The material library is listed in Figure II-1.

For the one-dimensional case, the equation describing the temperature distribution in a thermoelectric element is:

$$
-\frac{d}{d x}\left(k(T) \frac{d T}{d x}\right)+T \frac{d x(T)}{d x}-\rho(T) J^{2}=0
$$

where $k(T)$ is thermal conductivity, $\propto(T)$ is the Seebeck coefficient, $\rho(T)$ is the electrical resistivity, $\mathrm{J}$ is the current density, $T$ is temperature and $\mathrm{x}$ is the spatial coordinate. This equation, when integrated over a finite control volume, yields the finite difference equation:

$\dot{\mathrm{Q}}_{\mathrm{x}}+\mathrm{dx}=\dot{\mathrm{Q}}_{\mathrm{x}}+\dot{\mathrm{Q}}_{\mathrm{gx}}, \dot{\mathrm{Q}}_{\mathrm{gx}}=-1 \boldsymbol{T}_{\mathrm{x}}\left(\alpha_{\mathrm{x}}+\mathrm{dx}{ }^{-\propto} \mathrm{x}\right)+1^{2} \mathrm{R}_{\mathrm{x}}$

where $\dot{Q}$ represents heat flux, the subscript g means internally generated, $\bar{T}_{x}$ is a locally averaged temperature, 1 is the current flow, and $R_{X}$ is a local electrical resistance. Figures II-2 and II-3 illustrate how the difference equation is utilized. Note that this is a forward integration algorithm.

As Figure II-3 shows, it is necessary to iterate for property values simultaneously with temperature since the properties are temperature dependent. With the exception of P-leg carrier concentration, all property data is stored in subroutines. The carrier concentration is calculated within the program itself. The equation describing the distribution of extrinsic carriers is:

$\vec{\nabla} n_{0}=B \frac{1}{A}\left(\frac{T}{773}\right)^{2 / 3}$ 
The solution to this equation can be suitably approximated by:

$$
n_{0}(x+d x)=n_{0}(x)+B \frac{1}{A}\left(\frac{T(x)+T(x+d x)}{(2)(773)}\right)^{2 / 3} d x
$$

where $B$ is a constant of known value, $A$ is cross-sectional area, and $(x)$ means at location $x$. Note that $n_{o}$ at $x=0$ ties down the carrier concentration throughout the leg. (Recall that the carrier concentration at $x=0$ (the cold end of the P-leg) is tied down by bonding a copper disc onto the leg there.)

It is known that at very high temperatures, the excitation of intrinsic carriers becomes important. Since the equations describing P-leg property values in the program are expressed in terms of total carrier concentration $n_{+}$:

$$
n_{+}(x)=n_{0}(x)+g
$$

where

$$
g=a T^{4} \exp [-6605 / T] n_{+}-.92
$$

and a is a known constant. Notice that equation (5) requires an iterative solution. Figure II-4, essentially a modification of Figure II-3, illustrates how this computation fits into the algorithm.

Figure II-5 shows a flow chart for the entire program. It shows how the forward integration algorithm fits in.

\section{Accomplishments}

1. The algorithm's accuracy has been verified by comparison with an exact solution available in the literature 1 . The problem treated was sample 2 from the source cited. The problem was chosen because the thermoelectric properties are temperature dependent. The numerical solution appears in Figure $11-6$ and the exact solution is given in Figure 11-7. The problem was solved for maximum thermoelectric efficiency.

The excellent agreement between the two (2) solutions permits the following conclusion to be made: Discrepancies between experimental data and numerical data are attributable either to deviation from one-dimensional flow of heat and/or current, or to inaccuracy in property data equations.

1) Sherman et al, J. Appl. Phys., 31 - 1, Jan., 1960 
Material

1. $\mathrm{NdSe}_{\mathrm{x}}$

2. Orthorhombic $\mathrm{GdSe}_{\mathbf{x}}$

3. $2 \mathrm{~N} \mathrm{~Pb} / \mathrm{Te}$

4. $\operatorname{SiGe}(78 / 22) t=0$

5. Same as 4 $t=5 \mathrm{yrs}$.

6. TPM-217

7. $2 \mathrm{P} \mathrm{Pb} / \mathrm{Te}$

8. $\mathrm{SiGe}(78 / 22)$ $\mathrm{t}=\mathbf{0}$

9. Same as 8 $t=5$ years

10. Adv. SiGe (63/37)
Type

$\mathrm{N}$

$\mathrm{N}$

N

N

$N$

$\mathbf{P}$

$\mathbf{P}$

$\mathbf{P}$

$\mathbf{P}$

$\mathbf{P}$
Source

Largely from cubic $\mathrm{GdSe}_{X}$ data (should be similar); Partial confirmation on $\mathrm{S}$ and $\rho$ from single element tests $P / S 75$

(Ref. Top Summary Report 107, Table 4)

S and $\rho$ data from N2639 T3-14

$k$ data from N2646 T2-13

Internal memo by R.W. Fritts

Publication by V. Raag, 11 th IECEC

Same as 4

Extensive internal experimentation for $S$ and $\rho$. Comparative measurement at Resalab for $\mathrm{k}$ Pulse diffusivity at Battelle for $k$ Pulse diffusivity at Sandia for $k$

Same as No. 3

Same as No. 4

Same as No. 4

Publication by R.K. Pisharody and L.P. Garvey, 13th IECEC - Sample 2 


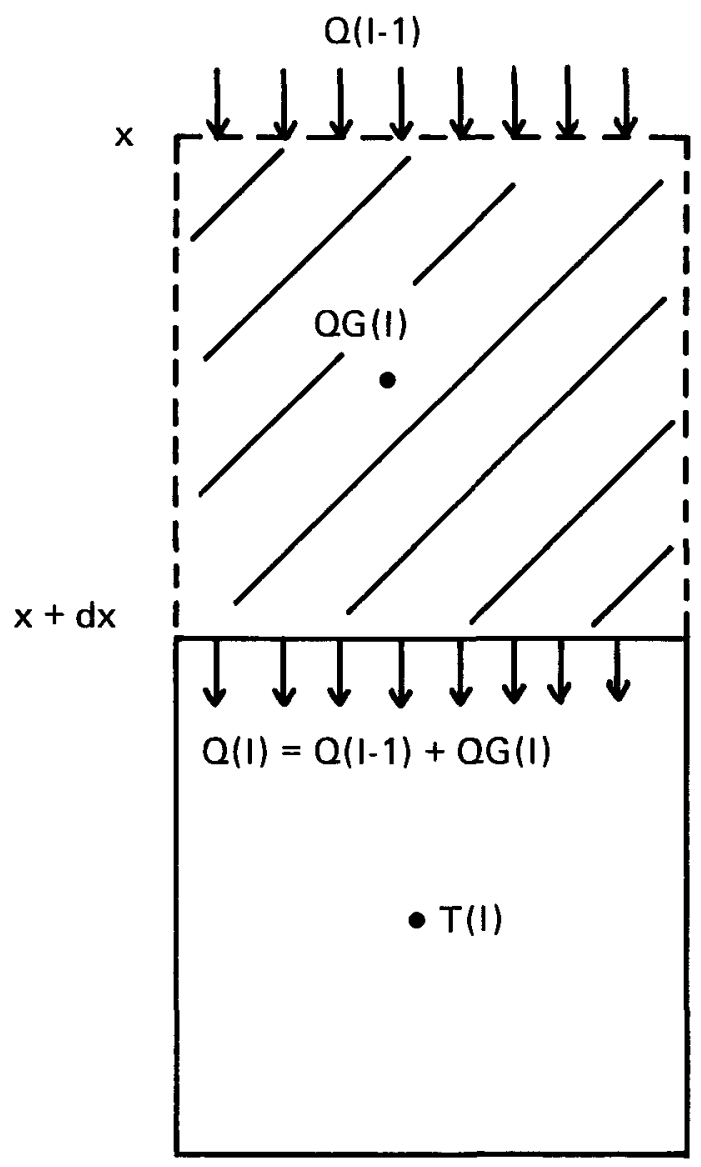

$(1-1)$

FIGURE II-2: GRAPHICAL REPRESENTATION OF THE COMPUTATION OF HEAT FLUXES 


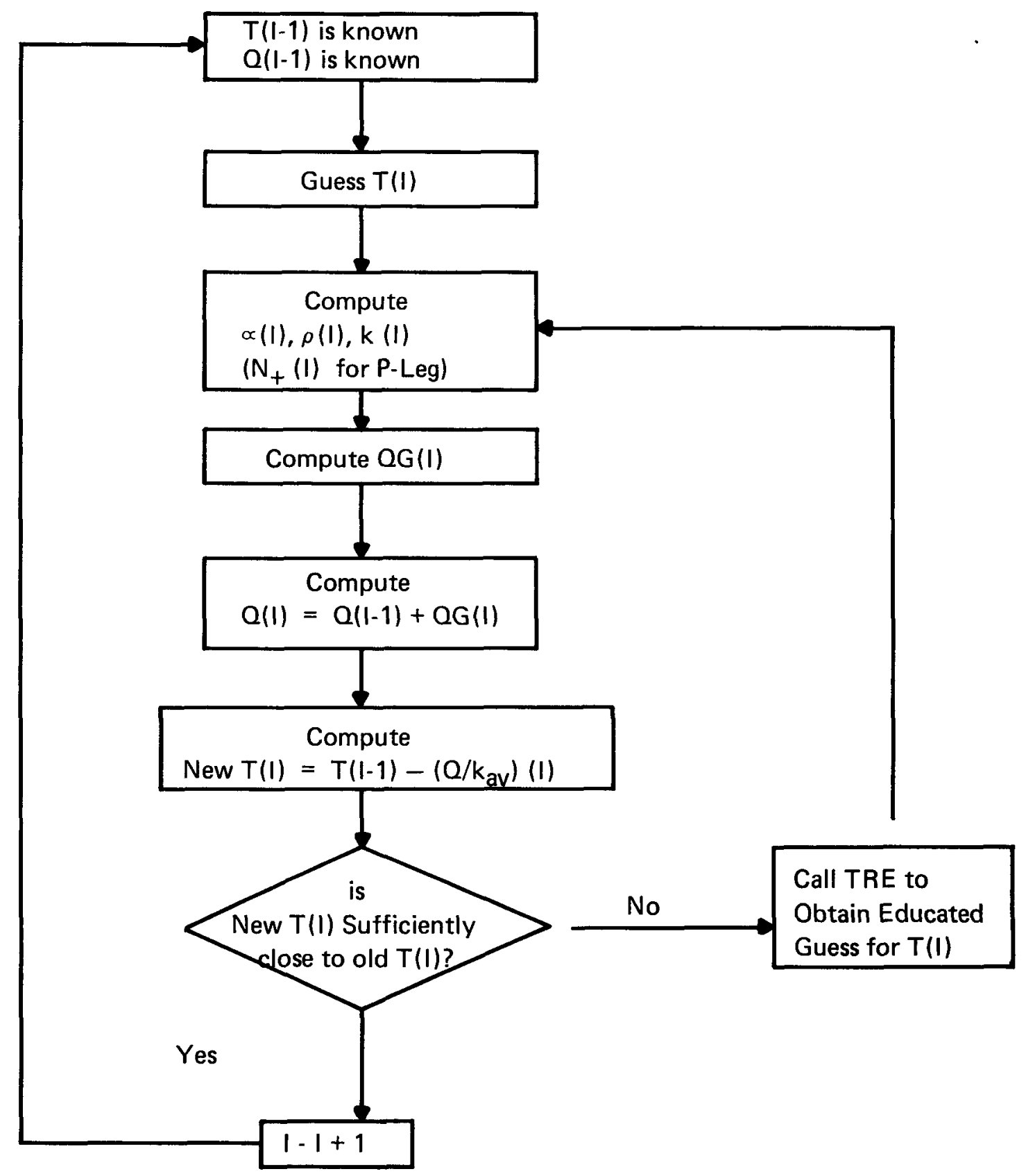

FIGURE II-3: FLOW CHART ILLUSTRATING FORWARD INTEGRATION PROCEDURE 


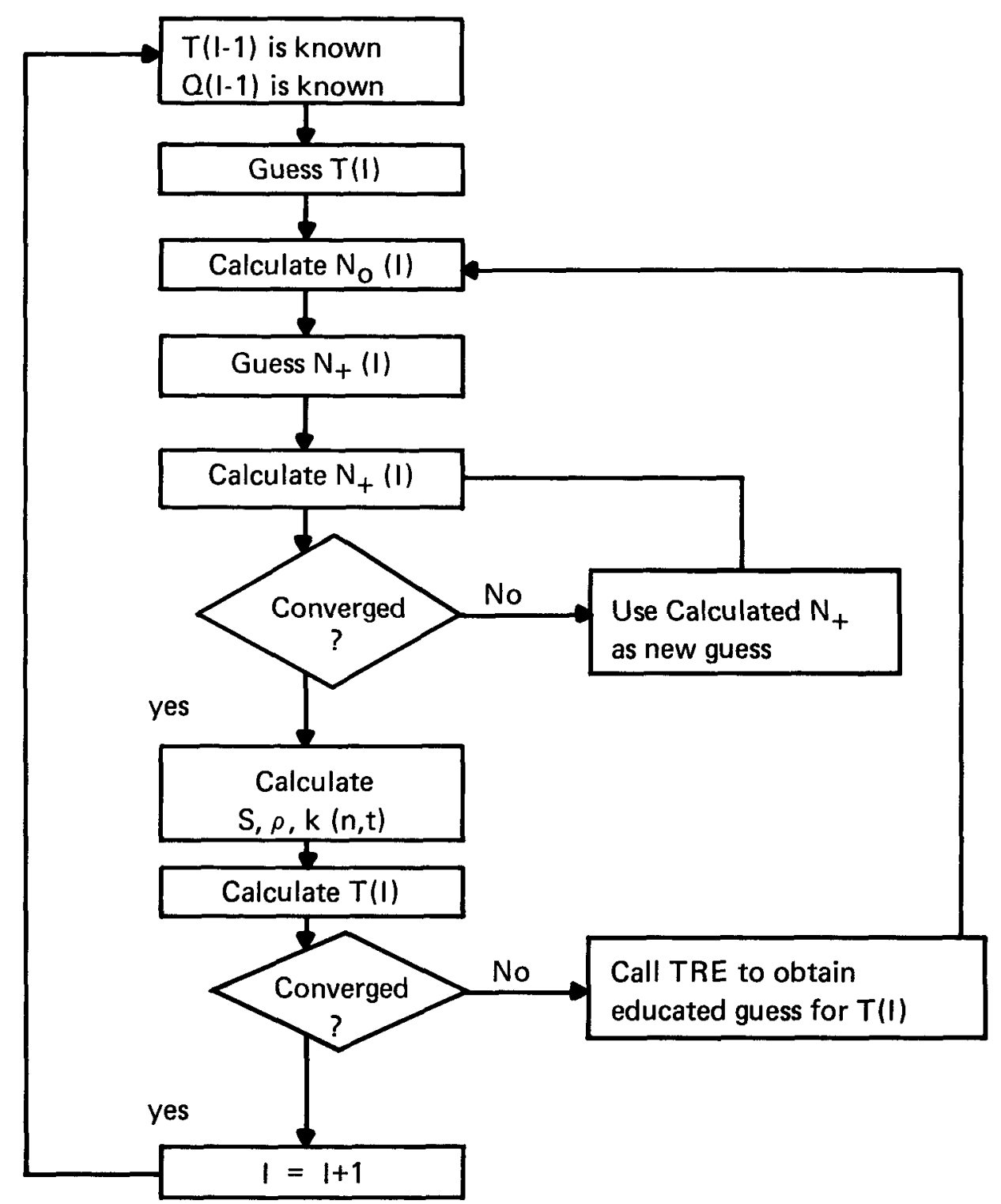

FIGURE II-4: FLOW CHART FOR P-LEG SOLUTION 
2. Seebeck coefficient and electrical resistivity models for the P-leg have been verified. Figure II-8 shows comparisons between the numerical model and several of the most recent tests conducted. For single element tests, seebeck coefficient predictions fall within $3 \%$ of measured values fairly consistently while electrical resistivity falls within $9 \%$.

3. A study was performed to determine a comparison of the selenides with respect to other state-of-the-art materials, e.g. Silicon Germanium and Lead Telluride systems. This was accomplished by calculating maximum attainable thermoelectric efficiency for various operating temperature intervals, with all thermal and electrical contact resistances set to 0 . The results, which are shown in Figure $11-9$, indicate a number of things. First, the selenide materials offer the potential for far superior performance over the Silicon Germanium systems. Second, the Silicon Germanium system has as a characteristic an unavoidable and predictable degradation mechanism that brings about a significant loss in efficiency over a five year period. Third, a lead telluride-selenide segmented $\mathrm{N}$-leg offers additional significant performance gains to the selenide systems. The curve titled M-9 BOL has been included to show what level of performance has been attainable to date. Ideally, M-9 performance should have fallen near the curve entitled NdSe $x / T P M-217$.

The presence of electrical contact resistances and high resistances in the $\mathrm{N}$-leg are responsible for holding the performance down.

Figures $11-10$ and $11-11$ focus entirely on the selenides. These curves represent maximum attainable efficiencies for the conditions cited. Several interesting points can be made from these plots. First, the variation of $T_{H N}$ has a stronger effect on performance for couples with $\mathrm{NdSe}_{x} \mathrm{~N}$-legs than for couples with $\mathrm{GdSe}_{\mathbf{X}} \mathrm{N}$-legs. Similarly, performance is more sensitive to the temperature interval of the P-leg than to the temperature interval of any of the $\mathrm{N}$-legs. This is an indication that the P-leg is the largest contributor in any selenide couple thought of to date. Also, it indicates that a $\mathrm{NdSe}_{\mathbf{x}} \mathrm{N}$-leg plays a larger role than a $\mathrm{GdSe}_{\mathbf{X}} \mathrm{N}$-leg. These curves represent what should be attainable levels of performance.

4. It has been used to generate the $\mathrm{SN}-1$ leg designs, which will be used in M-22R. It has also been used to generate designs for $\mathrm{NdSe}_{x} \mathrm{~N}$-legs.

5. A study was conducted to determine how sensitive overall performance is to variations of various controllable parameters, e.g. thermoelectric element dimensions, hardware and contact resistances and thermoelectric material properties. The purpose of the sensitivity study was to answer the question: How much variability can be accepted from couple to couple and still be within the limits of acceptable performance? The information for the study was obtained by making a series of computations which involved perturbing one parameter while holding the others fixed ${ }^{2}$ and observing the effects on relevant performance parameters, e.g. thermoelectric efficiency, P-leg $T_{H}, N$-leg $T_{\text {seg }}$ and leg resistance. For all calculations, heat flux per couple and the load voltage were constrained to fixed values in order to simulate a module environment.

2) Note: In actuality, these parameters are not completely independent of one another so that it is impossible to vary one parameter and fix the others. However, the degree of dependency is low. 
N-Leg Calculations

\section{P-Leg Calculations}

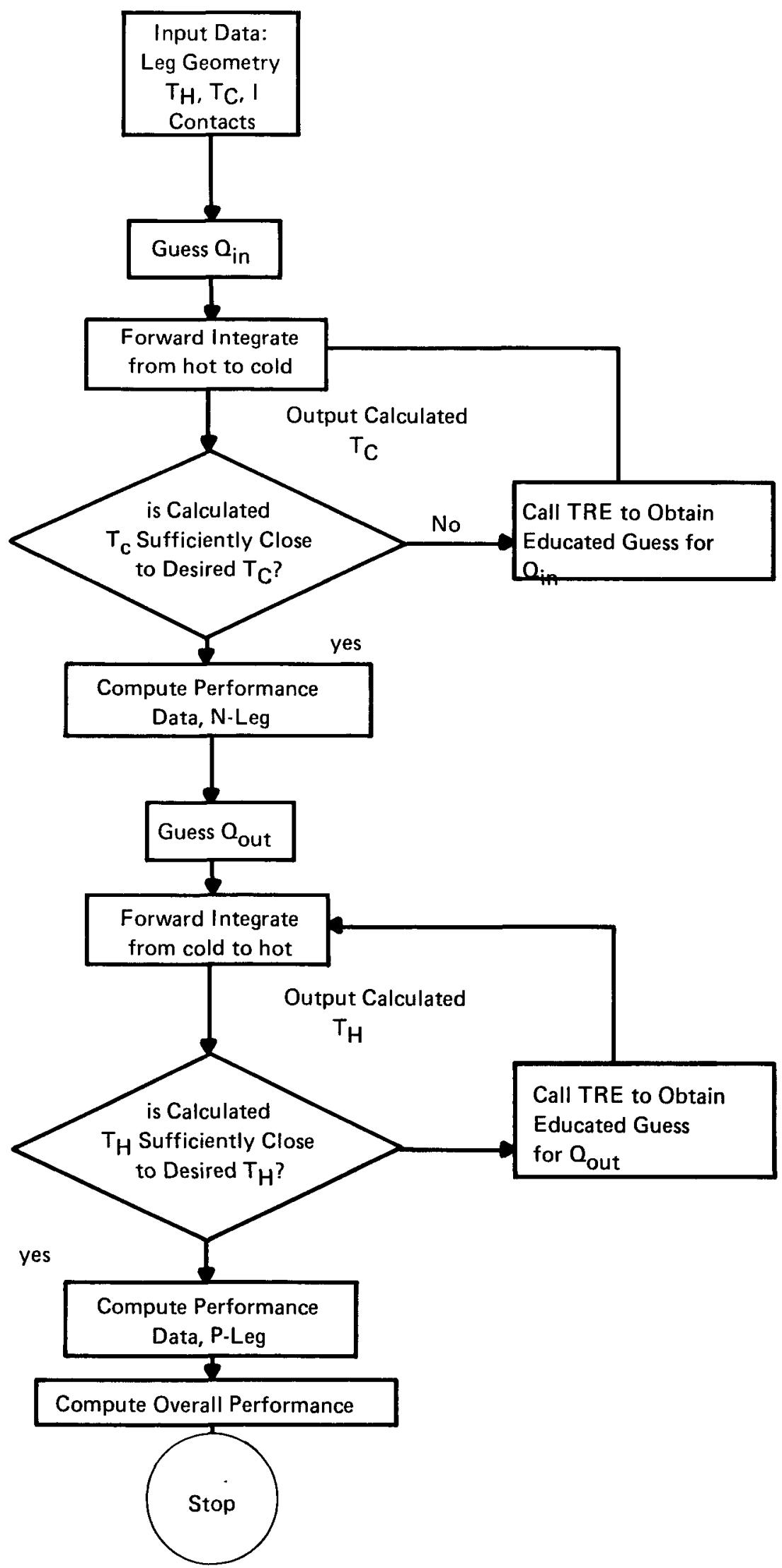

FIGURE II-5: A GENERAL FLOW CHART FOR PROGRAM COUPLE 1 
Couple 1, Exe. 7, 5-JUN-79

Enter Parameters: $0,1,1,5,1$

Increments: $.2, .1$

No. of N, P Leg Segments: 1, 1

$N$ Leg thermal contacts - hot to cold: 0,0

$N$ Leg Elec. contacts - hot to cold: 0, 0

$P$ Leg Thermal contacts - cold to hot: 0,0

$P$ Leg elec. contacts - cold to hot: 0,0

THN, THP, TON, TOP, I, ECC, Y: 1227, 1227, 127, 127, 55., 30., .0136

N Leg segments - N, D, L, Mat, Rext: 30, .942, .394, 4, 1.0

P Leg segments - N, D, L, Mat: 30, .444, .394, 2

$1, .100$

\%FRSAPR floating divide check $P C=6502$

\%FRSAPR floating overflow PC $=6507$

N-LEG SOLUTION

$\begin{array}{llllll}X & T(X) & K(X) & R H O(X) & \text { ALPH }(X) & \text { Q (X) } \\ .000 & \cdots & 2.00 & 15.00 & 100.0 & 22.78 \\ .035 & 2.12 & 14.17 & 116.6 & 22.27 \\ .069 & 2.24 & 13.42 & 131.7 & 21.37 \\ .104 & 999.6 & 2.36 & 12.73 & 145.5 & 20.62 \\ .138 & 936.1 & 2.48 & 12.09 & 158.2 & 19.99 \\ .173 & 877.4 & 2.61 & 11.50 & 169.9 & 19.46 \\ .207 & 822.8 & 2.74 & 10.96 & 180.8 & 19.01 \\ .242 & 771.8 & 2.87 & 10.45 & 191.0 & 18.63 \\ .276 & 723.9 & 3.01 & 9.97 & 200.6 & 18.30 \\ .311 & 679.0 & 3.15 & 9.52 & 209.6 & 18.03 \\ .345 & 636.6 & 3.30 & 9.10 & 218.1 & 17.79 \\ .380 & 596.6 & 3.45 & 8.70 & 226.1 & 17.59 \\ .414 & 558.7 & 3.61 & 8.32 & 233.7 & 17.42 \\ .449 & 522.7 & 3.77 & 7.96 & 240.9 & 17.27 \\ .483 & 488.6 & 3.94 & 7.62 & 247.7 & 17.15 \\ .518 & 456.1 & 4.11 & 7.29 & 254.2 & 17.05 \\ .552 & 425.1 & 4.30 & 6.98 & 260.4 & 16.96 \\ .587 & 395.6 & 4.49 & 6.69 & 266.3 & 16.89 \\ .621 & 367.4 & 4.68 & 6.40 & 271.9 & 16.83 \\ .656 & 340.4 & 4.89 & 6.13 & 277.3 & 16.79 \\ .690 & 314.7 & 5.10 & 5.88 & 282.5 & 16.75 \\ .725 & 290.1 & 5.33 & 5.63 & 287.4 & 16.73 \\ .759 & 266.5 & 5.56 & 5.40 & 292.1 & 16.71 \\ .794 & 244.0 & 5.80 & 5.17 & 296.6 & 16.69 \\ .828 & 222.4 & 6.06 & 4.95 & 300.9 & 16.69 \\ .863 & 201.7 & 6.32 & 4.75 & 305.1 & 16.69\end{array}$

FIGURE II-6: SAMPLE PROBLEM 2 SOLUTION 
N-LEG SOLUTION (Continued)

\begin{tabular}{|c|c|c|c|c|c|c|}
\hline$x$ & $T(X)$ & $K(X)$ & $\mathrm{RHO}(\mathrm{X})$ & ALPH $(X)$ & $Q(X)$ & \\
\hline .897 & 181.8 & 6.60 & 4.55 & 309.0 & 16.69 & \\
\hline .932 & 162.8 & 6.88 & 4.36 & 312.8 & 16.70 & \\
\hline .966 & 144.5 & 7.18 & 4.18 & 316.5 & 16.71 & \\
\hline$\leftrightarrow \leftrightarrow$ & 127.1 & 7.50 & 4.00 & 320.0 & 16.72 & \\
\hline$\bullet \bullet \bullet \bullet$ & 535.0 & 4.27 & 8.08 & 238.4 & 22.78 & $\begin{array}{l}\text { Integrated } \\
\text { Averages }\end{array}$ \\
\hline SEG. NO & THOT & TCOLD & & & & \\
\hline 1 & 1227.0 & 127.1 & & & & \\
\hline \multicolumn{7}{|c|}{ POUT $=7.2500$} \\
\hline \multicolumn{7}{|c|}{$\mathrm{Q} I N=30.969$} \\
\hline \multicolumn{7}{|c|}{ RES $=1.80$} \\
\hline$E F F=.23$ & & & & & & \\
\hline
\end{tabular}

P-LEG SOLUTION

\begin{tabular}{|c|c|c|c|c|c|c|}
\hline$x$ & $T(X)$ & $E N(X)$ & $K(X)$ & $\mathrm{RHO}(\mathrm{X})$ & ALPH $(X)$ & $Q(X)$ \\
\hline .000 & 127.0 & .099 & 25.00 & 2.50 & 200.0 & $\leftrightarrow \leftrightarrow \leftrightarrow \bullet \bullet$ \\
\hline .035 & 149.0 & .111 & 23.70 & 2.37 & 200.0 & $\bullet \leftrightarrow \bullet \bullet \bullet$ \\
\hline .069 & 171.9 & .123 & 22.48 & 2.25 & 200.0 & $\leftrightarrow \leftrightarrow \bullet \bullet$ \\
\hline .104 & 195.6 & .136 & 21.34 & 2.13 & 200.0 & $\leftrightarrow \leftrightarrow \bullet \bullet$ \\
\hline .138 & 220.2 & .149 & 20.28 & 2.03 & 200.0 & $\leftrightarrow \leftrightarrow \bullet \bullet$ \\
\hline .173 & 245.7 & .162 & 19.28 & 1.93 & 200.0 & $\bullet \leftrightarrow \bullet \bullet$ \\
\hline .207 & 272.1 & .176 & 18.34 & 1.83 & 200.0 & $\bullet \leftrightarrow \bullet \bullet \bullet$ \\
\hline .242 & 299.6 & .191 & 17.47 & 1.75 & 200.0 & $\bullet \bullet \bullet \bullet \bullet$ \\
\hline .276 & 328.0 & .206 & 16.64 & 1.66 & 200.0 & $\leftrightarrow \leftrightarrow \bullet \bullet$ \\
\hline .311 & 357.5 & .221 & 15.86 & 1.59 & 200.0 & $\leftrightarrow \leftrightarrow \bullet \bullet$ \\
\hline .345 & 388.0 & .237 & 15.13 & 1.51 & 200.0 & $\bullet \leftrightarrow \bullet \bullet \bullet$ \\
\hline .380 & 419.7 & .253 & 14.44 & 1.44 & 200.0 & $\leftrightarrow \leftrightarrow \bullet$ \\
\hline .414 & 452.5 & .270 & 13.78 & 1.38 & 200.0 & $\bullet \leftrightarrow \bullet \bullet \bullet$ \\
\hline .449 & 486.5 & .288 & 13.17 & 1.32 & 200.0 & $\leftrightarrow \leftrightarrow \leftrightarrow \bullet$ \\
\hline .483 & 521.7 & .306 & 12.58 & 1.26 & 200.0 & $\leftrightarrow \leftrightarrow \bullet \bullet \bullet$ \\
\hline .518 & 558.1 & .324 & 12.03 & 1.20 & 200.0 & $\leftrightarrow \leftrightarrow \bullet \bullet$ \\
\hline .552 & 595.9 & .343 & 11.51 & 1.15 & 200.0 & $\leftrightarrow \leftrightarrow \bullet \bullet$ \\
\hline .587 & 635.0 & .363 & 11.01 & 1.10 & 200.0 & 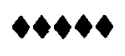 \\
\hline .621 & 675.5 & .384 & 10.54 & 1.05 & 200.0 & $\leftrightarrow \leftrightarrow \leftrightarrow \bullet$ \\
\hline .656 & 717.4 & .405 & 10.10 & 1.01 & 200.0 & $\leftrightarrow \leftrightarrow \leftrightarrow \bullet$ \\
\hline .690 & 760.8 & .427 & 9.67 & 0.97 & 200.0 & $\leftrightarrow \leftrightarrow \bullet \bullet$ \\
\hline
\end{tabular}

FIGURE II-6: SAMPLE PROBLEM 2 SOLUTION (Continued) 
P-LEG SOLUTION (Continued)

\begin{tabular}{|c|c|c|c|c|c|c|}
\hline$x$ & $T(X)$ & $E N(X)$ & $K(X)$ & RHO (X) & $\operatorname{ALPH}(X)$ & $a(x)$ \\
\hline .725 & 805.8 & .450 & 9.27 & 0.93 & 200.0 & $\leftrightarrow \bullet \bullet$ \\
\hline .759 & 852.3 & .473 & 8.89 & 0.89 & 200.0 & $\leftrightarrow \leftrightarrow \bullet \bullet$ \\
\hline .794 & 900.5 & .498 & 8.52 & 0.85 & 200.0 & $\leftrightarrow \bullet \bullet \bullet$ \\
\hline .828 & 950.3 & .524 & 8.17 & 0.82 & 200.0 & $\leftrightarrow \leftrightarrow \bullet \bullet$ \\
\hline .863 & $\leftrightarrow \bullet \bullet \bullet$ & .551 & 7.84 & 0.78 & 200.0 & \\
\hline .897 & $\leftrightarrow \leftrightarrow \bullet \bullet$ & .580 & 7.53 & 0.75 & 200.0 & \\
\hline .932 & $\leftrightarrow \leftrightarrow \leftrightarrow \bullet$ & .610 & 7.23 & 0.72 & 200.0 & \\
\hline .966 & $\leftrightarrow \leftrightarrow \bullet \bullet$ & .643 & 6.94 & 0.69 & 200.0 & \\
\hline \multicolumn{7}{|l|}{$\leftrightarrow \leftrightarrow \bullet$} \\
\hline$\bullet \bullet \bullet$ & 585.2 & .338 & 13.43 & 1.34 & 200.0 & \\
\hline
\end{tabular}

$\begin{array}{cll}\text { SEG. NO } & \text { THOT } & \text { TCOLD } \\ 1 & 1227.0 & 127.0\end{array}$

POUT $=7.9994$

$\mathrm{Q} I \mathrm{~N}=28.032$

RES $=1.35$

$E N C=.0991$

$\mathrm{ENH}=.6784$

$E F F=.28537$

POUT $=\bullet \bullet \bullet \bullet \bullet \bullet \bullet$

QTOT $=59.001$

T.E. EFF $=.25846 \longrightarrow \eta=25.8 \%$

$\mathrm{ECC}=46.92128 \longrightarrow$ Ecc per Couple $=\frac{46.92}{168}=.279 \mathrm{~V} \longrightarrow$ Load Resistance $=\frac{.279 \mathrm{~V}}{54.6 \mathrm{~A}}=5.12 \mathrm{mr}$

AMPS $=54.60000 \longrightarrow I=54.6$ Amps

FIGURE II-6: SAMPLE PROBLEM 2 SOLUTION (Continued) 
Maximum Thermoelectric Efficiency $=26 \%$

Load Resistance $=51 \mathrm{~m} \Omega$

Current Flow $=55 \mathrm{~A}$

FIGURE II-7: THE EXACT SOLUTION CORRESPONDING TO THE APPROXIMATE SOLUTION OF FIGURE 5 
A. Single Element Tests

\begin{tabular}{|c|c|c|c|c|c|c|}
\hline \multirow{2}{*}{$\begin{array}{l}\text { Test } \\
\text { Name }\end{array}$} & \multirow{2}{*}{$\begin{array}{l}\text { Temperature } \\
\text { Interval }\left({ }^{\circ} \mathrm{C}\right)\end{array}$} & \multirow{2}{*}{$\begin{array}{l}\text { IL/A } \\
(\mathrm{A} / \mathrm{cm})\end{array}$} & \multicolumn{2}{|c|}{ Seebeck Coef $\left(\mu \mathrm{V} /{ }^{\circ} \mathrm{C}\right)$} & \multicolumn{2}{|c|}{ Resistivity $(\mathrm{m} \Omega-\mathrm{cm})$} \\
\hline & & & Measured & Predicted & Measured & Predicted \\
\hline ATT 591 & $900 / 150$ & 10.8 & -- & 241 & -- & 6.67 \\
\hline ATT 592 & $900 / 150$ & 10.8 & 220 & 241 & 6.10 & 6.67 \\
\hline ATT 593 & $900 / 150$ & 10.8 & 220 & 241 & 6.10 & 6.67 \\
\hline ATT 594 & $900 / 150$ & 10.8 & 233 & 241 & 6.40 & 6.67 \\
\hline ATT 595 & $900 / 150$ & 10.8 & 241 & 241 & 7.00 & 6.67 \\
\hline ATT 596 & $900 / 150$ & 10.8 & 234 & 241 & 7.10 & 6.67 \\
\hline $\mathrm{CC} 1$ & $800 / 200$ & 0.60 & 288 & 283 & 16.6 & 14.2 \\
\hline$"$ & $800 / 200$ & 4.71 & 277 & 270 & 12.0 & 10.6 \\
\hline$"$ & $800 / 200$ & 9.42 & 260 & 258 & 9.27 & 8.46 \\
\hline$"$ & $800 / 200$ & 14.61 & 247 & 246 & 7.56 & 7.06 \\
\hline$"$ & $800 / 200$ & 18.85 & 240 & 239 & 6.66 & 6.27 \\
\hline ATT 600 & $900 / 164$ & 16.51 & 235 & 239 & 5.71 & 6.19 \\
\hline
\end{tabular}

\begin{tabular}{|lll|l|c|c|c|}
\hline \multirow{2}{*}{$\begin{array}{l}\text { Test } \\
\text { Name }\end{array}$} & Temperature & IL/A & \multicolumn{2}{|c|}{ Seebeck Coef $\left(\mu \mathrm{V} /{ }^{\circ} \mathrm{C}\right)$} & \multicolumn{2}{|c|}{ Resistivity $(\mathrm{m} \Omega$-cm $)$} \\
\cline { 6 - 8 } & Interval $\left({ }^{\circ} \mathrm{C}\right)$ & $(\mathrm{A} / \mathrm{cm})$ & Measured & Predicted & Measured & Predicted \\
\hline M-21 & $913 / 160$ & 13.4 & 211 & 245 & 6.76 & 6.91 \\
ATT 590 & $850 / 150$ & 6.94 & 218 & 243 & 7.61 & 7.23
\end{tabular}

FIGURE I1-8: A COMPARISON OF THE P-LEG NUMERICAL MODEL WITH EXPERIMENT 


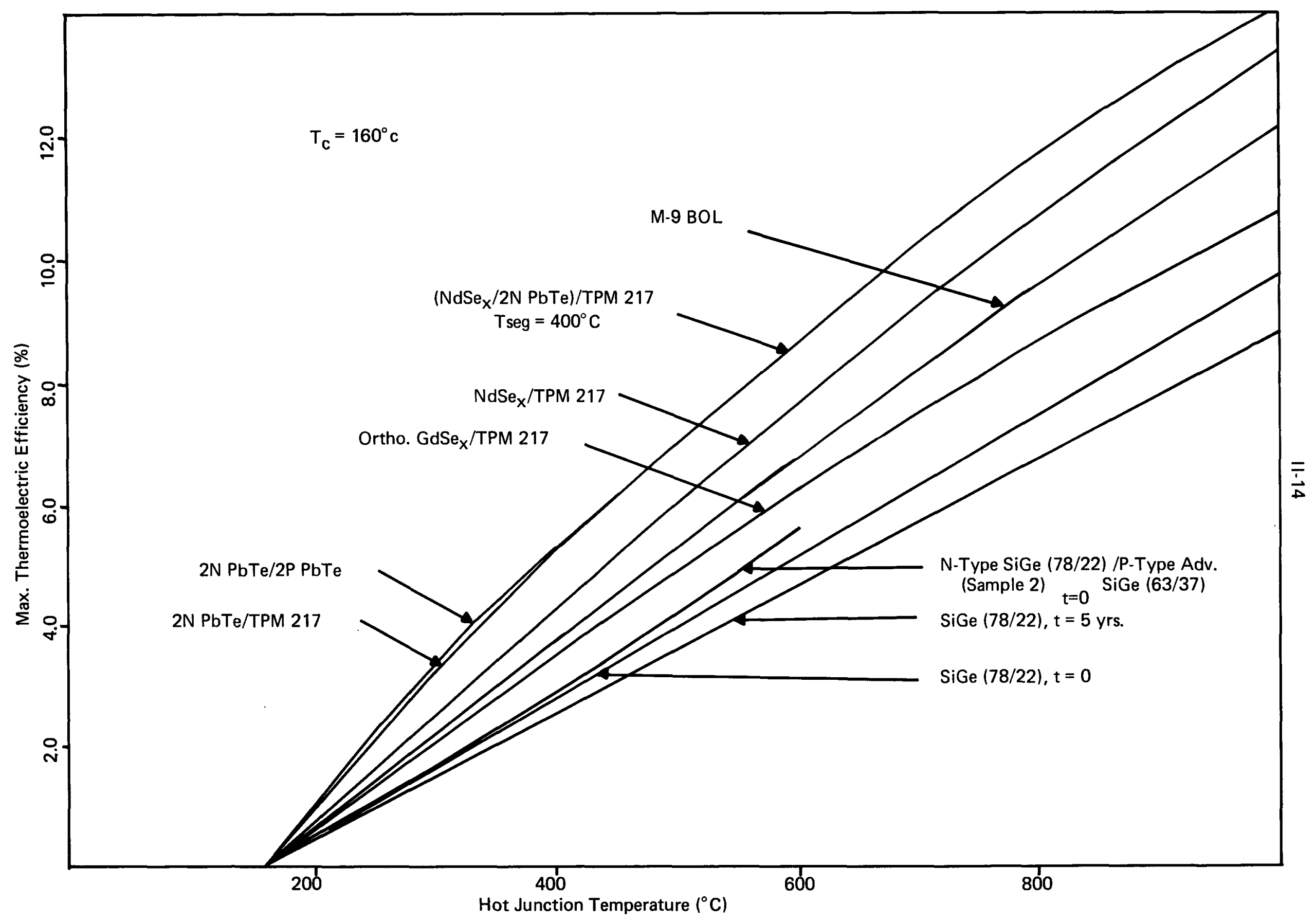

FIGURE II-9: A COMPARISON OF POTENTIALS FOR VARIOUS THERMOELECTRIC MATERIAL PAIRS 


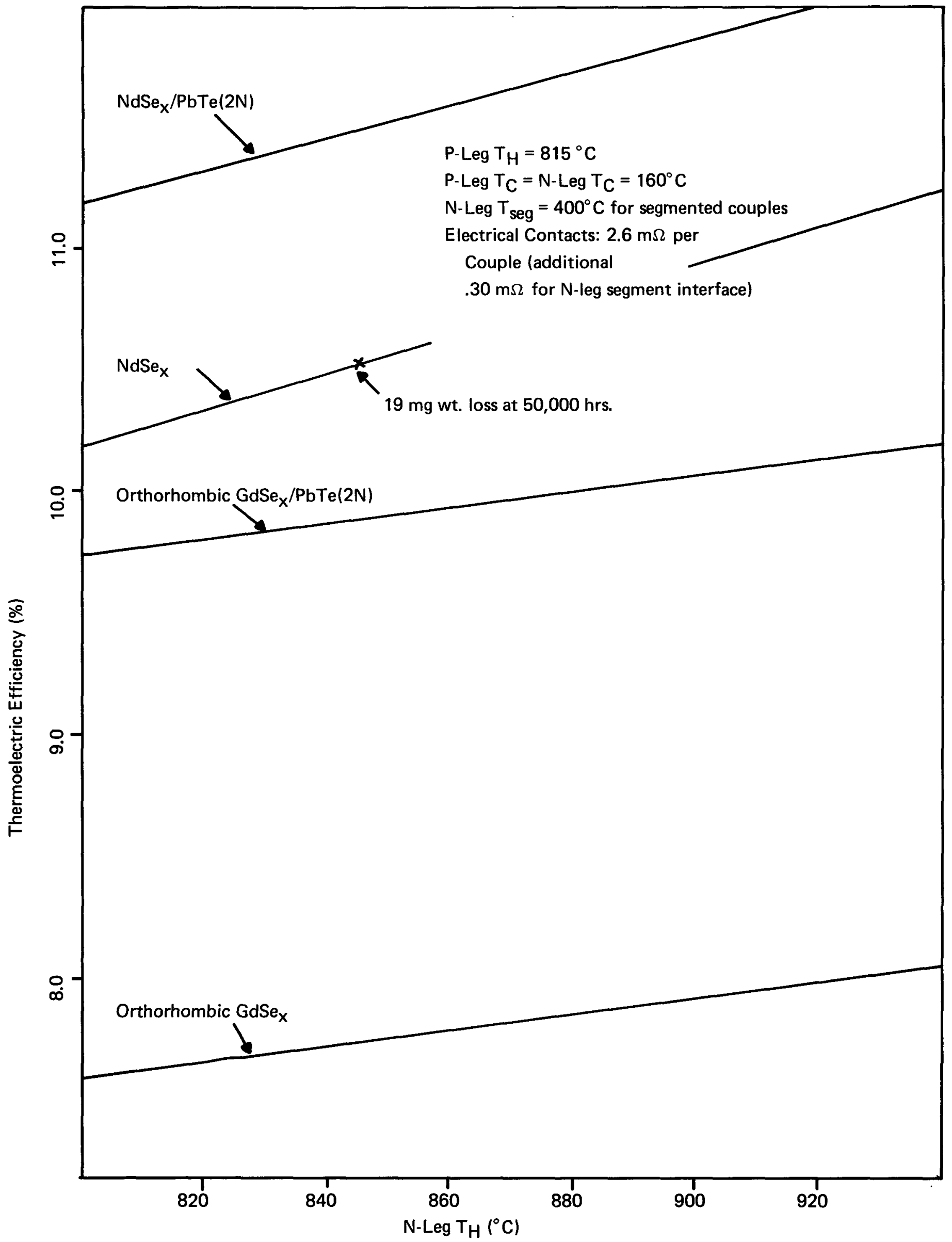

FIGURE II-10: THERMOELECTRIC EFFICIENCY VS. N-LEG HOT JUNCTION TEMPERATURE 


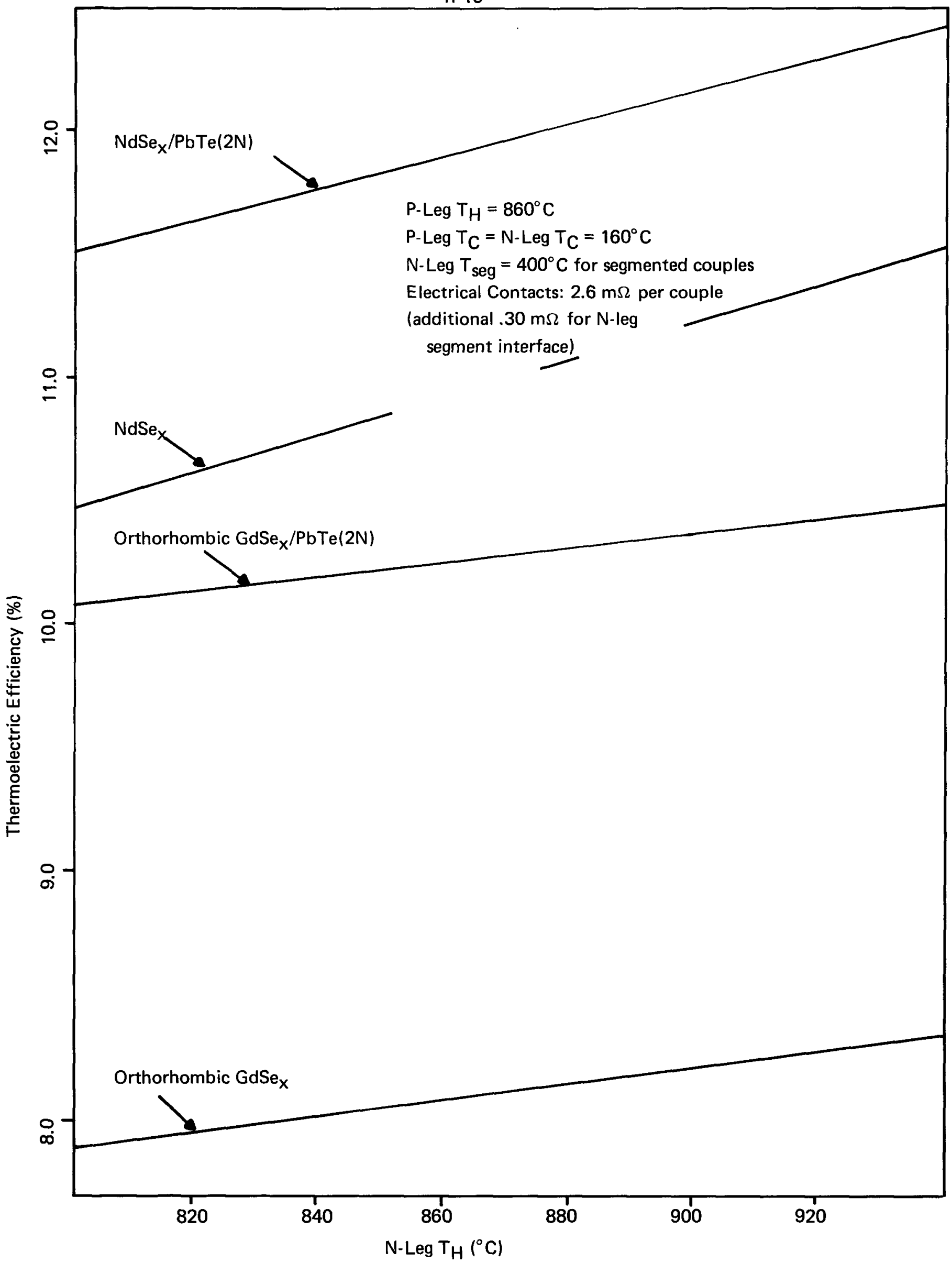

FIGURE II-11: THERMOELECTRIC EFFICIENCY VS. N-LEG HOT JUNCTION TEMPERATURE 


\section{B. EFFECTS OF POINT CONTACTS ON THE ELECTRICAL BEHAVIOR OF TPM-217}

Since P-leg carrier concentration is dependent upon current density, the occurrence of point contacts at either end of the leg could have a significant effect on its electrical behavior. A study to evaluate this effect was started but has not been completed. The following approach was taken.

An axisymmetric configuration was assumed. A one-dimensional resistivity distribution comparable to that of a P-leg operating at $860 / 160^{\circ} \mathrm{C}$ was imposed across the solution plane. The current density distribution was obtained with the use of a two-dimensional heat conduction program.

The only cases run thus far have been for constriction at the hot end of the leg. Three (3) solutions have been obtained: no constriction, constriction over $50 \%$ of the diameter, and constriction over $90 \%$ of the diameter. The results have not been analyzed, but a plot of the $50 \%$ solution is shown in Figure II-13. Since the carrier concentration throughout the P-leg is tied to the cold end, it is suspected that constriction at the cold end would be a more serious problem than constriction at the hot end. Post test observations of Module M-21 and other single-element tests have shown this to be a real possibility.

\section{HEAT FLOW THROUGH A CONVERTER}

1. Bypass Heat Flow Through a Converter

This calculation was made for the $\mathrm{SN}-1$ design. The objective was to determine the magnitude of the heat flux flowing around the elements and through the $\mathrm{Hi}-\mathrm{Fi}$ thermal insulation and through the P-leg slurry wrap. The details of the calculation are shown in Figure II-14. The bypass heat flux total of $221.5 \mathrm{~W}$ is higher than older estimates because the smaller $\mathrm{N}$-leg diameter for the segmented design has affected an increase in bypass area. This figure represents approximately $11 \%$ of the total available heat flux.

\section{Thermal Resistance of Cold End Hardware}

A thermal resistance calculation was made for the $\mathrm{SN}-1$ reference design cold end hardware. Details of the calculation are shown in Figures $\mid 1-15$, and $\mid 1-16$. The compression springs have not been included in the model. They were found to have a sufficiently high resistance so as not to be significant. The resistance figure $7.2^{\circ} \mathrm{C} / \mathrm{W}$ has been confirmed experimentally. Note that this does not include contact resistances but represents only the resistance of the hardware itself. 


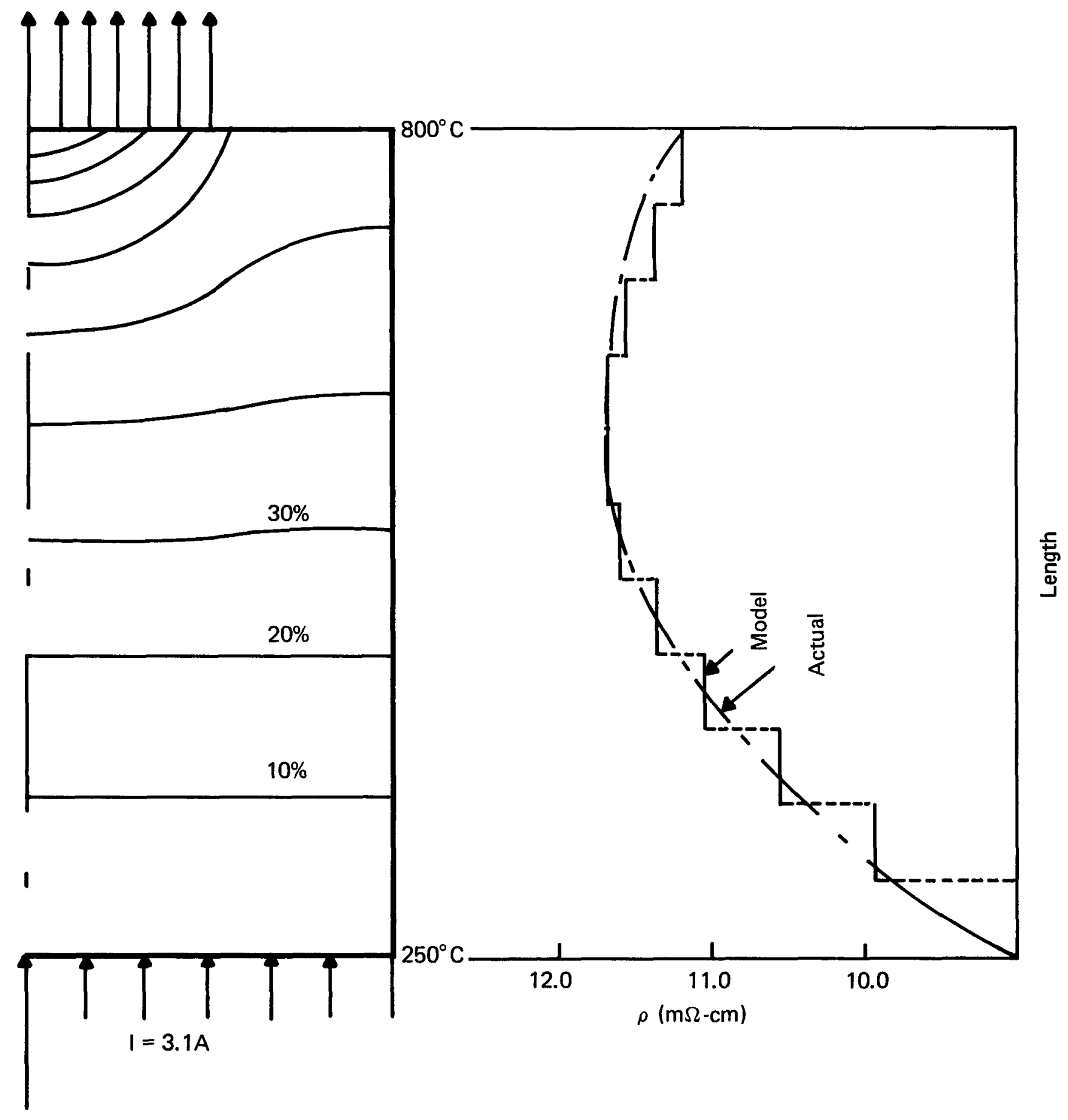

FIGURE II-13: P-LEG EQUIPOTENTIAL LINES FOR 75\% CONSTRICTION AND RESISTIVITY PROFILE USED IN CALCULATION 
The calculation of the bypass in the HiFi paper is based on the following assumptions:

- Width of insulation for two (2) rings

(from TES/3M Interface Drawing, No. SIG 116001)

$=2[3.00+2(.12)]=6.48$ inches

- Average diameter of Insulation

- Distance across POCO hot frame flats

$=8.117$ inches

- Hot strap thickness $\times 2$

$=0.136$ inches

- $1 / 2$ leg length $\times 2$

$=\underline{3.300 \text { inches }}$

8.553 inches

- Cut-outs for legs

- $\mathrm{N}$-Leg Diameter $=.200$

- P-Leg Diameter (with .025 thick wrap) $=0.310$

- 336 Couples

Heat Flow Area $=\pi(8.553)(6.48)-\pi / 4\left[(200)^{2}+(.310)^{2}\right] 336$

$=174.1-35.9=138.2 \mathrm{in}^{2}$

- Thermal conductivity of HiFi paper (15\% compression) measurements at Dynatech R/D Co. at $0 \%$ compression and $30 \%$ compression are .015 and $.013 \mathrm{BTU} / \mathrm{hr}-\mathrm{ft}-{ }^{\circ} \mathrm{F}$ respectively; therefore, the value of $.014 \mathrm{BTU} / \mathrm{hr}-\mathrm{ft}^{\circ}{ }^{\circ} \mathrm{F}$ will be used for $15 \%$ compression. The amount of compression of $15 \%$ was selected based on insulation compliance measurements performed at $3 \mathrm{M}$.

- Assumed hot frame temperature $=960^{\circ} \mathrm{C}$

- Assumed cold strap temperature $=160^{\circ} \mathrm{C}$

- Q $_{\text {Bypass }}(\mathrm{hiFi})=\mathrm{KA} \frac{\Delta \mathrm{T}}{\Delta \mathrm{X}}$

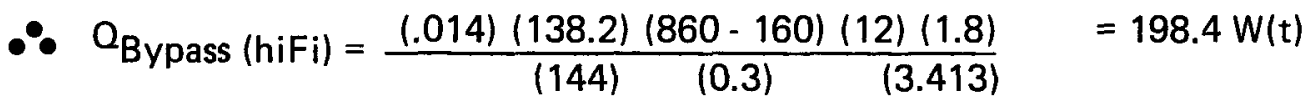

- Bypass in Wrap

- From Dynatech R/D Co. measurements

$$
\begin{gathered}
k_{\text {wrap }}=.030 \frac{\mathrm{BTU}}{\mathrm{hr}-\mathrm{ft}-{ }^{\circ} \mathrm{F}} \\
\therefore \mathrm{Q}_{\text {wrap }}=\frac{336}{144} \frac{\pi}{4}\left(.310^{2}-.260^{2}\right)(.030) \frac{(860-160)}{0.3} \frac{(12)(1.8)}{(3.413)}=23.1 \mathrm{~W}(\mathrm{t})
\end{gathered}
$$

- $\quad$ Total converter bypass $=198.4+23.1=221.5 \mathrm{~W}(\mathrm{t})$

FIGURE II-14: CALCULATION OF BYPASS HEAT FLOW WITHIN THE S/N-1 CONVERTER 


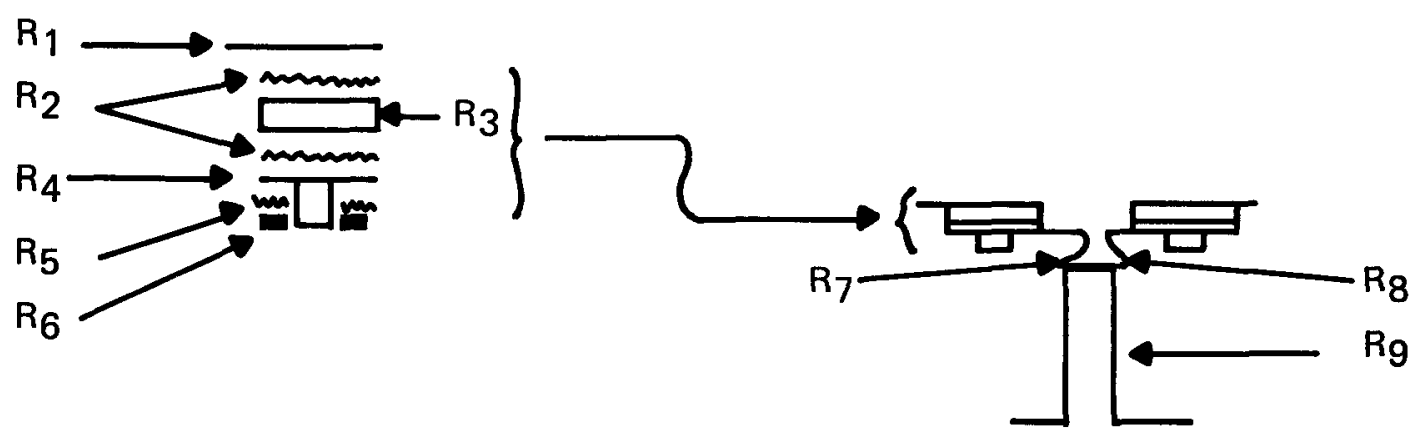

$R e=\sum_{i=1}^{7} R i$

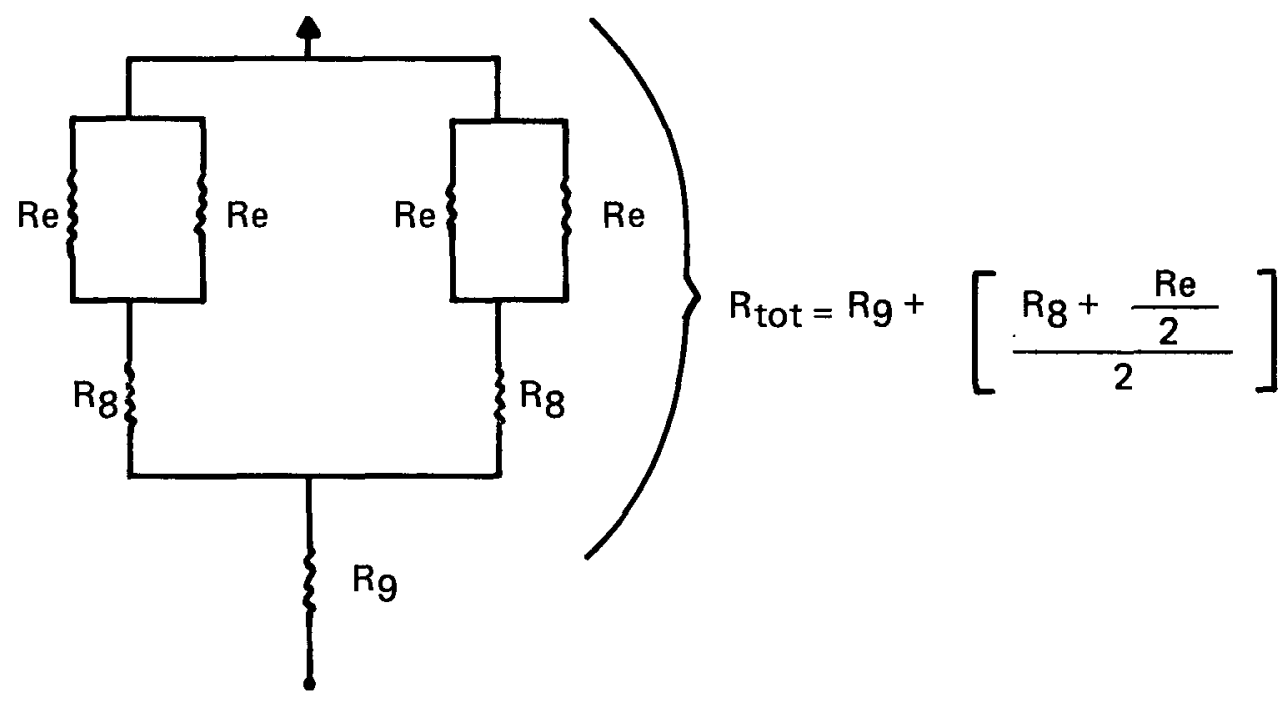

FIGURE II-15: COLD END HARDWARE ONE-DIMENSIONAL HEAT FLOW MODEL 


\section{CHARACTERIZATION OF DYNAMIC RESPONSE}

An effort was initiated with an independent support group within $3 \mathrm{M}$ to conduct a study to characterize the mechanical behavior of a converter ring in a dynamic environment. A mutual decision was made to use a lumped parameter model that would be analyzed by ANSYS, a general purpose finite-element structural analysis program. The effort was broken into two (2) sections: natural response and forced response. To date, the first of these has been completed.

A sketch of the lumped parameter model is given in Figure 11-17. The masses of one half of each spring and of all of the cold frame segments were lumped into the outer housing, and the mass of everything else was lumped into the hot ring. The compression springs were given both axial and lateral stiffness. The lateral stiffnesses were calculated from an equation given by Wahl in Vol. 2 of The Shock and Vibration Handbook by Harris and Crede. Figure II-18A describes the calculation.

The first phase of the study was to determine the natural frequencies for any resonance peaks that lie in the same range of the frequency domain as the JPL signal specifications. This determination was carried out without any damping included in the model. As a check on the accuracy of the numerical solution, the natural frequencies of three (3) simple mode shapes were calculated. The modes that were examined by hand are described in Figure $11-17$ and the calculations themselves are shown in Figure II-18B. The natural frequencies for pure torsion and for pure longitudinal motion are identical.

The agreement between ANSYS and the hand calculations was to within $2 \%$, so that the output looks sound.

A total of nine mode shapes were identified between 0 and $1200 \mathrm{cps}$. Of these, the first three were pure rigid body motions. Presently it is not known which of these modes are the most important. The forced response solution, which has not been obtained, would indicate that.

\section{E. THERMAL EXPANSION CALCULATIONS}

Thermal expansion calculations were performed for radial and longitudinal directions in a converter ring of the $\mathrm{SN}-1$ design. There is no circumferential expansion. The details of the calculations are shown in Figures II-19 and II-20. Notice from Figure II-19 that in order to simulate radial expansion for a full ring, it is necessary to overcompress an eighteen-couple assembly by 0.017 in. at room temperature.

\section{F. APPLIED STRESS VARIATIONS}

It is necessary to understand the force-displacement characteristics of the new cold end hardware so that the effect of thermal expansion, creep and tolerance variations in contact pressure can be determined. A summary of the forces on a thermoelectric element is given by a force balance on the thermoelectric leg and surrounding insulation (Figure II-21). 
1. Calculate $R$ for one rail of one cold frame segment:

$$
R=\left(R^{A} / L\right)-1
$$

Refer to Fig. 1 for meanings of $R_{1}, R_{2}, R_{3}, R_{4}, R_{5}$

\begin{tabular}{|c|c|c|c|c|c|}
\hline $\begin{array}{c}\mathrm{R} \\
\mathrm{W} / \mathrm{cm}-\mathrm{K}) \\
\end{array}$ & $\begin{array}{c}L_{1} \\
(\mathrm{~cm}) \\
\end{array}$ & $\begin{array}{l}\mathrm{L}_{2} \\
(\mathrm{~cm})\end{array}$ & $\begin{array}{c}A \\
\left(\mathrm{~cm}^{2}\right) \\
\end{array}$ & $\begin{array}{c}\mathrm{L} \\
(\mathrm{cm})\end{array}$ & $\begin{array}{c}\mathrm{R} \\
\left({ }^{\circ} \mathrm{C} / \mathrm{W}\right) \\
\end{array}$ \\
\hline 3.98 & - & - & .456 & .0267 & .0147 \\
\hline .346 & - & - & .456 & .0102 & .0646 \\
\hline 2.30 & - & - & .456 & .0787 & .0750 \\
\hline 3.98 & - & - & .456 & .0254 & .0140 \\
\hline .346 & - & - & .350 & .0051 & .0413 \\
\hline 3.98 & - & - & .350 & .0533 & .0383 \\
\hline 3.98 & 1.016 & .0533 & .0542 & .794 & 3.68 \\
\hline .346 & 1.14 & .356 & .406 & .005 & .0356 \\
\hline 1.71 & 2.11 & .356 & .750 & 1.02 & .7953 \\
\hline
\end{tabular}

$$
\begin{aligned}
& R e=R_{1}+R_{2}+R_{3}+R_{4}+R_{5}+R_{6}+R_{7}=3.93^{\circ} \mathrm{C} / \mathrm{W} \\
& R_{\text {tot }}=R g+\left(\frac{R_{8}+\frac{R e}{2}}{2}\right)=1.80^{\circ} \mathrm{C} / \mathrm{W}
\end{aligned}
$$

2. Calculate heat flux through one rail of one cold frame segment:

$$
\mathrm{Q} \cong \frac{(1126 \mathrm{~W} / \text { ring })}{(168 \text { Couples } / \text { ring })} \times(2 \text { Couples } / \text { rail })=13.4 \mathrm{~W}
$$

$\therefore \quad$ Expected $\triangle \mathrm{T}=\mathrm{QR}=24.1^{\circ} \mathrm{C}$

3. Now, what is the thermal resistance based on the heat flux through a single element:

$$
R=\Delta T / Q=\frac{24.1^{\circ} \mathrm{C}}{3.35 \mathrm{~W} / \text { Element }}=7.19^{\circ} \mathrm{C} / \mathrm{W}
$$

This figure is an acceptable thermal resistance. (The goal is $7^{\circ} \mathrm{C} / \mathrm{W} \pm 3^{\circ} \mathrm{C} / \mathrm{W}$ ). 

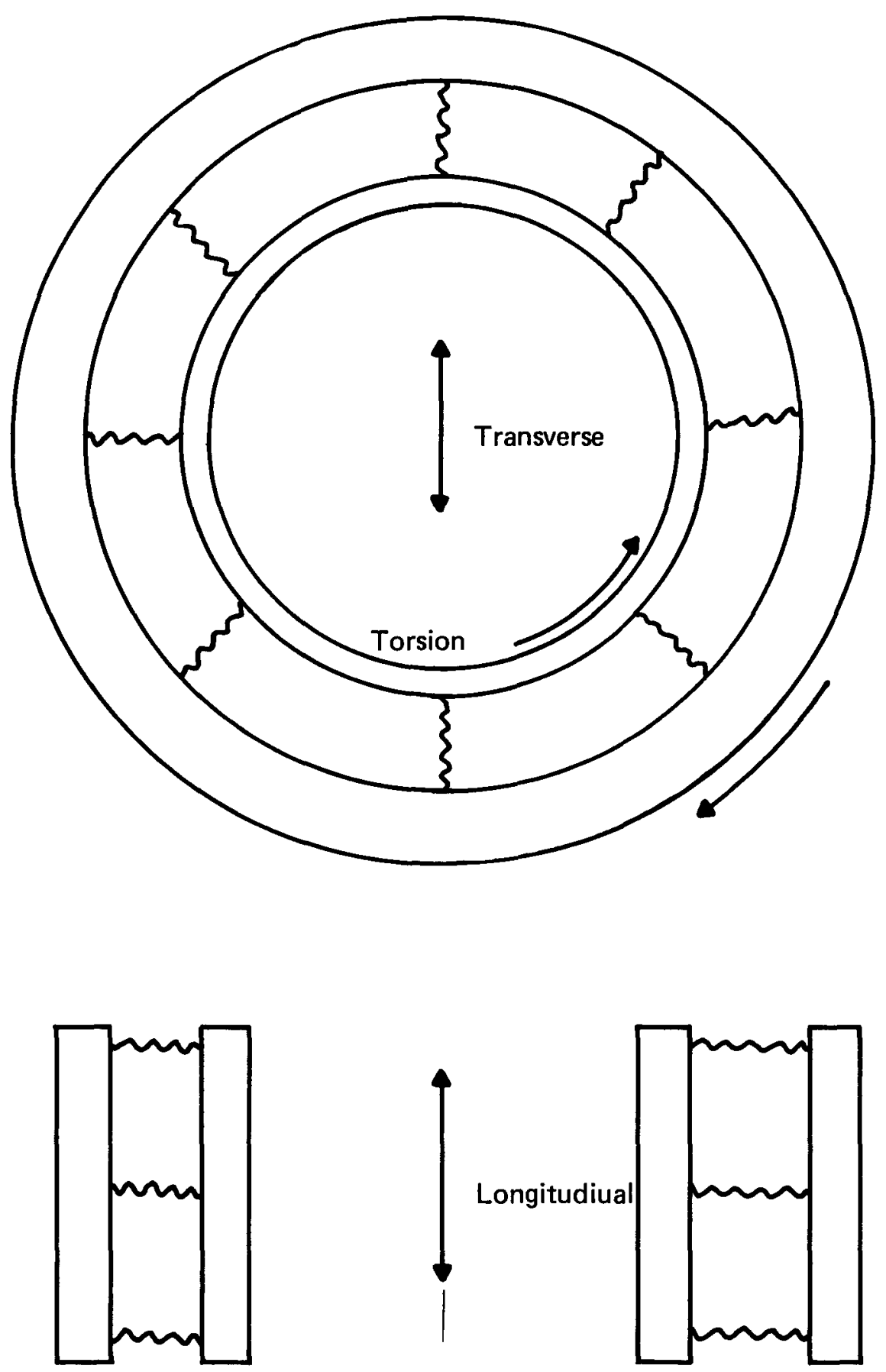

FIGURE II-17: A SKETCH OF THE LUMPED PARAMETER MODEL 


$$
K_{L}=\frac{10^{6} d^{4}}{\ln n D\left(.204 h_{s}^{2}+.265 D^{2}\right)} \quad, \frac{\text { lbs }}{\text { in. }} \text { * }
$$

$$
\begin{aligned}
\text { where } \mathbf{n} & =\text { Number of active coils } \\
\mathbf{d} & =\text { Wire diameter, [in] } \\
\mathrm{ST} & =\text { Axial deflection due to } \mathrm{F},[\mathrm{in}] \\
\mathrm{L}_{\mathrm{O}} & =\text { Free length, [in] } \\
\mathrm{C}_{\mathrm{L}} & =\text { A factor, see graph below } \\
\mathrm{D} & =\text { Wire diameter, [in] } \\
\mathrm{h}_{\mathbf{S}} & =\text { Operating height, }[\mathrm{in}]
\end{aligned}
$$
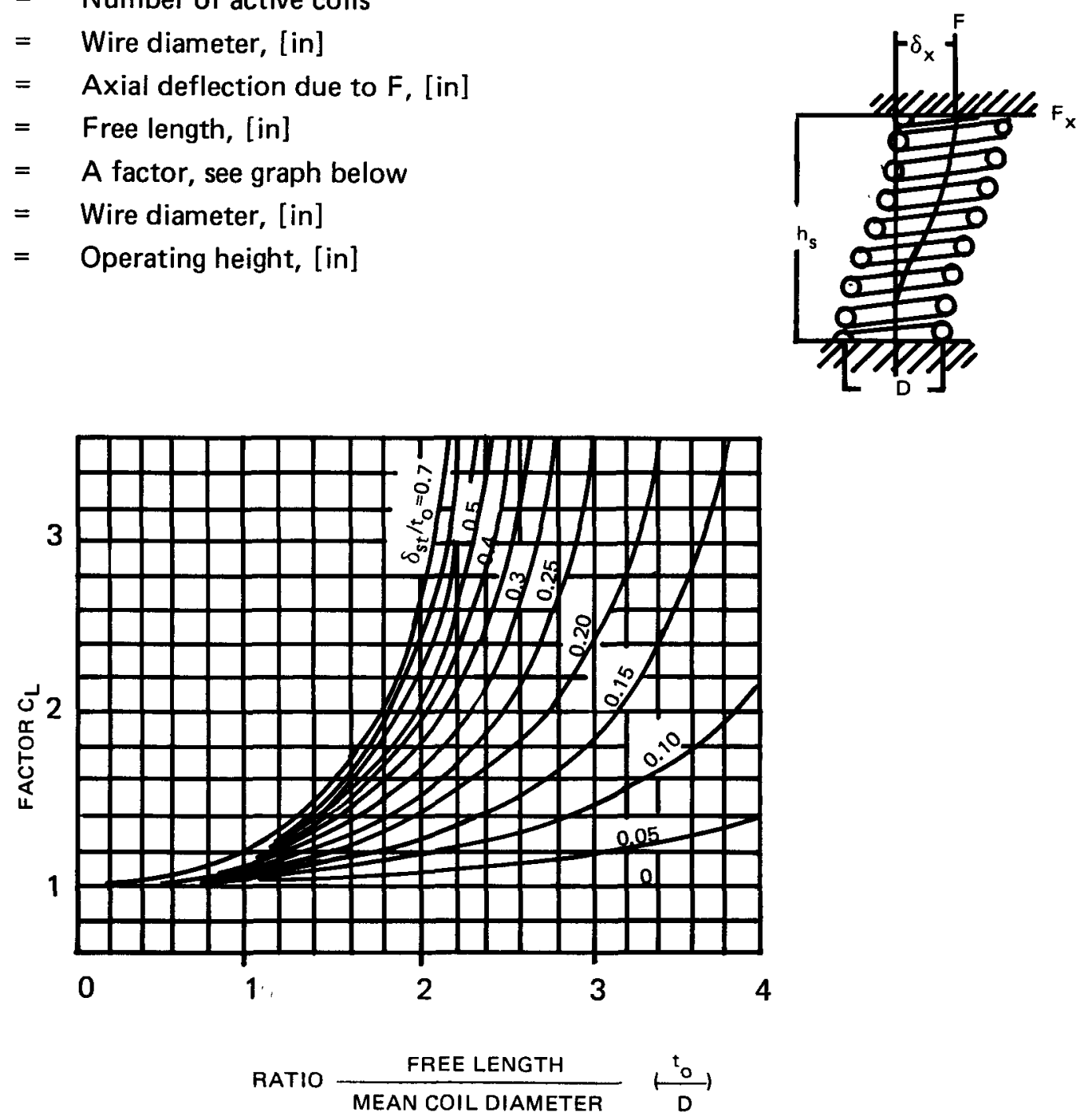

Lateral stiffnesses for $\mathrm{SN}-1$ springs

$$
\begin{aligned}
& \mathrm{N} \text {-leg }=46.4 \mathrm{lbs} . / \mathrm{in.}=38 \% \text { of axial stiffness } \\
& \text { P-leg }=17.2 \mathrm{lbs} . / \mathrm{in.}=17 \% \text { of axial stiffness }
\end{aligned}
$$

FIGURE II-18A: CALCULATION OF LATERAL STIFFNESS OF A COMPRESSION SPRING

* Only valid for steel springs with $E=30 \cdot 10^{6}$ psi and $G=11.5 \cdot 10^{6}$ psi 


\section{Assumptions}

$$
\text { Axial Spring Constants: } \begin{aligned}
& \mathrm{N}-\mathrm{Leg}=115.0 \mathrm{lbf} / \mathrm{in} . \\
& \mathrm{P}-\mathrm{Leg}=94.4 \mathrm{lbf} / \mathrm{in} .
\end{aligned}
$$

Lateral Spring Constants: $\quad \mathrm{N}-\mathrm{Leg}=46.4 \mathrm{lbf} / \mathrm{in}$.

$$
\text { P-Leg }=17.2 \mathrm{lbf} / \mathrm{in} \text {. }
$$

Mass of inner ring $=4.61 \mathrm{lbm}$

2. A. Lateral Motion of Inner Ring

$$
\begin{aligned}
& K_{a} \text { for 6-couple }=K_{a 6}=6\left(K_{a N}+K_{a P}\right)=6(115+94.4)=1256 \mathrm{lbf} / \mathrm{in} \text {. } \\
& \begin{aligned}
K_{L} \text { for 6-couple }=K_{L 6}=6\left(K_{L N}+K_{L P}\right)=6(46.4+17.2)=382 \mathrm{lbf} / \mathrm{in} . \\
K_{a} \text { for half of converter }=K_{a 6}\left[1+\sum_{i=1}^{7} 2 \cos ^{2}\left(\theta_{i-1}+12.86^{\circ}\right)\right], \theta_{0}=0^{\circ} \\
=7.00 K_{a 6}=8795 \mathrm{lbf} / \mathrm{in} .
\end{aligned}
\end{aligned}
$$

Similarly, $K_{L}$ for half of converter $=7.00 K_{L 6}=2671 \mathrm{lbf} / \mathrm{in}$.

$\therefore K$ for entire converter $=2(8795+2671)=22,932 \mathrm{lbf} / \mathrm{in}$.

$$
\begin{gathered}
\therefore \omega_{N}=\sqrt{\frac{(22,932 \mathrm{lbf} / \mathrm{in} .)(12 \mathrm{in} / \mathrm{ft})(32.2 \mathrm{lbm} / \mathrm{s} / \mathrm{ug})}{(4.61 \mathrm{lbm})}} \\
=1386 / \mathrm{s}=221 \mathrm{~Hz}
\end{gathered}
$$

B. Torsional Motion and Longitudinal Motion of Inner Ring

$K$ for entire converter $=28 K_{L 6}=10,696 \mathrm{lbf} / \mathrm{in}$

$$
\therefore \omega_{N}=\sqrt{\frac{(10,696)(12)(32.2)}{(4.61)}} \quad=947 / \mathrm{s}=151 \mathrm{~Hz}
$$


A. Full connector ring.

1. Estimation of change in stack height.

Temp. of hot frame $=860+25=885^{\circ} \mathrm{C}$

$\triangle D$ Hot Frame $=\left(8.09 \cdot 10^{-6} /{ }^{\circ} \mathrm{C}\right)(885-20)(8.117 \mathrm{in.})=+.057 \mathrm{in}$.

Temp. of cold frame $-150-25=125^{\circ} \mathrm{C}$

$\Delta D$ cold frame $=\left(13.0 \cdot 10^{-6} /{ }^{\circ} \mathrm{F}\right)\left(125-20^{\circ} \mathrm{C}\right)\left(1.80^{\circ} \mathrm{F} /{ }^{\circ} \mathrm{C}\right)(10.159 \mathrm{in})=.+.025 \mathrm{in}$.

$\therefore \Delta$ Stack height $=1 / 2(.025-.057)=-.016 \mathrm{in}$.

$\therefore$ the stack height decreases by .016 in.

2. Estimation of change in spring height:

a) N-Leg

T Hot strap $=1 / 2(885+860)=875$

$\Delta \mathrm{L}$ Hot strap $=\left(30 \bullet 10^{-7} /{ }^{\circ} \mathrm{F}\right)\left(873-20^{\circ} \mathrm{C}\right)\left(1.80^{\circ} \mathrm{F} /{ }^{\circ} \mathrm{C}\right)(.1 \mathrm{in})=.+.0005 \mathrm{in}$.

Tn-leg $=1 / 2(860+160)=510$

$\Delta \mathrm{L} \mathrm{N}$-Leg $-\left(10 \bullet 10^{-6} /{ }^{\circ} \mathrm{C}\right)\left(510-20^{\circ} \mathrm{C}\right)(.3 \mathrm{in})=$.

$\Delta \mathrm{L}$ cold strap, follower $=\left(10 \bullet 10^{-6} /{ }^{\circ} \mathrm{F}\right)\left(150-20^{\circ} \mathrm{C}\right)\left(1.80^{\circ} \mathrm{F} /{ }^{\circ} \mathrm{C}\right)(.011+021$ in. $)$

$=+.0001$ Negligible

$\Delta \mathrm{L} \mathrm{BeO} \mathrm{disc}=\left(5.5 \cdot 10^{-6} /{ }^{\circ} \mathrm{C}\right)\left(150-20^{\circ} \mathrm{C}\right)(.030 \mathrm{in})=..00002-$ Negligible

$\therefore \Delta \mathrm{L}$ spring $=\Delta$ Stack ht. $-\Sigma \Delta \mathrm{L}$ 's

$=-.016-.0005-.0015$

$=-.018 \mathrm{in}$.

$\therefore$ the operating $\mathrm{N}$-Leg spring height decreases by .018 in. during heat-up in a full converter ring.

b) P-Leg

$\Delta \mathrm{L}$ Hot strap $=\left(30 \bullet 10^{-7} /{ }^{\circ} \mathrm{F}\right)(873-20)(1.80)(.068)=.0003 \mathrm{in}$.

$\Delta L$ P-Leg $=\left(20 \bullet 10^{-6} /{ }^{\circ} \mathrm{C}\right)(510-20)(0.30)=.0029$ in.

$\therefore \Delta \mathrm{L}$ spring $=-.016-.0003-.0029$

$=-.019$

$\therefore$ The operating P-Leg spring height decreases by .019 in. during heat-up in a full converter ring.

B. Eighteen couple module

1. Estimation of change in stack height.

Temp. of hot frame $=885^{\circ} \mathrm{C}$

$\Delta \mathrm{L}$ Hot frame $=\left(8.09-10^{-6} / \mathrm{C}\right)(885-20)(1.250 \mathrm{in})=..0087 \mathrm{in}$.

Temp. of tantalum pins $=1 / 2\left(885+125^{\circ} \mathrm{C}\right)=505^{\circ} \mathrm{C}$

$\Delta L$ pins $=\left(3.60 \bullet 10^{-6} /{ }^{\circ} \mathrm{F}\right)\left(505-20^{\circ} \mathrm{C}\right)(1.80)(3.22 \mathrm{in})=..0101 \mathrm{in}$.

$\therefore \Delta$ Stack height $=.0101-.0087=+.0014 \mathrm{in}$.

$\therefore$ The stack height increases by .0014 in.

FIGURE II-19: CALCULATION OF THERMAL EXPANSION ALONG THE STACK 
2. Estimation of change in spring height.

a) N-Leg

As before, $\Delta L$ Hot strap $=.0005$ in.

$\triangle \mathrm{LN}$-Leg $=.0015 \mathrm{in}$.

$\therefore \Delta \mathrm{L}$ spring $=.0014-.0005-.0015=-.001 \mathrm{in}$.

$\therefore$ The $\mathrm{N}$-leg spring length decreases by $.001 \mathrm{in}$. in an eighteen couple module during heat-up.

b) P-Leg

As before, $\triangle L$ Hot strap $=.0003$ in.

$\triangle L$ P-leg $=.0029$ in.

$\therefore \Delta L$ spring $=.0014-.0003-.0029=-.002$

The P-leg spring length decreases by .002 in. in an eighteen couple module during heat-up.

FIGURE II-19: CALCULATION OF THERMAL EXPANSION ALONG THE STACK (Continued) 


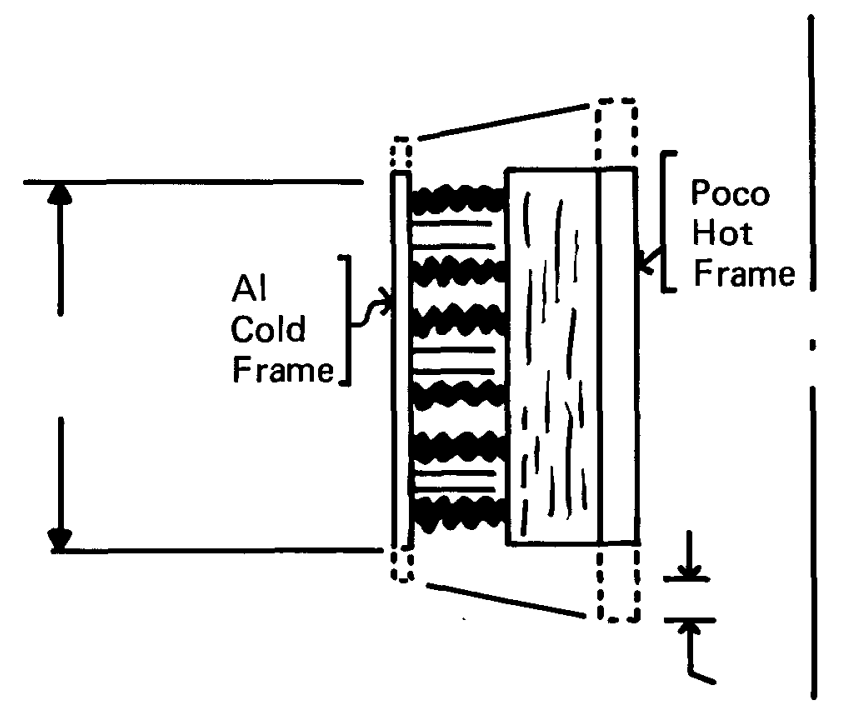

* Solid lines indicate configuration at $T_{\text {ref }}$

Dotted lines indicate configuration at operating temperatures

$$
\begin{aligned}
& \text { Assume: } \begin{array}{l}
\text { Hot Frame Temperature }=885^{\circ} \mathrm{C} \\
\text { Cold Frame Temperature }=125^{\circ} \mathrm{C}
\end{array} \\
& =\quad \text { POCO }\left(T_{H}-T_{\text {ref }}\right) \mathrm{L}-\mathrm{A} 1\left(\mathrm{~T}_{\mathrm{C}}-\mathrm{T}_{\text {ref }}\right) \mathrm{L} \quad / 2 \\
& =\quad\left(8.0910^{-6} /{ }^{\circ} \mathrm{C}\right)(885-20)\left(3^{\prime \prime}\right)-\left(13.010^{-6} /{ }^{\circ} \mathrm{C}\right)(125-20)\left(3^{\prime \prime}\right) \quad / 2 \\
& =\quad .008 \mathrm{in} .
\end{aligned}
$$




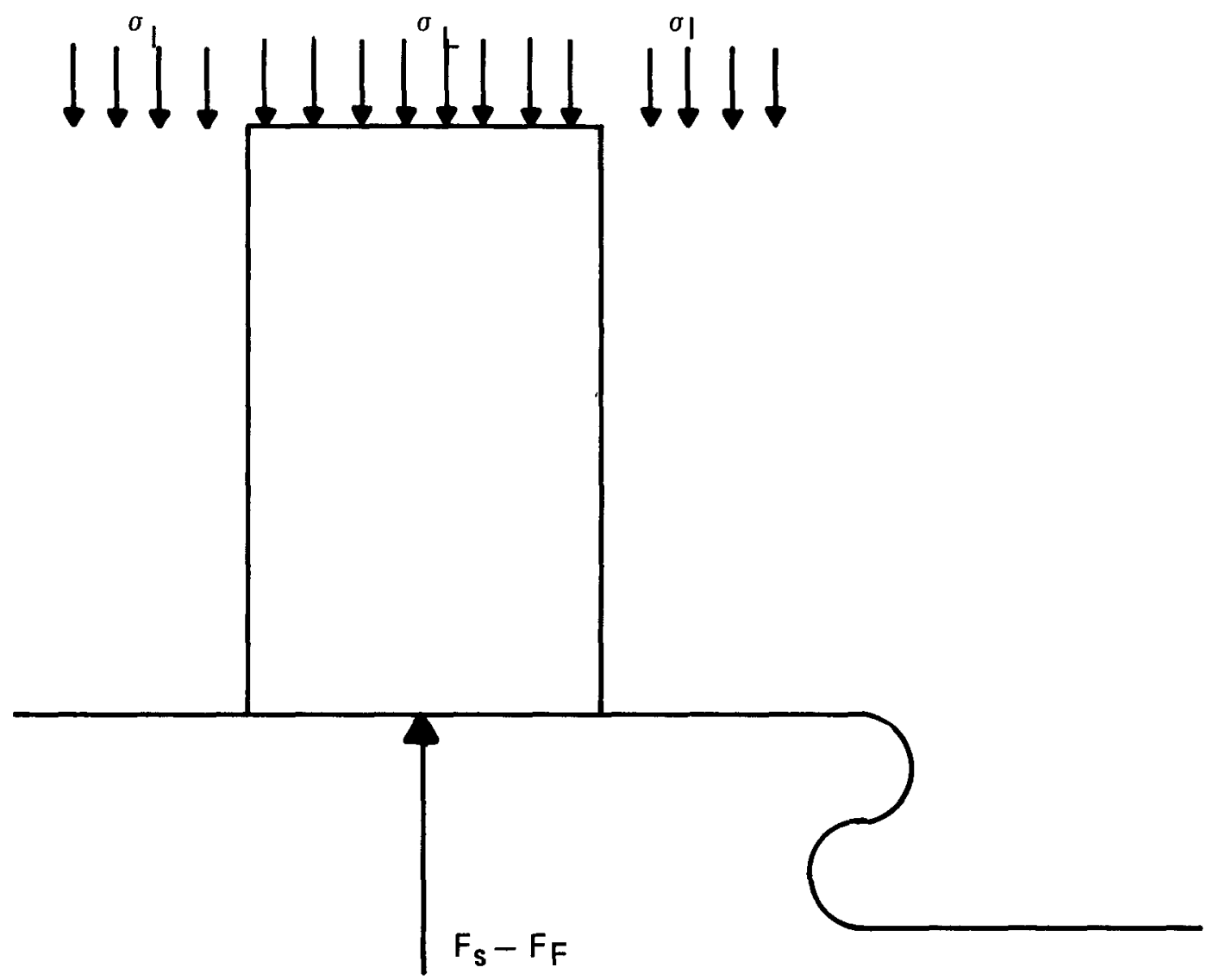

FIGURE 11-21: FORCE BALANCE ON LEG AND SURROUNDING INSULATION 


$$
\begin{aligned}
& F_{T O T}=F_{S}-F_{F}=F_{L}+F_{I}=\sigma_{L} A_{L}+\sigma_{1} A_{I} \\
& \therefore F_{L}=\frac{1}{A_{L}} \quad\left(F_{S}-F_{F}-\sigma_{\mid} A_{\mid}\right)
\end{aligned}
$$

where

$$
F_{s}=F_{s i}-K\left(L-L_{i}\right)
$$

where $\quad \begin{array}{lll}F_{S} & = & \text { Spring Force } \\ F_{s i} & = & \text { Initial Spring Force (Nominal Compression) } \\ F_{F} & =\text { Effective Spring/Friction Force of Follower } \\ F_{L}= & \text { Net Force on Leg } \\ F_{I}= & \text { Net Force on Insulation Surrounding Leg } \\ \sigma_{1} & =\text { Stress on Insulation as a Result of Compression } \\ \sigma_{L} & =\text { Net Stress or Contact Pressure on Thermoelectric Leg } \\ K & =\text { Spring Constant of Follower Spring } \\ L_{1} & =\text { Length of Follower Spring } \\ L_{1} & =\text { Initial Length of Follower Spring (Nominal Compression) } \\ A_{I} & =\text { Cross-Sectional Area of Thermal Insulation Associated with one } \\ A_{L} & =\text { Cross-Sectional Area of Thermoelectric Leg }\end{array}$

The stress on the insulation as a function of compression was measured using a special enclosing fixture and an Instron mechanical test machine. These data are shown plotted in Figure $11-22$ and a least squares curve fit to the data is given by:

$$
\sigma_{1}=a_{1}+a_{2} \epsilon_{1}+a_{3} \epsilon^{2}+a_{4} \epsilon_{1}^{3}+a_{5} \epsilon_{1}^{4}
$$

where $\quad \epsilon_{\mid}=1-L_{\mid} / L_{0}$

$$
\begin{aligned}
& \text { where } L_{1}=\text { Length of Insulation (Between Hot and Cold Straps) } \\
& \mathrm{L}_{\mathrm{o}}=\text { Unstressed Insulation Thickness }
\end{aligned}
$$

The measurements of the force-displacement characteristics of the follower were obtained in a spring test device. A typical force-displacement curve is shown in Figure II-23. The spring characteristics of the follower spring are obtained from $\mathrm{QC}$ measurements which are routinely performed on the springs. All of the components of the force balance described in equation (8) are thus combined and the results are shown in Figure II-24 as a function of follower deflection. Follower deflection will either occur from thermal expansion, P-element creep or sublimation. The actual compression of the follower spring at assembly is a function of the tolerance stack-up of components in the N- or P-leg stack. The effects for the extreme tolerance stack-up conditions are shown in Figures II-25 and II-26. 


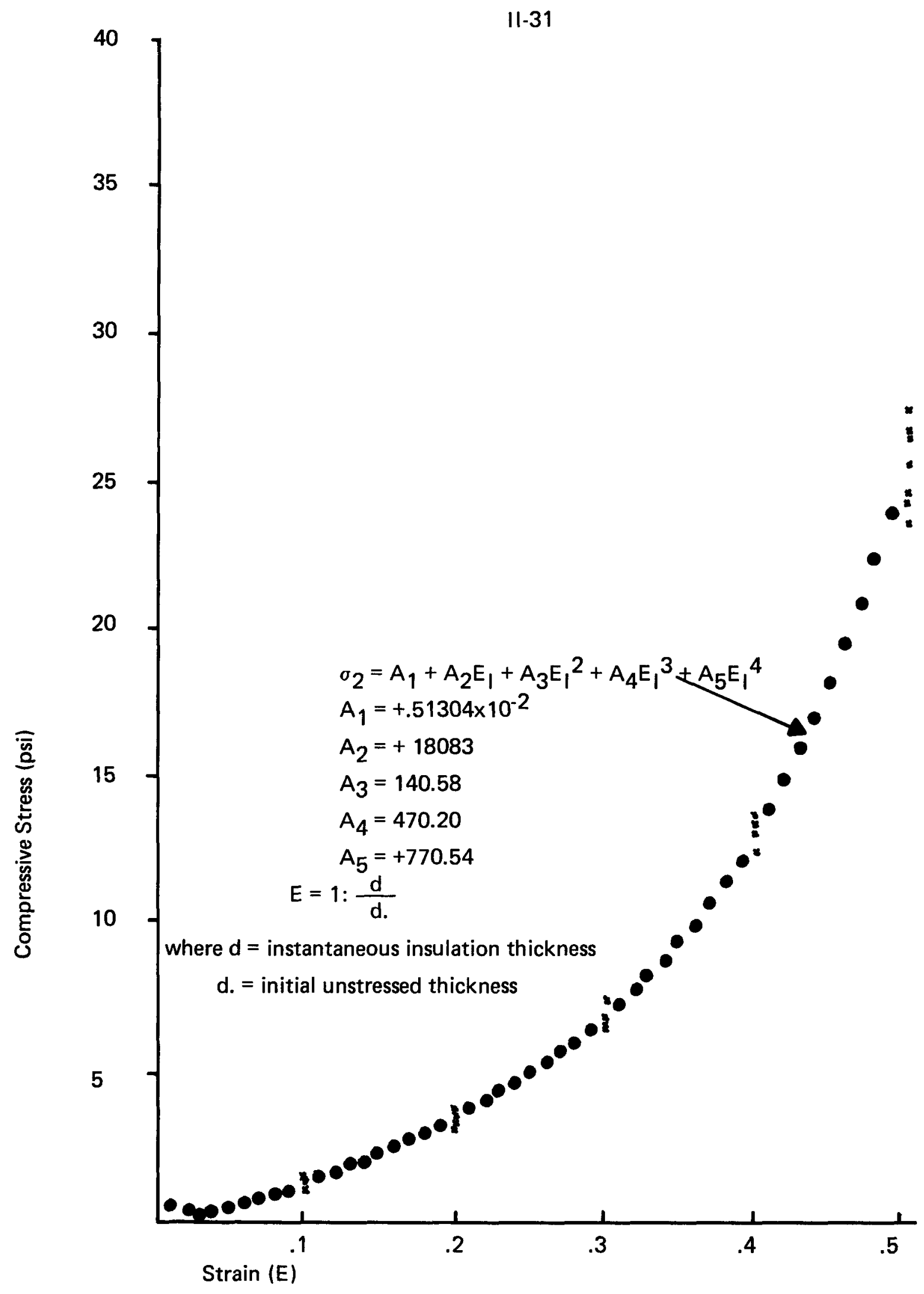

FIGURE II-22: STRESS VS. STRAIN DATA LAYERED Hi-Fi 660 PAPER

1 " THICK TEST SECTIONS NOMINALLY

4TH ORDER POLYNOMIAL FIT 
It can be seen that the minimum value for $\mathrm{N}$-leg contact pressure at 10 mils deflection is about $200 \mathrm{psi}$ and the minimum value for contact pressure on the P-leg at 30 mils deflection is about $30 \mathrm{psi}$. These values should be the maximum amount as a result of thermal expansion and/or creep/sublimation. Measurements have shown that this will still be an acceptable amount of contact pressure for each of the elements.

\section{G. N-LEG THERMAL STRESS ANALYSIS}

In order to get some indication of the role of thermal stresses in N-leg cracking, a study was initiated to characterize them. It was decided that a numerical study would be the best way to study the problem. ANSYS, the same general purpose program used for dynamic characterization, has been used thus far. To date only one solution has been obtained. The problem treated was an unsegmented cubic $\mathrm{GdSe}_{\mathbf{x}} \mathrm{N}$-leg with a one-dimensional temperature profile. The results obtained are being studied and verification of the results is being sought.

It has not yet been possible to study the effects of the transformation process on the thermal stresses in the $\mathrm{N}$-legs because the orthorhombic material has not been characterized for mechanical properties. In addition to characterizing the orthorhombic material, $\mathrm{NdSe}_{x}$ and (2N) PbTe need to be characterized.

\section{H. CALCULATION OF THE MAXIMUM STRESS LEVEL IN THE POCO HOT RING}

An estimate of the maximum stress in the graphite hot ring was determined by the following procedure (refer to Figure II-27).

1. Treat one-half of a ring

2. Neglect facets and pinholes (treat as a hemi-cylinder) and solve for reaction forces. These reactions correspond to the internal compressive stress in the system.

3. Using this stress as the applied stress, calculate the maximum stress using a concentration factor that is obtained from standard graphs available in the literature.

The results obtained indicates that $\sigma \max =3279 \mathrm{psi}$. Since the compressive strength of graphite AFX-Q1 is 22,000 psi, there is a safety margin of 6.7 inherent in the design. 


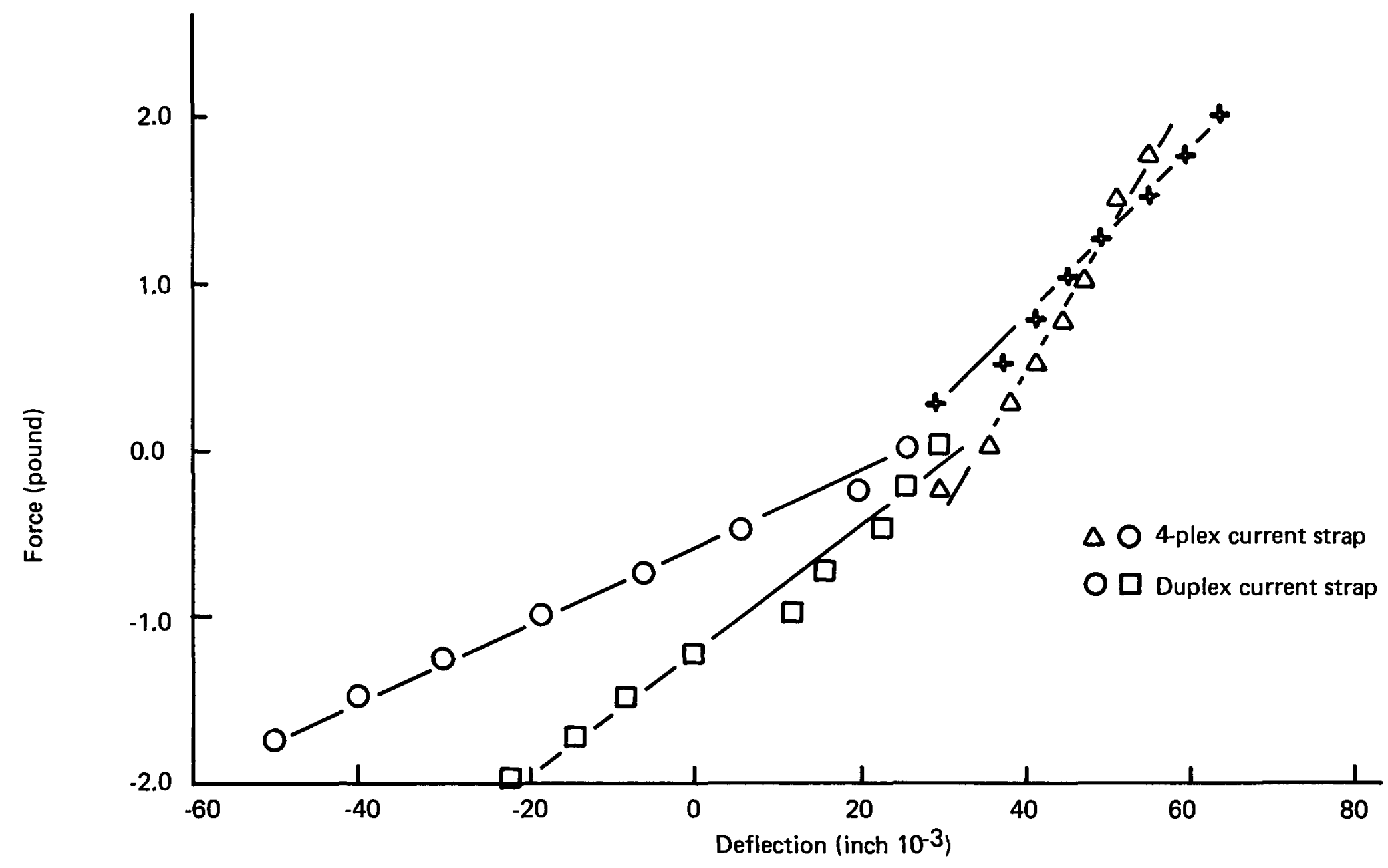

FIGURE 11-23: COMPLETE COLD END ASSEMBLY FORCE VS. DEFLECTION 


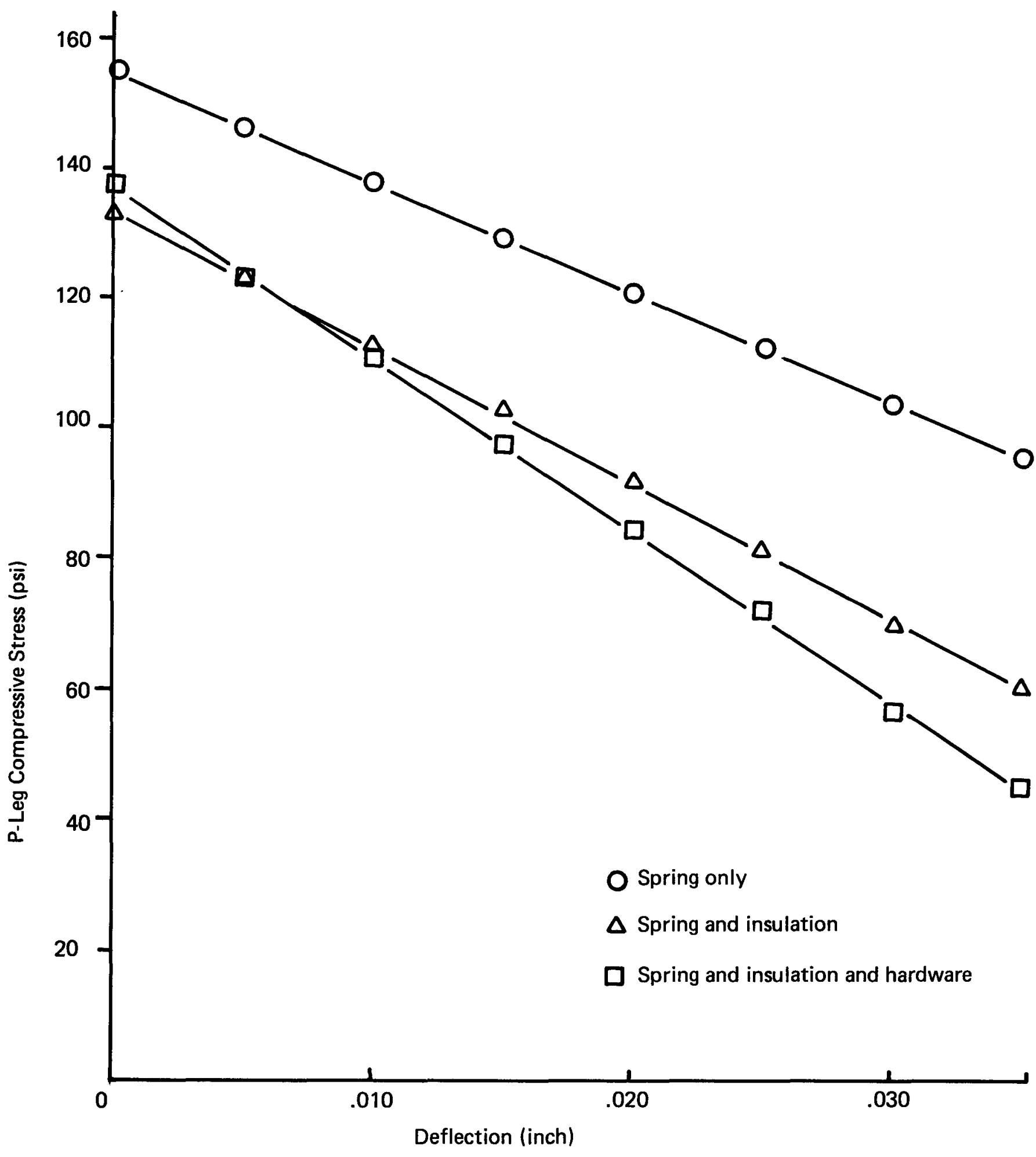

FIGURE II-24: INDIVIDUAL COMPONENTS OF FORCE BALANCE ON THERMOELECTRIC LEG 


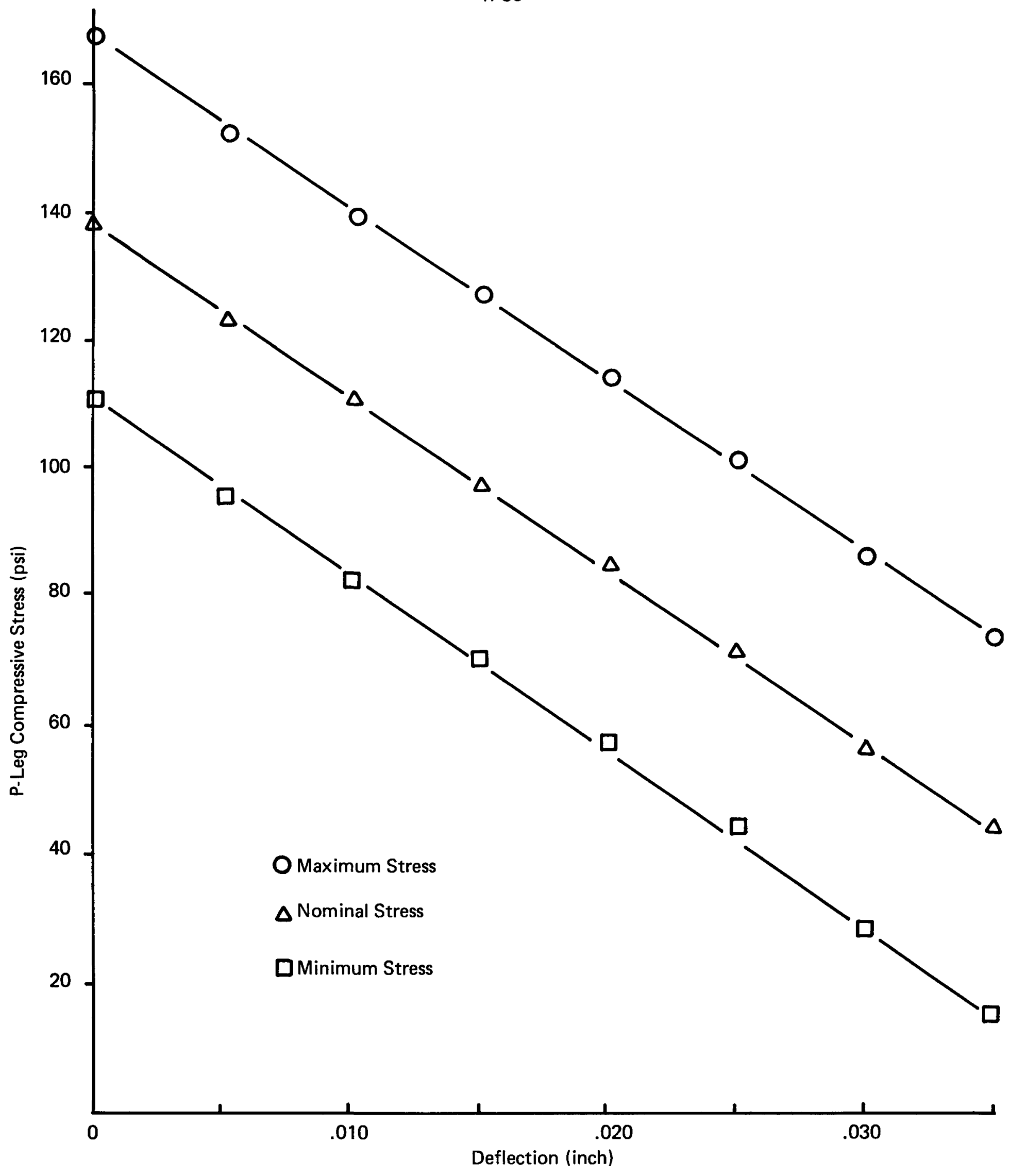

FIGURE II-25: P-LEG COMPRESSIVE STRESS VS. DEFLECTION 


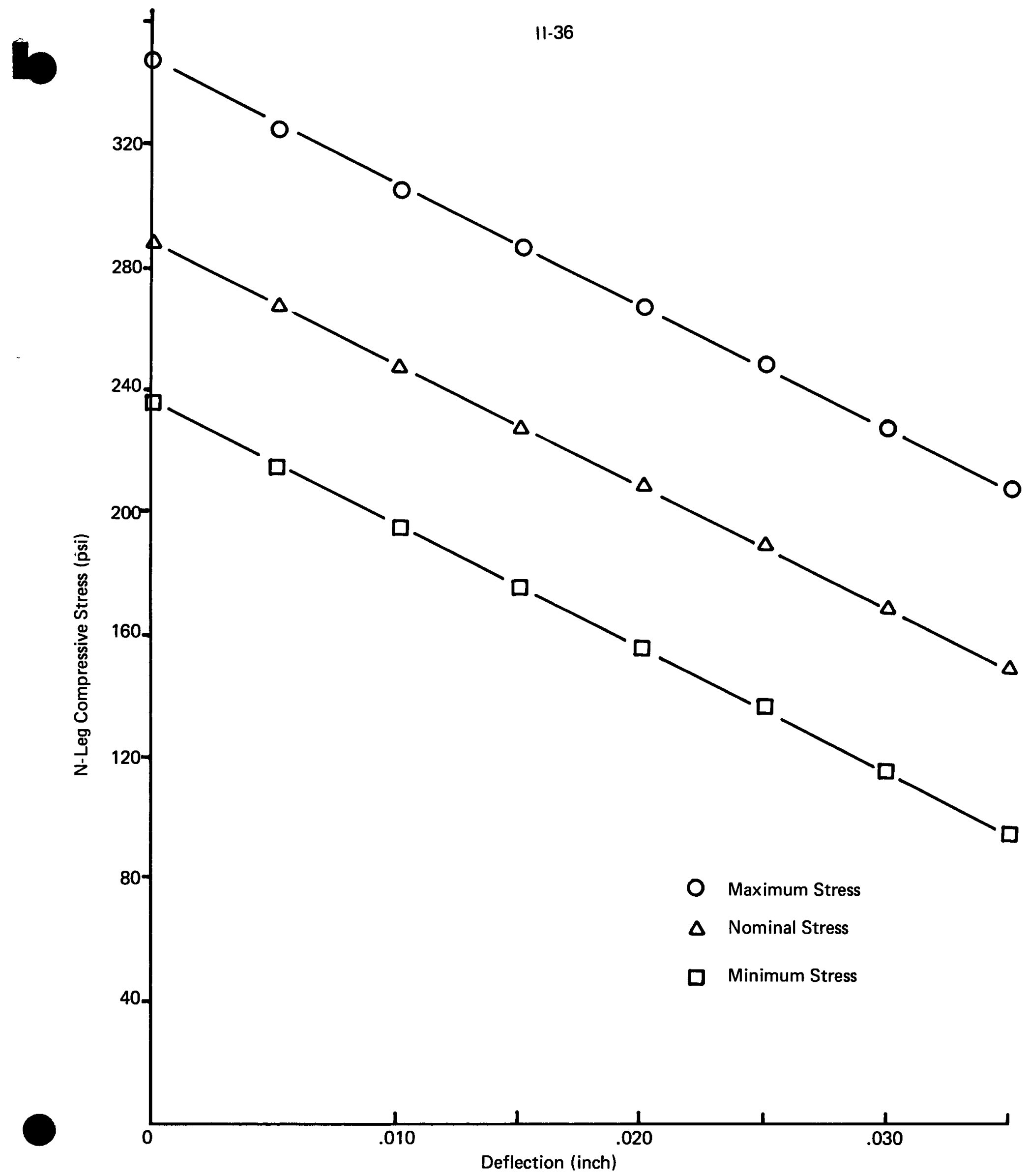

FIGURE II-26: N-LEG COMPRESSIVE STRESS VS. DEFLECTION 
Use one-half of the ring and neglect facets and pin-holes:

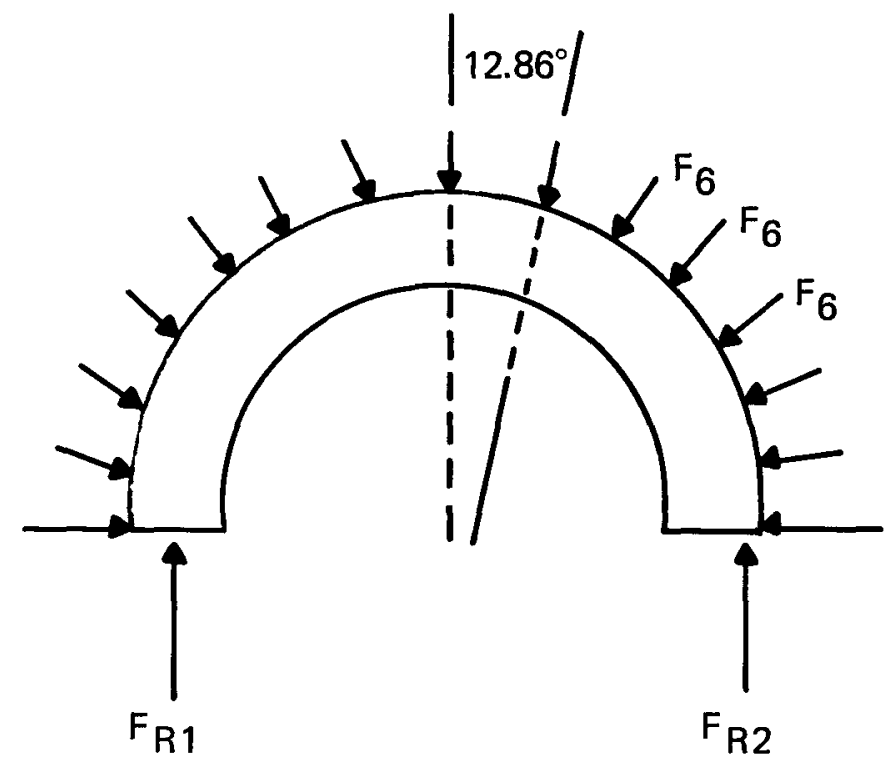

1. Calculate engineering stress (neglect holes and facets).

Cross-sectional area $=3.00$ in. $\times .230^{\prime \prime}=.690 \mathrm{in}^{2}$

$F_{6}=6(23.4)+6(8.5)=191.4 \mathrm{lbs}$.

$F_{R T}=F_{R 1}+F_{R 2}$

$F_{R T}=F_{6}\left[1+\sum_{i=1} 2 \operatorname{Cos}\left(\theta_{i-1}+12.86^{\circ}\right)\right], \theta_{0}=0^{\circ}$

$=\quad 7.88 \mathrm{~F}_{6}$

$=1508 \mathrm{lbs}$.

From symetry, $F_{R 1}=F_{R 2}=\frac{1508}{2}=754 \mathrm{lbs}$.

$\therefore \gamma \mathrm{e}=\frac{754 \mathrm{lbs} .}{.690 \mathrm{in}^{2}}=1093 \mathrm{psi}$

FIGURE 11-27: FREE BODY DIAGRAM FOR CALCULATING ENGINEERING STRESS IN RING 
2. Account for pin-holes through assignment of a stress concentration factor. Various graphs appearing in "Stress Concentration Factors" by Peterson, Wiley Interscience, 1974 were used in arriving at a rough estimate of 3 . See Figure 2 for pin-hole layout.

$\therefore$ Estimated maximum stress in Graphite hot ring $=3(1093)=3279$ psi

3. Compare w/Compressive strength of AFX-Q1 Graphite (POCO)

Temp - 22,000 psi

$\therefore$ Estimated safety margin $=\frac{22000}{3289}=6.71$

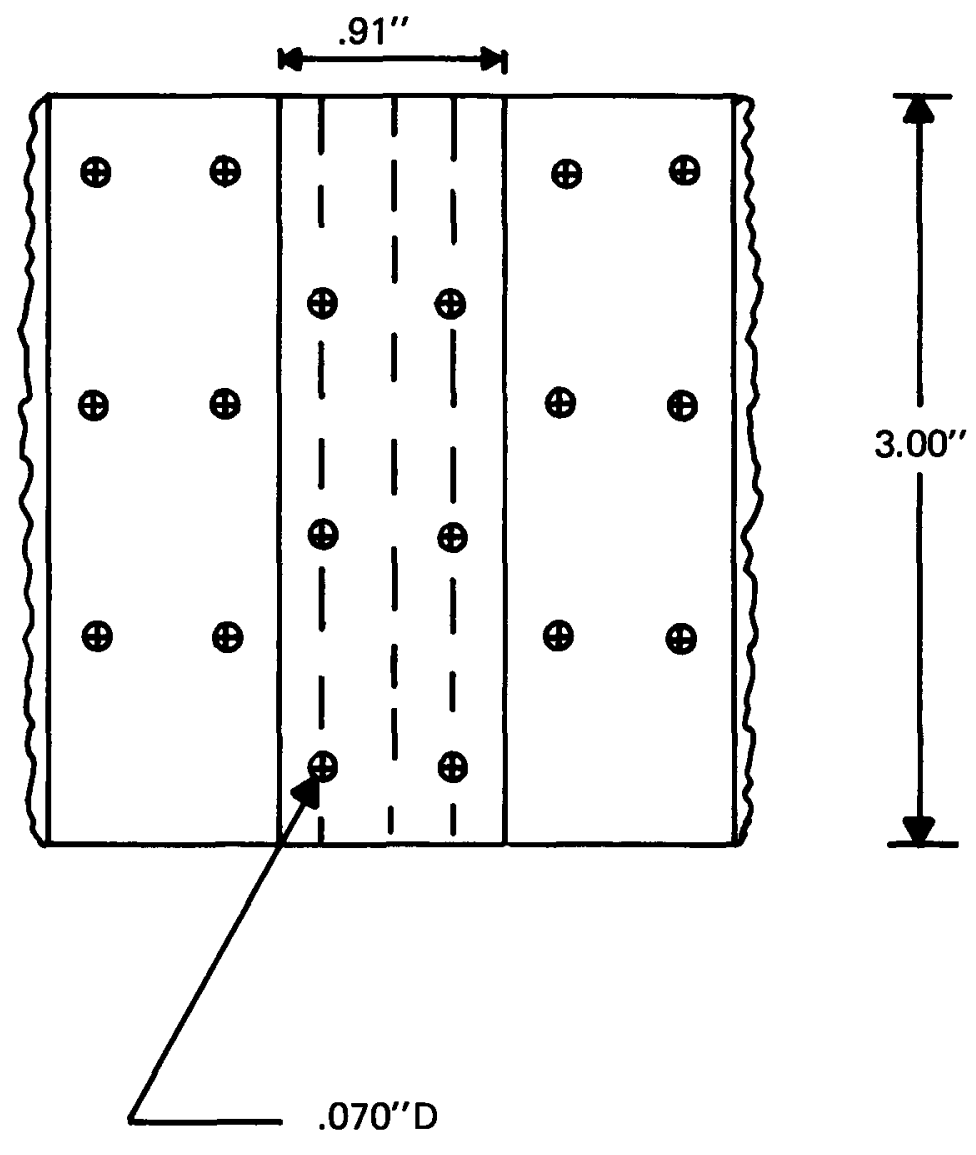

FIGURE II-27: Continued

PIN HOLE LAYOUT 


\section{SYSTEM TESTING}

\section{A. SPRING LOAD RELAXATION}

A compilation of spring load relaxation data appears in Figure III-1. In the course of 20,000 hours of exposure, M-7 springs experienced an almost complete loss of load. This degree of load relaxation was far in excess of existing load relaxation vs. time data available in the literature. Springs from other modules had higher than expected load losses, though none were as dramatically high as M-7. The fundamental differences between the conditions in which the module springs and the literature springs were tested were that the module springs were operated in an oxygen free environment (either vacuum or inert backfill, depending on the module) and were also subjected to Selenium vapor. Spring tests described in the literature took place in air.

A series of load relaxation tests were planned and run. These tests, which were intended to be diagnostic tests, are described and their results displayed in Table III-1. The air data is in acceptable agreement with the literature, and the vacuum plus Selenium data is in good agreement with the module data. Comparison of the vacuum only data with the vacuum plus Selenium data indicates that the presence of Selenium is not the key. This conclusion has been backed up by a number of chemical analyses. X-ray flourescence tests were conducted to obtain an overall Selenium content measurement, and whereas there was Selenium present on all springs, there was no correlation between Selenium pickup and load relaxation. Oak Ridge Labs determined that all of the Selenium pickup occurs at the surface in the form of a very thin film of Iron Selenide. The fact that this film is not a contributor to load relaxation was demonstrated with dip tests performed at $3 \mathrm{M}$.

Microhardness tests performed by both $3 \mathrm{M}$ and Oak Ridge showed that hardness changes occurred throughout the cross-sections of the springs. Also, metallographic analysis performed by Oak Ridge showed grain enlargement throughout the crossection, an observation consistent with the microhardness tests.

It is important to mention that M-7 springs were slightly under designed with respect to load relaxation considerations. It is estimated that the BOL corrected stress in the $\mathrm{N}$-leg springs was $130 \mathrm{ksi}$. This could be the reason why M-7 springs relaxed more than other modules, but at this point enough information to make this statement conclusively is not available. It appears that one reason all module springs relaxed more than expected was that the absence of oxygen seemed to accelerate load relaxation rate, but again, at present there is not enough information to explain why this occurs.

The observation of grain enlargement in the module springs that were examined indicates that the operating temperature was too high for ASTM A-401 Cr-Si steel, the material used for modules M-7 through M-18. Presently, 17-7 PH stainless steel is being used for module springs. Test data indicates that $17-7$ relaxes only about $50 \%$ as much as $\mathrm{Cr}$-Si under identical conditions and test durations. Even though 17-7 shows superior performance with respect to $\mathrm{Cr}$-Si, other materials are being looked into, e.g. Inconel X, MP-35N and Elgiloy. To date springs of these materials have not been tested, but designs have been made and springs have been ordered for continuation under the Technology Program. 


\section{B. CONVERTER TO HOUSING INTERFACIAL $\triangle T$}

A number of tests have been conducted to characterize the thermal resistance of the interface between the cold frame segment and the outer housing. For all experiments, the outer housing was modeled by a $6064 \mathrm{~A} 1$ chill block tailored to match the convex surface of the cold frame segment and polished to a $16 \mu$ " RMS surface finish. Temperature drops across the interface were measured with teflon insulated .003" D Iron-Constantan thermocouples embedded .030 in. from the interface on either side. The results are compiled in Tables III-2 and III-3. The contact pressures shown in the table correspond to the use of six $24 \mathrm{lb}$. N-leg springs and six $8.5 \mathrm{lb}$. P-leg springs.

A few conclusions can be drawn from these results. First, the change from 2024 to $6061 \mathrm{~A} 1$ apparently has no effect on thermal resistance at the interface. Second, the presence of a ductile intermediate layer in test number 3 significantly reduces the thermal resistance. The relatively wide spread in the data could be attributed to a number of things: differences in mean temperature, variability in degree of oxidation of the aluminum surfaces from test to test, and large uncertaintly $( \pm 10 \%)$ in the contact pressure.

Thermal resistance with an intermediate ductile layer needs to be better characterized. Presently the effect of the ductile layer on the variability of thermal resistance is not but needs to be known.

\section{COLD END HARDWARE THERMAL RESISTANCE}

A number of tests have been conducted to study the magnitude and reproducibility of the thermal resistance of the SN-1 cold hardware. These measurements were made along with the cold end interfacial $\Delta T$ measurements. All specimens were $X$-rayed before the test in order to provide some indication of bond quality. The results, which are displayed in Figure 4, show that whereas there does seem to be some correlation between bond quality and thermal resistance, it isn't strong enough to warrant using $X$-rays alone as a $Q C$ inspection tool. (This is not to say that $X$-ray couldn't be used for detecting grossly flawed assemblies). In any event, the data indicates that reproducibility of thermal resistance is not a problem.

\section{CHEMICAL COMPATIBILITY OF NICKEL HOT JUNCTION ELECTRODES WITH GdSP}

Nickel, as a $T_{H J}$ electrode for $\mathrm{GdSe}_{\mathrm{X}}$, was proposed as a substitute for the gadolinium foil being used. Unpublished postmortum findings indicated gadolinium will be completely converted to various gadolinium selenides before Galileo EOM. As a result of these findings, the following evaluation program was initiated:

Objectives:

- Study the effect of P-TPM-217 sublimation suppression on nickel hot junction electrode.

- Study the compatibility of nickel/GdSe ${ }_{x}$ under simulated module conditions. 


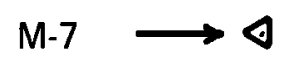

$\mathrm{M}-7 \longrightarrow \triangleleft$

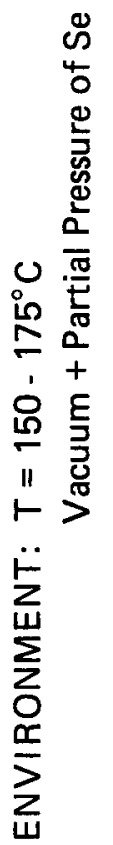

$\odot$

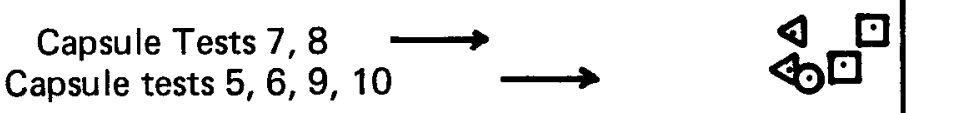

Capsule tests $9,10 \longrightarrow ه \square$

Capsule tests, 7,8 $\longrightarrow$
○

$\triangleleft \infty$

?

$$
\text { ATT } 583, M-21 \longrightarrow
$$

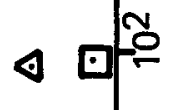

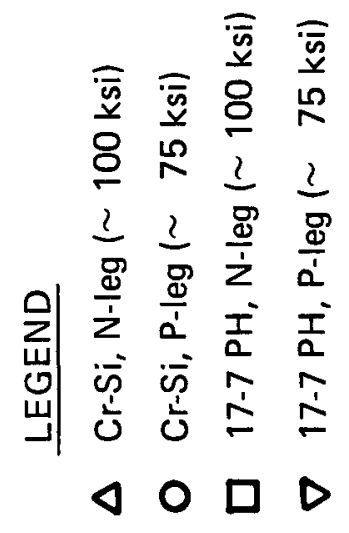

Percent Load Relaxation

8

8

ㅇ

กิ

FIGURE III-1: A COMPILATION OF LOAD RELAXATION DATA 


\section{TABLE $\| 1 \mid-1$}

\section{A COMPILATION OF LOAD RELAXATION DATA}

Material
Cr-Si
302 Stainless
$17-7$ PH (R.T. Set)
$17-7$ PH (H.T. Set)
Cr-Si
17-7 PH (R.T. Set)
Cr-Si
17-7 PH (R.T. Set)
Cr-Si
17-7 PH (R.T. Set)

\begin{tabular}{cc}
$\begin{array}{cc}\text { Corrected } \\
\text { Stress (ksi) }\end{array}$ & Temperature $\left({ }^{\circ} \mathrm{C}\right)$ \\
\cline { 2 - 2 } 100 & 150 \\
100 & 150 \\
100 & 150 \\
100 & 150 \\
73.4 & 179 \\
85.1 & 179 \\
100 & 175 \\
100 & 175 \\
100 & 175 \\
100 & 175
\end{tabular}

\begin{tabular}{|c|c|c|c|}
\hline Environment & Duration (hrs) & $\%$ Load Loss & $\begin{array}{l}\text { No. of } \\
\text { Springs }\end{array}$ \\
\hline Air & 274 & 4.6 & 6 \\
\hline Air & 274 & 5.9 & 6 \\
\hline Air & 274 & 3.1 & 6 \\
\hline Air & 274 & 2.9 & 6 \\
\hline Vacuum + Se & 283 & 8.0 & 6 \\
\hline Vacuum + Se & 283 & 7.0 & 6 \\
\hline Vacuum + Se & 360 & 8.3 & 12 \\
\hline Vacuum + Se & 360 & 3.1 & 12 \\
\hline Vacuum & 300 & 9.1 & 12 \\
\hline Vacuum & 300 & 4.3 & 12 \\
\hline
\end{tabular}




\section{TABLE |II-2}

COMPILATION OF INTERFACIAL $\triangle T$ RESULTS

\begin{tabular}{|c|c|c|c|c|c|c|c|c|}
\hline Test No. & $\begin{array}{l}\text { Segment } \\
\text { Material }\end{array}$ & $\begin{array}{l}\text { Intermediate } \\
\text { Material }\end{array}$ & $\begin{array}{l}\text { Contact } \\
\text { Pressure } \\
\text { (Psi) } \\
\end{array}$ & $\begin{array}{l}\text { Mean } \\
\text { Temperature } \\
\left({ }^{\circ} \mathrm{C}\right) \\
\end{array}$ & $\begin{array}{l}\text { Heat } \\
\text { Flux } \\
(W) \\
\end{array}$ & $\begin{array}{l}\text { Mean } \\
\triangle T \\
\left({ }^{\circ} \mathrm{C}\right) \\
\end{array}$ & $\begin{array}{l}\text { No. of } \\
\triangle T \\
\text { Readings } \\
\end{array}$ & $\begin{array}{l}\text { Contact } \\
\text { Resistance } \\
\left({ }^{\circ} \mathrm{C} / \mathrm{W}\right) \\
\end{array}$ \\
\hline 1 & 2024-T7 & None & 65.0 & 142 & 26.7 & 5.8 & 1 & .217 \\
\hline 2 & 6061-T6 & None & 65.0 & 119 & 35.4 & 7.7 & 1 & .218 \\
\hline 3 & 6061-T6 & $.001 \mathrm{Sn}$ foil & 65.0 & 236 & 32.6 & 5.2 & 3 & .160 \\
\hline 4 & 6061-T6 & None & 65.0 & 58.1 & 49.9 & 12.8 & 3 & .257 \\
\hline 5 & 6061-T6 & None & 65.0 & 47.7 & 53.8 & 19.0 & 3 & .353 \\
\hline 6 & 6061-T6 & None & 65.0 & 128 & 40.4 & 11.3 & 2 & .280 \\
\hline 7 & 6061-T6 & None & 65.0 & 133 & 41.2 & 9.3 & 1 & .226 \\
\hline 8 & 6061-T6 & None & 65.0 & 139 & 37.0 & 7.8 & 1 & .211 \\
\hline
\end{tabular}


TABLE III-3

COMPILATION OF COLD END HARDWARE THERMAL RESISTANCE DATA

\begin{tabular}{ccc} 
Assembly No. & Thermal Resistance $\left({ }^{\circ} \mathrm{C} / \mathrm{W}\right)$ & Bond Quality \\
\cline { 2 - 3 } 1 & 5.04 & Good \\
2 & 7.08 & Poor \\
3 & 7.92 & Fair \\
4 & 6.40 & Poor \\
5 & 6.42 & Good \\
6 & 6.22 & Poor
\end{tabular}


Technical Approach:

- Accelerated operation simulating module conditions (TPM-217 material lost to approximate that lost during 50,000 hours).

- Post-test evaluation to include: physical, visual and chemical techniques to measure foreign material uptake by the nickel.

Matrix:

1. Fixtures

2. T/E Materials

3. Electrodes

4. Compression Pressure

5. Atmosphere

6. Insulation

7. Temperature

8. Time

9. Current
- 12-station with module hardware.

- Copper bonded partition or non-partitioned .260" dia. TPM-217 W-Th $/ \mathrm{Ag}^{-T_{c}}$ sputtered .300" dia. GdSe . $^{\prime}$

- W-Re, TPM-217 .027" nickel pressure engaged to $\mathrm{GdSe}_{\mathrm{X}}$.

- Module specifications.

- Vacuum 10-6-10-7 torr.

- Fiberfrax $\mathrm{H}$-blanket.

- $\mathrm{T}_{h}$ as close to $900^{\circ} \mathrm{C}$ as possible.

- 160 hours ( 1 test). $>1000$ hours ( 1 test).

-5 amps.

\section{Analytical Evaluation Techniques:}

- Metallurgical.

- Visual.

- Physical - weight loss TPM-217.

- Chemical/Instrumental - (1) Trace emission spectroscopy.

(2) Qualitative microprobe.

\section{Thermodynamic Considerations:}

The following reactions were considered in the evaluation of the nickel $-\mathrm{Gd}_{2} \mathrm{Se}_{3}$ system:

1. $\mathrm{Ni}_{(\mathrm{S})}+\mathrm{Se}(\mathrm{S})$

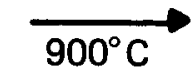

$\mathrm{NiSe}_{(\mathrm{S})}$

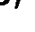$$
\begin{aligned}
& \Delta S=-2.3 \mathrm{cal} / \mathrm{mol}-\mathrm{deg} \\
& \Delta \mathrm{G}=-7.3 \mathrm{k}-\mathrm{cal} / \mathrm{mol}
\end{aligned}
$$

(2) $2 \mathrm{NiSe}(\mathrm{S})$

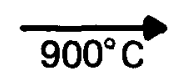

$$
2 \mathrm{Ni}_{(\mathrm{S})}+2 \mathrm{Se}(\mathrm{S})
$$

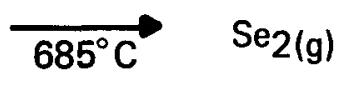

(Equation $\log _{10} P_{\text {torr }}=8.0886-$ $\frac{4989.5}{T}$ $\mathrm{T}$

$$
\Delta \mathrm{H}=-10 \mathrm{k}-\mathrm{cal} / \mathrm{mol}
$$

$$
\begin{aligned}
& \Delta H=20 \mathrm{k}-\mathrm{cal} / \mathrm{mol} \\
& \Delta S=-4.6 \mathrm{cal} / \mathrm{mol}-\mathrm{deg}
\end{aligned}
$$

$\Delta \mathrm{H}_{\mathrm{Se}} 2=22.81 \mathrm{k}-\mathrm{cal} / \mathrm{mol}$

$(S \rightarrow G)$

$\Delta \mathrm{S}_{\mathrm{Se} 2}=23.8 \mathrm{cal} / \mathrm{mol}-\mathrm{deg}(\mathrm{S} \rightarrow \mathrm{G})$

* Andier N. Nesmeyanov, Vapor Pressure of the Elements, USSR Academy of Sciences, p. 331, 1961. 

(4) $2 \mathrm{Gd}_{(\mathrm{S})}+3 \mathrm{Se}_{(\mathrm{S})} \underset{900^{\circ} \mathrm{C}}{\longrightarrow} \mathrm{Gd}_{2} \mathrm{Se}_{3}$ (S) $\Delta H=-255 \mathrm{k}-\mathrm{cal} / \mathrm{mol}$ $\Delta \mathrm{S}=-7.2 \mathrm{cal} / \mathrm{mol}-\mathrm{deg}$ $\Delta \mathrm{G}=-246 \mathrm{k}-\mathrm{cal} / \mathrm{mol}$
(5) $\mathrm{Gd}_{2} \mathrm{Se}_{3}(\mathrm{~S})+\mathrm{Ni}_{(\mathrm{S})} \underset{900^{\circ} \mathrm{C}}{\longrightarrow} \mathrm{NiSe}_{(\mathrm{S})}$

$$
\begin{aligned}
& \Delta H=27 \mathrm{k}-\mathrm{cal} / \mathrm{mol} \\
& \Delta \mathrm{S}=-12.1 \mathrm{cal} / \mathrm{mol}-\mathrm{deg}
\end{aligned}
$$$$
\Delta \mathrm{G}=38.2 \mathrm{k}-\mathrm{cal} / \mathrm{mol}
$$

Combining the data from equation 2 and 3, the partial pressure of $\mathrm{Se}_{2}(\mathrm{~g})$, over $\mathrm{NiSe}(\mathrm{S})$ at $900^{\circ} \mathrm{C}$ was found to be 0.1 torr. This value is substantially higher than previous Knudsen cell data on $\mathrm{Gd}_{2} \mathrm{Se}_{3}$ from which the partial pressure of $\mathrm{Se}_{2}(\mathrm{~g})$ over $\mathrm{Gd}_{2} \mathrm{Se}_{3}$ at $900^{\circ} \mathrm{C}$ was found to be $10^{-8}$ torr.

From the above thermodynamic consideration, the nickel- $\mathrm{Gd}_{2} \mathrm{Se}_{3}$ system is judged to be compatible.

\section{Experimental Results:}

- Black deposit of Ta-Se on Ta gimbal.

- Nickel foil free from foreign materials.

- Moly current strap as pretest.

- Ta gimbal/Ni foil/GdSe $\mathrm{G}_{\mathbf{x}}$ all bonded together.

- No nickel diffusion into $\mathrm{GdSe}_{\mathbf{x}}$.

- TPM-217 weight loss $\sim 60 \mathrm{mg}$.

- Absolute Seebeck coefficient varied accordingly:

$\begin{array}{ll}\text { Time } & \underline{\mu v} /{ }^{\circ} \mathrm{C} \\ \text { BOT } 2 \mathrm{hr} & 205 \\ 14 \mathrm{hr} & 197 \\ 50 \mathrm{hr} & 195 \\ \text { EOT } 160 \mathrm{hr} & 202\end{array}$

- Contact resistance of nickel foil $<1 \mathrm{~m} \Omega$.

\section{Conclusions:}

Based on the above experimental and thermodynamic results, nickel and $\mathrm{Gd}_{2} \mathrm{Se}_{3}$ are judged to be compatible. 
TABLE III-4

Component

1. Ta Cone Heater

2. $\mathrm{Al}_{2} \mathrm{O}_{3} /$ Moly strap

3. Ta Gimbal

4. Ni Foil

5. $\mathrm{GdSe}_{\mathrm{X}}$

6. TPM-217

\section{Observations/Results}

As pretest: No evidence of selenization nor oxidation.

As pretest: No evidence of selenization nor oxidation.

Microprobe analysis showed the uniformly distributed black deposit to be TaSe. No evidence of oxidation was detected. The gimbal was bonded to the nickel foil which was bonded to the $\mathrm{GdSe}_{\mathrm{X}}$ element.

As pretest: Microprobe analysis of the surface indicated the foil to be free of foreign material. The foil was bonded to the Ta and the GdSe ${ }_{x}$.

Metallurgical examination indicated the $\mathrm{Ni}-\mathrm{GdSe}_{\mathbf{X}}$ interface was continuous and voidfree. No evidence of nickel inclusions were detected. TPM-217 deposits were detected on the $T_{C J} 1 / 4$ of element. Trace emission spectrographic analysis indicated $<30 \mathrm{ppm}$ $\mathrm{Ni}$ in the $\mathrm{GdSe}_{\mathbf{x}}$. This value represents the lower limit of detectibility for the ES method.

Severely erroded/rilled at $\mathrm{T}_{\mathrm{HJ}}$ : weight loss $=60 \mathrm{mg}$. 


\section{E. POCO GRAPHITE ADSORPTION/DESORPTION TESTS}

Objective:

To determine the gas adsorption rates for Poco AXF-Q1 exposed to various atmosphere conditions.

Summary:

Adsorption/desorption experiments run with Poco AXF-Q1 exposed to $42 \% \mathrm{RH}$ lab air and boiling water showed identical results. For a flight converter utilizing two (2) $500 \mathrm{~g}$ Poco rings, the expected gas adsorption during assembly and subsequent gas desorption during processing would be approximately $25 \mathrm{mg}$.

\section{Experimental Results:}

The rate of gas adsorption in $42 \% \mathrm{RH}$ lab air was measured. After inital processing according to MSI 2012, the weight gain was measured in air on an analytical balance. The rate of gas adsorption in air plateaued within thirty minutes and remained constant throughout the 216 hour test duration. These data are plotted in Figure III-2. The Poco AXF-Q1 adsorbed 25 micro grams of gas/gram of Poco during this experiment.

The effect of soaking Poco AXF-Q1 in boiling distilled water on the rate of gas adsorption in $42 \%$ $\mathrm{RH}$ lab air was also studies. The sequence for this study was:

- Soak Poco from the initial gas adsorption in lab air experiment

- Air dry Poco

- Process Poco as per MSI 2012

- Measure rate of gas adsorption in $42 \% \mathrm{RH}$ lab air

The weight gain, after the soaking and air drying but prior to processing, was $123 \mu \mathrm{g} / \mathrm{g}$ Poco. This is only a five fold increase over the $42 \% \mathrm{RH}$ lab air adsorption.

As with the initial gas adsorption experiment, the rate of gas adsorption in air plateaued within thirty minutes and remained constant throughout the 216 hour test duration. The data were identical to that for the initial gas adsorption experiment. The data are shown in Figure III-2.

The data in Figure III-2 show that the adsorption/desorption cycles are reversible. In addition, these data from this study are consistent with previously published outgassing studies. ${ }^{1}$

1. C.A. Alexander, Outgassing of Space Quality Carbons and Graphite BMI-X-682, 7/12/77. 


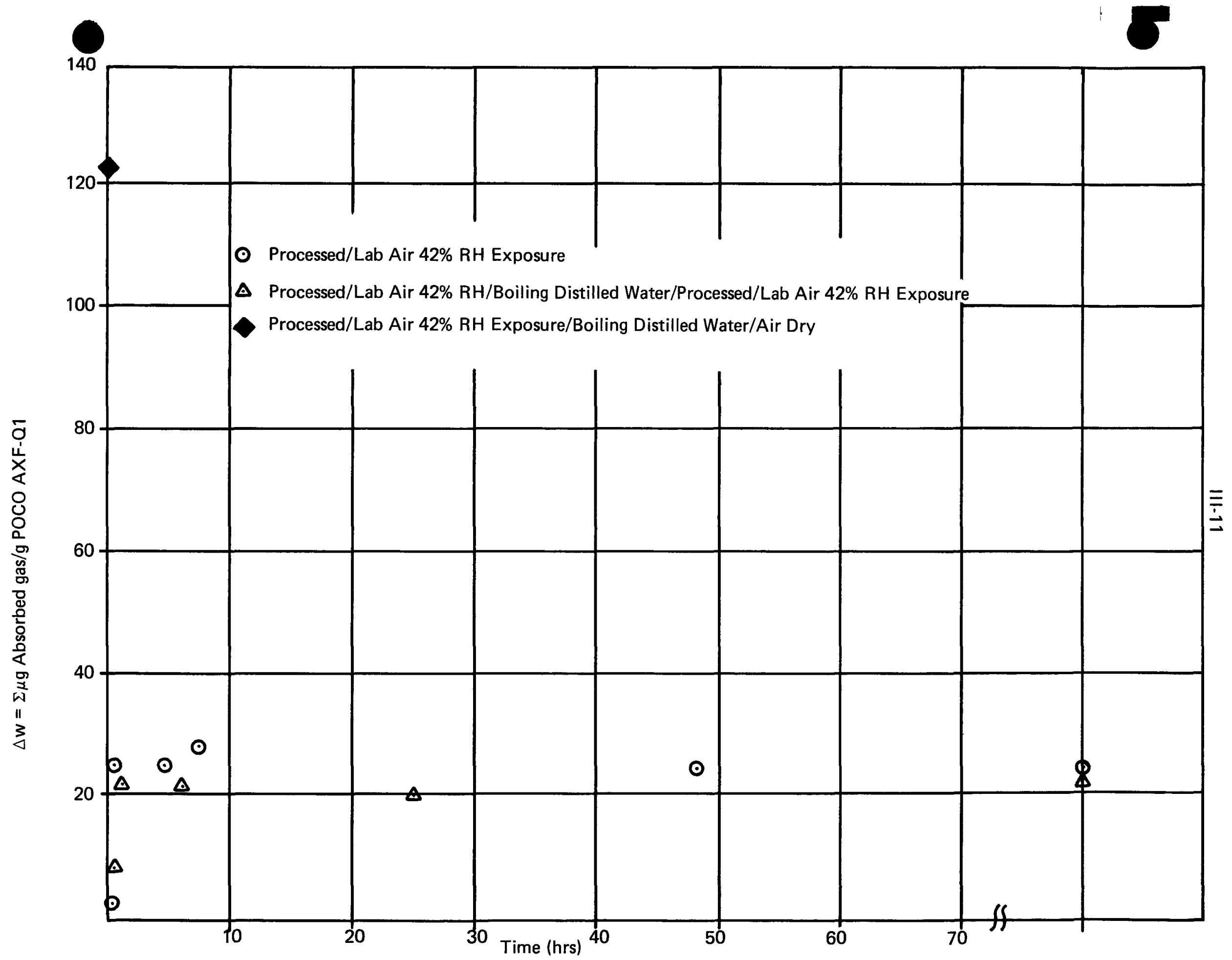

FIGURE III-2: POCO AXF-01 ADSORPTION: VARIOUS EXPOSURES 


\section{F. STORAGE CONDITIONS: SPUTTERED GdSe}

As a result of the deleterious effects of the static vacuum/water vapor environment on $\mathrm{M}-12 \mathrm{GdSe} \mathrm{x}_{\mathbf{X}}$ elements, a simple controlled experiment was initiated. Briefly this experiment involved two phases:

Phase I:

- Limiting the available water vapor $(1 \mathrm{ml})$ within a storage container under a static vacuum environment.

- Exposing two $\mathrm{Ni}$ and $\mathrm{Ag}$ sputtered $\mathrm{N}-\mathrm{GdSe}_{\mathbf{x}}$ elements plus copper foil to the above environment.

Phase 11:

- Eliminating water vapor from the same storage container.

- Exposing a $\mathrm{Ni}$ and $\mathrm{Ag}$ sputtered $\mathrm{N}-\mathrm{GdSe}_{X}$ element plus copper foil to the water vapor free static vacuum environment.

\section{Results:}

Phase I:

Within two days, both elements had started expanding and the copper foil was blackened. After a 14 day exposure, the elements and foil were completely crumbled and blackened respectively. Most likely, the available water vapor in the static vacuum environment reacted with the $\mathrm{GdSe}_{x}$ producing an oxyselenate and releasing $\mathrm{H}_{2} \mathrm{Se}$ which subsequently reacted with the copper foil.

\section{Phase 11:}

After eight-four days, the $\mathrm{GdSe}_{\mathrm{x}}$ and copper foil were as pretest with respect to:

- Weight (to $<0.5 \mathrm{mg}$ )

- Physical dimensions

- Appearance of $\mathrm{Ag}$ and Ni sputtercoats

- Appearance of foil surface

- Room temperature electrical resistance measurements

A table of the Phase II data is presented in Table III-5.

\section{Conclusions:}

Static vacuum storage of highly reactive $\mathrm{Ag}$ sputtered $\mathrm{GdSe}_{\mathbf{X}}$ is safe provided water vapor is absent.

This storage method can be accomplished in portable evacuable containers containing activated molecular sieves. 
III-13

TABLE $\| 11-5$

$\mathrm{N}-\mathrm{GdSe}_{\mathbf{x}}$

Pre-Test

Weight (g)

Physical Dimensions

Appearance

Room Temp. Electrical

Resistance

1) Total $\mathrm{m} \Omega$ as is

2) Total $\mathrm{m} \Omega$ deflashed

3) Contact $\mathrm{Nim} \Omega$ as is

4) Contact $\mathrm{Ni} \mathrm{m} \Omega$ deflashed

5) Contact $\mathrm{Ag} \mathrm{m} \Omega$ as is

6) Contact Ag $\mathrm{m} \Omega$ deflashed
2.79356

$0.305 L ; 0.315 D$

Shiny and clean

$9.99 \operatorname{lot} \bar{X}$

- -

3.22 lot $\bar{x}$

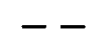

0.46

$--$
Post-Test

2.79360

$0.305 L ; 0.315 D$

Shiny and clean

Foil:

Weight (gm)

2.380

Appearance

2.378

9.3

8.1

1.85

1.35

0.19

0.22

Shiny and clean 


\section{G. TESTING TO OBTAIN RELIABILITY DATA BASE}

It was recognized that available data accumulated on selenide thermoelectric materials had limited applicability for predicting EOM power characteristics of the flight RTG for the Galileo Mission. This observation was valid because a reference design had not been selected to allow reliability testing; hence, no valid reliability data base existed. The lack of an acceptable data base coupled with the time restriction after a thermoelectric design baseline was selected mandated a form of accelerated testing.

The demonstration test program was to be formulated in two (2) phases. The accelerated test phase consisted of ten (10) 18-couple modules which were to be used to establish a relationship between acceleration factor and test conditions - the first phase. A designed experiment to determine empirically the rate of power degradation with varying stress levels of module hot and cold end temperatures and current was prepared and a summary description follows as Attachment 13. From the results of this first phase of testing, a simple polynominal equation of the following form

$$
\begin{array}{ll}
d P / d t=B_{o}+B_{1} T_{h}+B_{2} T_{c}+B_{3}^{\prime} L & \text { (first order terms) } \\
+B_{12} T_{h} T_{c}+B_{13} T_{h}^{\prime} L+B_{23} T_{c}^{\prime} L & \text { (two factor interaction terms) } \\
+B_{11} T_{h}^{2}+B_{22} T_{c}{ }^{2}+B_{33} L^{2} & \text { (second order terms) } \\
+B_{123} T_{h} T_{C}^{\prime} L & \text { (three factor interaction term) }
\end{array}
$$

would be generated using least squares multiple non-linear regression techniques. Also a theoretical investigation would be made after post test analysis of the test modules to determine why the response was affected and to construct a basic mechanistic model and an estimation of the parameter of this model. The expression for the mechanistic model would be of the form:

$$
W=\left[N_{0}\left(T_{C}\right)+b I_{L}\right]^{4} e^{-B / T_{h}}
$$

while $W$ represents loss in the $P$-leg due to sublimation effects

$$
\begin{aligned}
& N, b \text { and } B=\text { parameters } \\
& e=\text { base of the natural log }
\end{aligned}
$$

Both of these formulas would be used to establish a relationship between the desired acceleration factor of 12 for time vs. power degradation.

The second or reliability phase of the test program would consist of eight (8) eighteen-couple modules operated at an acceleration factor of twelve to verify performance over the 50,000 hour space mission in about 4,000 hours. In both phases the eighteen-couple modules would be fully instrumented as three (3) quasi-independent six-couple modules, i.e., six-couple current, open and closed circuit voltages as well as individual leg hot and cold end temperatures and voltages were to be monitored. 
Computer programs were prepared to enable the data acquisition system to collect data on a programmed time interval basis for storage in the data collection system. Programs to print out parametric data on command from reduction of the stored raw data were also prepared.

The assumption was made that other potential failure mechanisms such as (1) long term effect of $\mathrm{N}$-leg element cracking, (2) reduction of element contact pressure due to spring relaxation, (3) loss of sublimation wrap seal of P-legs, and (4) selenium deposition and chemical attack on the other module materials would be resolved by the time of the design freeze.

Satisfactory operation of the twenty-four (24) quasi-independent six-couple modules at the $12 x$ acceleration factor would demonstrate 0.95 reliability at $70 \%$ confidence level on an attributes basis for the time frame of the test. 


\section{$|I|-16$}

ATTACHMENT TO SECTION III 


\title{
ATTACHMENT 13
}

\author{
Testing to Obtain Reliability Data Base
}

A description of a designed experiment to determine empirically the rate of power degradation with varying stress levels of hot and cold end temperatures and current and maximize the information for data reduction was prepared. This description follows.

To adequately describe the degradation empirically it was recommended that a test matrix be utilized that would include not only variation in $T_{h}$ but also in independent variables $T_{c}$, cold end temperature, and $I_{L}$, load current. The object of such a test program would be to get better definition of output power changes with excursions in these independent variables.

The informational data available from such a series of tests will make SIG/Galileo power prediction procedures more accurate since it is possible that $T_{h}, T_{c}$ and $I_{L}$ may vary outside the design limits over the mission time frame. Such excursions in hot and cold end temperatures and current can occur because of the following considerations:

1) Fuel Decay.

2) Insulation degradation.

3) Heat pipe performance degradation.

4) Emissive coating degradation.

5) Solar and planetary IR fluxes variation.

6) SIG/RTG vehicle orientation.

7) Degradation of conductivity in one of the leg current paths could lead to increased current in the parellel leg.

A review of the best procedures for a designed experiment to achieve the maximum information and efficiency of observations for most meaningful data analysis was made.

Some of the considerations involved in design of experiments are briefly summarized in the following paragraphs.

A planned designed experiment should incorporate the following basic concepts: randomization, replication and orthogonality.

Randomization in a design means to conduct the order of experimental runs in a random (not systematic) fashion. Randomization of test order eliminates or balances out the effects of extraneous or undesirable systematic variation. The effect of such randomization is to make it legitimate to analyze the results as if they were independent.

Replication is the repetition of an experimental run. In the analysis of experimental results it is important to have an estimate of experimental error (i.e., random error). To replicate requires the preparation of two or more independent samples treated as nearly alike as possible. It is common practice to obtain an estimate of the experimental error variance when only quantitative variables are involved by replicating the center point of the design. This is accomplished by setting the variables at their center levels and making several independent observations at these settings. These center points are worked into the random order of performing the entire experiment. 
Orthogonality in a design implies that the estimates of the main effects and interactions are uncorrelated with each other. Designs having this property insure that if a systematic change occurs corresponding to any one of the effects, the change will be associated with that effect alone.

\section{Factorial Experimental Designs}

Factorial experiment designs are superior to one factor at a time experimentation in many respects.

1. The effects of several factors in the same set of experiments can be studied simultaneously.

2. The effect of each factor at all levels of the other factors can be tested and whether or not this effect changes as other factors change.

3. Tests can be made for the effects of the factors separately (the main effects) and also for joint effects of two or more factors combined (interaction effects).

4. It is possible to obtain a more complete picture of what is happening over the entire "experimental region of interest" than would be obtained by varying each of the factors one at a time while keeping the others constant.

5. Every judgement made about the effects of the factors is based on all the observations accumulated in the entire set of experiments, not merely on a few selected observations. Thus, factorial experiments are more sensitive in the detection of small effects.

\section{Scaling Coding of the Independent Variables}

It is very desirable to "standardize" or "code" the levels of the independent variables. The coded variables are often much easier to manipulate, analyze and interpret than the original variables. When

the factor is continuous such as temperature or current, a suitable coding procedure can be imposed on the original levels of the factor and refer to the levels as the high level $a+1$ and the low level as -1 . The midpoint or center point is 0 .

\section{Rotatability}

For a rotatable design, the variance of the estimated response is constant at a given distance in any direction from the origin (center) of the design in the $\mathrm{K}$ - dimensional factor space defined by the independent variables. For $k=3$ the $\propto$ value for rotatability is $2^{3 / 4}=1.682$.

Investigation of the response function include empirical studies aimes at how the controlled variable affect the response by means of simple polynominal equations of the following form:

Response (change in power as a function of time)

$=$ Bo (constant term)

$$
\begin{aligned}
& +B_{1} T_{h}+B_{2} T_{C}+B_{3} I_{L} \quad \text { (first order terms) } \\
& +B_{12} T_{h} T_{C}+B_{13} T_{h} I_{L}+B_{23} T_{C} I_{L} \text { (two factor interaction terms) } \\
& +B_{11} T_{h}{ }^{2}+B_{22} T_{C}{ }^{2}+B_{33} L_{L}{ }^{2} \quad \text { (second order terms) } \\
& +B_{123} T_{h} T_{C} I_{L} \quad \text { (three factor interaction term) }
\end{aligned}
$$


Also a theoretical investigation will be made to determine why the response is affected and the construction of a basic mechanistic model and the estimation of the parameters in the model. A proposed model is as follows:

$$
W=\left(N_{0}\left(T_{C}\right)+b I_{L}\right)^{4} e-B / T_{h}
$$

where $W$ represents loss in the P-leg due to sublimation effects

$$
\begin{aligned}
& N_{O}, b, B b \text { - parameters } \\
& E \text { - base of natural log. }
\end{aligned}
$$

In order to determine these coefficients for $T_{h}, T_{c}$ and $I_{L}$ through analysis of variance (ANOVA) techniques, it is recommended that a central composite second order design constructed from three main pieces, each of which comprise a set of points be used.

1) The $2^{k}$ vertices of a $k$ - dimensional "cube" or factorial design.

2) The $2 \mathrm{k}$ vertices of a $\mathrm{k}$ - dimensional "star" including.

3) A number, $N_{0}$, of "center points."

No. of Variables (factors)

K

\section{3}

No. of parameters to be estimated $(K \pm 1)(k+2) / 2$

for a full second order design

No. of runs (ecluding No.)

$$
2^{k}+2 k
$$

No. of center points

Recommended No. of runs

Actual No. of runs for proposed design

\section{Composite Design for $k=3$ Variables}
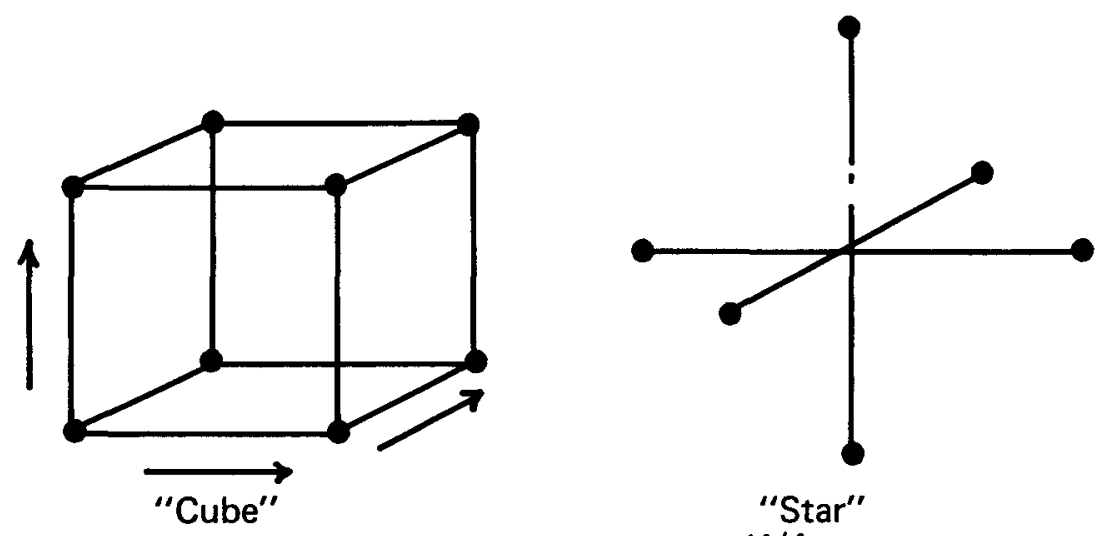

$$
\propto=2^{K / 4}=1.682
$$

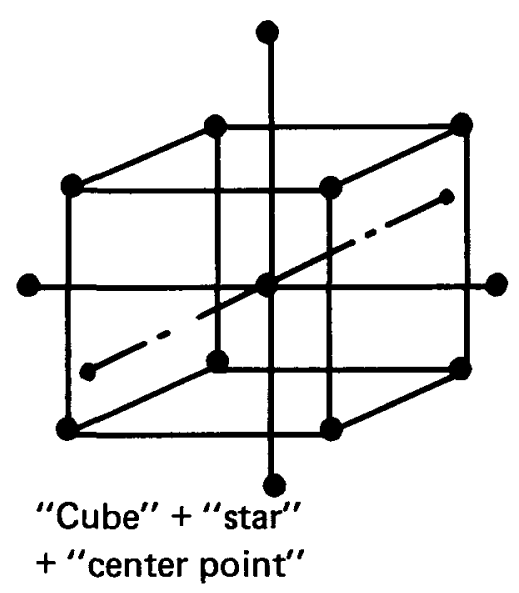

FIGURE 13-1 
Based on the above considerations, it was recommended that in addition to the five accelerated test modules M-25 to M-29 initially in the program an additional identical series of five-eighteen couple modules having flight system hardware configuration would have to have been added to the program to expand the reliability data base. These ten eighteen couple modules would each be connected electrically as three six couple sets to permit variation in current loading. The physical constraints of the eighteen couple hardware arrangement would require that $T_{h}$ and $T_{c}$ operate at a fixed temperature for a given module. The range of operating conditions would be as shown in Table 13-1.

TABLE 13-1

$\begin{array}{lccccccc}\text { Symbol } & \text { Description } & \text { Range } & -\alpha & -1 & 0 & +1 & +\propto \\ T_{h} & \text { Hot End Temp. } & 800-976^{\circ} \mathrm{C} & 800 & 836 & 888 & 940 & 976 \\ \mathrm{~T}_{\mathrm{c}} & \text { Cold End Temp. } & 125-175^{\circ} \mathrm{C} & 125 & 135 & 150 & 165 & 175 \\ \mathrm{I} & \text { Load Current } & 6.25-15.35 & 6.25 & 8.1 & 10.8 & 13.5 & 15.35\end{array}$

The lower limit for the range of hot end temperature, $T_{h}$, is selected as $800^{\circ} \mathrm{C}$ in order to increase the scope of the reliability data base and for projection of longer converter life at a lower hot end temperature. The upper limit for the hot end temperature is chosen as $976^{\circ} \mathrm{C}$ as the limit for temperature under which degradation processes will remain the same as at lower temperatures even though proceeding at an accelerated rate.

The cold end temperature, $T_{C}$, range is chosen to increase the reliability data base. The current range is based on a lower limit of possible $\Delta T$ operation of $650^{\circ} \mathrm{C}$ and an upper limit of twice rated current at $\mathbf{2 3 0}$ watts of power at 30 volts.

Figure 13-2 shows the proposed composite design in representative visual form.

All ten eighteen-couple modules will be fully instrumented as three quasi-independent six-couple modules i.e., six couple current, open and closed circuit voltages as well as individual leg hot and cold end temperatures and voltages will be monitored. The data will be collected on a programmed time interval basis and stored in the data acquisition system. The parametric data as summarized will be available on a command printout basis.

Post test analysis of the modules subjected to the accelerated stress levels of the test matrix will add information to enhance the development of a given parameter versus probability as a function of various environment conditions. Least squares regression analysis techniques may be applied as applicable to the variables data to determine trend analysis.

Results of the analyses and test of each component may be collected and integrated into a single assessment report. The assessment report will identify failure modes, experience with failures and will aid in prediction of converter performance to end-of-mission time. 


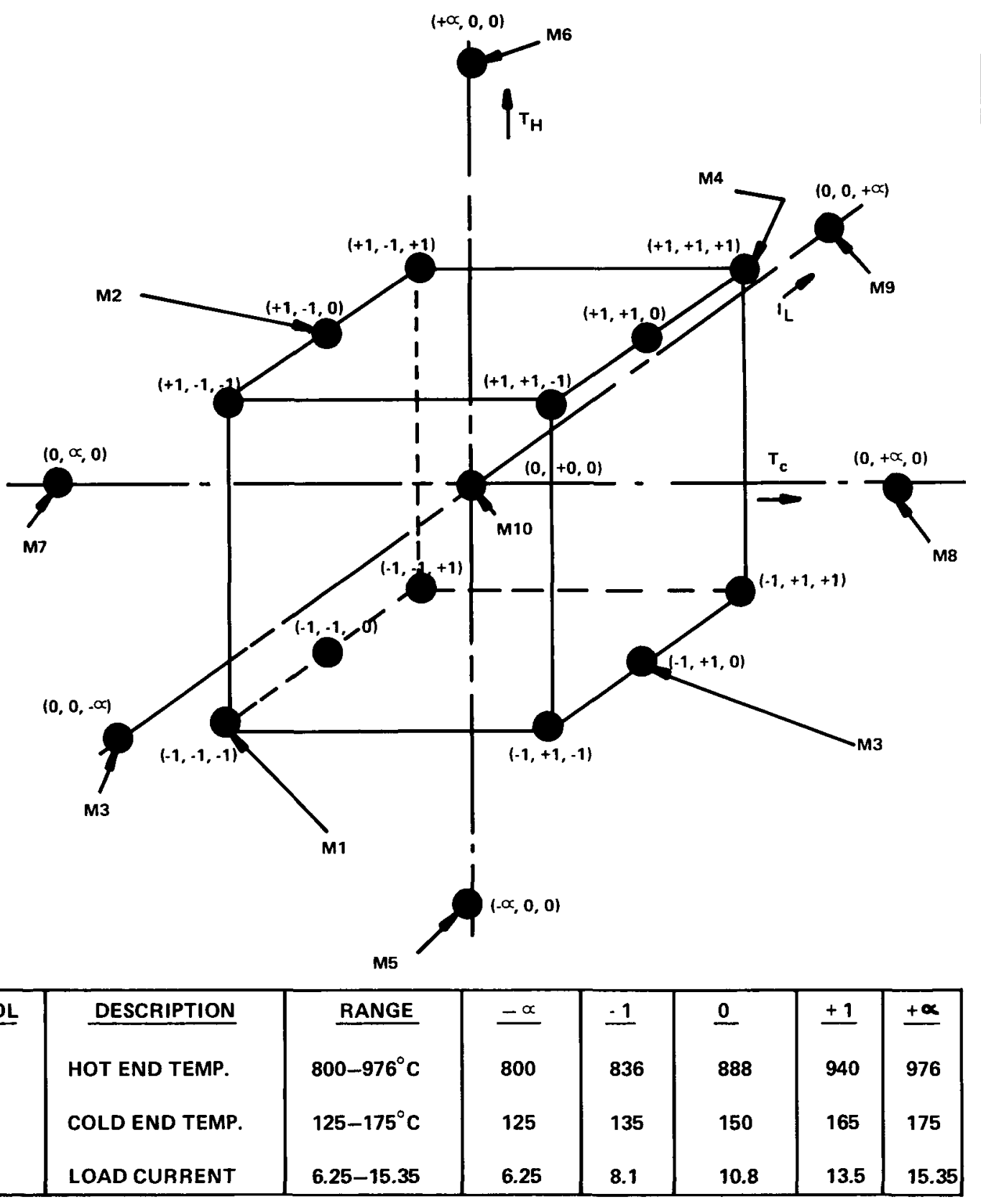

\begin{tabular}{|c|c|c|c|c|c|c|}
\hline \multicolumn{2}{|c|}{ TEST NO. } & $\begin{array}{l}\text { MATRIX } \\
\text { MODULE }\end{array}$ & $\begin{array}{l}\text { PROGRAM } \\
\text { MODULE }\end{array}$ & $T_{h}$ & $T_{c}$ & $I_{L}$ \\
\hline \multicolumn{2}{|l|}{1} & $M-1-1$ & M25A-1 & $\cdot 1$ & .1 & .1 \\
\hline \multicolumn{2}{|l|}{2} & $M-2-1$ & M25B-1 & +1 & .1 & -1 \\
\hline \multicolumn{2}{|l|}{3} & M-3-1 & M26A-1 & -1 & +1 & -1 \\
\hline \multicolumn{2}{|c|}{$42^{3}$} & $M-4-1$ & M26B-1 & +1 & +1 & -1 \\
\hline \multicolumn{2}{|c|}{5 FACTO. } & $M-1-2$ & M25A-2 & -1 & -1 & +1 \\
\hline \multicolumn{2}{|c|}{$6 \quad$ RIAL } & $M-2-2$ & M25B-2 & +1 & .1 & +1 \\
\hline \multicolumn{2}{|l|}{7} & $M-3-2$ & M26A-2 & -1 & +1 & +1 \\
\hline \multicolumn{2}{|l|}{8} & $M-4-2$ & M26B-2 & +1 & +1 & +1 \\
\hline \multicolumn{2}{|l|}{9} & $M-1-3$ & M25A-1 & -1 & .1 & 0 \\
\hline 10 & $I_{L}$ & $M-2-3$ & M25B-3 & +1 & -1 & 0 \\
\hline \multirow[t]{2}{*}{11} & CENTER & $M-3-3$ & M25A-3 & -1 & +1 & 0 \\
\hline & POINTS & & & & & \\
\hline \multicolumn{2}{|l|}{12} & $M-4-3$ & M268-3 & +1 & +1 & 0 \\
\hline \multicolumn{2}{|l|}{13} & $M-5-1$ & M27A-1 & $-\infty$ & 0 & 0 \\
\hline 14 & $\propto$ & M-6-1 & M27B-1 & $+\propto$ & 0 & 0 \\
\hline 15 & POINTS & $M-7-1$ & M28A-1 & 0 & $-\alpha$ & 0 \\
\hline 16 & FOR 2ND & $M-8-1$ & M28B-1 & 0 & $+\alpha$ & 0 \\
\hline 17 & ORDER & $M-9-1$ & M29A-1 & 0 & 0 & $-\propto$ \\
\hline 18 & EFFECTS & $M-9-2$ & M29A2 & 0 & o & $+\infty$ \\
\hline 19 & & $M-9-3$ & M29A-3 & 0 & 0 & 0 \\
\hline 20 & MATRIX & M-10-1 & M29B-1 & 0 & 0 & 0 \\
\hline 21 & CENTER & $M-10-2$ & M29B-2 & 0 & 0 & 0 \\
\hline 22 & POINTS & M-10-3 & M29B-3 & 0 & 0 & 0 \\
\hline 23 & & $M-5-2$ & M27A-2 & $-\propto$ & 0 & 0 \\
\hline 24 & & $M-5-3$ & M27A-3 & $-\propto$ & 0 & 0 \\
\hline 25 & & $M-6-2$ & M27B-2 & $+\infty$ & 0 & 0 \\
\hline 26 & REPLI- & $M-6-3$ & M27B-3 & $+\infty$ & 0 & 0 \\
\hline 27 & CATE & $M-7-2$ & M28A-2 & 0 & $-\alpha$ & 0 \\
\hline 28 & POINTS & $M-7-3$ & M28A-3 & 0 & $-\propto$ & 0 \\
\hline 29 & & $M-8-2$ & M28B-2 & 0 & $+\propto$ & 0 \\
\hline 30 & & $M-8-3$ & M28B-3 & 0 & $+\propto$ & 0 \\
\hline
\end{tabular}

FIGURE 13-2: TEST MATRIX 


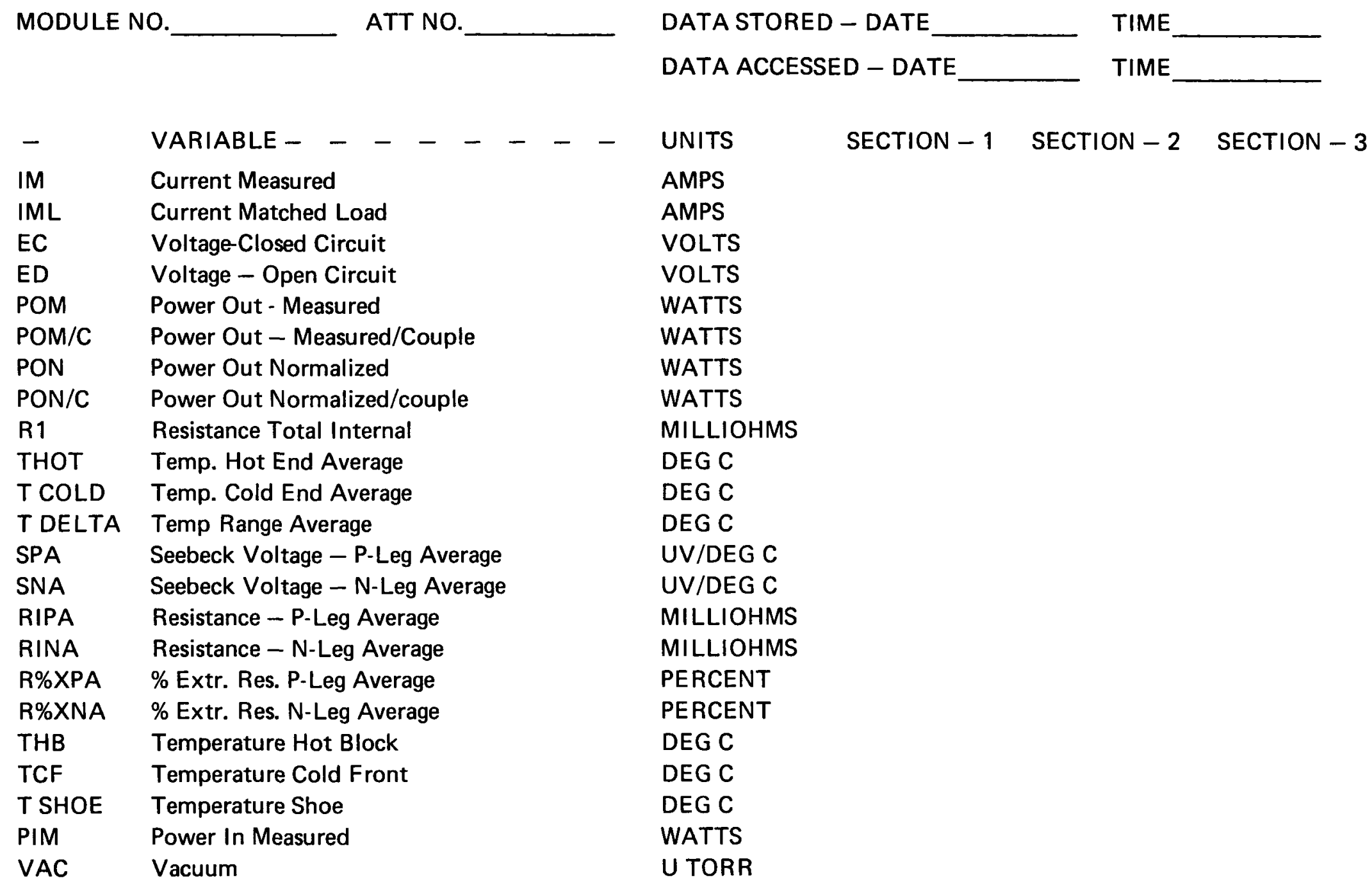




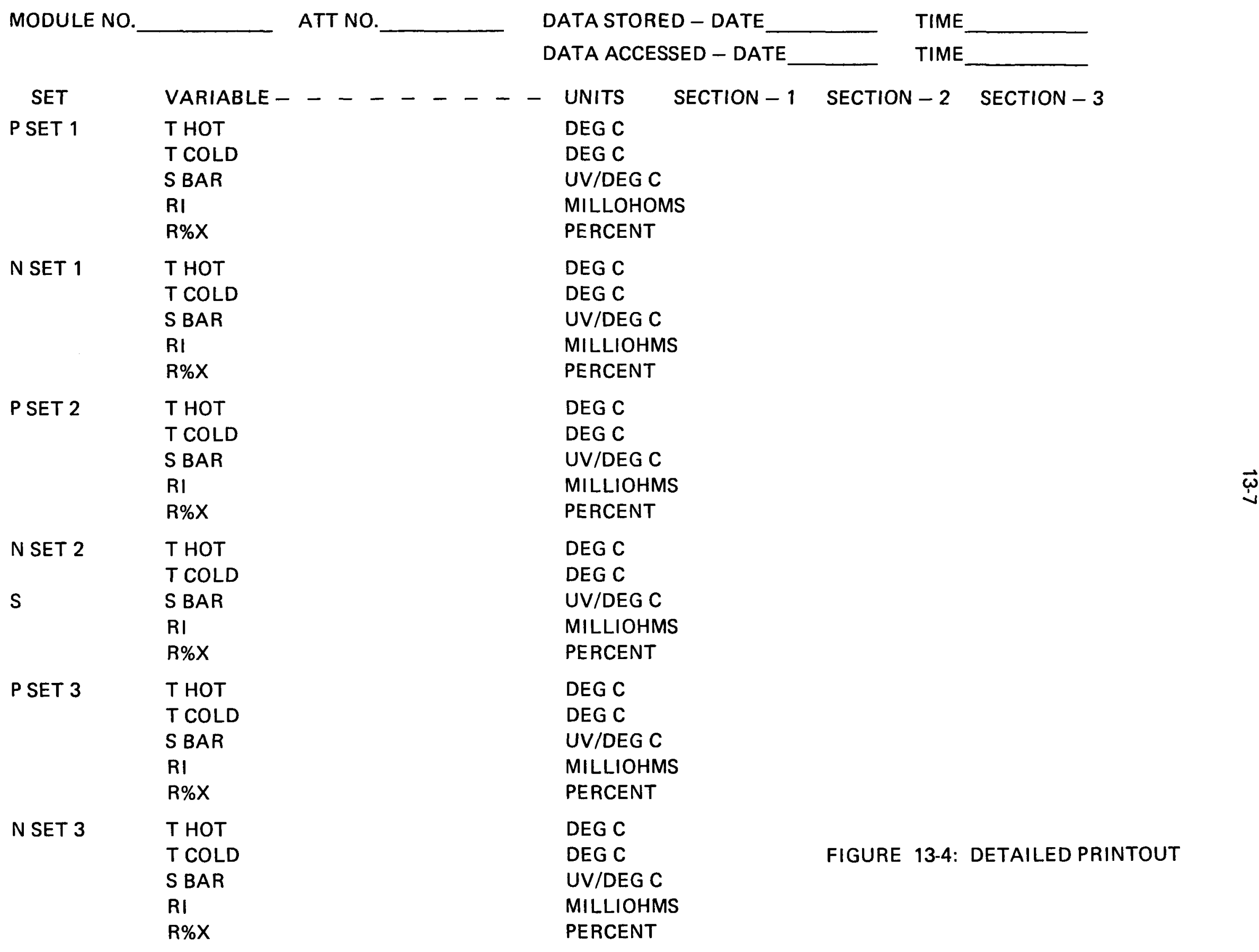




\section{MANUFACTURING}

The manufacturing objectives at the start of the Galileo Program were to build seven (7) SN converters consisting of two (2) rings of 168-couples in each ring and sixteen (16) test modules of 18-couples each. This was to be done over a period of approximately thirty-six (36) months.

Planning and scheduling were started utilizing designs and experience from the Technology Program as the base line. CRAM (Critical Resources Allocation Method), a form of network analysis for scheduling manufacturing of $\mathrm{SN}-1$ was instituted during this program.

Make and buy decisions and vendor selection were based on prior development of the hardware during the Technology Program. During the planning stage, the long lead time items were identified so that the raw materials or unfinished goods could be identified. It was also planned that materials would be certified where ever possible in this program.

\section{A. HOT FRAME AND HEATER BLOCKS}

The material used is a high purity, high density graphite supplied by POCO, identified as POCO AFX-01. This material was specified for Galileo; it had been used in modules and GDS-I. This is a single source item. Experience in the past and discussions with POCO indicate that delivery of three (3) or more size $8-1 / 4^{\prime \prime} \times 8-1 / 4^{\prime \prime} \times 3-1 / 4^{\prime \prime}$ graphite blocks of the quality required might take a year. This is the largest size in width (8-1/4") that can be produced by their equipment. Apparently the yield rate for graphite blocks of the size and quality needed for Galileo is quite low, and the elapsed time to process such blocks is sixteen (16) to twenty (20) weeks.

Experience has shown that as much as three (3) runs have been required to obtain blocks of the required size and quality. Approval was granted to start early procurement of graphite blocks. POCO was to machine two (2) rings from two (2) blocks for SN-1. Due to schedule considerations and providing for a second machining source of graphite, a local vendor machined two (2) rings for SN-2 or back-up for SN-1 if needed, because of schedule or damage. Ultrasonic scan charts for eight (8) graphite blocks, SN-3, SN-4, SN-5 and SN-6, were delivered to 3M for review. They were found acceptable by QC, but further work was held due to Galileo stop work order. Some of these blocks are or will be used for heater blocks for modules in the Technology Program. Larger blocks are required because of the use of larger diameter heaters in the Technology Program. Prior to final assembly, the graphite goes through a cleaning process which includes a high temperature vacuum bakeout procedure.

\section{B. CERAMIC PINS}

The ceramic pins used to locate the P-legs on the hot straps were made of alumina rod cut to length.

\section{Platinum Strips}

Platinum strips .0005" thick and die cut to provide holes under the $\mathrm{N}$-leg gimbal and match the outside contour of the hot current straps were designed. There was a minor problem trying to develop a die to cut .0005" thick platinum without tearing or burring. This had apparently been solved when the stop work order was received. 


\section{HOT CURRENT STRAPS - GIMBALS}

The hot current straps were machined from molybdenum sheets. The gimbals are machined from molybdenum then finish machined to match the hot straps. The set is identified and marked. The hot straps are then sent to St. Louis, MO, for alumina plasma spray coating on the bottom surface which contacts the platinum and graphite. Some time and effort was spent with various potential suppliers in selecting a vendor. Additional effort was spent to develop a corner treatment chamfer/ radius so that the spray coating would bond to the lower corner and bond for some distance up the sides to reduce cracking and chipping. Coating on the corners and sides would reduce the potential for shorts caused by platinum touching the bare molybdenum. If small conductive particles touched the graphite or platinum and the bare hot straps, shorts could also result. By spray coating up the sides approximately $.015^{\prime \prime}$ or more, this could reduce a potential problem. After spray coating, the alumina is finish ground to flatness and dimension. The bare top surface is also cleaned or sanded with fine grit polishing cloth or paper to remove oxides and over spray from the spraying and grinding steps. This provides a clean, flat contact surface for the legs. Prior to final assembly, the parts go through an ultrasonic solvent cleaning process.

\section{E. PLATINUM AND NICKEL FOIL DISCS}

Platinum foil .0005 thick and nickel foil .005 thick was procured. The discs could be stamped out in house or by one of several local stamping houses specializing in small precision parts. The parts were cleaned in an ultrasonic solvent cleaner.

\section{F. SUPPORT OF LEG MANUFACTURE}

\section{Gadolinium}

A study and planning exercise was undertaken with various responsible people to determine needs and schedules for specific amounts of gadolinium foil and pellets. Yield rates based on GDS-I, quantity of units to be built for testing and shipping, dates units were to be on test or shipped, all entered into the gadolinium schedule and quantity requirements list.

No gadolinium foil was shipped to $3 \mathrm{M}$ from Ames Lab, as the design was changed and gadolinium foil eliminated.

The following quantity of gadolinum pellets was received from Ames Laboratory:

\begin{tabular}{|c|c|}
\hline July 10, 1978 & 460 grams \\
\hline August 29, 1978 & 2167 grams \\
\hline October 10,1978 & 1105 grams \\
\hline November 21, 1978 & 1288 grams \\
\hline December 13, 1978 & 2433 grams \\
\hline January 30, 1979 & 2059 grams \\
\hline & 9512 grams \\
\hline
\end{tabular}

The stop work order was issued for the Galileo Program and Ames Lab made no more gadolinium pellet shipments for the Galileo Program. 
2. Tungsten $25 \%$ Rhenium Alloy for P-Leg Hot End Cap

In the technology development phase, a Tungsten 25\% Rhenium alloy .002 thick foil was used on the P-leg hot end. As testing progressed, data collected indicated that some sort of barrier would be needed on the P-leg. An astro quartz slurry wrap was tried. It became apparent that the wrap should go beyond the end of the P-leg material so that subsequent shrinkage would not leave a gap at the leg material Tungsten-25\% Rhenium foil cap interface. A proposed design was a .020" thick cap with a shoulder; the minor diameter to be .010" to .015 " thick and the major or flange diameter to be .005 to .010 thick. The minor diameter to be the same diameter as the P-leg material element. The major diameter to be $.320^{\prime \prime}$ or approximately $.025^{\prime \prime}$ on the side for the wrap to butt against. The cap would also have a blind hole .005" to .010" deep for location over the ceramic pin. Various attempts were made to produce such a cap. Obtaining .020" thick material in sufficient quantity was a problem.

Making the caps from rods was very time consuming, costly and resulted in a low yield. It did give some pieces for the first cut tests. Powder metallurgy, because of the small total requirements, did not appear a feasible solution in the opinion of some powder metallurgy houses. They mentioned the development and engineering time and costs plus tooling. $A$ purchase order was issued to Rhenium Alloys of Cleveland, $\mathrm{OH}$, to make a small number, 50 to 200 , by whatever method they deemed suitable. After about six months, they were able to make about fifty, which appeared to be usable for testing.

A few square inches of .020" thick sheet was obtained. This was given to a local supplier, who tried various machining techniques. We were able to order .020" thick foil from H. Cross and Schwartzkopf. We obtained some material but there were delays in delivery. We attempted to find other sources of Tungsten $25 \%$ Rhenium, contacting DoE, ORNL, Sandia and various other agencies. We contacted ThermoElectron who had a small amount and would try to make caps for us. They were able to develop a process after about eight weeks that would yield about fifty caps each week. Due to the Galileo stop work order, our purchase order with Thermo-Electron was cancelled.

Knight Tool, a local supplier, was able to develop a method of making caps at about 200 a week. Some of the foil received was pure Tungsten. It shattered when punched and did not pass electrical conductivity screening tests. It was returned and the supplier replaced it as soon as he could in partial shipments. The method that made acceptable parts at the least cost and largest weekly quantity delivery required punching discs, EDM (Electro Discharge Machining) the flange and the blind locating hole.

\section{G. COLD END HARDWARE - SUB-ASSEMBLY COLD FRAME SEGMENTS}

The cold frame segments are made of 6061-T6 Aluminum. Aluminum plate 4" thick and multiples of $12^{\prime \prime}$ in length and width are the basic starting material. The plate is cut into 12 inch square sections. The center is cut out and the corners are cut off, leaving a rough ring. The ring is machined on a numerical controlled mill; then cut up into segments. Some study was given to making the

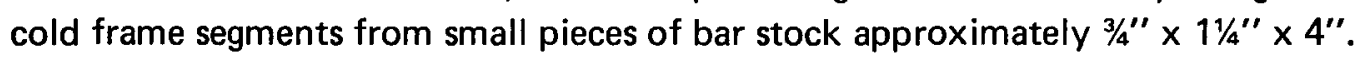


The cold frame segments for $\mathrm{SN}-1$ and $\mathrm{SN}-2$ were machined from a large plate by numerical control tape milling machines. The segments were electroless nickel plated in order to provide a surface for soldering the copper flexible follower. Another benefit of the electroless nickel plate is burr reduction; the plating process etches and smooths the fine burrs, rounds/breaks sharp corners. It also provides a surface which reduces the potential for twist locks to turn up chips and burrs when installed.

\section{H. TWIST LOCKS}

The twist locks are machined from 6061-T6 Aluminum bar stock, slotted and sides trimmed in a press. The twist locks are electroless nickel plated to reduce burr and/or chip generation from the spring end or the edge of the retainer step of the cold frame segment.

\section{COLD FRAME SEGMENT}

Work was being done in attempting to tin plate the base of the cold frame segment which is in contact with the finned housing. At the time of the stop work order, no parts had been tin plated meeting a design objective or an acceptable level. The alternative method was to use tin foil which was intended to be used in $\mathrm{SN}-1$.

\section{J. COPPER FOIL FLEXIBLE FOLLOWERS/COLD CURRENT STRAPS}

The SN-1 design flexible follower was made up of fourteen (14) layers of .0015 thick ETP copper foil (CDA 110).

A copper foil sheet is photo etched or chemically milled so that the excess copper is removed, leaving a chain of seven (7) pieces attached to each other by small tabs. The chain is then accordion folded, using a fixture to locate the holes or outer edges, resulting in one (1) piece seven (7) layers thick. The ends of the seven (7) layer folded part are spot welded with one (1) small spot in order to maintain alignment during the bonding assembly. During the development of this part, it was found that in trying to spot weld the large required areas, the spot welds were of poor quality, generally burr holes and pits in the spot welded area. The seven (7) layer parts or in the case of the flexible follower, two (2) seven (7) layer stacks are placed in a bonding fixture in an inert atmosphere (Argon). The fixture is heated and pressure applied which results in the part being bonded to two (2), three (3) or four (4) places, depending on the part design. The areas not bonded are flexible and each leaf or layer can be flexed which makes the part more flexible than if it were one (1) piece the same thickness. The same process is used to make cold current straps. The flexible followers are fourteen (14) layers thick and two (2) seven (7) layer stacks used. The cold current straps are seven (7) layers thick and one (1) seven (7) layer stack is used. The tabs used in folding the layers are trimmed away after bonding. It is important that the copper parts be clean, and be kept clean after the photo etch or chemical milling process so as not to become oxidized. It is also important that in the bonding process, especially when heating up, that there be no oxygen present. Use of inert gas or vacuum is required. Oxides on the copper affect bonding quality, strength and the area of bond. 
The copper foil bonding operation was developed and bench tested in the lab. Acceptable parts were made for tests and modules. The operation was scaled up primarily through the use of several sets of tooling, moved and set up in a short run production facility. The operation was set up, with test and pilot runs being made, but had not gone into full scale production when the Galileo stop work order was issued. This operation has since been dismantled and the equipment returned to the lab.

\section{K. SPRING RETAINER BUTTONS}

The spring retainer buttons are made of ETP copper bar stock on a lathe. The function of this part is to locate the cold current strap end of the Helical coil spring.

\section{BeO DISCS}

The beryllium oxide discs act as an electrical insulator, but a thermal conductor in the cold end sub-assembly.

These parts are a long lead time item and promised delivery dates are not always kept, nor do the suppliers always meet all specifications. For these reasons, purchase orders were placed with several suppliers. At the time of the order, it was not known what type of solder or braze material was to be used; the discs were specified only with molybdenum mangenese coating with nickel plating on both sides.

The coating was specified so that at least a .007" wide band at the circumference would not be coated. This was to prevent solder from running to the edge of the beryllium oxide disc.

Some of the $\mathrm{BeO}$ discs were dished so they would not bond properly to the cold current straps or copper spring retainer buttons with the specified amount of solder.

\section{COLD CURRENT STRAP SUB-ASSEMBLY}

All the parts were cleaned ultrasonically in Freon solvent. Solder preforms made from .0015 thick solder ribbon are used on each side of the $\mathrm{BeO}$ disc. The Molybdenum-Manganese coated area is fluxed with a minute drop of flux on each side. The parts are loaded into a solder fixture. The cold current strap is placed in position with the solder preform then the fluxed $\mathrm{BeO}$ disc is loaded with the copper spring retainer. The fixture is placed into a quartz tube in a tube furnace hooked up to a vacuum system, pumped down and heated up. When the piece parts reach the prescribed temperature, the heat is turned off, the quartz tube removed from the furnace and allowed to cool with the vacuum system operating.

\section{N. COLD FRAME SEGMENT AND FLEXIBLE FOLLOWER SOLDER SUB-ASSEMBLY}

The cold frame segment and copper foil followers are cleaned ultrasonically with Freon solvent. The cold frame segment with electroless nickel plate is fluxed, a solder preform is placed on the rail then the fourteen (14) layer copper foil flexible follower is placed on the rail with a fixture. The fixture is placed in a quartz tube hooked up to a vacuum system, evacuated and placed in a tube furnace and heated up to the prescribed temperature. When the parts reach temperature, the 
furnace is shut-off, the tube removed and allowed to cool down while under vacuum. After cooling, a rivet is installed through the copper follower into the cold frame segment to give added assurance that the follower and segment will not separate, which could result in legs being displaced. After riveting, the assembly is placed in a fixture to form an " $\mathrm{S}$ " shape on each side of the rail. After forming the double loops on all followers on a segment, it is placed in another fixture so the cold current straps can be soldered to the follower.

The previous cold current soldered sub-assembly is now located with solder preforms so that the appropriate spring retainers protrude through the holes in the flexible followers. The sub-assemblies are soldered together in a vacuum to make up the cold end sub-assembly.

\section{O. INVESTIGATION OF ULTRASONIC WELDING OF COLD END HARDWARE}

A parallel effort was undertaken to bond cold end hardware ultrasonically in addition to the pressure-temperature bond method. Investigation was not completed due to the stop work order. From the work that was done, it appears that the layers of copper foils could be ultrasonically bonded to each other and to the copper buttons, spring retainers and P-leg discs. The copper to copper ultrasonic bond did not appear to be a major problem. The next step was to ultrasonically bond copper to aluminum.

In the SN-1 design, the aluminum is electroless nickel plated, a solder, $10 \%$ tin, $88 \%$ lead, $2 \%$ silver with flux in a vacuum is used to make the copper to aluminum bond. The ultrasonic weld would eliminate flux and the electroless nickel plate. Preliminary work and samples indicated feasibility and a successful weld could be made.

\section{P. FINAL ASSEMBLY}

Assembly tooling was redesigned and modified from GDS-I. Bars and clamps were used on the outside of the cold frame segments and rings. The GDS-I design used threaded rods and bosses. A partial dummy assembly was put together which indicated some additional changes and modifications to be made to the final assembly tooling. Due to the stop work order, a practice assembly of SN-1 was never accomplished.

\section{Q. EQUIPMENT}

At the initial planning, it was thought that the housing would be a cylinder which could be loaded in a normal size clean bench. After the program started, it was determined that the housing would have fins, possibly $24^{\prime \prime}$ to $30^{\prime \prime}$ long and up to $30^{\prime \prime}$ in diameter. After consultation with $3 \mathrm{M}$ Engineering it was decided that $3 \mathrm{M}$ would purchase and install ceiling mounted vertical laminar flow clean air modules. The modules were installed, inspected and certified to class 100 . This allowed work to take place under them in a space approximately $6 \mathrm{ft}$. by $12 \mathrm{ft}$. by $7 \frac{1}{2} \mathrm{ft}$. high.

\section{R. SPECIAL PROCESSING AND SHIPPING CONTAINERS}

Special large stainless steel vacuum processing containers which when mounted on supports and packaged in special crates could also be used as shipping containers. The opening in Teledyne's vacuum chamber (submarine) limited the size of the processing-shipping container which also limited the size of the external housing of SN-1. 


\section{QUALITY ENGINEERING AND CONTROL}

\section{A. QUALITY ASSURANCE}

The SIG/Galileo Quality Assurance Program Plan was completed and submitted to DoE (Report No. MMM-2864-0011). MSI-2008 and 2009 P-leg and N-leg materials fabrication specifications, Q.A. Standard Instructions and processing check sheets were completed and submitted to DoE. Inspection of all hardware and material ordered prior to the stop work order was completed

\section{B. CONFIGURATION MANAGEMENT}

The 3M computer programming department investigated and identified a computer system to maintain records for configuration management control.

\section{DOE ACCEPTANCE}

The acceptance data package description was completed and made an appendix to the $Q A$ Program Plan.

D. NON-DESTRUCTIVE TESTING PLAN

The NDT plan was completed and incorporated in the QA Program Plan. 


\section{RELIABILITY}

\section{A. RELIABILITY}

Reliability - The system of activities established to provide the level of reliability (probability that the equipment will perform adequately its intended function for the specified interval understated conditions) in the 3M Selenide Converter technology program to meet the needs of the user. The essential reliability tasks worked on are outlined as follows:

- Reliability Requirements

1) Determine

2) Study and Analyze

3) Promote through review of engineering, design, and manufacturing documents, specifications and drawings.

- Design Review

1) Inherent reliability is established and determined by the basic design

2) Determine the design factors which can be used as indices of quality and reliability of components and systems

3) Prepare FMECA for system

- Test Objectives

1) Establish methods for measuring and correlating design factors as related to quality and reliability of the system. i.e., acceptable value and range for each pertinent factor

2) Establish methods for assessing reliability determined within stated confidence limits from tests

3) Document test objective, independent and dependent variables, test conditions and methodology for obtaining, storing and recording data

- Evaluation and Assessment

1) Analysis of Variance (ANOVA) techniques (least squares regression analysis) for separating variabilities in collection of observations into components or sources

2) Develop model to predict long term performance

3) Verify reliability prediction by applicable tests using accelerated conditions as applicable to the stated time frame

- Failure Reporting System - The purpose of the failure reporting system is to ensure that all failures occurring during the program from material receiving inspection through performance testing of module designs are recorded and used for product improvement. 
A preliminary Program Plan for the Galileo Mission to delineate the specific tasks in the reliability area during design development, fabrication and test of deliverable thermoelectric converters for use in the Galileo Mission was submitted to DoE in January 1979. (Reference Report Number MMM-2864-0035).

A Thermoelectric Converter Failure Mode Effects and Criticality Analysis, FMECA, was prepared to identify the failure areas which could result in loss of electrical power during the mission. The purpose of the FMECA was to assure that all possible failure modes of the converter system, parts, manufacturing process or quality control system have been addressed. Summarizing, the purpose of the FMECA was to identify potential and known failure modes; identify the causes and effects of such failure modes; prioritize the identified failure modes according to frequency of occurrence, severity and detection; and provide for problem follow-up and corrective action. The criteria for FMECA Analysis is listed in Attachment 14.

A preliminary copy of the FMECA is included as attachment 14.

A system failure mode logic diagram was prepared to indicate logical combinations of failure modes leading to converter failure as identified by the FMECA and provide a basis for allocating the failure probabilities of the system to the component failure modes. Included in this work were Fault Tree Analyses made of the $\mathrm{P}$ and $\mathrm{N}$-legs. These diagrams are included in the appendix. These system and component diagrams were developed to identify causative events and their logical relationships to a specified undesired event or failure mode. The technique identifies the failures through the causational events and their logical relationship, beginning at the undesired or top event and proceeding downward through the various operational modes and subsystems to the component level. The definition of the logical relationships between these causational events allows the quantitative analysis of the probability of the undesired event using the basic rules of probability.

The reliability effort also extended to contributions made to post test analysis (PTA) made of operational modules removed from test. Computer programs of the module data were obtained which reduced the data to individual leg parametric performance. Thus, individual leg performance could be easily compared and correlated with observations made on PTA disassemblies.

A failure reporting system was proposed to ensure that all failures occurring during the program from material receiving inspection through acceptance testing of the converter are recorded and utilized for product improvement.

Quality control would report deviations and failures during material receiving, during fabrication and production of converters; Reliability would perform this function for acceptance testing. The form used for reporting would be that shown on the following page entitled the "Failure Report Form".

A Failure Review Board (FRB) or Committee composed of members representing the different work areas of the program as shown in the Work Interface Chart would receive the failure report. The FRB analyzes the failed item, determines the appropriate corrective action for recommendation to DoE. After appropriate action has been determined, the Failure Review Board Coordinator initiates the action, monitors its progress, and schedules an audit follow-up. After the action and audit are completed, the Coordinator forwards a verification notice and the corrective action findings to the FRB, which in turn completes the "Failure Review Report". The block diagram of the failure reporting system and the Failure Review Report form are shown on the following pages. 
FAILURE REPORT FORM DATE REPORT NO.

ITEM NAME. ITEM DRAWING NO.

DATE OF FAILURE

FAILURE DESCRIPTION

APPLICABLE SPECIFICATION

DEVIATION 


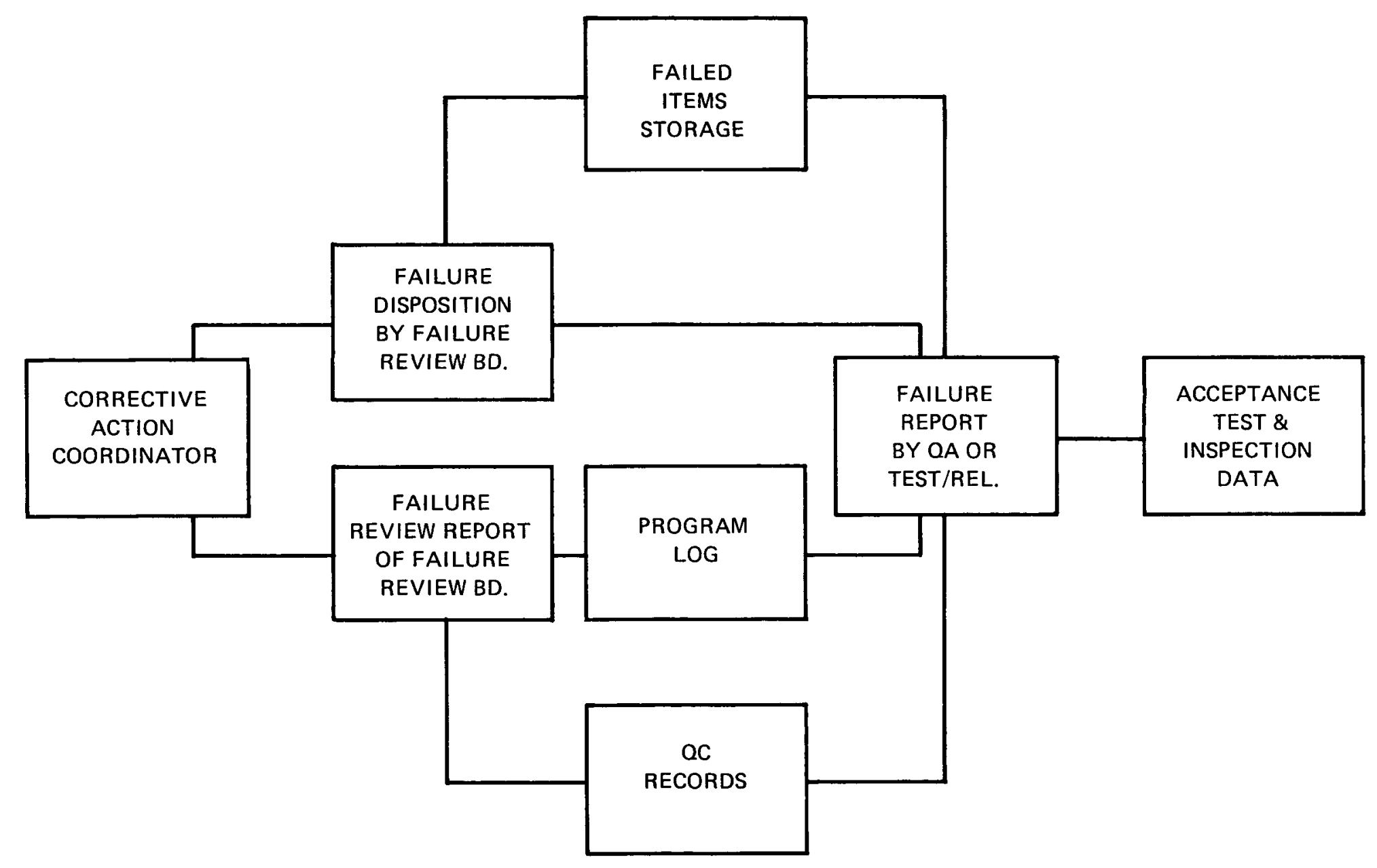

FIGURE 5: FLOW PLAN FOR FAILURE REPORTING AND REVIEW SYSTEM 


\section{DATE}

REPORT NO.

ITEM NAME ITEM DRAWING NO.

DATE OF FAILURE

FAILURE DESCRIPTION

FAILURE ANALYSIS

CORRECTIVE ACTION

CORRECTIVE ACTION EFFECTIVE ON DSN

MAT'L

MFG

REL

PROG.

QA 
VI-6

ATTACHMENT TO SECTION VI 


\section{ATTACHMENT 14}

Criteria For FMECA Analysis

1) Assumed Failure Mode

Description of each possible failure mode anticipated. The question to be considered is "Could It?" as opposed to "Will it?"

2) Assumed Cause of Failure

Listing of all causes assignable to each failure mode. Care will be taken to assure that the list is inclusive so that remedial effort will be aimed at all pertinent causes.

3) Effect on Mission Performance

In as far as is possible, expressing the effect in terms of converter power output change.

4) Probability of Failure Mode Occurrence

The probability of occurrence is evaluated on a "0.1" to "10" scale. As an example, a "0.1" indicates a very improbable occurrence, whereas "10" would indicate a very probable occurrence.

5) Severity of Failure Mode Occurrence

The severity or estimated consequence of the failure is evaluated on a " 0.1 " to " 10 " scale. A " 0.1 " indicates a minor nuisance, whereas a " 10 " indicates a severe total failure of mission power.

6) Detection of Failure Mode Occurrence

The number assigned here is based on the estimated probability that a potential problem can be detected while corrective action can be taken. $A$ " 0.1 " indicates a high probability that the failure would be detected, while a "10" indicates a low probability that the failure would be detected.

7) Risk Priority Number

The product of the numbers for probability, severity, and detection previously evaluated for a specific failure mode provides an indicator of the relative priority or criticality of the failure mode.

8) Proposed Course of Action

A brief description of the correction action recommended including those responsible for resolution.

From the risk priority number, a criticality analysis rating becomes readily apparent as an indication of areas of emphasis for improved reliability. 
TABLE 141: 1 FAILURE MODE EFFECTS AND CRITICALITY ANALYSIS (FMECA)

\begin{tabular}{|c|c|c|c|c|c|c|c|c|c|c|}
\hline \multicolumn{2}{|r|}{ ITEM } & \multirow{2}{*}{$\begin{array}{l}\text { ASSUMED } \\
\text { FAILURE } \\
\text { MODE }\end{array}$} & \multirow{2}{*}{$\begin{array}{l}\text { ASSUMED } \\
\text { CAUSE OF } \\
\text { FAILURE }\end{array}$} & \multirow{2}{*}{$\begin{array}{l}\text { EFFECT } \\
\text { ON MISSION } \\
\text { PERFORMANCE }\end{array}$} & \multirow{2}{*}{$\begin{array}{l}\text { COMPEN- } \\
\text { SATING } \\
\text { PROVISIONS }\end{array}$} & \multicolumn{3}{|c|}{$\begin{array}{l}\text { FAILURE MODE } \\
\text { OCCURRENCE }\end{array}$} & \multirow{2}{*}{$\begin{array}{l}\text { RISK } \\
\text { PRIOR- } \\
\text { ITY } \\
\text { NO. }\end{array}$} & \multirow{2}{*}{$\begin{array}{l}\text { PROPOSED } \\
\text { COURSE OF } \\
\text { ACTION }\end{array}$} \\
\hline $\begin{array}{l}\text { DES- } \\
\text { CRIP- } \\
\text { TION }\end{array}$ & & & & & & $\begin{array}{l}\text { PROBA- } \\
\text { BILITY } \\
\text { OF }\end{array}$ & $\begin{array}{l}\text { OCCURRE } \\
\text { SEVER- } \\
\text { ITY } \\
\text { OF }\end{array}$ & $\begin{array}{l}\text { DEETEC- } \\
\text { DION } \\
\text { OF }\end{array}$ & & \\
\hline $\begin{array}{l}\text { 1. HOT } \\
\text { END }\end{array}$ & \multirow{3}{*}{\begin{tabular}{l}
\multicolumn{1}{c}{ A. } \\
SPACER \\
(POCO \\
GRAPHITE \\
MATERIAL)
\end{tabular}} & \multirow{3}{*}{$\begin{array}{l}\text { 1. CRACKING. } \\
\text { 2. BREAKING OR } \\
\text { SPALLING } \\
\text { 3. SHATTERING }\end{array}$} & \multirow{3}{*}{$\begin{array}{l}\text { DYNAMIC VIBRATION } \\
\text { AND HANDLING INIT- } \\
\text { IATE HIGH STRESSES } \\
\text { WHICH CAUSE FAILURE } \\
\text { DUE TO INHERENT } \\
\text { MATERIAL DEFECTS. }\end{array}$} & \multirow{3}{*}{$\begin{array}{l}\text { LOSS OF A PORTION } \\
\text { OR ALL OF CONVER. } \\
\text { TOR OUTPUT POWER. }\end{array}$} & \multirow{3}{*}{$\begin{array}{l}\text { MOST LIKELY TYPE } \\
\text { OF CRACK WOULD } \\
\text { HAVE MINOR EFFECT. }\end{array}$} & .2 & 1 & 10 & 2 & \multirow[t]{3}{*}{ Q.C. PROGRAM } \\
\hline \multirow{9}{*}{$\begin{array}{l}\text { HARD } \\
\text { WARE }\end{array}$} & & & & & & .2 & 5 & 7 & 7 & \\
\hline & & & & & & .1 & 10 & .1 & .1 & \\
\hline & \multirow[t]{2}{*}{$\begin{array}{l}\text { B. } \\
\text { HOT SHOE } \\
\text { FOIL }\end{array}$} & \multirow[t]{2}{*}{$\begin{array}{l}\text { 1. ELECTRICAL } \\
\text { SHORT CIRCUIT } \\
\text { TO SPACER. }\end{array}$} & \multirow[t]{2}{*}{$\begin{array}{l}\text { DYNAMIC VIBRATION } \\
\text { CAUSES GIMBAL TO } \\
\text { TOUCH FOIL AND/OR } \\
\text { SPACER. }\end{array}$} & $\begin{array}{l}\text { VARIES FROM REDUC- } \\
\text { TION IN OUTPUT TO } \\
\text { TOTAL LOSS OF GEN- } \\
\text { ERATOR OUTPUT. }\end{array}$ & & 1 & 1 & 10 & 10 & $\begin{array}{l}\text { Q.C. PROGRAM } \\
\text { REQUEST ELEC- } \\
\text { TRICAL FLOAT- }\end{array}$ \\
\hline & & & & $\begin{array}{l}\text { A SHORT TO GROUND } \\
\text { COULD POSSIBLY } \\
\text { PRODUCE AN UNDE- } \\
\text { SIRABLE CONDITION } \\
\text { FOR THE LOAD. }\end{array}$ & & & & & & ATOR FRAME. \\
\hline & \multirow[t]{2}{*}{$\begin{array}{l}\quad \text { C. } \\
\text { HOT END } \\
\text { CURRENT } \\
\text { STRAP } \\
\text { INSULA- } \\
\text { TION } \\
\text { A1 } \mathbf{2}^{0_{3}}\end{array}$} & $\begin{array}{l}\text { 1. ELECTRICAL } \\
\text { SHORT CIRCUIT } \\
\text { TO HOT SHOE. }\end{array}$ & $\begin{array}{l}\text { IMPURITIES, METAL } \\
\text { PARTICLES, CRACKED } \\
\text { INSULATION, THER- } \\
\text { MAL CYCLING. }\end{array}$ & $\begin{array}{l}\text { REDUCED OUTPUT } \\
\text { FROM THE AFFECTED } \\
\text { ELEMENTS. INCREAS- } \\
\text { ED HOT SPACER TEMP- } \\
\text { ERATURE MAY CAUSE } \\
\text { EXCESSIVE HEATING } \\
\text { OF THE OTHER ELE- } \\
\text { MENTS. }\end{array}$ & $\begin{array}{l}\text { MOST LIKELY TYPE } \\
\text { OF CRACK WOULD } \\
\text { HAVE MINOR EFFECT. }\end{array}$ & .1 & 2 & 1 & .2 & \\
\hline & & $\begin{array}{l}\text { 2. TRANSVERSE } \\
\text { CRACK SEPAR- } \\
\text { ATES HOT END } \\
\text { INSULATION } \\
\text { INTO TWO OR } \\
\text { MORE PIECES. }\end{array}$ & $\begin{array}{l}\text { EXCESSIVE COEFFIC- } \\
\text { IENT OF FRICTION } \\
\text { AND STRESSES DUE } \\
\text { TO THERMAL CYC- } \\
\text { LING. }\end{array}$ & $\begin{array}{l}\text { EXCESSIVE RELATIVE } \\
\text { MOTION CAUSES AN } \\
\text { INCREASE IN HOT } \\
\text { JUNCTION RESIS- } \\
\text { TANCE. }\end{array}$ & & .1 & 2 & 9 & 1.8 & \\
\hline & $\begin{array}{l}\text { D. } \\
\text { CERAMIC } \\
\text { PIN }\end{array}$ & $\begin{array}{l}\text { 1. SHEARED, } \\
\text { CRACKED OR } \\
\text { BROKEN PIN } \\
\text { CAUSING SHIFT- } \\
\text { ING OF CURRENT } \\
\text { STRAP. }\end{array}$ & $\begin{array}{l}\text { DYNAMIC VIBRATION } \\
\text { AND STRESSES DUE } \\
\text { TO THERMAL CYCL- } \\
\text { LING. }\end{array}$ & $\begin{array}{l}\text { REDUCED OUTPUT } \\
\text { FROM THE AFFECTED } \\
\text { ELEMENTS }\end{array}$ & & 1 & 1 & 10 & 10 & Q.C. PROGRAM \\
\hline & \multirow[t]{2}{*}{\begin{tabular}{l}
\multicolumn{1}{c}{ E. } \\
HOT END \\
CURRENT \\
STRAP
\end{tabular}} & \multirow{2}{*}{$\begin{array}{l}\text { HIGH ELECTRICAL } \\
\text { RESISTANCE ON } \\
\text { OPEN CIRCUIT OF } \\
\text { CURRENT STRAP } \\
\text { OR ELEMENTS. }\end{array}$} & $\begin{array}{l}\text { 1. FOREIGN MATERIAL } \\
\text { DURING ASSEMBLY. }\end{array}$ & $\begin{array}{l}\text { REDUCED OUTPUT } \\
\text { DUE TO EXCESSIVE } \\
\text { RESISTANCE. }\end{array}$ & $\begin{array}{l}\text { WOULD BE DETECTED } \\
\text { DURING CHECKOUT } \\
\text { AND PROCESSING }\end{array}$ & .1 & 2 & 1 & .2 & $\begin{array}{l}\text { ASSEMBLE CON- } \\
\text { VERTOR IN } \\
\text { CONTROLLED } \\
\text { AREA. }\end{array}$ \\
\hline & & & $\begin{array}{l}\text { 2. THERMAL INSULA- } \\
\text { TION WORKS INTO } \\
\text { THE AREA BETWEEN } \\
\text { THE ELEMENT AND } \\
\text { CURRENT STRAP } \\
\text { AND/OR GIMBAL } \\
\text { THERMAL CYCLING } \\
\text { AND/OR VIBRATION. }\end{array}$ & $\begin{array}{l}\text { REDUCED OUTPUT } \\
\text { FROM THE AFFECTED } \\
\text { ELEMENTS. INCREAS- } \\
\text { ED HOT SPACON } \\
\text { TEMPERATURE MAY } \\
\text { CAUSE EXCESSIVE } \\
\text { HEATING OF THE } \\
\text { OTHER ELEMENTS }\end{array}$ & & .1 & 2 & 8 & 1.6 & \\
\hline
\end{tabular}


TABLE 14-2: 2 FAILURE MODE EFFECTS AND CRITICALITY ANALYSIS (FMECA)

\begin{tabular}{|c|c|c|c|c|c|c|c|c|c|c|}
\hline \multicolumn{2}{|c|}{ ITEM } & \multirow{2}{*}{$\begin{array}{l}\text { ASSUMED } \\
\text { FAILURE } \\
\text { MODE }\end{array}$} & \multirow{2}{*}{$\begin{array}{l}\text { ASSUMED } \\
\text { CAUSE OF } \\
\text { FAILURE }\end{array}$} & \multirow{2}{*}{$\begin{array}{l}\text { EFFECT } \\
\text { ON MISSION } \\
\text { PERFORMANCE }\end{array}$} & \multirow{2}{*}{$\begin{array}{l}\text { COMPEN- } \\
\text { SATING } \\
\text { PROVISIONS }\end{array}$} & \multicolumn{3}{|c|}{$\begin{array}{c}\text { FAILURE MODE } \\
\text { OCCURRENCE }\end{array}$} & \multirow{2}{*}{$\begin{array}{l}\text { RISK } \\
\text { PRIOR- } \\
\text { ITY } \\
\text { NO. }\end{array}$} & \multirow{2}{*}{$\begin{array}{l}\text { PROPOSED } \\
\text { COURSE OF } \\
\text { ACTION }\end{array}$} \\
\hline $\begin{array}{l}\text { DES- } \\
\text { CRIP. } \\
\text { TION }\end{array}$ & DETAIL & & & & & \begin{tabular}{l}
\multicolumn{1}{|r}{ OC } \\
PROBA- \\
BILITY \\
OF. \\
\end{tabular} & $\begin{array}{l}\text { CURRENC } \\
\text { SEVER- } \\
\text { ITY } \\
\text { OF } \\
\end{array}$ & $\begin{array}{l}\text { CE } \\
\text { DETEC- } \\
\text { TION } \\
\text { OF } \\
\end{array}$ & & \\
\hline \multirow[t]{12}{*}{$\begin{array}{l}\text { 2. THERM- } \\
\text { O-ELEC- } \\
\text { TRIC } \\
\text { ELE- } \\
\text { MENT }\end{array}$} & \multirow[t]{12}{*}{$\begin{array}{l}\text { A. } \\
\text { N-TYPE } \\
\text { LEG }\end{array}$} & \multirow[t]{6}{*}{ 1. CRACKING } & 1. THERMAL CYCLING. & \multirow{6}{*}{$\begin{array}{l}\text { SPRING PRESSURE } \\
\text { MAY MAINTAIN NEAR- } \\
\text { LY CONSTANT OUT- } \\
\text { PUT, BUT SENSITIVITY } \\
\text { TO SHOCK AND VIB- } \\
\text { RATION WILL BE IN- } \\
\text { CREASED. }\end{array}$} & & 1 & 1 & 9 & 9 & $\begin{array}{l}\text { LIMIT THE } \\
\text { NUMBER OF } \\
\text { THERMAL } \\
\text { CYCLES }\end{array}$ \\
\hline & & & $\begin{array}{l}\text { 2. IMPROPER FAB- } \\
\text { RICATION OF ELE- } \\
\text { MENT. }\end{array}$ & & \multirow[t]{2}{*}{$\begin{array}{l}\text { WOULD BE FOUND } \\
\text { IN OC CHECKS. }\end{array}$} & .1 & 1 & 9 & .9 & \multirow[t]{3}{*}{ Q.C. PROGRAM } \\
\hline & & & $\begin{array}{l}\text { 3. IMPROPER ASSEMBLY } \\
\text { OF GENERATOR. }\end{array}$ & & & .1 & 1 & 9 & .9 & \\
\hline & & & $\begin{array}{l}\text { 4. EXCESSIVE STRESS } \\
\text { EXERTED ON ELEMENT } \\
\text { DURING FABRICA- } \\
\text { TION OR INSPECTION. }\end{array}$ & & & .1 & 1 & 9 & .9 & \\
\hline & & & $\begin{array}{l}\text { 5. TRANSFORMATION } \\
\text { OF MATERIAL }\end{array}$ & & & 10 & 1 & 9 & 90 & \\
\hline & & & $\begin{array}{l}\text { 6. EXCESSIVE CURRENT } \\
\text { BECAUSE HIGH RE- } \\
\text { SISTANCE IN ONE } \\
\text { LEG CIRCUITS. }\end{array}$ & & & 1 & 1 & 10 & 10 & \\
\hline & & \multirow[t]{2}{*}{$\begin{array}{l}\text { 2. CHANGE IN } \\
\text { DOPING LEVEL. }\end{array}$} & $\begin{array}{l}\text { 1. OXYGEN IN SYSTEM } \\
\text { CAUSED BY OUT- } \\
\text { GASSING OF INSU- } \\
\text { LATION }\end{array}$ & \multirow{2}{*}{$\begin{array}{l}\text { GRADUAL REDUC- } \\
\text { TION GENERATOR } \\
\text { OUTPUT POWER. } \\
\text { EXTENT OF REDUC- } \\
\text { TION WILL BE LIMIT. } \\
\text { ED. }\end{array}$} & \multirow[t]{2}{*}{$\begin{array}{l}\text { INSULATION PRO. } \\
\text { CESSING CONTROL. }\end{array}$} & .1 & 5 & 2 & 1 & O.C. PROGRAM \\
\hline & & & $\begin{array}{l}\text { 2. CAUSED BY FAILURE } \\
\text { OF SEAL DURING } \\
\text { TERRESTRIAL OPER- } \\
\text { ATION. }\end{array}$ & & & .1 & 10 & 1 & 1 & \\
\hline & & \multirow[t]{4}{*}{$\begin{array}{l}\text { 3. EXCESSIVE } \\
\text { RESISTANCE }\end{array}$} & $\begin{array}{l}\text { 1. IMPROPER FABRICA- } \\
\text { TION OF COLD END } \\
\text { BOND AND/OR } \\
\text { SPATTERING. }\end{array}$ & $\begin{array}{l}\text { HIGH GENERATOR RE- } \\
\text { SISTANCE. INCREAS- } \\
\text { ED SENSITIVITY TO } \\
\text { VIBRATION. }\end{array}$ & $\begin{array}{l}\text { SPRING PRESSURE } \\
\text { PREVENTS COMPL. } \\
\text { ETE FAILURE. } \\
\text { THIS CONDITION } \\
\text { COULD POSSIBLY BE } \\
\text { DETECTED BY ULTRA- } \\
\text { SONIC MEASUREMENT } \\
\text { TECHNIQUE, RESIS- } \\
\text { TANCE VERSUS } \\
\text { LENGTH MEASURE. } \\
\text { MENT, AND/OR PULL } \\
\text { TEST. } \\
\end{array}$ & .1 & 1 & 9 & .9 & O.C. PROGRAM \\
\hline & & & $\begin{array}{l}\text { 2. POOR ELEMENT ALI- } \\
\text { GNMENT DURING } \\
\text { ASSEMBLY. }\end{array}$ & $\begin{array}{l}\text { LOW OUTPUT POWER } \\
\text { DUE TO HIGH GEN- } \\
\text { ERATOR RESISTANCE. }\end{array}$ & $\begin{array}{l}\text { WOULD BE DETECTED } \\
\text { DURING PROCESSING. }\end{array}$ & 1 & 2 & 4 & 8 & $\begin{array}{l}\text { MODULE TESTS } \\
\text { TO IDENTIFY } \\
\text { PROBLEMS. }\end{array}$ \\
\hline & & & $\begin{array}{l}\text { 3. CONTAMINATION } \\
\text { FROM TEG MATER- } \\
\text { IALS. }\end{array}$ & \multirow[t]{2}{*}{ LOW OUTPUT POWER } & \multirow[t]{2}{*}{$\begin{array}{l}\text { WOULD BE DETECTED } \\
\text { DURING PROCESSING. }\end{array}$} & 1 & 1 & 10 & 10 & $\begin{array}{l}\text { MODULE TESTS } \\
\text { TO IDENTIFY } \\
\text { PROBLEMS. } \\
\end{array}$ \\
\hline & & & $\begin{array}{l}\text { 4. OXIDATION OF INTER- } \\
\text { FACES. }\end{array}$ & & & 1 & 2 & 4 & 8 & \\
\hline
\end{tabular}


TABLE 14-3: 3 FAILURE MODE EFFECTS AND CRITICALITY ANALYSIS (FMECA)

\begin{tabular}{|c|c|c|c|c|c|c|c|c|c|c|}
\hline \multicolumn{2}{|c|}{ ITEM } & \multirow{2}{*}{$\begin{array}{l}\text { ASSUMED } \\
\text { FAILURE } \\
\text { MODE }\end{array}$} & \multirow{2}{*}{$\begin{array}{l}\text { ASSUMED } \\
\text { CAUSE OF } \\
\text { FAILURE }\end{array}$} & \multirow{2}{*}{$\begin{array}{l}\text { EFFECT } \\
\text { ON MISSION } \\
\text { PERFORMANCE }\end{array}$} & \multirow{2}{*}{$\begin{array}{l}\text { COMPEN- } \\
\text { SATING } \\
\text { PROVISIONS }\end{array}$} & \multicolumn{3}{|c|}{$\begin{array}{l}\text { FAILURE MODE } \\
\text { OCCURRENCE }\end{array}$} & \multirow{2}{*}{$\begin{array}{l}\text { RISK } \\
\text { PRIOR- } \\
\text { ITY } \\
\text { NO. }\end{array}$} & \multirow{2}{*}{$\begin{array}{l}\text { PROPOSED } \\
\text { COURSE OF } \\
\text { ACTION }\end{array}$} \\
\hline $\begin{array}{l}\text { DES- } \\
\text { CRIP- } \\
\text { TION }\end{array}$ & DETAIL & & & & & $\begin{array}{l}\text { OC } \\
\text { PROBA- } \\
\text { BILITY } \\
\text { OF }\end{array}$ & $\begin{array}{l}\text { CCURRER } \\
\text { SEVER- } \\
\text { ITY } \\
\text { OF } \\
\end{array}$ & $\begin{array}{l}\text { CE } \\
\text { DETEC- } \\
\text { TION } \\
\text { OF }\end{array}$ & & \\
\hline \multirow[t]{15}{*}{$\begin{array}{l}\text { 2. THER- } \\
\text { MO-ELE- } \\
\text { CTRIC } \\
\text { ELE- } \\
\text { MENT }\end{array}$} & \multirow[t]{3}{*}{$\begin{array}{l}\text { B. } \\
\text { P-TYPE } \\
\text { LEG }\end{array}$} & \multirow[t]{3}{*}{$\begin{array}{l}\text { A. CRACKING AT } \\
\text { THE COLD } \\
\text { JUNCTION. }\end{array}$} & $\begin{array}{l}\text { 1. THERMAL CYCLING } \\
\text { THROUGH THE MA- } \\
\text { TERIAL'S TRAN- } \\
\text { SITION. }\end{array}$ & \multirow{3}{*}{$\begin{array}{l}\text { SPRING PRESSURE MA } \\
\text { MAINTAIN NEARLY } \\
\text { CONSTANT OUTPUT, } \\
\text { BUT SENSITIVITY TO } \\
\text { SHOCK AND VIBRA- } \\
\text { TION WILL BE INCREA- } \\
\text { SED. }\end{array}$} & & 2 & 3 & 10 & 60 & $\begin{array}{l}\text { LIMIT THE NUM- } \\
\text { BER OF TEMP. } \\
\text { ERATURE CYCLES. }\end{array}$ \\
\hline & & & $\begin{array}{l}\text { 2. OPERATING THE } \\
\text { MATERIAL BELOW } \\
\text { ITS TEMPERATURE } \\
\text { RANGE. } \\
\end{array}$ & & & 1 & 3 & 10 & 30 & $\begin{array}{l}\text { DESIGN CONVER- } \\
\text { TER NOT TO OPER- } \\
\text { ATE IN THIS RANGE }\end{array}$ \\
\hline & & & $\begin{array}{l}\text { 3. EXCESSIVE STRESS } \\
\text { EXERTED ON ELE- } \\
\text { MENT DURING } \\
\text { ASSEMBLY. }\end{array}$ & & & .1 & 3 & 1 & .3 & Q.C.PROGRAM \\
\hline & & & $\begin{array}{l}\text { 4. IMPROPER BONDING } \\
\text { OF ELEMENT COLD } \\
\text { CONTACT. }\end{array}$ & & & .1 & 3 & 1 & .3 & \\
\hline & & \multirow[t]{5}{*}{ B. SUBLIMATION } & $\begin{array}{l}\text { 1. EXCESSIVE OPERA- } \\
\text { TING TEMPERATURE, } \\
\text { CHANGING DOPANT } \\
\text { DISTRIBUTION. }\end{array}$ & \multirow{5}{*}{$\begin{array}{l}\text { NO SHORT-TERM } \\
\text { EFFECTS, LONG-TERM } \\
\text { COPPER GROWTH AT } \\
\text { PARTITION AND COLD } \\
\text { END. CONDENSATION } \\
\text { OF SUBLIMATION PRO. } \\
\text { DUCT ON INSULATION } \\
\text { INCREASES THERMAL } \\
\text { LOSS OR ELECTRICAL } \\
\text { SHORT. COPPER } \\
\text { GROWTH COULD } \\
\text { CAUSE ELECTRICAL } \\
\text { SHORTING. }\end{array}$} & \multirow[t]{5}{*}{$\begin{array}{l}\text { THE ELECTRICAL } \\
\text { PROPERTIES OF } \\
\text { THE MATERIAL } \\
\text { ARE NOT AFFECTED. }\end{array}$} & 3 & 3 & 9 & 81 & \multirow[t]{5}{*}{ O.C.PROGRAM } \\
\hline & & & $\begin{array}{l}\text { 2. EXCESSIVE OPERA- } \\
\text { TING CURRENT BE- } \\
\text { CAUSE OF FAILURE } \\
\text { OF ADJACENT LEG } \\
\text { IN PARALLEL SET } \\
\text { CAUSING CHANGE IN } \\
\text { DOPANT DISTRI- } \\
\text { BUTION. }\end{array}$ & & & 1 & 8 & 10 & 80 & \\
\hline & & & 3. FAILURE OF WRAP. & & & 3 & 8 & 9 & 216 & \\
\hline & & & $\begin{array}{l}\text { 4. LOSS OF WRAP CON- } \\
\text { TACT SEAL AT HOT } \\
\text { JUNCTION FOIL FOR } \\
\text { INTERFACE. }\end{array}$ & & & $\mathbf{5}$ & 8 & 8 & 320 & \\
\hline & & & 5. OXYGEN IN SYSTEM. & & & .1 & 3 & 2 & .6 & \\
\hline & & \multirow[t]{2}{*}{$\begin{array}{l}\text { C. CHANGE IN } \\
\text { DOPANT LEVEL }\end{array}$} & 1. OXYGEN IN SYSTEM. & \multirow[t]{2}{*}{$\begin{array}{l}\text { REDUCTION IN CON- } \\
\text { VERTER OUTPUT }\end{array}$} & \multirow{2}{*}{$\begin{array}{l}\text { SEEBECK COEFFIENT } \\
\text { AND RESISTANCE } \\
\text { OF LEG WILL RE- } \\
\text { TURN TO NORMAL } \\
\text { WHEN OXYGEN IS } \\
\text { GONE. }\end{array}$} & .1 & 1 & 2 & .2 & \\
\hline & & & $\begin{array}{l}\text { 2. CONTAMINATION } \\
\text { FROM GENERATOR } \\
\text { MATERIALS. }\end{array}$ & & & .1 & 1 & 10 & 1 & $\begin{array}{l}\text { COMPATIBILITY } \\
\text { PROGRAM }\end{array}$ \\
\hline & & \multirow[t]{4}{*}{$\begin{array}{l}\text { D. EXCESSIVE } \\
\text { RESISTANCE }\end{array}$} & $\begin{array}{l}\text { 1. POOR ELEMENT ALI- } \\
\text { GNMENT DURING } \\
\text { ASSEMBLY }\end{array}$ & \multirow[t]{4}{*}{$\begin{array}{l}\text { REDUCTION IN CON. } \\
\text { VERTER OUTPUT }\end{array}$} & \multirow[t]{4}{*}{ 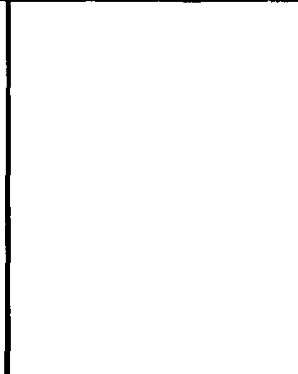 } & 1 & 1 & 1 & 1 & \\
\hline & & & $\begin{array}{l}\text { 2. CONTAMINATION } \\
\text { FROM TEG ASSEMB. } \\
\text { BLY MATERIAL. } \\
\end{array}$ & & & .1 & 1 & 10 & 1 & \\
\hline & & & $\begin{array}{l}\text { 3. CONTAMINATION } \\
\text { FROM WRAP PAR- } \\
\text { TICLES. }\end{array}$ & & & 1 & 5 & 10 & 50 & \\
\hline & & & $\begin{array}{l}\text { 4. OXIDATION OF } \\
\text { INTERFACES }\end{array}$ & & & 1 & 2 & 4 & 8 & \\
\hline
\end{tabular}


TABLE 144: 4 FAILURE MODE EFFECTS AND CRITICALITY ANALYSIS (FMECA)

\begin{tabular}{|c|c|c|c|c|c|c|c|c|c|c|}
\hline \multicolumn{2}{|c|}{ ITEM } & \multirow{2}{*}{$\begin{array}{l}\text { ASSUMED } \\
\text { FAILURE } \\
\text { MODE }\end{array}$} & \multirow{2}{*}{$\begin{array}{l}\text { ASSUMED } \\
\text { CAUSE OF } \\
\text { FAILURE }\end{array}$} & \multirow{2}{*}{$\begin{array}{l}\text { EFFECT } \\
\text { ON MISSION } \\
\text { PERFORMANCE }\end{array}$} & \multirow{2}{*}{$\begin{array}{l}\text { COMPEN- } \\
\text { SATING } \\
\text { PROVISIONS }\end{array}$} & & \multirow{2}{*}{$\begin{array}{l}\text { RISK } \\
\text { PRIOR- } \\
\text { ITY } \\
\text { NO. }\end{array}$} & \multirow{2}{*}{$\begin{array}{l}\text { PROPOSED } \\
\text { COURSE OF } \\
\text { ACTION }\end{array}$} \\
\hline $\begin{array}{l}\text { DES- } \\
\text { CRIP. } \\
\text { TION }\end{array}$ & DETAIL & & & & & $\begin{array}{l}\text { OC } \\
\text { PROBA- } \\
\text { BILITY } \\
\text { OF } \\
\end{array}$ & $\begin{array}{l}\text { SURREN } \\
\text { ITY } \\
\text { OF } \\
\end{array}$ & $\begin{array}{l}\text { CE } \\
\text { DETEC- } \\
\text { TION } \\
\text { OF } \\
\end{array}$ & & \\
\hline \multirow[t]{14}{*}{$\begin{array}{l}\text { 3. COLD } \\
\text { END } \\
\text { HARD. } \\
\text { WARE }\end{array}$} & \multirow[t]{5}{*}{$\begin{array}{l}\quad \text { A. } \\
\text { FOIL } \\
\text { COLD } \\
\text { STRAP }\end{array}$} & $\begin{array}{l}\text { 1. POOR THERMAL } \\
\text { CONTACT IN } \\
\text { FOLLOWER } \\
\text { RAIL ASSEMBLY }\end{array}$ & $\begin{array}{l}\text { POOR BONDS AT JOIN- } \\
\text { ING SURFACES. }\end{array}$ & \multirow{3}{*}{$\begin{array}{l}\text { INCREASES THERMAL } \\
\text { IMPEDANCE, CAUSES } \\
\text { HIGHER JUNCTION } \\
\text { TEMPERATURES, RE- } \\
\text { SULTS IN REDUCED } \\
\text { POWER OUTPUT. }\end{array}$} & \multirow[t]{2}{*}{$\begin{array}{l}\text { RIVETS ADDED TO } \\
\text { BONDS }\end{array}$} & .1 & 2 & 2 & 4 & \multirow[t]{2}{*}{ O.C.PROGRAM } \\
\hline & & $\begin{array}{l}\text { 2. HOLES FORMED } \\
\text { IN COLD STRAP. }\end{array}$ & $\begin{array}{l}\text { CORROSION OF COLD } \\
\text { STRAPS. }\end{array}$ & & & 8 & 7 & 10 & 560 & \\
\hline & & $\begin{array}{l}\text { 3. TEARING OF } \\
\text { ONE OR MORE } \\
\text { CURRENT } \\
\text { STRAPS. } \\
\end{array}$ & VIBRATION & & $\begin{array}{l}\text { TESTS SHOW AD- } \\
\text { EQUATE DESIGN. }\end{array}$ & .5 & 7 & 10 & 35 & Q.C.PROGRAM \\
\hline & & \multirow[t]{2}{*}{$\begin{array}{l}\text { 4. LOSS OF FREE- } \\
\text { DOM OF FOIL } \\
\text { COLD STRAP. }\end{array}$} & $\begin{array}{l}\text { 1. BONDING ON STIFF- } \\
\text { ENING OF COLD } \\
\text { STRAP LAYERS. }\end{array}$ & \multirow{2}{*}{$\begin{array}{l}\text { INCREASE OF COLD } \\
\text { JUNCTION TEMPERA- } \\
\text { TURE DUE TO RE. } \\
\text { DUCTION IN THE } \\
\text { FORCE WITH CONSE- } \\
\text { QUENT LOSS OF } \\
\text { POWER. }\end{array}$} & \multirow[t]{2}{*}{$\begin{array}{l}\text { LONG TERM ACCEL- } \\
\text { ERATED COMPONENT } \\
\text { EVALUATION. }\end{array}$} & 2 & 5 & 10 & 100 & \multirow[t]{2}{*}{ Q.C.PROGRAM } \\
\hline & & & $\begin{array}{l}\text { 2. BLOCKING OF COLD } \\
\text { FOLLOWER ACTION } \\
\text { BY THERMAL INSU- } \\
\text { LATION AGING. }\end{array}$ & & & .5 & 5 & 10 & 25 & \\
\hline & \multirow{3}{*}{\begin{tabular}{|l} 
B. \\
BERYLIA \\
OXIDE \\
DISC IN- \\
SULATION
\end{tabular}} & \multirow[t]{3}{*}{$\begin{array}{l}\text { 1. ELECTRICAL } \\
\text { SHORT CIRCUIT. }\end{array}$} & $\begin{array}{l}\text { 1. IMPURITIES, METAL } \\
\text { PARTICLES, CRACKED } \\
\text { INSULATION, THERM. } \\
\text { AL CYCLING. }\end{array}$ & & & 2 & 2 & 1 & 4 & \multirow{3}{*}{$\begin{array}{l}\text { O.C. PROGRAM } \\
\text { COMPATIBILITY } \\
\text { PROGRAM }\end{array}$} \\
\hline & & & $\begin{array}{l}\text { 2. FOREIGN MATERIAL } \\
\text { DEPOSITED ACROSS } \\
\text { JOINT. }\end{array}$ & & & 7 & 5 & 10 & 350 & \\
\hline & & & $\begin{array}{l}\text { 3. CRACKING OF INSUL- } \\
\text { ATION. }\end{array}$ & & & .1 & 3 & 10 & 3 & \\
\hline & \multirow[t]{2}{*}{$\begin{array}{c}\text { C. } \\
\text { SPRINGS }\end{array}$} & $\begin{array}{l}\text { A. REDUCTION IN } \\
\text { SPRING FORCE. }\end{array}$ & $\begin{array}{l}\text { CHANGE OF MATERIAL } \\
\text { PROPERTIES WITH TIME } \\
\text { AT OPERATING TEMP. } \\
\text { ERATURE. }\end{array}$ & $\begin{array}{l}\text { INCREASED ELECTRIC- } \\
\text { AL RESISTANCE RE- } \\
\text { DUCES OUTPUT. IN- } \\
\text { CREASED THERMAL } \\
\text { IMPEDANCE INCREAS- } \\
\text { ES TEMPERATURE OF } \\
\text { HOT AND COLD JUNC- } \\
\text { TION. } \\
\end{array}$ & $\begin{array}{l}\text { TESTING MAKES } \\
\text { UNLIKELY }\end{array}$ & 6 & 8 & 10 & 480 & Q.C. PROGRAM \\
\hline & & B. BROKEN SPRING & $\begin{array}{l}\text { IMPROPER MANUFAC- } \\
\text { TURING. }\end{array}$ & $\begin{array}{l}\text { LOSS OF AT LEAST A } \\
\text { PORTION OF GENERA. } \\
\text { TOR OUTPUT. }\end{array}$ & $\begin{array}{l}\text { SERIES.PARALLEL } \\
\text { CONNECTION RE. } \\
\text { DUCES THE CHANGE } \\
\text { OF COMPLETE FAIL- } \\
\text { URE. }\end{array}$ & .1 & 2 & 10 & 2 & Q.C. PROGRAM \\
\hline & \multirow[t]{4}{*}{$\begin{array}{l}\text { D. } \\
\text { INTER. } \\
\text { CONNEC- } \\
\text { TIONS }\end{array}$} & \multirow[t]{3}{*}{$\begin{array}{l}\text { 1. ELECTRICAL } \\
\text { OPEN CIRCUIT }\end{array}$} & $\begin{array}{l}\text { 1. EXCESSIVE FLEX- } \\
\text { URE WHICH HAS } \\
\text { WEAKENED THE } \\
\text { WIRE AND CON- } \\
\text { NECTION. } \\
\end{array}$ & \multirow{3}{*}{$\begin{array}{l}\text { BREAKAGE RESULTS } \\
\text { IN THE LOSS OF AT } \\
\text { LEAST A PORTION } \\
\text { OF GENERATOR OUT. } \\
\text { PUT. VIBRATION } \\
\text { SENSITIVITY IS } \\
\text { INCREASED. }\end{array}$} & \multirow[t]{3}{*}{$\begin{array}{l}\text { STRANDED WIRE } \\
\text { PROVIDES MULTI- } \\
\text { PLE PATHS. }\end{array}$} & .01 & 7 & 10 & .7 & \multirow[t]{3}{*}{ Q.C. PROGRAM } \\
\hline & & & $\begin{array}{l}\text { 2. POOR BOND BE- } \\
\text { TWEEN WIRE AND } \\
\text { COLD STRAPS. } \\
\end{array}$ & & & 3 & 7 & 10 & 210 & \\
\hline & & & $\begin{array}{l}\text { 3. RIVET JUNCTION } \\
\text { FAILURE. } \\
\end{array}$ & & & 3 & 7 & 10 & 210 & \\
\hline & & $\begin{array}{l}\text { 2. ELECTRICAL } \\
\text { SHORT CIRCUIT }\end{array}$ & IMPROPER ASSEMBLY. & $\begin{array}{l}\text { VIBRATION MAY } \\
\text { CAUSE A CHANGE IN } \\
\text { OUTPUT. }\end{array}$ & $\begin{array}{l}\text { WOULD BE DETECT. } \\
\text { ED BY ACCEPTANCE } \\
\text { TESTS. }\end{array}$ & 3 & 7 & 10 & 210 & \\
\hline
\end{tabular}


TABLE 145: 5 FAILURE MODE EFFECTS AND CRITICALITY ANALYSIS (FMECA)

\begin{tabular}{|c|c|c|c|c|c|c|c|c|c|c|}
\hline \multicolumn{2}{|c|}{ ITEM } & \multirow{2}{*}{$\begin{array}{l}\text { ASSUMED } \\
\text { FAILURE } \\
\text { MODE }\end{array}$} & \multirow{2}{*}{$\begin{array}{l}\text { ASSUMED } \\
\text { CAUSE OF } \\
\text { FAILURE }\end{array}$} & \multirow{2}{*}{$\begin{array}{l}\text { EFFECT } \\
\text { ON MISSION } \\
\text { PERFORMANCE }\end{array}$} & \multirow{2}{*}{$\begin{array}{l}\text { COMPEN- } \\
\text { SATING } \\
\text { PROVISIONS }\end{array}$} & & \multirow{2}{*}{$\begin{array}{l}\text { RISK } \\
\text { PRIOR- } \\
\text { ITY } \\
\text { NO. }\end{array}$} & \multirow{2}{*}{$\begin{array}{l}\text { PROPOSED } \\
\text { COURSE OF } \\
\text { ACTION }\end{array}$} \\
\hline $\begin{array}{l}\text { DES- } \\
\text { CRIP- } \\
\text { TION }\end{array}$ & DETAIL & & & & & $\begin{array}{l}\text { OC } \\
\text { PROBA- } \\
\text { BILITY } \\
\text { OF }\end{array}$ & $\begin{array}{l}\text { CURREN } \\
\text { SEVER- } \\
\text { ITY } \\
\text { OF }\end{array}$ & $\begin{array}{l}\text { CE } \\
\text { DETEC- } \\
\text { TION } \\
\text { OF }\end{array}$ & & \\
\hline \multirow{5}{*}{\multicolumn{2}{|c|}{ 4. INSULATION }} & $\begin{array}{l}\text { 1. CAKING OR SIN- } \\
\text { TERING CAUSING } \\
\text { BLOCKING OF } \\
\text { FOIL COLD } \\
\text { STRAP. }\end{array}$ & $\begin{array}{l}\text { TIME, EXCESSIVE } \\
\text { OPERATING TEMPER- } \\
\text { ATURE OR FOREIGN } \\
\text { MATERIALS. }\end{array}$ & & \multirow[t]{5}{*}{$\begin{array}{l}\text { COMPATIBILITY } \\
\text { TESTING TO DATE } \\
\text { INDICATES NO } \\
\text { PROBLEM AT OP. } \\
\text { ERATING TEMP. } \\
\text { ERATURE. }\end{array}$} & .5 & 5 & 10 & 25 & \multirow[t]{2}{*}{$\begin{array}{l}\text { O.C. PROGRAM } \\
\text { WITH PROPER } \\
\text { INSULATION } \\
\text { PROCESSING }\end{array}$} \\
\hline & & $\begin{array}{l}\text { 2. OUTGASSING OF } \\
\text { WATER VAPOR. }\end{array}$ & $\begin{array}{l}\text { PROPERTY OF INSU- } \\
\text { LATION OR INSUFFIC- } \\
\text { IENT PROCESSING. }\end{array}$ & & & .1 & 5 & 1 & .5 & \\
\hline & & \multirow{2}{*}{$\begin{array}{l}\text { 3. INCREASED } \\
\text { THERMAL CON- } \\
\text { DUCTIVITY } \\
\text { AFTER A PER- } \\
\text { IOD OF OPERA- } \\
\text { TION. }\end{array}$} & $\begin{array}{l}\text { 1. CHARACTERISTIC } \\
\text { OF INSULATION. }\end{array}$ & \multirow{2}{*}{$\begin{array}{l}\text { REDUCED OUTPUT } \\
\text { FROM INCREASED } \\
\text { THERMAL LOSS. }\end{array}$} & & 1 & 2 & 10 & 20 & \multirow[b]{3}{*}{$\begin{array}{l}\text { BLOWN INSUL- } \\
\text { ATION STUDY. }\end{array}$} \\
\hline & & & $\begin{array}{l}\text { 2. CAUSED BY FOREIGN } \\
\text { MATERIAL }\end{array}$ & & & 2 & 1 & 10 & 20 & \\
\hline & & $\begin{array}{l}\text { 4. MISELIGNMENT } \\
\text { AND DISORIEN- } \\
\text { TATION OF } \\
\text { ASSEMBLIES }\end{array}$ & $\begin{array}{l}\text { INSTALLATION OF } \\
\text { INSULATION DISTURBS } \\
\text { ASSEMBLIES }\end{array}$ & & & 2 & 5 & 10 & 100 & \\
\hline \multicolumn{2}{|c|}{$\begin{array}{l}\text { 5. COLD } \\
\text { FRAME }\end{array}$} & $\begin{array}{l}\text { POOR HEAT } \\
\text { TRANSFER. }\end{array}$ & $\begin{array}{l}\text { INADEQUACY OF TIN } \\
\text { PLATING. }\end{array}$ & $\begin{array}{l}\text { INCREASED } \triangle T \text { BE- } \\
\text { TWEEN COLD FRAME } \\
\text { AND HOUSING RE- } \\
\text { DUCING POWER OUT. }\end{array}$ & & 2 & 2 & 1 & 4 & O.C. PROGRAM \\
\hline
\end{tabular}




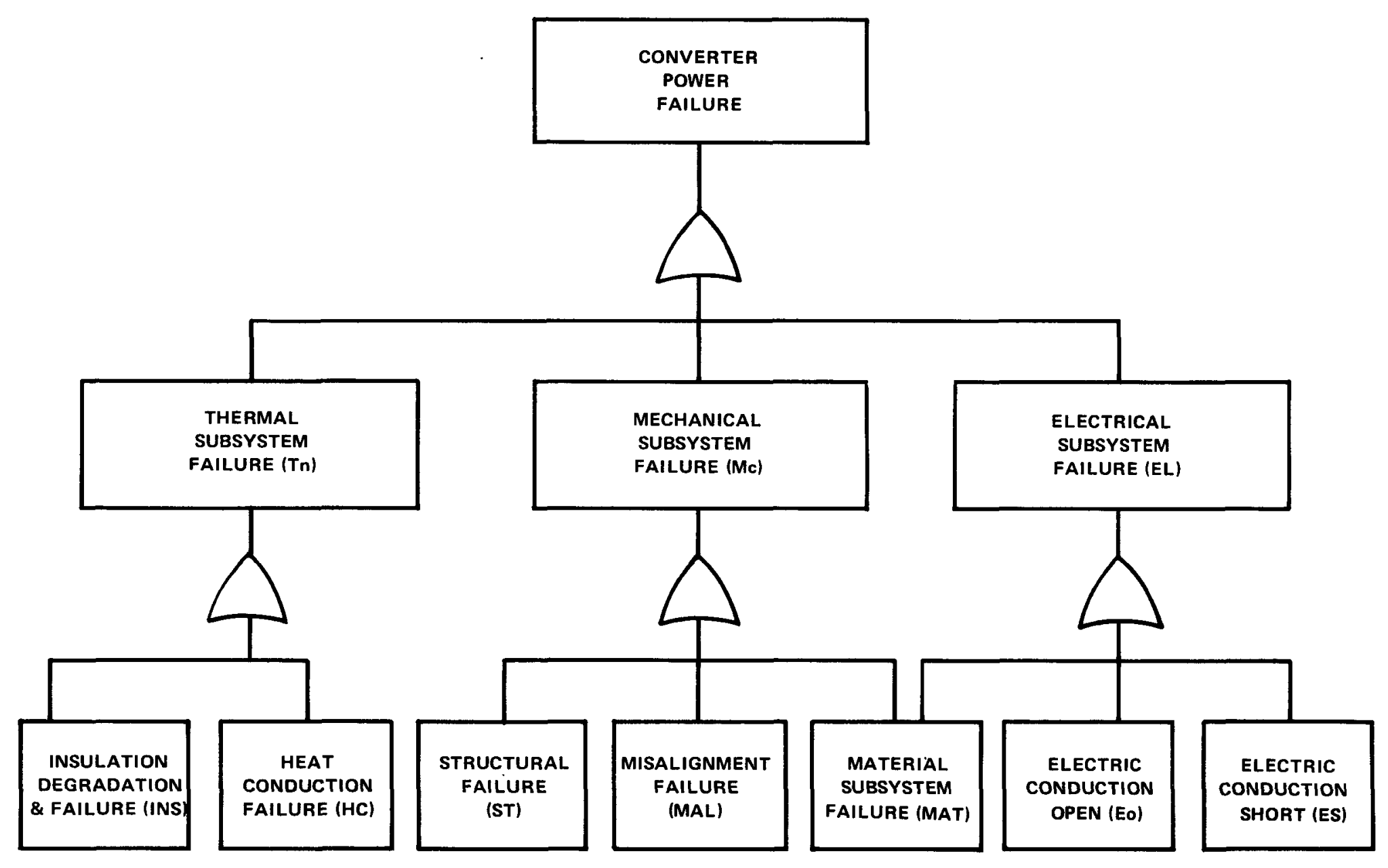

FIGURE 141: FAILURE MODE LOGIC DIAGRAM 


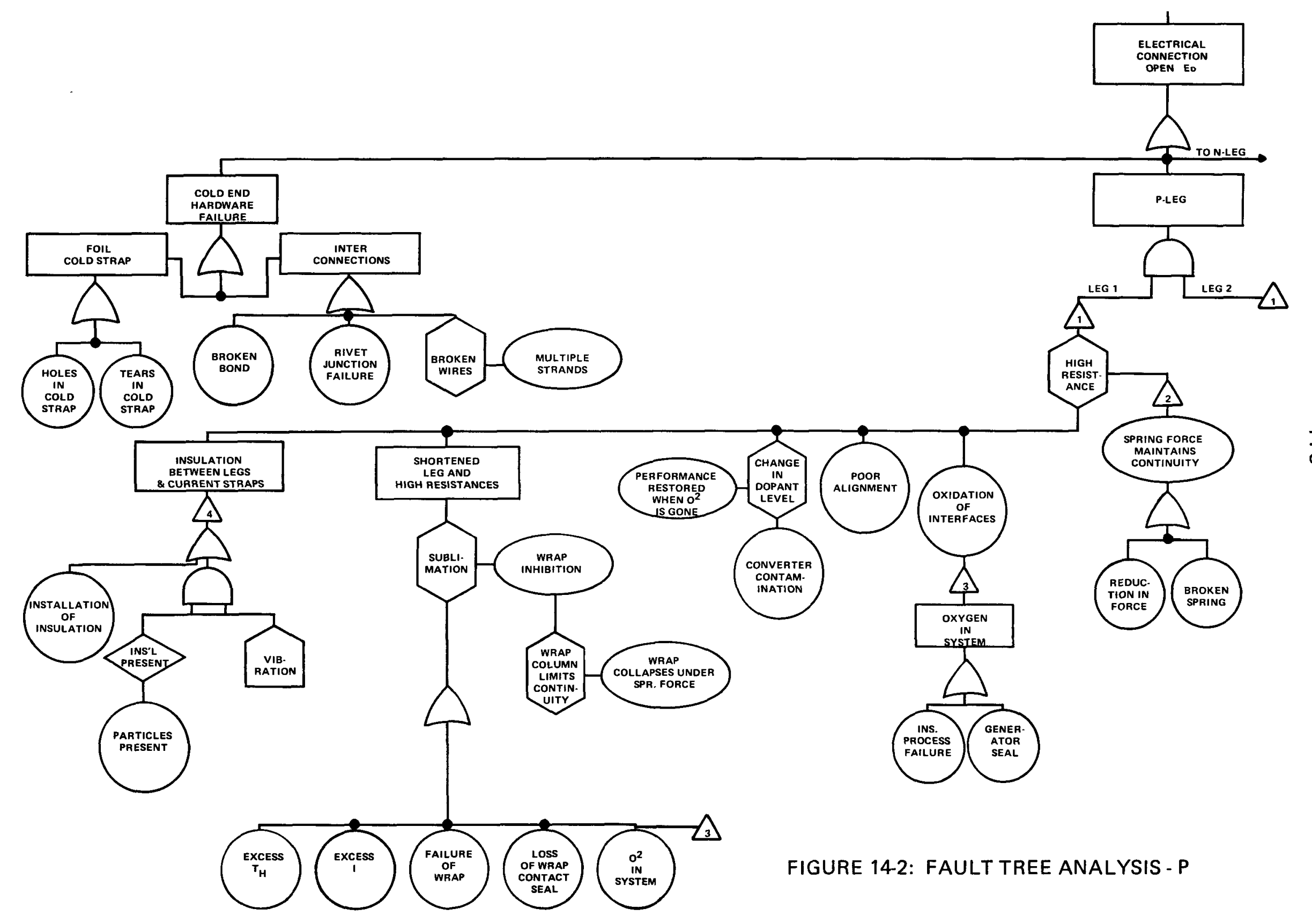




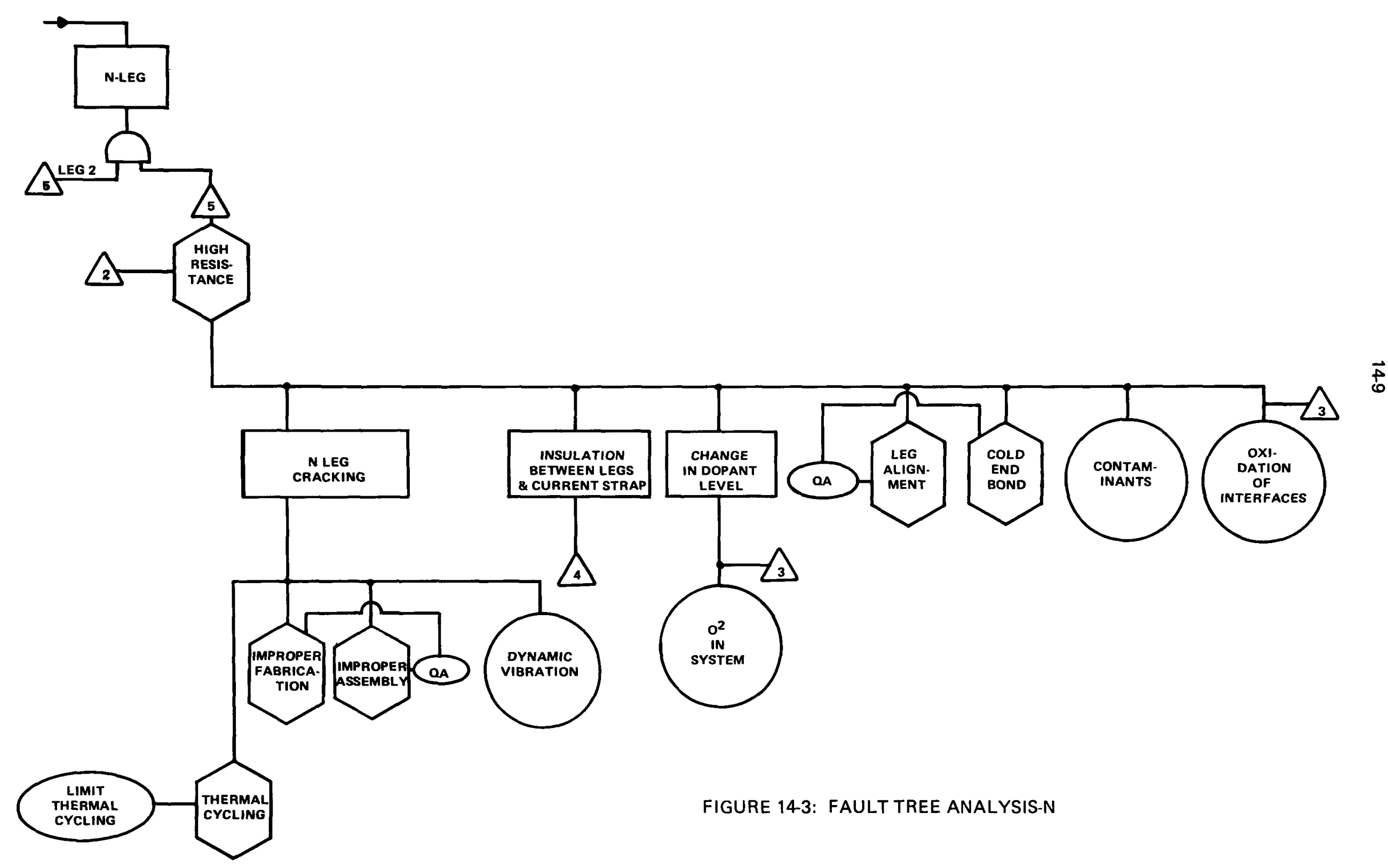

